


\section{$\mathrm{Fl}$ \\ 42 \\ Or 2}

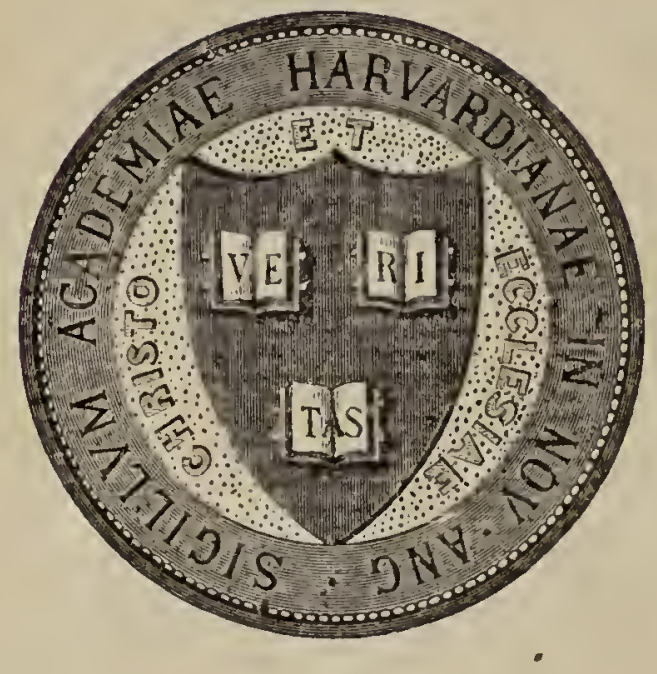

HARVARD UNIVERSITY

L I B R A R Y

OF THE

GRAY HERBARIUM

Received Feb. 17, 1909. 
Sraris. 


$$
x^{4} x^{5}=
$$








\section{Flora Nottinghamiensis,}

- or a

SYSTEMATJC ARRANGEMENT

OF TIIE

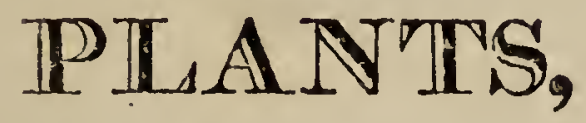

GROWING NATURALLY IN THE COUNTY OF

NOTTINGHAM;

WITH THEIR

LINNEN AND ENGLISH NAMES, GENTRIC AND SPECIFIC CHARACTERS.

IN LATIN AND ENGLISH,

PLACES OF GROWTH,

A N

TIME OF FLOWERING.

\section{By THOMAS ORDOYNO,}

Nurseryman and Seedsman, Newark.

N E W A R K ;

Printed for the Author, by S. and S.RIDGE. AYD SOLD BX B, CROSBY, AND CO. 3TATIONER'S NOURT; LONDON. 
FEB 181909

Heriravenom 
TO

\title{
Mrs. SHERBROOKE,
}

\author{
or \\ $O X T O N$ \\ IN THE COUNTY OF NOTTINGHAM,

\section{THIS VOLUME}

IS, WITH HUMBLE DEFERENCE, INSCRIBED,

As AN

INADEQUATE TESTIMONY OF RESPECT,

FOR HER

ACKNOWLEDGED ATTAINMENTS

IN TH

SCIENCE OF BOTANY.

By her obedient Servant,

Thomas Ordoyno.

NewARK, Alugust 5th, 1807. 



\section{LIST OF SUBSCRIBERS.}

\section{A Dlington, Mr. Joseph, Winkburn.}

Atkin, Mr. John, North Muskham.

Byron, Right Hon. Lord, Nezustead. Bartlett, Rev. Mr. Sioke Field. Bates, Mr. James, Newark.

Becher, Rev. John Thomas, Southwell, 3 copies. Becher, Rev. Sherard, ditto.

Betham Mr. Edward, Grantham

Bennet, Mr. Serlby, Arnold.

Bland, T. Esq. Newark.

Bland, Miss ditto.

Boot, Mr. Ollerton.

Buwman, Mr. Richard, East Relford.

Bravender, Mr. William, Ratcliff.

Bristoe, Rev. William, Southwell.

Brooke, Rev. Joshua, Newark.

Brown, Mr. Edward, North Muskham.

Buck, Dr: Newark.

Burnell, Peter Pegge, Esq. Winkburn:

Burnell, Mrs. Pegge, ditto. 


\section{[ 5 b $]$}

Cartledge, Mr. John, Newark.

Cadness, Mr. John, Gardener, Arrold.

Charlesworth, Rev. John, Ossington.

Cheales, Rev. Wm. White Houses, Retford.

Chorley, - M. D. Doncaster, 2 copies.

Clarke, Mr. George, Scedsman, Newark.

Clarke, Mr. Thoṣ. Kirkby Hardwick.

Coape, Miss Sherbrooke, Oxion.

Cooke, Mr. Robt. Newark, 3 copies.

Crowder, Mr. Wm. Horncasile.

Davies, Rev. J. Trinity College, Cambridge.

Denison, John, Esq. Ossington.

Deeping, Mr. William, Nezuark.

Doughty, Mr. Robt. Southwell.

Dyson, Mr. James, Newark.

Edmundson, Mr. Benj. Newark.

Elstone, Mr. William, ditto.

Falkner, Mr. Thomas, Southwell.

Fletcher, Miss, Newark, 2 copies.

Forster, Mr. Richard, Grimsby.

Forster, Mr. William, Besthorpe.

Fowler, Rcv. Charles, Southwell.

Godfrey, Edw. Sinith, Esq. Newark, 3 copics.

Gibson, Mr. William, Screveton.

Griffin, M. William, Leicester. 


\section{$\left[\begin{array}{ll}6 & 6\end{array}\right]$}

Harrison, Mr. S. Nurseryman, Brompton, London.

Herreman, Mr. James, Newwark.

Hill, Mr. Wm. ditto.

Hole, Mr. John, dillo.

Hutchinson, Mr. Benj. Southwell.

King, Mr. William, Newark.

Leacroft, J. Esq. Southwell.

Lee, Mr. William, Newark.

Martin, Miss, North Muskham.

Mason, Henry, M. D. Relford, 2 copies.

Mason, Mr. Robt. Oxton.

Middleton, William, Esq. Norton Grange.

Midgley, Mr. Williamson, Rollestone.

Mozley, Mr. William, Newark.

Nelson, Rev. Mr. Newark.

Nettleship, Mr. Thomas, ditto.

Ordoyno, Mr. Jacob, Coddington, 3 copies.

Pocklington, Roger, Esq. Winthorpe.

Pocklington, Roger, Esq. junr. ditto.

Padley, Robert, Esq. Burton Foist, near Nottingh.

Palethorpe, Mr. Thomas, Nurseryman, Newark.

Parr, Mr. William, Bingham.

Pearsun, Mr John, junr. Nurseryman, Chilwell.

Pickering, Mr. T. Newark.

Price Nir. Richard, Nottıngham. 


\section{$\left[\begin{array}{ll}7 & \end{array}\right]$}

Rickett, Mr. Joséph, Newwark.

Rippon, Mr. Marmaduke, ditto.

Sherbrooke, Mrs. Oxton.

Short, Miss, Kingsay Hall, near Tuxford.

Shephard, Tuffin Esq. Southwell.

Sandafer, Mr! John, Southwell.

Shephard, Mr. William, Newark.

Shephard, Mr John H. ditto.

Sikes, Mrs. ditto.

Snart, Mr. Charles, ditto.

Sowerby, Mr. James, Mead Place, London.

Statham, Samuel Esq. Arnold.

Sutton, Rev. Richard, Brant Broughton.

Swift, Mr. Willian, Southwell.

Thompson, B. Esq. Arnold.

Thompson, Mr. William, Newark.

Trotter, Mr Stubton.

Whetham, Mrs. Kirklington.

Ward, Mr. H. P. Newark.

Withers, Mr. Joseph, ditto.

Wilkinson, Mr. Gardener, ditto:

Wiggington, Mr. Panks, ditto.

Wilson, Mr. Joseph, Nurseryman, Derby.

Wright, Thomas Esq. Norwood Park.

Wright, Col. Colstone Bassett.

Wood, Mr. Gardener, Burton Foist. 


\section{P R E A C E.}

Full many a flower is born to blush unseco, And waste its sweetness op the desert air....

GrAY.

Botanists have invariably been ac. customed to publish national or provincial Floras, according to the extent of those limits within which their personal researches have been exercised. In no country however, has indigenous Botany 'been prosecutcd with more claborate investigation than in Great Britain. We can adduce the wenerable names of Ray, Dillenins, Hudson, Lightfoot, Withering, Curis, Relhan. 


\section{[ ii $]$}

Sinthorpe, and others; but above all, of Smith, whose English Botany, and Flora Britannica, are, independent of his previous celebrity, sufficient to establish his title to unrivalled pre-eminence.-Even NutringHAMSHIRE has not been destitute of a naturalist, to record the history of her vegetable inhabitants; nearly a century has elapsed, since Deering published his "Catalogue "OF PLANTS NATURALLY GROWING abOUT " NOTtingham;" and although the busy hand of human industry has, in the lapse of time, altered the face of nature, and expelled many of these inoffensive tribes from the habitalions, which they formerly occupied, still they are not extirpated; they are, even at this day, to be discovered, by their diligent votaries, in those sheltered assylums, where cultivation has not invaded the privacy. of their sequestered retreat.-Thither would I conduct your steps, animated by the desire of introducing you to this aboriginal race, many of whom have eluded the observation of Deering, my predecessor, to 


\section{[ iii ]}

whose merits I shall be disposed occasionally to pay that tribute, to which they are deservedly entitled.

The generic and specific characters in Latin are extracted from the Flura Britannica, to which I must on every occasion refer you :: those in English are taken from "W WTHER"InG's Bolanical Arrangement of British. "Plants," a work valuable to all, but inestimable to those who are unacquainted with the Latin language. It would have been casy to have substituted my own tran-. slation, but obvious reasons have induced me to prefer the plan which has been adopted:-With the assistance of these excellent authors, the British Botanist will obtain all the information of which he is solicitous. In their society he must pursue his studies within the house; the Flora.Nottinghamiensis is intended as his companion in the field.As such, it is presumed, that it will be found an acceptable manual to all, whom MEDICINE, AGRICUITURE, or AMUSEMENT, may incite 


\section{[ iv ]}

to the acquirement of an intimate acquaintance with the plants; indigenous to the County of Nottingham, and the situations in which they are to be found. Many of both sexes, have, I am well aware, successfully dedicated their attention to the attainment of similar objects. - From these, I will venture to solicit communications, which, with their permission, I shall gratefully acknowledge in a supplement to the Flors Nottinghamiensis.

Before I conclude, I feel it incumbent upon me to express my gratitude to those, who have honoured this volume with their patronage; to the owners of those lands, upon which I have, at any time, inoffensively. trespassed; to Dr. Buck of Newark, for the liberality with which he has, on all occasions, communicated with the on these subjects, and for the discovery of many rare plants;-to Mr. ORDOYNO of Coddingtont, under whose instruction, I acquired the rudiments of this science; - and more patticu- 


\section{$[\mathrm{v}]$}

larly to the Rev. J. T. Becher of Southiwell, at whose suggestion this work was undertaken; and to whom I stand indebted for the form which this publication now assumes, as well as for that unreserved assistance, which has effected the solution of every difficulty that occurred in the progress of this undertaking.

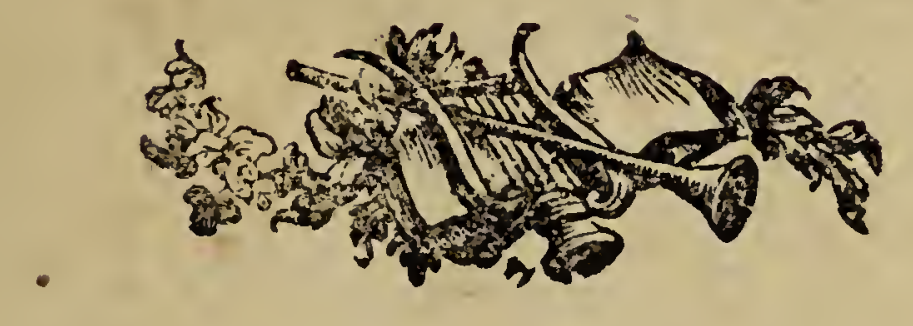




\section{ERRATA ET CORRIGENDA.}

PAGE 93. dele "frequent, Southwell; Newark." and read s" very rare." I have not heard that this plunt has been found in any part of this County, except in the ditches by the side of some sinall gardens at the foot of Nottingham Castle Rock, where two or three plants were discurered, about six jears ago, by the Rev. J. T. Beciser. 


\title{
FLORA
}

\section{NOTTINGHAMIENSIS.}

\author{
- \\ Classis 1 . \\ MONANDRIA.
}

Smith. page 1. Withering. page 1.

\section{Stamen 1. MONOGYNIA.}

Stylus 1.

* Angiosperma.

1 Flowers with famens, and flowers with pistils on the Jame plant.

CHARA. Bacca polysperma. CHARA. MALE. Calyx none.

FEM. Calyx 4 leaves. Summit 3 -cleft. Seed 1. B 
2 MONANDRIA. MONOGYNiA. Chara.

\section{DIGYNIA.}

Styli 2.

CAllttriche, Cal. nullus. Pciala 2. Semina 4. nuda.

CALLITRICHE, Cal, none. Bloss, 2 petals. Capsule 2 -celled.

\section{MONANDRIA. \\ 1. MONOGYNIA.}

CHARA. Smith. page 4. Withering. page 2. Cal. nullus. Cor. nulla. Anthera sessilis. Stylus nullus. Bacca polysperma.

MALE. Calyx none. Anther at the base of the germen.

FEM. Cal. 4-leaved. Summits 5-cleft. Seed 1.

vulgaris. C. inermis, striata, foliis subulatis articulatis.

C. Stems smooth: leaves loothed on the inner side.

COHMON CHARA. 8TONEWORT. STINKING

WATER HORSETAIL. Ditches and pools; in the old grarel pits near Kirklington Mill. A. July. Aug.

hispida. C. sulcata, foliis subulatis articulatis, foliolis verticillatis, aculeis caulinis setaceis deflexis.

B. C. major subcincrea fragilis. Raii Syn.132.

C. tomentosa, Withering. page 2.

C. prickles on the stem, egg-Jhaped.

RTTTLESTONEWORT. Ditches and pools; in the Liaj jits, near Mapperly brick-liilns.

Deering.p. 54 . 


\section{MONANDRIA. MONOGYNIA. Callitriche. 3}

\section{DIGYNIA.}

CALLITRiCHE. Sinitín. 8. Wilhering. 5 .

Cal. nullus. Petala duo. Stignala acuta. Semina quatuor, compressa, nuda, hinc marginato.alatá.

Flores aliquot monoici.

Cal. none. Petals 2. Seeds 4 ; naked, with a membranaceous border on one fide.

Callitriche.
C. verna. Upper leaves sval; not notched at the end.

Withering. 5 .

WATER STARWORT. VERNAL STARGRASS. Ditches, pouds, and very sluw streams; frequent.

April-..-Oct.

B. Callitriche autumnalis,

C. All the leaves ftrap shaped, cloven at the end. Flowers hermaphrodite.

I. NG WATER STARWORT. AUTUMYAL, STARGRASS. Ditches and still waters; frequent. A. Bep.

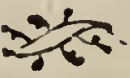

$\mathrm{B} a$ 


\section{Classis $I I$.}

\section{DIANDRIA.}

Smith. 11. Withering. 8.

Stamina 2.

1. MONOGYNIA.

\section{Stylus 1 .}

* Flores inferi, monopetali, regulares.

1 Blossom 1 regular petal; beneath.

LIGUSTRUM. Cor. quadrifida. Bacca tetrasperma

LIGUSTRUM. Bloss. 4-cleft. Berry 4-seeded.

FRAXINUS. Cor. nulla, aut quadripartita. Cap. compressa, disperma.

FRAXINUS. Calyx none; or with 4 divisions. Bloss. none; or of 4 peials. Seed 1 , jpear-shaped.

* Flores interi, monopetali, irregulares, angiospermi. 2 Bloss. irregular. Seeds in a capsule.

VERONICA. Cor. quadripartita, rotata,

VERONICA. Bloss. border with 4 divisions, lower jegment the narrowest. Caps. inversely heart-Jina. ped.

PINGUICULA, Cor, ringens, calcarata. Cal, quinquefidus. 


\section{DIANDRIA. DIGYNIA.}

PINGUICULA. Bloss. gaping, ending in a four. Cal. 5 cleft.

UTRICULARIA. Cor. ringens, calcarata. Cal. diphyllus.

UTRICULARIA. Bloss, gaping, ending in a pur. Cal. 2 leaves.

* * Flores inferi, monopetali, irregulares, gymnos. permi.

3 Bloss. irregular. Seeds naked.

LYCOPUS. Cor. subæqualis. Stam. distantia.

LYCOPUS, Bloss. nearly regular. Stam. wide apart. SALVIA. Cor. ringens. Filamenta transverse pedicellata.

SALVIA. Bloss. gaping. Filaments fixed across a pedicle.

$$
\begin{aligned}
& * * * \text { Fl. superi. } \\
& 4 \text { Flowers fuperior. }
\end{aligned}
$$

CIRCÆA. Cor. dipetala. Cal. diphyllus.

CIRCAA. Cal. 2 leaves. Bloss. 2 petals inwerse?y heart-ghoped.

\section{DIGYNIA. \\ Styli. 2.}

ANTHOXANTHUM. Cal. gluma uniflora, bivalvis. Cor. gluma bivalvis, aristata.

ANTHOXANTHUM. Calyx, husk with one flower; oblong. Bloss. 2. husks; azuned. 


\section{DIANDRIA. \\ - MONOGYNIA.}

LIGUSTRUM. Smith. 12. Withering. 10.

Cor. quadrifida. Bacca superá, bilocularis, tetrasperma.

L. Bloss. 4-cleft. Berry with 2 cells, 2 Jeeds in each cell:

oulgare. L. foliis elliptico-lanceolatis obtusis mucronulatis.

L. Leaves egg-Jhaped, blunt: panicle with 3 divisions.

PRIVET. PRIM. PRINT. Hedges in gravelly soils; not uncommon. South well. Newark. S. Miay, 'tune.

FRAXINUS. Smith. 12. Withering. 57.

Cal. nullus, ant quadripartitus. Cor. nulla, aut quadripartita. Caps. supera, bilocularis, superne foliacea, compressa. Sem. solitaria, pendula.

Flores aliquot fominei.

Cal. none, or with 4 divisions. Bloss. nene, or with 4 petals.

Fem. and hermaphrodile flowers. Pist. 1. Caps. 2-celled, leaf-like upwards, compressed; 1 cell barren. Seeds fpear-Jhaped.

F. Cal. none, or with 4 divisions. Bloss. none, or with 4 petals.

excclsior. F. foliolis serratis, floribus calyce corollaque destitutis.

F leafts serrated: flowers without petals. COMMON ASUI TRE E. Woods abd hedge rows.

T. Ap, May. 
CIRCEA. Sinith. 13. Wilhering. 10.

Cor. dipetala. Cal diplyillus, superus. Caps. bilocularis. Sem solicaria

Bloss. 2 petals. Cal 2 leazed, fuperiour.

C. caule erectn, foliis ovatis denticulatislutelia. opacis pubescentibus.

na.

C. Slem upright: bunines feveral: leaves eggshaped. Linn. fomewhat ferrated: rough wiih haur. Gmell. Leaves egg-Spear-Jhaped, hairs foinewhat Jerrated.

IVNCIIANTER'S IRHT-BHAIDE. COMMON ENCHA ITER's WORr. Woods; moist hedgebottoms; in shady lines: not umcomimon. Southwell: Haliam Hills: ans in the inllowing noots; Hperston, Oxion, Colwict, Wernham, Kirklington.

$$
\text { P. June, July. }
$$

VERONIC.A. Smith. 15. Withering. 11.

Cor. quadrifide, rotata, lacin!a infima angustiore. Caps. supera, bilocularis.

Blossom border 4-clefi; the lower fegment nar. rowest. Capsule 2-celled; notched at the end.

* Spicatæ.

1 Flowers in spikes.

V. spicis lateralibus pedunculatis, foliis op. officinapositis scabris, caule procumbente. lis.

V. Spikes on lateral fruit flalks: leaves oppofite : Atem trailing.

COMMON SPEEDWELI. MAI.E SPEFDWELL. Fl.UliLLIN. On barren sandy ground, heatbs, lanes, and moors; Coddington and Langford, near ' ewark: Edingley gravel-pits; Kirkby; Broxtow Woods.

P. May-augist. 


\section{DIANDRIA. MONOGYNIA. Verunica.}

* * Corymboso-racemosæ.

2 Flowers in a bunch like corymbus.

serpylli. $V$. racemo terminali subspicato, foliis ovatis folia. subcrenatis trinerviis glabris, capsula obcordata stylo breviore.

V. Bunch terminating, fomewhat spike-like: leaves egg. Shaped, fmooth, fcolloped, $3 \cdot f-$ bred. Siamens hardly longer than the blosfom.

SMOOTH SPFEDWELL. PAUL'S BETONY. MEAdows and pastures; not unconmon. Southwell, Newark.

P. Niay, Juue.

Becca-V. racemis lateralibus, foliis ellipticis planis, bunga. caule repente.

V. Bunches lateral: leaves ego flaped, flat: Alem creeping.

BROOKLIME. Slow shallow streams; and near springs that seldum fiecze. Suuthwell; Newark.

$$
\text { l. June, July. }
$$

Anagallis. V. racemis lateralibus oppositis, foliis lan. ceolatis serratis, caule erecto.

V. Bunches lateral; leaves Jpear-Jhaped, fer. rated: ftem upright.

WATER SPEEDWELL. LONG-LEAVED BROOKLIME. "fow streams and shallow ponds; near the bridge on the road from Southwell to Upton; in Fiskerton lane; in a ditch near Bucklow's peppermint garden, at soutbivell.

P. June---Augast.

seutellata. V. racemis lateralibus alternis : pedicellis divaricatis, folin linearibus denticulatis.

V. Bunches lateral; thinly fet wilh flowers, 


\section{DIANDRIA. MONOGYNIA. Veronica. 9}

wide spreading, alternate: little fruit-stalhs pendant: leaves very entire, strap-shaped.

NARROW LEAVED SPEEDWELL. MARSH

SPEEDW ELL. In low marshes, on foor boggy soils;

Oxton Bottoms; in a low swampy close, by the road side, near Papplewick water-mill ; on Edingley moors; Farnsfield carr; ditches on Coddington moor.

$$
\text { P. June---August. }
$$

V. racemis lateralibus, foliis ovatis sessilibus Chance. rugosis inciso-serratis, caule bifariam piloso. drys.

V. Bunches lateral; leaves egg-Shaped, futing, wrinkled, toothed; stem wien a opposile rows of hairs.

WHD GERMANDER. GFRMANDER SPERD. WlELL Pasturce and sifies of hedges; dry bunks: common, Southwell; Newark. M. Mi.y.

$$
\begin{aligned}
& \text { * * Floribus solitaris. } \\
& 3 \text { Fruil-jalks with one flower. }
\end{aligned}
$$

V. floribus solitariis, foliis ovat is inciso serra-agrestis. tis pedunculo brevioribus, caulibus procumbentibus, seminibus urceolatis.

$V$. Flowers solitary: leaves heart-ghaped, on leaf falks, shorter than the fruit-ftalks.

GERMANDER CHICKWIED. PROCUMBENT SPEEIDWEL! Pastures and ploughed fields; comnon: Southwell; Newark.

A. $\Delta$ pril.

V. Floribus solitariis, foliis ovalis inciso-ser-arvensis. ratis: floralibus lanceolatis pedunculo longioribus, caule erecto.

V. Splke terminating : leaves heart-Jhaped, fitting: floral leaves Jpear-Shaped, longer than the flowers.

WALL SPEEDWELL. SPFEDWWLL CHICKIV EED. On old walls; amongst rubbish and fallow fields: common.

A. Mag. 
10 DIANDRIA. MONOGYNIA. Pinguicula.

hederce- V. floribus solitariis, foliis cordatis planis folia. quinquelobis, laciniis calycinis cordatis, seminibus urceolatis.

V. Flowers folitary: leaves heart-fhaped, flat, 5.lobed.

SMALT HENBIT. IVY CHICKWEDD. ITY

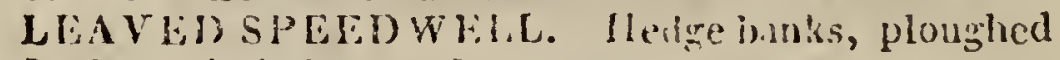
fields, and kichen gardens : rery common.

A. A pril-..-Sept

PINGUICULA. Smith. 26. Withering. 18.

Cor. ringens, calcarata. Cal. bilahiatus, quinquefidus. Caps. supera, unilocularis.

Bloss. gaping, ending in a Jpur. Cal. 2.lip. ped, 5-clefi. Capsule a cell.

vulgaris. P. nectario cylindraceo, acuto longitudine petali, capsula ovata.

P. Nectary cylindrical, as long as the petal.

COMMON BUTTERWORT. YORKSHIRISANI-

CLE. On bogs, and low marshy grounds. In a close at Halam beck, near Southriell; on Erlingley moors, Oxion siews, and Bisford scottum. P. May, June.

UTRICULARIA. Smith. 28 . Withering. 19.

Cor. ringens, calcarata. Cal. diphyllus, oqua. lis: Caps. supera, unilocular is:

Bloss. gaping, cnding in a fpur. Calyx 2 leaves, equal. Capsule 1 cell.

vulgaris. U. nectario conico, scapo paucifloro.

U: Nectary conicul; Atalk with feulflowers:

HOODED WATER MILEOLL. GREATER BLAD.

DER SNOUT. Wet ditches and stagnant waters. somewhat rare. In old gravel pits, near Kirklington Mill; and in the lake at Thurgarton P'riory, the seat of 3. (i. Coopier, Esq.; at the boitom cad of Mruskham lilee!, near Newark. P. July. 


\section{DIAN DRIA. MONOGYNIA. F, Yoopus is}

U. nectario carinato brevissimo obtuso.

minor.

U. Nectary keel-jhaped.

LESSER BLADDIR SNOUT. Ditches and muddy ponds. rare. Eddingley noor. P. July.

LYCOPUS. Smith. 29. Withering. 20.

Cor. quadrifida: lacinia unica emarginata. Stam. distantid, Sem. quatuor, nuda, retusa:

Bloss. 4.cleft; 1. Jegment notched at the end. Stamens diftant: Seeds 4 , blunt.

L. foliis sinuato-serratis:

L. Leaves indented, and ferrated:

europaus.

WATER HOREIIOUND. GYPSIE. WORT. Sandy ground, and on banks of streams and ponds; ditches; banks of the fireet, at Southwell; ditches near the road from Newark to Kelham, and towards A verham meadow; Edingley Moor. P. July---Sept.

SALVIA. Smith. 30. Withering. 21.

Cor. inæqualis: Filamenta transverse pedicello affixa. Sem. quatuor, nuda.

Bloss, gaping. Filaments fixed tranfverfely to a little fooi ftalk:

S. foliis serratis sinuatis læviusculis, corrol. verbelis calyce angustioribus:

naca.

S. leaves indented, ferrated, fmoothifh, bloffom more fender than the calyx.

WILD FNGLISH CLARY: MEADOW SAGK. MEdows and pastures, and hedge banks hy road sides; about Nottingham Castle; hedge botioms in Farndon lane, wear the Spring Housc, Newark. P. Juue-mOct. 
Is DIANDRIA. MONOGYNIA. Anthoxanthum.

\section{DIGYNIA.}

ANTHOXANTHUM. Smith. 31. With. 58.

Cal. gluma bivulvis, uniflura, Cor. gluma bivulvis, aristata. Semen unicum:

Cal. Hufk of 2 valves, and 1 flower. Bloss. hufk 2 valves, tapering to a point. Seed 1.

odora-A. spica orato-oblonga, flosculis subpeduntum. culatis arista longioribus:

A: Spike oblong-egg-fhaped: florets longer than the awns, fupported on fhort fruit Aalks.

SWEET SCENTED VERNAL GRASS. SPRING GRASS. Meadows and pastures; common.

P. May, June.

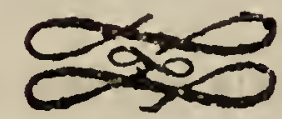




\section{Classis III. \\ TRIANDRIA.}

Sinith. 32. Withering. 60.

Stamina 3 . MONOGYNIA.

Stylus 1.

* Flores superi.

1 Flowers superior.

VALERIANA. Cor. quinquefida, basi gibba. Sem. 1: VALERIANA. Bloss. 5-cleft; bulging at the base. Seed 1 .

CROCUS. Cor. sexpartita, æqualis. Stigmata conro. luta.

CROCUS. Bloss. refembling 6 petals, upright, epen: Summits rolled in a Spiral; coloured.

IRIS. Cor sexpartita, petalis alternis reflexis. Stigmata petaliformia.

IRIS. Bloss, with 6 divifions; 3 ouler fegments refrected. Suminits like petals.

** Flores inferi, glumacei. Semen unicum.

2 Flowers with values like gra/ses, and hu/k.like calyx es. Hermaphrodile.

C 
SCHOENUS. Gluma paleacex, congestx; exteriores steriles. Sem. subrotundum.

SCHCENUS. Bloss. none. Cal. chaffy fales, in bun. dles. Seed roundish: (lower fcales barren. Scop.) SCIRPUS. Glume palcacex, undique imbricatæ. SCIRPUS. Bloss. none. Cal. chaffy fales, tiled. Seed naked or woolly: 3-cornered: (Hairs short: er than the Calyx. HALLER. All the siales fer. tile. ScOP.)

ERIOPHORUM. Gluma palcacex, undique imbricatæ. Sem. lana longissima cinctum.

ERIOPHORUM. Bloss. none. Cal chieffy fcales, tiled. Seeds woolly'. (Hairs longer than the calyx. HAL.)

NARDUS. Cal. nullus. Cor. Giuma bivalvis.

NARDUS. Bloss. 2 values. Cal. none. Seed cover ed.

\section{DIGYNIA.}

\section{Styli 2 .}

* Calyces uniflori, ragi.

1 Grasses. Flowers siattered; 1 in each calyx.

ALOPECURUS. Cal. bivalvis, Cor. univalvis, apice simplici.

ALOPECURUS. Cal. 2 values: Bloss. 1 value, undivided at the end. Nectary none. 
PHLELM. Cal. bivalyis, truncatus, acuminatus, sessilis.

PILEUM. Cal. 2 values; lopped, dagger-puinted siting.

AGROSTIS. Cal. bivalvis; valvis acutis, corolla brevioribus. Stigmata plumosa.

AGROSTIS. Cal. \& valves: valies acute, fhorter than the blofom: (in all the Englesh species longer.)

DACTYLIS. Cal. bivalvis, compressus; valva majori carinata.

DACTYLIS. Cal. 2 valves: valves concave, keeled. * Calyces biflori, vagi.

2 GRAsses. Flowers scattered; 2 in each calyx. AIRA. Cal. bivalvis. Flosculi absque rudimento interjecto.

AIRA. Florets, all hermaphrodite, without the rudimeni of a third. Cal. 2 valves.

MELICA. Cal. bivalvis, sub-biflorus; rudimento tertii fosculi interjecto.

MELICA. Florets, all hermaphrodite. Cal. 2 valies. Nectary of 1 leaf, flefhy.

HOLCUS. Cal. bivalvis. Cor. aristata. Flosculo altero masculo, apetalo.

HOLCUS. Flowers hermaphrodite and male: Cal. hufk 2 valves, with 1 to 3 florets.

M. Bloss, awned.

F. Bloss. awnless 1. Seed 1. * * Calyces multiflori, vagi.

raAsses. Flowers fcallered, fevera lin each calyx. C 2 
BRIZA. Cal. bivalvis. Cor ventricosa, valvis cordatis, obtusis. Semen corollze adnatum.

BRIZA. Cal. 2 valves. Bloss. heart-/haped, values blunt, bellying.

POA. Cal. bivalvis. Cor. valvis ovatis, acutiusculis, muticis.

POA. Cal. 2 values. Bloss. egg-Jhaped, valves Sharpifh.

FESTUCA. Cal. bivalvis. Sficula oblonga, teretiuscula; glumis acuminatis.

FESTUCA. Cal. 2 valves. Bloss. oblong : values Jharp-pointed.

BROMUS. Cal. hivalvis. Spicula oblonga; glumis sub apice aristatis, inceriore ciliata.

BROMUS. Cal 2 valves. Bluss. oblong; outervalue with an awn fixed below the point.

AVENA. Cal. bivaivis. Cor. gluma teretiuscula, dorso aristata. Arifa contorta.

AVENA. Ca!. 2 valves. Bloss. oblong; valves with a jointed awn upon the back.

ARUNDO. Cal. bivalvis. Flosculi lana persistente cincti.

ARUNDO. Cal. 2 values. Bloss. awnless, woolly at the baje.

* * * Spicati, receptaculo con mu ni scrobiculato.

4. Grass Es. Flowers forming a spike, on a long and slender receptacle.

LOLIUM. Cal. monophyllus, fixus, multiflorus.

LOLIUM. Involucrum 1 leaf, containing 1 manyflowered Spiket. 
TRITICUM. Cal: bivalvis, solitarius, multiflorus. Rachis dentata.

TRITICUM. Cal. containing many florets.

CYNOSURUS. Cal. bivalvis, solitarius, multiflorus. Receptaculum proprium unilaterale, foliaceum.

CYNOSURUS. Cal. 2 values, containing many flowers. Valves frap-Shaped, tapering 10 a point, equal. Nectary of 2 leaves.

HORDEUM. Cal. bivalvis, ternus, uniflorus.

HORDEUM. Involucrum of 6 leaves, containing 3 florets. Flowers simple.

\section{TRIGYNIA.}

Styli 3 .

MONTIA. Cal. Ciphyllus. Cor. monopetala. Caps. trivalvic, trisperma.

MONTIA. Bloss. 1 petal. Cal. 2 leaves.

\section{TRIANDRIA. \\ i MONOGYNIA.}

VALERIANA. Smith. 37. Withering. 65.

Cal. nullus. Cor. monopetala, basi hinc gibba, supera. Semen 1.

Cal, none. Bloss. 1 petal, fuperior, ; bulging on one side at the base. Seed 1, or else a 3 -celled. capsule.

c 3 
dioica. V. fluribus triandris dioicis, foliis radicalibus ovatis; caulinis pinnatis.

V. Stameniferous, and pifilliferous flowers on different plants; leaves winged; leafits very entire: (somewhat serrated.) Stameniferous plants; with imperfect pistils.

SMALL, or MARSH VALERIAN. In moist meatows and marshes; not uncommon. Parks at Soutlowell; Oxton Bottoms; Basford Scottum. P. May, June.

offici- V. floribus triandris, foliis omnibus pinnatis : nalis. foliolis lanceolatis subuniformibus.

$V$. Leaves all winged and toothed.

GREAT WILD VALERIAN. Hedyes, woods, and marshes : common. Parks at Southwell; Halam Bottoms; Edingley Hill.

P. June.

Locufta. V. floribus triandris, caule dichotomo, foliis lineari-lingulatis obtusis.

V. Stem forked; leaves Arap-shaped, very entire.

CORN SALLAD. LAMB'S LETTUCE. Panks and corn fields." Southwell; Newark ; Manstield; Nottingham.

A. April.

CROCUS. Smith. 39. Withering. 69 .

Cor. sexpartita, qualis, supera, tubo longissimo. Stigmata convoluta, erosa. Spatha univalvis, radicalis.

Bloss. with 6 equal divisions: Summits coiled.

vernus $C$. stigmate incluso trifido: lobis cuneiformibus incisis.

C. Sheath of one leaf radical; tube of the corolla very long : stigma, in three hort wedgeShaped lobes, within the flower. ENGLISH Butany. 344. 
SIRING, or GARDEV CROCUS. In meadows: rery rare. In Nottinglam Meadows; plentifully. In the Frora Bnitra vici, Dr. Smitu acknowledges his baving received this plant from Mrs. SHLRнноOKE, of Oxton.

P. A pril.

C. stigmate incluso trifido: lobis multifido- nudilaciniatis penicilliformibus, flore aphyllo. florus.

C. Sheath of one leaf, radical: tube of the corobla very long, leafle/s; ftigma, in three deeply laciniated Jeginents, enclosed within the flower. ENGLISH BOTANY. 491.

XAKED FIOWFRFD CROCUS. In meadows; very raie. He'wcen Nottinghim lastle and the Trent. The

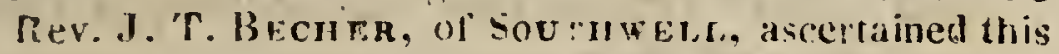
platt to be a distinct species. and it wis inmediately adluntted as such by Dr. sintra. Tlie fact, howcrer, lats since been indisputably confirmed by $\mathrm{Mr}$. Ozboy yo, of Conbin gerox, who has rased both this and the precerling species from seeals. For more han a century these heautiful plants have enamelled the Nottingham ileadoiv, and the Corchicun Comune, of Decring, proves, according to Mr. BrCHER's sllggestion, 10 be our Chocu NuBfluxus. P. Oct.

IRIS. Smith . 41. Withering. 69.

Cor. sexpartita, supera; petalis alternis reflexis. Sitigmala petalifornia:

Bloss. with 6 divifrons, unequal, every other jegment bent back as if jointed. Summits petal-like, 2-lipped, edges at the base turned in:

I. corollis imberbibus : petalis interioribus stig- Pfeuda. mate minoribus, foliis ensiformibus. corus.

I. Every other segment of the blofom smaller than the Jummit. 
YELLOW IRIS. WATER FLOWFR DE LUCE. Banks of rivers; marshes and wet meadows. A verham Meadow; Newark: Osmanthorpe; Southwell; Basford Scottum; Nottinghan Meadow.

P. July.

SCHCENUS. Smith. 42, Wilhering. 79.

Gluma paleacex, congest $x$, exteriores steriles. Cor. nulla. Semen unicum, subrotundum, inter glumas:

Husks chaff-like, of 1 valve, crowded. Bloss. none. Seed 1; roundifh, withrn the hufks.

nigri- S. culmo tereti nudo, capitulo ovato, involucans. cri diphylli valvula altera subulata longiore,

S. Straw cylindrical, naked: spike an egg. Shaped head: involucrum two leaved, i value, awl-ghaped, long.

BLACK BOG RUSH. Bogs and marshes. Fdingley Moors.

P. Jume.

com- S. culmo teretiusculo nudo, spica disticha pressus. involucro monophyllo breviore; spiculis mulcifloris, foliis planis.

S. Straw roundifh, but tending to 3-cornered: naked: Jpikets in 2 oppofice rows. Involucrum 1 leaf: florels with 1 husk.

COMPRESSED BOG RUSH. Turf bogs; not common. In the Park's at Southwell. P. July.

SCIRPUS. Smith. 48. Withering. 73 .

Glume paleacex, undique imbricatx. Cor. nulla. Semen unicum.

Husk chaff-like, tiled on every fide. Bloss, none. Seed 1, 3-cornered, ofien woolly: Hairs Shorter than the spike. 
TRIANDRIA MONOGYNIA. Eriophorum. 21

* Spica unica.
1 Spike fingle.

S. culmo tereti basi vaginato, spica subovali paluftris terminali, glumis a cutis, radice repente.

S. Straw cylindrical, naked: Spike nearly eggShaped, terminating:

MARSH CREEPING CLUB RUSH. Banks of rivers and ditches; frequent. Edingley Noors; Oxton Bottoms.

P. July.

* * Culmo tereti polystachyo.

2 Spikes jeveral: Straw cylindrical.

S. culmo tereti nudo, panicula cymosa decom- lacusposita terminali, spiculis ovatis.

tris.

S. Straw cylindrical, naked: Jpikes feveral, egg Jhaped, on fruit ftalks, terminating. LiN N. Calyx fringed, 3-cleft: middle fegment awl-jhaped.

BULL RUSH. Rivers, pools, fens. Banks of the Trent. P. fuly, August.

ERIOPHORUM. S mith. 58. Withering. 71 . Glume paleaceæ, undiquæ imbricatæ. Cor. nulla. ¿emen unicum, lana longissima cinctuin.

Husks like chaff, tiled on every.fide. Bloss. none. Seeds cncompafjed by very long wool. like hairs.

E. culmisterctibus, foliis canaliculatis apice angustriquetris, spicis pedunculatis. tifoluum.

E. Straw cylindrical: leaves channelled and 3-cornered: Jpikes on fruit-flalks. 
2. TRIANDRIA. MONOGYNIA. Nardus.

CORTON GPASS. MOOR GLASS. Marshes and boss; not uncommnn. Oxton Bottoms; Farnsfield Carr; Edingiey Moors; Marshes about Minsficlu!; Gimston Hoors; Basford Sco:tum. P. June.

NARDUS. Smith. 61. With. 71.

Caly'x nullus. Cor. gluma bivalvis.

Calyx none. Bloss. values. Nectary none.

fricta. N. spica setacea recta secunda.

N. Spike flender, fraight; the florets pointing in one direction.

MAT. GR ASS. Heaths and Marshes. Sherwood Forest near Mansfield; Edingley Moor; not common.

P. June---A ugust.

\section{DIGYNIA.}

PHLEUM. Smith. 68. With, 117.

Cal. bivalvis, truncatus, acuminatus, sessilis, uniflorus, corollain includens.

Cal. 2-valved, fitting, Arap Shaped, lopped, ending in 2 dagger points, inclofing the bloffom.

pratense. P. spica cylindrica longissima, glumis dorso ciliat is arista longioribus.

P. Spike cylindrical, very long: caly'x fringed, and awned: Jtraw uprzght.

COMMON CAT'S-TAIL. THOTHY GRASS. Pag tures; comiuon. 
ALOPECURUS. Sinith.72. Withering. 119. Cal bivalvis uniflorus. Cor. univalvis,. Cal. 2.valved. Bloss. 1 value. Nectary none. A. culmo erecto lavi, spica sublobata, glumis praten. calycinis villosis basi connatis. A. piked fraw, upright: calyx hairy; bloßfom awned.

MHADOW FOXTAIL. FOXTAIL GRASS. Meadows snd pastures : common.

P. May.

A. culmo erecto scabriusculo, spica simplicis-agreftis sina attenuatd, glumis nudiusculis basi connatis carina dilatatis.

A. Spihed fraw upright: calyx not hairy; its hufes unted at the base.

SHEXDER FOX TALL GRASS. Comields and rod sildes.

P. May.

A. cumo adscendente geniculato, spica sub-genicu
bbata cylindrica, ghumis retusis pilosis. Tatus.

A. 'piked fraw knetojointed.

FInATING FOX TAL GRASS. Naring meatoms; "ommon."

P. dugtis!.

AGROSTIS. Smith.7\%. With 124.

Cal. bivalvis, unitlonus: vairulis acutis, Cor: bivalvis, inaqualis, calyco major. Stigmata plumosa:

Cailyx 1-flowered, a-lulled, fpear-fraped, acute, generally rough on the heel: longer than the bloffom. Bluss. 2 alues. Summits hairy. 
21 TRIANDRIA. DIGYNIA. Agrostis.

* Aristatæ.

1. With awns.

canina. A: calycibus ovatis coloratis, corolla nuda: arista dorsali incurva, culmis prostratis sub. ramosis.

A: Calyx valves nesily equal. Blossom val'es very unequal: awn jointed, twice the length of the blofom, fixed juft below its middle.

BROWN BENT GRASS. Neatlows and moist pastires.

A. June.

* * Mu icæ.

2. Without az'ns:

vulgaris. A. panicula patente: ramulis divaricatis capillaribus, calycibus xqualibus, petalo interiore duplo breviore retuso.

A. Panicle fpreading, branches bare at the bafe: florets numerous: calyx inner valie finooth; outer ferrulated upwards: blossom inner value but half the fize of the outer; deciduous.

FINE BEYT CIRASS. Mendors, pastures and field sides; common. Oxton road side.

P. July.

floolni- A: panicula coarctata, culmo rnoso repente, fera. floribus congestis, calycibus aqualibus lan. ceolatis pubercentibus.

A. Panicle compact, branches fliff, fhort, denfe'y crouded with florets at the bafe: calyx inner value finooik, ouicr only jerrulated upivards.

CREIPING BENT GRASS. Moist meadows and pas. tures.

P. July, Aurust, 
A. panicula laxa, culmo repente, calycibus alba. æqualibus lanceolatis nitidis carina scabris.

A. Panicle large, $\int$ preading: calyx, both values ferrulated: fraw trailing.

MARSH BENT-GRASS. Wet ditches, bogs, and marshes.

P. July.

AIRA. Smith. 83. With. 135.

Cal. bivalvis, biflorus. Cor. bivalvis. Flosculi absque interjecto rudimento.

Cal. 2 valves; a-flowered: without any intervening. fubftance between the florets.

* Muticæ.

1 Florets awnles:

A. panicula patente, floribus muticis lævibus aquatica obtusis calyce longioribus, foliis planis.

A. Panicle expanding: florets without aions, finooth, longer than the calyx; leaves flat.

WATER HAIR-GRASS. Margins of pools and rivere. Ditches in Nottingham Meadow; Edingley Moor.

P. June.

\section{* Aristatz.}

2 Florets awned.

A. follis planis, panicula patente, petalis aris-cospitatis basi villosis: arista recta brevi. tosa.

A. Leaves flat: panicle expandiug: petals woolly, and "awned at the bafe: : awn ftraight, Mrort.

TURFY UAIR-GRASS. In möist meadoms and roods; freguent. P. Junc, July. 


\section{TRIANDRIA. DIGYNIA. Holcus:}

flexuofa. A. foliis setaceis, culmo subnudo, panicula patente trichotoma, pedunculis flexuosis, aristas geniculatis.

A. Leaves like brifles: Araws almoft naked: panicles diverging: fruit./lalks zig-zag.

WAVED MOUNTAIN MAIR-GRASS. Deaths ard woods; Mansfield Forest.

P Juty.

pracox. A. foliis setaceis: vaginis angulatis, floribus paniculato-spicatis, flosculis sessilibus basi nudis dorso aristatis.

A. Leaves like brifles: Theaths fmooth, angular with furrows; panicle Jpuke-like: au'n taller than the calyx.

EARLY HAJR.GRASS. Dry commons. Rinworth Forest.

A. May, June.

caryo- A. foliis setaceis, panicula trichotoma divariphyllea. cata, flosculis sessilibus, arista geniculata dorsali.

A. Leaves like brifiles: Sheathes finoothish, furrowed: panicle wide-jpreading when ripe; awns taller than the calyx.

SILVER IIAIR-GRASS. Senty pastures. A. July. HOLCUS. Smith. 88. With. 13 s.

Cal. bivalvis, bilorus: flosculo altero masculino. Cor. bivalvis; exteriori aristata.

Florets hermaphrodite and male. Cal. hijh 2 values, with 1 to 3 florets.

HERMAPHR. Awn twice the length of the blof. fom.

MALE. Awn as long as the bloffom.

analus. H. glnmis villosis, flosculo hermaphroditico mutico, masculo arista arcuato-recurya. 
H. Hufks 2-flowered, woolly; hermaphrodite floret ainnless: male floret with a bent awn, inclofed in the caiyx.

MEADOW SOLT-GRAs?. Mearows and pushures; corumon. L. June, July.

H. glumis subxqualibus nudiusculis, flosculo mollis, hermaphroditico inferiore mutico, masculo arista geniculata, radice repente.

H. Roots creeping; joints woolly: awn protruding out of the calyx. Curt.

CREEPING SOET-GRASS. Corn fields and woods. P. July, August.

H. glumis inæqualibus glabris, flosculo her-avenamaphroditico superiore submutico, masculo ceus. arista geniculata refracta, radice nodosa:

H. Panicled: calyx 2-flowered: male floret awned: hermaphrodite flower fometzmes awnlefs.

Avena elatior. Sp. Pl. 117. With. 163 .

OAT-LIKI: SOFT-GRASS. Meadows, pastures, and road sides.

P. June, Ju!y.

MELICA. Smith. 91. Withering. 138.

Cal. bivalvis, sub-biflorus: rudimentum tertii floris inter flosculos. Cor. bivalvis.

Cal. 2-valved, 2-flowered, with a little subfance, on a pedicle, betwixt the florets. Nec. tary 1 leaf. Stamens dilated at the bafe:

M. petalis imberbibus, panicula secunda ra- uniflo.' mosa, floribus erectis, calyce unifloro:

ra.

M. Panicle thinly fet: calyx with a florets, one hermaphrodite, the cther neutral.

D 2 
WOOD MELIC-GRASs. Woods and hedges. Combes Wood; Epcrstone Thickets; borders of Broxtow Woods. P. May, June.

carulea. M. petalis acutis imberbibus, panicula coarctata, floribus erectis cylindricis.

M. Panicle compact: flowers cylindrical; Araw without knots.

Aira cærulea. Linn.

PURPLE MELIC-GRASS. Boggy meadows. Edingley Moors.

P. August.

POA. Smith. 95. Withering. 1 条.

Cal. bivalvis. multiflorus. 'picuía basi rotundata. Cor bivalvis, valvulis ovatis, acutius. culis, muticis.

Cal. 2-valved. many-flowered. Spikets eggShaped. Valves Jhinny at the edge, raiher acule.

aquatica. $\mathrm{P}$. panicula erecta ramosa laxa, spiculis sexfloris linearibus, flosculis obtusis septemnerviis,

P. Panicle Spreading: Spikets frap-Shaped, 6-flowered.

RTED MEADOW-GRASS. Marshes and banks of rivers.

P. July.

fluitans. P. panicula ramosa divaricata, spiculis adpressis teretibus multifloris, flosculis obtusis septemnerviis basi duplicato-nervosis.

P. Panicle branched, upright: Spikets nearly fitting; cylindrical, awnless.

Festuca fluitans. With. 156 .

ILOTE MEADOW-GRASS. Wet ditches and pond.

P. June. 
P. panicula lanceolata disticho-secunda co-rigida. arctata glabra; rachi marginata, spiculis septemfloris, flosculis teretibus enervibus.

P: Punicle Spear-fhaped, Somewhat branched: branches alternate, pointing one way: frnitftalk bordered.

1IART) MEADOW-TRASs. Stony places and walls. Notringhan Castle; Bulwell Lime-kilus. A.June.

P. panicula secunda coarctata, culmo adscen. comdenie compresso, flosculis angulosis basi pressa. villo conplicato connexis.

P. Panicle compact: Araw flanting, compresséd.

JU-AT-STAIKED MEA DOW-GRASS. Walls, honse tops, and dry pláces. Southwell Parks. P. July, Aug.

$P$. panicula diffusa, spiculis triforis, glumis trivialanccolatis, quinquenervibus basi villo con- lisnexis, stipula elongata.

P. Panicle/preading; fpikets 3-flowered, awoolly at the bafe: Htraul upright rough: Sheathfcale tapering to a point. Curt.

ROUGI?ISH MIADOW-GRASS. Moist mearlowa and fustures; very commoa.

P. June-...Sept.

P. panicula diffusa, spiculis quadrifloris, glu-pratenmis inceolat is quinquenervibus villo con. sis. nexis, stipula abbreviata obtusa.

P. Panicle fpreading; fpikets 5 -flowered, finooth: fircus cylindrical, upright. LiN . Sheath foule fhort and blunt. Curt.

smoOTH-STALKLD MEADOW-(iR ass. Meadows; pastures and banks; rery common

D.3 I. Wray, June. 


\section{TRIANDRIA. DIGYNIA. Briza.}

annua. P. panicula divaricata, fpiculis ovatis, flosculis remotiusculis quinquenervibus liberis, culmo obliquo compresso.

P. Panicle Spreading horizontally; branches in pairs: Jpikets moftly 4 flowered: leaves flat: Sheathes jmooth.

ANNUAL MEADOW-GRASS. Meadows, patures and gardens.

A. A pril-...Sept.

BRIZA. Smith. 108. With, 148.

Cal. bivalvis, multiflorus. Spicula disticha: Cor. bivalvis, ventricosa, valvulis cordat is obtusis. Semen corrollæ adnatum, depressum.

Cal. 2-valved, many-flowered. Spiket 2-rowed. Valves heart-jhaped, blunt: the inner minute.

media. B: spiculis ovatis septemfloris, calyce flosculis breviore, stipula brevissima obtusa.

B. Spikets egg-Jhaped: calyx fhorter than the florets.

COMMON QUAKING-GRASS. Meadows and pastures; frequent.

DACTYLIS. Smith. 110. With. 149.

Cal. bivalvis, compressus; altera valvula ma. jore, carinata.

Cal. 2-valved, many-flowred; values broader on one fide. Bloss. 2 values, inclosing the seed. Nectaries 2.

glome- D. panicula secunda supradecomposita glo. rata. merata. 
TRIANDRIA. DIGYNIA. Cynosurus. $3^{1}$

D. Panicle crowded, pointing one way.

ROUGII COCK'S-FOOT'-GRAss. Meadows; common.

P. June-..-August.

CYNOSURUS. Smith. 111. With. 150.

Cal. bivalvis, multiflorus. Recept. proprium unilaterale, foliaceum.

Cal. 2-valved, many-flowered, equal. Bloss. 2-valued, 1 value concave, longer. Nectary 2-leaved.

C. bracteis pinnato-distichis muticis, spica cristatus simplici lineari.

C. Floral leaves, with winged clefts.

CRESTED DOG'S-TAHL-GRASS. Pastnres; common.

P. June, July.

FESTUCA. Smith. 113. With. 151.

Cal. bivalvis. Spicula oblonga, teretiuscula, disticha; glumis acuminatis.

Cal; 2-valved. Spikets oblong, roundish. Husks tapering to a point, or terminating in on awn.

F. panicula secunda coarctata, flosculis tereti- ovina: usculis basi glabris, culmo tetragono, foliis setaceis scabris.

F. Panicle compact, awned: Araw 4-iornered, almost naked: leaves bristle-fhaped:

SHEEP'S FESCUE-GRASS. Dry barren pastures; not uncommon.

P. June.

F. panicula secunda diffusa, flosculis aristatis, durius. culmo tereti, foliis caulinis planis, radice cula. fibrosa. 
F. Panicle oblong: fpikets oblong, finooth: leaves bristle-Jhaped.

IARD FESCUR-'RASS. Dry places. P. June.

bromoi- F. panicula secunda erecta, flosculis subuladés. tis aristatis apice scabris, foliis setaceis vagina brevioribus.

1. Spikets upright; finooth: calyx valves; 1 cntere, the other taperning to an awn-like point.

BARREN FESCUE-GRASS. On walls and gandy phitices.

A. Sulde.

myurus. F. panicula securda mante elongata, flosculis subulatis aristalis anice scabris, folnis setaceo-subcarnatis beevissimis.

F. Punicle fpike-like, drooping: calyx fmaller valve very minute: fiorets rough, auns zery long.

WALL VESCEL-GiRASS. Walls and dry birren places.

A. Niay, Juse.

gigantea. F. panicula secunda mutante samosa lasa, flosculis lanceolat is ventricosis aristatis, 10. liis ensiformibus nerrosis.

F. Panicle drooping; Jpikets Af flowered, fhoiter than the awns.

Bromus giganteus. Whth. 152 .

TALL FESCUE-GRASS. In woods and moith hedges. Eperstone Wood. P. July, Aug.

loliacea. F. spica disticha nutante, spiculis subsessilibus lineari-oblongis, flosculis cylindricis enervibus muticis. 
F. Spiked: fpikets alternate, fitting, compresed, azonless.

SPIKEJ) FESCUE-(rRASS. Moist meadows; not very common. Southwell.

P. 3 une, July.

F. panicula secunda erectiuscula laxa, spicu-pratenlis linearibus compressis obtusiusculis, sis. flosculis cylindricis obsolete nervosis.

F. Panicle upright: Spikets fcarcely awned: the outer ones cylindrical.

Festuca elatior. With. 155. Var. 2.

MEADOW FESCUE-GRAS8. In mealows and moist pastures. $\quad$ P. June, July.

F. panicula subdiffusa nutante ramosissima elatior: laxa, spiculis ovato-lanceolat is acutis, flog: culis cylindricis obsolete nervosis.

F. Panicle upright: Jpikets farcely awned: the outer ones cylindrical.

TALL FESCUE-GRAS8. Boggy mendors, and sides of wet ditrhes.

P. June, July.

BROMUS. Smith. 125. With. 159.

Cal. bivalvis. Spicula oblonga, disticha. Arifta infra apicem. Gluma interior pectinato. ciliata.

Calyx 2-valved. Spikets obiong, cylindrical, 2.rowed. Aw beneath the point.

B: panicula patente; pedunculis subsinplici-secalibus, spiculis ovatis compressis decentloris, nus. flosculis distinctis teretiusculis.

B. Panicle expanding, hu/ks naked; Jeeds dis. tinct; awns fhorter than the blafforn, not quile Araight. 
GOOTH PYE PROME-GRASS. Meadows and pastures; not common. Sontlivell. A. July.

mollis. B. panicula erecta coarctata; pedunculis ramosis, spiculis ovatis, flosculis imbricatis depressis norvosis pubescentibus.

B. Panicle rather upright; leaves very foft and woolly: awn about the length of the blogrom.

SOFT PROME-GRASS. Cornfieids, pastures and hedre barks.

เ. June.

aper. B, panicula nutante ramosa, flosculis lanceolatis teretiusculis subenervibus, foliis uniformibus : inferioribus hirstitis.

B. Panicle drooping, rough; /itikets hairy, awned: leaves rough. LinN. Spikets flender, 10-flowered: Sheaths of the leaves hairy. Curt.

HAIRY WOOD BROME-GRASS. Noist woods and herlgea. Egerstone Wood. A. or B. July.

Rerilis. B. panicula nutante subsimplici, flosculis lanceolatis nervosis sulcatis, foliis pubescentibus.

B: Paricle fpreading; fpikets oblong : florets 2-rowed; calyx taper-pointed. Lin. Aivns very long.

BARREN BROBAE-GRASS. Wooda and hedges; frequetat. A. June, July.

Jylua- B. spica simplici nutante secunda, spiculis iicus. sessilibus teretiusculis, aristis gluma longiuribus, fuliis pilosis. 
B. Spikets futing; frraw undiviaed: awns as long as the bloffom.

Festuca sylvatica. Wrth. 158.

stevbER wOOD BROME-Gilass. Woods and hed.es. Kirklingion.

P. July.

AVENA. Smith. 139. Withering. 163.

Cal. bivalvis, multiflorus. Cor. valvula exterior dorso aristata ; arista contorta.

Calyx 2-valued; many-fiowered. Awn from the back of the biolfom, twifted.

A. paniculata, calicibus subtriforis, flosculis fatua. basi pilosis omnibusque arisedis enervibus.

A. Panicled: calyx 3 finwered, all the florets awned, and hatry at the bafe.

WILD OAT. HAVER. Comieh. Sonthreht

A Rugigust.

1. panicula erecta subsimplici, calycibus sub-pubescens trifloris, receptaculis barbatis, foliis planis pubecentibus.

4. Panicle fpilie like; calyx aflowered; biofforns bearded at the bife : leaves flat, downy.

Dow iures.

P. inne.

A. spica erecta, calycibus subquinquefloris, pratenreceptaculis pilosis involutis sermulatis nudis. sis.

A. Panicle fjike-like: calyx j-flowered.

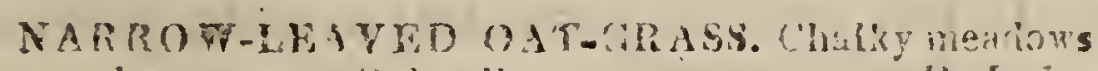
itnl pastures. Bulwell. P. Juiy.

A. panicula ramosissima laxa, crlycibus sub-flavescens trifloris inæequatbus, receptaculis pilosis, folits planis subpubescentibus. 
$3^{6}$ TRIANDRIA. DIGYNIA. Arundo:

A, Painicle loofe: calyx 3-flowered, fhort: all the florets awned.

YELLOW OAT-GRASS. Meadows and pastures.

P. June, July.

ARUNDO. Smith. 145. Withering. 166.

Cal. bivalvis. Flosculi lana persistente cincti.

Cal. 2-valved: Bloss. awnlefs, Jurrounded with down at the bafe.-

Fhrag-A. calycibus quinquefloris, panicula laxa. mites. A. Calyx 5-flowered: panicle Jpreading.

COMMON REED. Rivers, lakes and ditches. P. July.

Calama-A. calycibus unifloris corolla longioribus, pagrofiss. nicula erecta diffusa, floribus sparsis erectis foliis linearibus.

A. Panicle stiff and straight: blofoms fmail, hairy at the bafe; leaves flat. Calamagrostis Epigejos. With. 12.3.

SMALI, RLED. Moist woods and hedgeg. By the side of a bridle road, leading from Radley near Southwell, to Eperstone Woods. P. July.

LOLIUM. Smilh. 148. With. 167.

Cal. monophyllus, fixus, multiflorus. Flosculi distichi.

Cal. I leaf, fixed, many flowered. Spikets alternate.

perenne. L. spica mutica; spiculis calyce !ongioribus flosculis lanceolatis.

L. Spike awnless: fpiciets compressed, many. flowered, longer than the calyx. 


\section{TRIANDRIA. DIGYNIA, Hordeum.}

PERENNIAI, DARNEL. RED DARNEL, RAYGRASS. Meadows, pastures, and road sides; frequent. P. June.

L. spica aristata, spiculis calyce brevioribus, temuflosculis ellipticis, culmo superne scabro. lentum.

L. Spikets awned, compreffed, many-flowered; not longer than the calyx: ftraw rough.

BEARDED OARNEL. Ploughed lands. -Southwell.

A. July.

HORDEUM. Smith. 155. Withering. 170 .

Cal. lateralis, bivalvis, ternus, uniflorus.

Cal. lateral,2-valued, 1 -flowered; 3 together.

H. flosculis lateralibus masculis aristatis, glu- murinum. mis calycinis intermediis lanceolatis ciliatis.

H. Lateral florets male; awned, fmooth on the keel; involucrum of the intermediate florets fringed.

WALL BARIEY. MOUSE BARLEY. WAY BENNE'. Walls and road sides: common.

$$
\text { A. A pril-.-August. }
$$

H. flosculis lateralibus masculis brevius pratense. aristatis, glumis calycinis omnibus setaceis scabris.

H. Lateral florels male, awonlefs: involucrum briftle-Jhaped, rough.

MEADOW BARLEY. Moist meadow's and pastures. P. Juve.

TRITICUM. Smith. 158. With. 172.

Cal. bivalvis, solitarius, multiflorus, in rachi flexuosd, dentata.

Cal. 2-valued, folitary, mofly 3-flowered. Florets bluntish 


\section{TETRANDRIA. DIGYNIA. Montia.}

repens: T. calycibus subulatis, multinervibus, quinquefloris, flosculis acuminatis, foliis planis, radice repente.

T. Calyx 4-flowered, awl-jhaped, tapering to a point: leaves flat.

CREEPING WHEAT-GRASS. COUCH-GTASS.

Hedges; very common. P' ituie.

caninum. T. calycibus acuminatis subquinquenervibus quadrifloris, flosculis aristatis, toliis planis, radice fibrosa.

T. Calyx pointed, moftly 4:flowered: awns longer than the bloffom: Spkets upright.

FIBROUS, OR BEARDED WHEAT-GRASS. Woods and hedger, in a chalky soil. Southwell.

P. July.

\section{TRIGYNIA.}

MONTIA. Smith. 161. With. 175.

Cal, diphyllus. Cor. monopetala, irregularis. Caps. unilocularis, trivalvis, trisperma.

Calyx 2 leaves. Bloss. 1 peta!, zrregular. Caps. 1-celled, 2-valued.

fontana. MONTIA.

CHICK WHED. BLINKS. Springs and watery places. Coduington Moors; Oxiau Buttoms; Edingley Misors.

d. Aprit, sisy. 


\section{Classis $I V$. TETRANDRIA.}

Smith. 165. Withering. 178.

\section{Stamina 4.}

\section{MONOGYNIA.}

\section{Stylus 1.}

* Fl. monopetali, monospermi, superi.

1 Flowers of 1 petal and 1 feed: fuperior:

INCORPORATED.

DIPSACUS. Cal. communis polyphyllus, foliaceus; proprius superus. Pappus cyathiformis:

DIPSACUS. Cal, common, leafy. Receptacle conical ; chaffy. Seeds like little pillars.

SCABIOSA. Cal. communis polyphyllus; propri. us superus, duplex.

SCABIOSA. Cal. common, of many leaves. Recep. tacle convex, somewhat chaffy. Seeds crowned, rolled in a cover.

SANGUISORBA. Cal. uniflorus, inferus. Cor. su. nera.

\section{E 2}


SANGUISORBA. Bloss. flat. Cal. 2-leaves. Caps. 4-corned, between the cup and the bloffom.

* Fl. monopetali, dispermi, superi.

2 Flowers of 1 petal; superior; and 2 berries. STARRY.

GALIUM. Cor. plana. Fructus siccus:

GALIUM. Bloss. flat. Fruit nearly globular. Florets all hermaphrodite.

ASPERULA. Cor. tubulosa. Fructus muticus.

ASPERULA. Bloss. tubular. Fruit nearly globular. SHERARDIA. Cor. tubulosa. Fructus coronatus. Sem. tridentata.

SHERARDIA: Bloss. tubular. Fruit crowned. Sceds with 3 teeth.

* * Fl. monopetali, polyspermi, inferi.

3 Flowers of 1 petal; beneath the germen.

PLANTAGO. Cor: refracta. Caps. bilocularis, circumscissa.

PLANTAGO. Bloss. bent back as if broken. Cal. with 4 divisions. Caps. 2 cells; cut round. **** Fl. tetrapetali.

4 Flowers of 4 petals; above the germen.

CORNUS. Nectaria nulla. Drupa infera, bilocularis.

CORNUS. Cal. 4-toothed; deciduous. Drupa a nut with 2 cells.

***** Fl. apetali.

5 Flowers incomplete, beneath the germen. 
TETRANDRIA.

TETRAGYNIA.

PARIETARIA. Cal. quadrifidus. Semen calyce tectum.

PARIETARIA: Flowers hermaphrodile, and female. Cal. 4-cleft. Seed 1 ; elongated.

AlCHEMilla. Cai. octófidus. Semen nudum.

ALCHEMILLA. Cup. wilh 8 clefis. Seed 1 ; in clojed in the cup.

\section{TETRAGYNIA.}

\section{Styli 4 .}

ILEX. Cor. monopetala. Bacca tetrasperma.

ILEX. Bloss.' 1 pelal. Cal. 4-toothed. Berry with feèds.

SAGINA. Pet. 4. Caps. unilocularis.

SAGINA. Bloss. 4 pitals. Cal. 4 leaves. Caps. with 4 cells, and many jeed's.

RADIOLA. Pet. 4. Cal. multifidus, Caps, octolocu. laris, octovalvis.

RADIOLA. Bloss. 4 pelals. Cal. many-clefted: Caps. with 8 cells, and 8 valves.

POTAMOGETON. Pet. 4. Cal. nullus. Sem. 4. nuda.

POTAMOGETON. Bloss. none. Cal. 4 leaves. Sccds 4 : fliting. 
2 TETRANRIA. MONOGYNIA. Dipsacus.

\section{TETRANDRIA.}

\section{MONOGYNIA.}

DIPSACUS. Smith. 168. With. 18 .

Cal. communis polyphyllus: proprius superus, monophyllus. Receptaculum paleaceum. Pappus cyathiformis.

Cal. common many-leaved: proper fuperior. Receptacle chaffy.

fylueftris. D: foliis oppositis serratis, paleis rectis, involucris inflexis capitulo longioribus,

D. Leaves in oppofite pairs, united at the bafe: chaff fraight.

WII.D TEASEL. Hedges and ditch banks; frequent. South well; Newark.

pilo/us. D. foliis petiolatis appendiculatis, involucris deflexis capitulo aqualibus.

D. Leaves on leaf falks, with appendages at the bafe.

SHEPHERD,S ROD. SMALL TEASEL. In hedges; rare. Flintham Wood; Eperstone Wood; Hedge near Thurgarton, on the road to Nottingham. P. August.

SCABIOSA. Emith. 170. With. 183 .

Cal. communis polyphyllus: proprius duplex, superus. Recept. paleaceum, sive nudum.

Cal. common many-leaved: proper double, superzor. Recept. naked or chaffy. Seed wrapped in the proper cup. 
S. corollulis quadrifidis qualibus, foliis cau- fuccifa. linis dentatis, floribus subglobosis.

S. Blogoms 4-cleft, equal: Atem undivided: branches approachng : leaves fpear-eggShaped.

DFVIL'S-BIT SCABIOUS. Fields and pastures; frequent. Southwell; Edingley Moor. P. June---. Aug.

S. corollulis quadrifidis radiantibus, foliis pin-arvenfis. natifidis incisis, caule hispido.

S. Bloffoms 4-cleft. radiating: leaves wingcleft, jagged: Atem rough, with frong hairs.

FIFID SCABIOU's. Pastures and com fieldr. Heacon. field; Newark.

P. July, August.

S. corollulis quinquefidis radiantibus, foliis colum. radicalibus ovatis lyratisve crenatis: cauli-baria. nis pinuatifidis: laciniis linearibus.

S. Bloforns 5.cleft, radialing : root-leaves fimple, folloped: Jtem-leaves compound.

ShiAL, SCABIOUS. Dry hilly pastures, on a calcareous soil. Manstield.

June-..- September.

SHERARDIA. Smith. 171: Withering. $185 \cdot$

Cor. monopetala, infundibuliformis, supera. Semina duo, tridentata:

Bloss. 1 petal, funnel-jhaped, long. Seeds 2. nakea, crowned by the calyx.

S. foliis omnibus verticillatis, floribus termina-arvenfis. libus.

S. All the leaves in whirls: flowers torminating.

BLUE SIERARIIA, or IITTLE FIELD-MADDER. Corn and fallow ficld's ; cowmon. Coddington; Newark; Southwell; furnstield, A. May---Seqlt. 


\section{TETERANDRIA. MONOGYNIA A sperula.}

ASPERULA. Srith 178. Whthering, 185 .

Cor. monopetala, intundibuliformis, stipera.

Semina duo, giubosa

Bloss. 1 petal, funnel-jhaped. Seeds 2. globular, like cork.

adorata. A folitis octonis lanceolatis, florum fasciculis pedunculatis, frucou hispido.

A. Learles 8 in a whirl, Jpear-Shaped: flowers in bundles, on fruit-ftalks.

SWEUT WOOBRUFF, or WOOJROCE. Worts and filially piates. In the following woots; Combes, Fiperstote, Cixon, Flistian, Ossington, Rroxtow, Sakring Bral, Lourdes; and in the thickets near Oxtoin Toll-bar.

p. Aay.

GALIUM. Smth. 173. With. 186.

Cor. monopetala, plana, supera. Semina duo, subrotunda.

Bloss. 1 petal, bell. Ghaped, Ghort. Seeds 2, nearly olobilar, beneath; like cork.

* Fructu glabro.

1 Seeds fmooth.

cricia-G. folih quaternis ovatis hirsutis, caule supertum. ne simplici piloso, pedunculis lateralibus diphyllis.

Valantia cruciata. LinN.

G. Stem hairy, only branched at the base: leaves hairy, ggg-shaped, 4 in a whirl: fruit. fulks with 2 or 3 leaves.

CROSS-WOR r. MULi-WEED. Hedre banks; common.

1.. Miay.

palufire. G. folis quaternis obovat in in qualibus obtusis, caulibus difrusis superne ramosis. 
G. Leaves unequal, Atrap-spear Shaped, fmooth, entive, blunt 4, 5, or 6 in a whirl; ftems rough, fpreading, branched upwards.

WIITE WATER BED-STRAW. Moist meadows and commons. On Coddington and Langford Moors.

P. July.

G. foliis senis lanceolatis retrorsum serrato. uligiaculeatis mucronatis rigidis, corollis fructu nofum. majoribus.

G. Leaves in fixes, /pear. Jhaped, dagger-pointed, ftiff, bowed backivards: Jerratures prickly: blofjoms larger than the fruit:

ROUGH MARSII BFI-SLRAW. Meadows, pastures, and wet heaths. Parlis at Southwell: Coddington Moors. P. July, Aug.

G. foliis octonis linearibus sulcat is integerri-verum. mis scabris, floribus paniculatis congestis.

G. Leaves 8 in a whirl, frap-Shaped: flowering branches hort.

YELLOW BED STRAW. CHEESE RENNET. Sides of fields aud reads; frequent. Southwell; Newark.

P. July. August.

G. foliis octonis ellipticis obtusiusculis mu-Mollug cronat is margine scabris, fluribus paniculatis divaricatis.

G. Leaves 8 in a whirl, egg-flrap-Shaped, dagger pointed: somewhat serrated, greatly expanded: Atem feeble: branches greatly expanding.

GREAT HEDGE BED-STRAW. Hedges and heaths; frequest. Southwell,

P. June---August, 
46 TETRANDRIA, MONOGYNIA. Plantago:

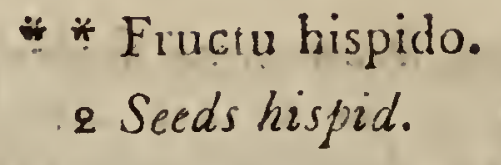

Aparine. G. foliis octonis lanceolatis carinatis scabris retrorsum aculeatis, caule flaccido, fructi. bus hispidis.

G. Leaves 8 in a whirl, Spear-haped: keel rough, with prackles pointing backwards: joints wolly.

GOOSE-GRASS, or CLEAVER'S. CATCAWRED. Hedges; freituent. Southwell; Newark.

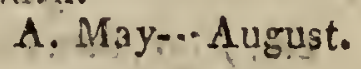

PLANTAGO. Smith. 183. Withering. 195.

Cal. quadrifidus.Cor. quadrifida, infera: limbo reflexo Stam. longissima. Caps. bilocularis, circumscissa.

Bloss, 4-cleft, permanent, the border broken back: Cal. 4-cleft. Stam. extremely long. Caps. 2.celled, cut round, superior.

major. P. foliis ovatis glabriusculis petiolo brevioribus, scapo tereti, spica floribus imbricata, seminibus plurimis.

P. Leaves egg-/haped; fmooth: Jtalk cylindrie cal: Spike tiled with florets:

GREATER PLANTAIN. Road sides; rery common. P. Sunc.--Augist.

media. P. folis ovatis pubescentibus petiolo lnngioribus, scapo tereti, spira cylindrica, seminibus solitaris.

P. Leaves egg-/pear-Jhaped, pubefcent: Spike and stalk cylindrical.

HOARY PLANTAIN. Road sidea and pastures; comanon.

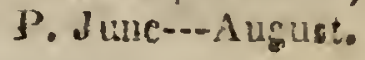


P. fóliis lanceolatis utrinque acutis, spica ova-lanceota nnda, scapo anguldo. lata.

P. Leaves fpear-shoped: spike nearly ego-shaped, naked: ftalk angulur.

RIBWORT PLANTAIN. Headons and patures; vefy common. P. Juk, July.

P. folitis linearibus pinnato dentatis, scapo Coronotereti.

P. Leaves frap-Jhaped, toothed: Falk cylindrical.

BUCKS-HORN PLANTAN STAR OF THE. EARTII. In sravelly so:l. Betscen Farnstield and Manfieht forest; upon the forest of sherwood, in man) places; in a lane leadiar from Mamselt fo siserwood llall.

A. Junte--Ang.

SANGUISORBA. Smith. 186. With. 199. Cal. quadrifidus. Germen inter caly cem corrollamque. Semen unicum.

Bloss. 4.cleft. Germen betwixt the calyx and the bloffom.

S. spicis ovatis.

S. Sprkes egg flaped.

pus.

GindT BURNAT. Mast pastures an merly or calcareous soils. Neadows at southwell, vevalk, aud Avertion. H. inne, Ju!y.

CORNUS. Smith. 187. With. 200.

Cal quadridentatus. Petala 4. Drupa infera, nuce biloculari.

Involucrum generally 4 -leaved. Petals 4 Juperoor. Drupa fucculent; berincatin: s.celled: hard; joltary. 
$4^{8}$ TETRANDRIA. MONOGYNIA. Parietal i.

fangui- C. ramis rectis, foliis ovatis utrinque viridinea. bus, cymis nudis planis.

C. Branches ftraight, leaves egg-Shaped, green on both fides: tuft flatted.

WIID CORNEL-TREF. DOG-WOOD. Woods and lestges. Hedges in the Quonce-Hill rlose, at Newark; Halaun Hill, southwell; Edingley Hill.

S. June.

PARIETARIA. Smith. 189. With. 2016

Cal. quadrifidus, inferus. Cor. nulla. Stamina elastica. Semen 1, calyce elongato tectum.

Flores aliquot fæminei calyce inmutato.

Fem. florets mixed wuth hermaphrodite on the same branch. Calyx 4-cteft. Bloss. none. Seed 1, superiour, lengihening.

offici. P. foliis lanceulato ovatis basi uninervibus, naiss. involucri laciuiis ovatis, caule erectiusculo.

P. Leaves Jpear-egg-Jlaped; fruit-ftalks forked: cup of a leaves.

PELLITORY OF THE WALl. On old walls, and anong rubbish. Rock-holes and crevices of the walls of Nottinghan Castle; Wails of Southwell Cathed:al and Thurgarton Church.

P. Junc---Sept.

ALCHEMILLA, Smith. 119. With 204.

Cal. octofidus, laciniis alternis minoribus, inferus. Cor. nulla. Semen. 1, nudum.

Calyx 8-cleft. Bloss. none. Seed 1 or 2 , inclofed by the calyx.

vulgaris. A. foli.. plicat s lobatis.

A. Leaves gafhed. 
TETRANDRIA. TETRAGYNIA. Ilex. 49

COMMON LADIES MANTLE. Woodland meadows and pastures. Southrell ; Thickets about Oxtou Tollbar; Eperstone and Oxton Woods. P.June,-..Sept.

\section{TETRAGYNIA.}

ILEX. Smith. 192. Withering. 210.

Cal. 4-vel 5-dentatus. Cor. rotata. Styli nulli. Bacca tetrasperma.

Flores aliquot masculi, quadrifidi.

Stam. and Pist. varioufly difpofed. Calyx 4toothed. Bloss, zuhcel-Shaped. Style none. Berry 4-Jeeded.

I. foliis ovatis acutis spinosis. Aquifo-

I. Leaves egg-fhaped, acute, thorny, on leaf lium. falks: flowers in a kind of umbel, axillary.

HOLLY-TREE. Woods and hedges. Soutbwell.

T. May.

POTAMOGETON. Smith. 193. Wilh. 211:

Cal. nullus. Petala 4. Stylus nullus. Semina 4.

Cal. none. Petals 4. Style none. Seeds 4.

$\mathrm{P}$ : foliis superioribus oblongo-ovatis petiolatis natens. natantibus.

P. Leaves oblong, egg. /haped, on leaf-Aalks; floating.

BROAD-1,EAYED POND-WEED. Ponds and slow river; cowinon.

P. July.

P. foliis cordatis amplexcaulibus omnibus perfoliimmersis.

atum.

P. Leaves heart-fhaped, Embracing the ftemo 
so TETRANDRIA. TETRAGYNIA. Sagina.

PERFOLIATE POND-WEED. Slow rivers and ponds; common. Kirklington Sill; Ossington. W. Jnly, Aus.

den/um. P. foliis ovatis acuminatis oppositis confertis, caule dichotomo, spica quádriflora.

P. Leaves egg-Shaped, tapering to a point: oppofite, crowded: ftem forked: Spike a-flowered.

CLOSE-LEAVED POND-YEED. Ditches and sIow streams.

P. June.

lucens. P. foliis ovato-lanceolatis planis in petiolos attenuatis, spica multiflora coarc̀tata.

P. Leaves very long and spear. Jhaped, fitting: upper ones oppofite.

SHINING POND-WEED. Rivers and ponds; frequent.

P. June, July.

crifpum. P. foliis lanceolatis alternis undulatis serratis.

P. Leaves Spear-fhaped, alternate, or oppofite, waved and ferrated.

CURLED POND-WEED. Ponds and low streanis; not uncommon. In the lower pond at Norwool Park.

P. Jume, July.

pectina. $\mathrm{P}$. foliis setaceis parallelis approximatis disŁum. tichis basi vaginantibus.

P. Leaves briftle-Jhaped, parallel, near together, pointing 2 ways.

FENNEL-LFAVED POND-WEED. Rivers and ponds. In the Race of the Water-mill, Southwell.

SAGINA. Smith. 199. With. 215. P. July.

Cal. tetraphyllus. Petala q. Caps. unilocularis. Calyx 4-leaved. Petals 4. Caps. 1-celled, 4walved, many-Jeeded. 
S. caulibus procumbentibus glabris, peta- procumlis brevissimis.

bens.

S. Branches tralling.

PROCUMBRT PEARL-WORT. Walls, roofs, sandy places, garden walks, paved courts; common. Edingley Moors; Coddington Hoors. P. May--Aug.

S: caulibus erectiusculis pubescentibus, peta- apetala. lis obsoletis.

S. Stem. rather upright, pubescent : flowers alternate, with very minute petals, notched at the end.

ANNUAL SMALL-FLOWERED PEARL-WORT. Walls, gravel walks, and other very dry places; not uncommon.

A. Mlay, June.

S. caule erecto subunifloro, foliolis calycinis erecta. acutis, petalis integris.

S. Stem upright, generally fupporting a fingle flower.

UPRIGITT PEARL-WORT. Gravelly soils. Edingley and Coldington Moors.

A. Niay.

RADIOLA. Smith. 201.

Cal. multifidus. Petala 4. Capfula supera, octovalvis, octolocularis. Semina solitaria:

Cal: many-clefted. Bloss. 4 petals. Caps. Juperior, with 8 values and 8 cells. Seeds folitary.

RADIOLA.

Linum Radiola. Linn. With. 323 .

millegrana:

ALL-SEED. Moist sandy heaths; rare. In the lane learling to Stupleford Moors, from the Sleaford Turnpike. A. July, August. 


\section{Classis $V$. PENTANDRIA.}

Smith. 203: Withering. 217.

Stamina 5 . MONOGYNIA.

Stylus 1.

* Fl. monopetali, inferi, tetraspermi. Asperrours. 1 Flowers of 1 petal; beneath; and 4 naked Jeeds. ROUGH-LEAVED.

ECHIUM. Cor. fauce nuda, irregularis. Stigma bipartitum.

ECHIUM. Bloss. mouth naked; irregular bellתhaped.

LITHOSERMUM: Cor: fauce nuda, infundibuliformis. Cal. quinquepartitus.

LITHOSPERMUM. Bioss. mouth naked; funnel Shaped: Cal. with 5 divisions.

SYMPHYTUM. Cor. fauce dentata, ventricosa.

SYMPHYTUM: Bloss. mouth toothed; bcllying. BORAGO. Cor. fauce dentata, rotata.

BORAGO. Bloss. mouth toothed; wheel Shaped. LYCOPSIS. Cor. fauce fornicta, infundibuliformis, tubo curvato, 
LYCOPSIS. Bloss. mouth closed; funnel-haped; tube crooked.

CYNOGLOSSUM. Cor. fauce fornicata, infundibuliformis. 'emina depressa, latere affixa.

CYNOGLOSSUM. Bloss, mouth clofed; funnelfhaped: Seeds depreffed; fixed fide-wways.

MYOSQTIS Cor. fauce fornicata, hypocrateriformis, lobis subemarginatis:

MYOSOTIS. Bloss. moutí clofed; salver-shaped; lobes notched at the end.

* Fl. monopetali, inferi, angiospermi.

2 Flowers of 1 petal; beneath. Seeds in a vessel. ANAGALLIS. Caps. unilocularis, circumscissa. Cor. rotatata. Stam. hirsuta.

ANAGALLIS. Caps. 1-celled; cut round: Bloss. wheel-jhaped. Suminit a knob.

LYSIMACHIA. Caps. unilocularis, decemvalvis. Cor. rotata.

LYSIMACHIA. Caps. 1-celled; 10-valued. Bloss. wheel-Shaped. Summit blunt:

PRIMULA. Caps. unilocularis, ore decemfido. Cor. fauce pervia, tubo cylindrico. Stigma globosum:

PRIMU1,A. Caps. t-celled. Bloss. funnel-ghaped; mouthopen. Summit a knob.

HOTTONIA. Caps. unilocularis. Cor. hypocraterifornis. Stam. fauce imposita, Stigma globosum. HOTTONIA. Caps. 1-celled. Bloss, two belozu the famen. Summit globular. 


\section{PENTANDRIA. MONOGYNIA.}

MENYANTHES. Caps. unilocularis. Cor. hirsuta, Stigma bifidum.

MENYANTHES. Caps. 1-celled. Bloss. shaggy. Summit cloven.

DATURA: Caps. bilocularis, quadrivalvis. Cor. infundibuliformis. Cal. deciduus.

DATURA. Caps. 2-celled; 4-valved. Bloss. funnelThaped Cal. deciduous.

HYOSCYAMUS: Caps. bilocularis, operculata. Cor. infundibuliformis. Stigma capitatum.

HYOSCYAMUS. Caps. 2-celled; covered with a lid. Bloss. funnel-Shaped. Summit a knob.

VERBASCUM, Caps, bilocularis. Cor. rotata. Stig: ma simplex. Stam. declinata, barbata.

VERBASCUM. Caps. 2-celled. Bloss. wheel-fha : ped. Stamens declining. Summit blunt.

CHIRONIA. Caps. bilocularis. Cor. hypocrateriformis. Anthera demum spirales.

CHIRONIA. Caps. 2-celled. Bloss. funnel-Shaped. Anthers spirally twifted after flowering.

CONVOLVULUS. Caps. bi-vel tri-locularis. Sem: bina. Cor. companulata, plicata. Sitgmata duo.

CONVOLVULUS. Caps. 2 -celled; 2 seeds. Bloss. bell-Shaped. Summit cloven.

VINCA. Folliculi duo, crecti. Cor. hypocrateriformis.

VINCA. Seed vessel a upright little bags. Bloss. falver-fhaped. Seeds fimple.

SOLANUM. Bacca bilocularis, Cor, rotata. Anths$r \boldsymbol{\alpha}$ biporosæ. 
SOLANUM. Berry 2.celled. Anthers with a holes in each.

ATROPA. Bacca bilocularis. Cor. campanulata. Stam. distantia, incurvata.

ATROPA. Berry 2-ceiled. Stamens distant; crooked. * * Fl. monopetali, superi.

3 Flowers of 1 petal; fuperior. Seeds in a vessel. SAMOLUS: Caps. unilocularis, apice quinque. valvis. Cor. hypocrateriformis.

SAMOLUS. Caps. 1-celled; 5.valved at the top: Bloss. Jalver - Maped. Summit a knob.

JASIONE, Caps. semibilocularis, apice dehiscens. Cor. rotata, quinquepartita. Stigma clavatum.

JASIONE. Caps. 2.celled Bloss. regular. Anthers adhering together. Cal. common, 10.leaved.

CAMPANULA. Caps. tri-sive quinquelocularis, perforata. Cor campanulata. Stegma trifidum.

CAMPANULA. Caps. 3 or 5-celled; perforated. Bloss. bell-fhaped. Summit 3 .cleft.

LONICERA. Bacca bilocularis, polysperma. Cor. irregularis.

LONICERA. Berry a celled; roundifh. Bloss. irregular. Summit a knob.

**** Fl pentapetali, inferi

4 Flowers of 5 petals; beneath the germen.

RHAMNUS. Bacca trilocularis. Cal. urceolatus corollifer.

RHAMNUS. Berry 3-celled; roundish. Calyx tubular. refembling a blodJum, wath 5 converging Jcales at the mouth. 


\section{6 - PENTANDRIA. MONOGYNIA.}

EUONUMUS. Caps. quinquelocularis. Sem. calyptrata. i al. planus.

EUONYMUS. Berry like a rap/ule; lobed. Cal. expanding. Seeds in a berry-leke feed-coat.

VIOLA. Caps. unilocularis, trivalvis. Cal. pentaphyllus, calcaratus. Cor. irregularis.

VIOLA. Caps. 1-celled; 3 valved. Bloss. irregular, with a fpur behind. Anthers adhering together. Cal. 5 leaves.

**** Fl. pentepetali, superi.

5 Flowers of 5 petals; above the germen.

RIBES. Bacca polysperma. (al. corollifer. Siylus bifidus.

RIBES. Berry many feeded. Cal. bearing the blos. som. Style cloven.

HEDERA. Bacca pentasperma, calyce cincta. Stylus simplex.

HEDERA. Berry a feeded; clapped by the calyx. Summit fimple.

\section{DIGYNIA.}

\section{Styli. 2.}

* Fl. monopetali, inferi.

1 Flowers of 1 petal; beneath the germen.

GENTIANA. Caps. unilocularis. Cor basi tubulosa, puris nectariferis destituta. 
GENTIANA. Caps. 1-celled; 2-valved. Bloss. tubular. Receptacles of the feeds, 2.

CUSCUTA. Caps, bilocularis. Cor: campanulata. CUSCUTA. Bloss. 4-cleft; egg-Jhaped. Cal. 4cleft. Cap. 2-celled; cut round.

* * Fl. incompleti.

2 Flowers incomplete.

CHENOPODIUM. Sem. unicum, lenticulare, su. perum.

CHENOPODIUM. Seed round and flat. Cal. with 5 divifions; Jegments concave.

HERNIARIA: Caps. monosperma, corticata. Frlam. quinque sterilia.

HERNIARIA. Seed 1; egg-Jhaped; covered. Cal. with 5 divifions. Filaments 5 Jterile ones.

ULMUS. Caps. monosperma, membranacea. compressa.

ULMUS Berry juiceless; compreffed. Cal. I leaf: Jhrivelling.

* * Fl. pentapetali, superi, dispermi. UMBELLATE. 3 Flowers of 5 petals, moftly of 2 Jeeds.

UMBELLIFEROUS.

A. Involucro universali partialique. A. Involucrum general, and partial. HYDROCOTYLE. Umbella simplex. Sem. com. pressa.

HYDROCOTYLE. Flowers in a fort of umbel: fertile. Seeds comprefjed.

SANICULA. Umb. subcapitata, disco abortiente. Sem. uncinato-muricata. 


\section{$5^{8}$ PENTANDRIA. MONOGYNIA.}

SANICULA. Flowers in a fort of umbel; centrat ones barren. Seeds prickly.

HERACLEUM. Fl. radiati, abortivi. Invol. deciduum. Sem. membranacea:

HERACLEUM. Flowers radiate; fome barren. Invol. decrduous. Seeds membranaceous.

CENANTHE. Fl. radiati; disci steriles. Sem.coronata, sessilia.

ENANTHE. Flowers radiate; outer ones barren. Invol. fimple. Seeds crozuned, fiting.

CAUCALIS. $F l$. radiati; abortivi. Invol. simplex. Sem. muricata.

CAUCALIS. Flowers radiate; central ones barren. Invol. fimple. Seeds prickly.

DAUCUS. $F l$. radiati, abortivi. Invol. pinnatum. Sem. muricata:

DAUCUS, Flowers radiate; central ones barren. Invol. winged. Sceds rough with hairs.

PEUCEDANUM. Fl. flosculosi, abortivi. Invol. simplex: Sem. compressa, alata, striata.

PEUCEDANUM. Flowers uniform; central ones barren. Invol fimple. Sceds deprefjed; fcored.

CONIUM. Fl. flosc. fertiles. Pet. cordata. Sem. gibba, costato-sulcata. Invlucella dimidiata.

CONIUM. Flowers uniform; all fertile. Partial Invol. extending but half way round. Petals heartShaped. Seeds bulging; ribbed ana' furrowed.

BUNIUM. Fl. flosc. fert. Pet. cordata. Involucella setacea.

BUNIUM. Flowers uniform; all fertile. Partial Invol. like briftles. Petals heart-jhaped. 
SIUM. Fl. flosc. fert. Pet. cordata. Sem. subovata: striata.

SIUM. Flowers uniform; all fertile. Petals heartfhaped. Seeds nearly egg-fraped; fcored.

ANGELICA. Fl. flosc. fert. Pet. incurva. Umbeblula globosæ. iem. hemisphærica, trialata.

ANGELICA. Flowers uniform; all fertile. Umbellules globular. Petals nearly flat.

SISON. Fl. flosc. fert. Pet. inflexa. Umbella depauperata. Sem. ovata, striata.

SISON. Flowers uniform; all fertile. Umbel of few Spokes. Petals nearly flat.

B. Involucris partialibus, universali nullo.

Involucrum oniy partial.

ETHUSA. Fl. subratiantes, fertiles. Involucella dimidiata.

CETHUSA. Flowers fomewhat radiate: all fertile:

Partial Invol. extending but half way round.

CH.ÆOPHYLLUM. Fl. subradiantes, abortivi.

Involuc. reflexa, concava, pentaphylla.

CHÆROPHYLLUM. Flowers uniform; central ones barren. Partial Invol. of 5 leaves.

SCANDIX. Fl. radiati: abortivi. Fruct. subulatus: SCANDIX. Flowers radiate; central ones barren. Fruit oblong.

PHELLANDRIUM. Fl. flosculosi, feriles. Fruct. coronatus.

PHELLANDRIUM. Flowers uniform; all feriile. Fruit croiuned.

CICUTA. Fl. Hosc. fert, Fruct. subovatus. 
CICUTA. Flowers uniform; all fertile. Petals flattifh.

C. Involucro nullo; vix universali, nunquam partialibus.

C. Involucrum none; neither general nor partial.

APIUM. Involucrum morophyllum. Fl. flosc. fert. Fruct. costatus. Pet. inflexa.

APIUM. Flowers uniform; almoft all fertile. Petals bent inwards. Seeds minute; fcored.

PIMPINELLA. Fl. flosc. fert. Fruct. striatus. Stigmata subglobosa.

PINiPINELLA. Flowers uniform; all fertile. Um. bels before flowering, nodding. Petals heart-Jhaped. ALGOPODIUM. Fl. flosc. fert. Fruct, ovatus, striatus. Stigm. simplicia.

EGOPODIUM. Flowers uniform; all ferite. Seeds bulging; fcored. Petals heart-Jhaped.

ANETHUM. Fl. flosc, fert. Fruct. subcompressus, utrinque tricostatus.

ANETHUM. Flowers uniform; all fertile. Seeds bordered; fcored.

PASTINACA. Fl. flosi. fert. Fruct. compressoplanus.

PASTINACA. Flowers uniform; all fertile. Seeds depreffed and flat.

SMYRNIUM. Fl. flusc. abortivi. Semina reniforma, angulata.

SMYRNIUM. Flowers uniform: central onesbar. ren. Seeds kidney. Shaped; angulur. 


\section{PENTANDRIA. TRIGYNIA. 61}

CARUM. Fl. flosc. abort. Sem. gibba, striata. CARUM. Flowers uniform: central ones barrens Seeds bulging; fcored.

\section{TRIGYNIA.}

\section{Styli 3 .}

* Elores superi.

1. Flowers above the germen.

VIBURNUM. Cor. quinquefida. Bacca monosperma.

VIBURNUM: Bloss. 5-cleft. Berry 1-feeded. SAMBUCUS. Cor. quinquefida. Bacca trisperma. SAMBUCUS. Bloss. 5-cleft. Berry a-feeded.

\section{TETRAGYNIA.}

Styli 4 .

PARNASSIA, Nectaria ciliata setis globiferis. PARNASSIA. Bloss. 5 pelals. Nectaries 5: fringed with glands. Caps. 4 -valved. 
62 PENTANDRIA. PENTAGYNIA.

\section{PENTAGYNIA.}

Styli 5 .

IINUM. Cor. pentapetala. Caps. decemlocularis. LINUM. Bloss. 5:petals. Caps. 10.celled: 1' Jeed in each cell.

\section{HEXAGYNIA.}

\section{Styli 6.}

DROSERA. Cor pentapetala. Caps, trivalvis, polysperma.

DROSERA. Bloss. 5-petals. Caps. 1.celled; open. ing at the top:

\section{POLYGYNIA.}

Styli plurimi.

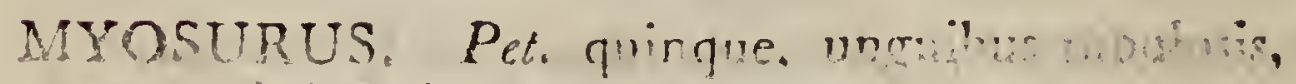
rucitariferis. Som. mita 
PENTANDRIA. MONOGYNIA. Myosotis. $b_{3}$

\section{PENTANDRIA. \\ i MONOGYNIA.}

MYOSOTIS. Smith. 212. With. 225.

Cor. hypocrateriformis, quinquefida, subcmarginata: fauce clausa fornicibus.

Blossom falver-finaped, 5-cleft, lobes notched. Mouth clofed with projecting fcales. Nuts 4, imperforated.

M. seminibus nudis, foliis elliptico lanceola-fcorpitis, racemis ebracteatis multifloris. oides:

M. Seeds fmooth: calyxes egg-Ghaped, tapering to a point; very hairy, longer than the tube of the bloffom: leaves egg-Spearjhaped.

M. arvensis. With.

MOUSE-FAR SCORPION-GR ASS. In sandy places; common.

A. May, June.

B. M. Seeds fmooth: calyxes inverfely eggShaped, blunt, Jmooth, as long as the tube of the bloffom: leaves Jpear. Shaped.

M. palustris. With.

WATER MOUIE-FAR. SCORPION-GRASS. Wet ditches, springs, rivuleis. $\quad$ P. May---July.

LITHOSPERMUM. Smith.213. With. 226 :

Cor. infundibuliformis: fauce pervia, nuda, Cal. quinquepartitus.

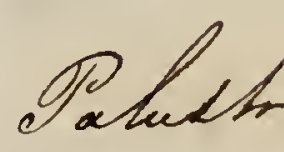

c 2 
$6_{4}$ PENTANDRIA. MONOGYNIA. Cynoglossum.

Blossom funnel-ghaped, tube long. Render, open and without valves at the mouth. Cal. with 5 divifions.' Nuts 4 , very hard, imperforated.

offici- L. seminibus lævibus, corollis calycem vix nale. superantibus, foliis lanceolatis acutiusculis venosis.

L. Seed's smooth; bloffoms hardly longer than the cup: leaves fpear-Jhaped.

COMMON GROMWELL. GRAY MILL. GREY MILLET. In dry gravelly soils. Thorny-moor Holt, near southell. in a close near llalam beck. In a ledwe between Broxtow and Wigley Woods. P. May.

aruenfe. L. seminibus rugosis, corollis vix calycem superantibus, foliis obtusis aveniis.

L. Seeds wrinkled: bloffoms hardly longer than the cups.

CORN GRONWELL. BASTARD ALKNVET. Cornfields. In cornficlds between Kirklington turnjike-roarl, and Rclla Park; Keacon-ficlds, near Newark; lielus between Ncwark and Ifawton.

A. May, June.

CiNOGLOSSUM. Smith.216. With. 227.

Cor. infundibuliformis; fauce clausa fornicibus. Sem depressa, interiore tantum latere stylo affixa.

Bloffom funnel-Shaped: mouth clofed by projecting values. Nuts 4 depreffed, fixed to the fyle by the inner fide only, imperforated.

offici- C. staminibus corolla brevioribus, foliis latonale. lanceolatis tomentosis sessilibus.

C. Stamens frorter than the blnffom: leaves. broad, Spear-fhaped, fiting, cottony. 


\section{PENTANDRIA. MONOGYNIA. Symphytum. $6_{5}$}

COMMON HOUND'S-TOVGUE. Rozd sides, and amnnast mbbich; not frequent. In herlge bottoms, and lines about Collingham; Mansfield.

B. June.

SYMPHYTUM. Smith. 218. With. 230.

Cor. limbus tubulato-veritricosus, fauce clau. sa radiis subulatis. Cal. quinquepartitus:

Bloss. funnel-fhaped, bellying towards the top: mouth clofed by hollow radiate values, which have an cpen hole on the outfide, near the border. Nuts 4, perforated.

S. foliis ovato-lanceolatis docurrentibus.

officinale.

S. Leaves egg-Jhaped, decurrent.

COMMON COMFREY. Banks of rivers-and wet ditches. In a ditch in a close at Ossington.

P. May, June.

BORAGO.

Cor. rotata, fauce radiis clausa.

Bloss. wheel-fhaped: mouth clofed with rays. Nits 4, not perforated.

B. foliis omnibus alternis, calycibus patenti- officibus. nalis.

B. All the leaves alterate: calyxes expanding: COWMON BORAGE. Walls, and amongst rubbish. Newark; but certainly not indigenious. B. June, July.

LYCOPSiS. Smith. 220. Wuh. 231. Cor. tubo incurvato, fauce ciausa squamis convexis.

Bloss. tube crooked: mouth clofed with fcales. Nuts 4, perforated. 
66 PENTANDRIA. MONOGYNIA. Echium.

arvenfis. L. foliis lanceolatis hispidis, calycibus florescentibus erectis.

L. Leaves /pear. Shaped, rough with hair: calyx while in flower upright.

SMALL BUGioss. Cornfields and road sides. Sonthwell; Mansfield; Newark.

A. June, July.

ECHIUM: Smith.221. With. 232.

Cor. irregularis, fauce nuda. Stigma bipartitum.

Bloss. irregular; mouth naked. Nuts 4 , large, rough, imperforated.

vulgare. E. caule tuberculato hispido, foliis caulinis lanceolatis hispidis, spicis lateralibus pilosis deflexis.

E. Stem rough with briflles and tubercles: flemleaves Spear-Jhaped, rough with hair: flowers in lateral Spikes.

COMMON BLUE VIPER'S BUGLOSS. In s.n.ly ground, and among rubbish; frequent. Farusfielli; Blidworth; Mansfield.

B. July:

PRIMULA. Smith. 222. With. 233 .

Caps. unilocularis, ore decemfido. Corolla tubus cylinàricus, fauce pervia. Stigma globosum.

Bloss. tube cylindrical; mouth open. Stem within the tube. Caps. 1-celled, cylindrical, many-Jeeded, opening with 10 teeth. Summit a knob.

vulga- P. foliis dentatis rugosis, scapis unifloris, co1is. rollæ limbo plano. 
PENTANDRIA. MONOGYNIA. Menyanthes. 67

P. Leaves wrinkled, toothed; border of the bloffom flat.

COMMON VRI HROSF. Woods, heigesagd thicigets, paricularly in a clajey soil. $I^{2}$ April.

P. foliis dentatis rugosis medio contractis, elalior. scapo multifloro, corollæ limbo plano.

P. Leaves wrinkled and toothed: Rath many. flowered; outermoft flowers drooping: border of the bloffon flat.

OXuP. GPYAr COWSIIP. Woods and shady places; not common. Thictets ne?r ()xton Toll-bar, with P, vulgaris: liperstone Wood.

P. foliis dentatis rugosis medio contractis, veris. scapo multifloro, corollæ limbo concavo.

P. Leaves wrinkled and toothed: flalk manyflowered; all the flowers drooping: border of the bloffom concave.

P. officinalis. Wtth.

COMMON COWSIP, or PAIGLE. Pastures; common. Southwell; Newark. - April.

CYCLAMEN. Smith. 224. With. 235.

Cor. rotata, reflexa; tubo brevissino; fauce prominente. Bacca tecta capsula.

Bloss. wheel- - hhaped, reflected; tube very Short; mouth projecting. Recept. flefhy, Jupporting a berry inclofed in a caje.

C. corolia retrosflexa, foliis cordatis angulatis denticulatis.

C. Blofom bent back as if broken; leaves cir. cular, folloped.

SPRING CYCLAMEN, or SOW BRIAD. In woors and thickets, probibly not indigenous. In the roods at Langar, the seat of Lur! Howe.

P. April.

europaum. 
MENYANTHES. Fmith. 225. With. 235.

Cor. hirsuta. Sigma bifidum. Capsula unilocularis.

Bloss. hairy, or fringed. Nect. 5 at the bafe of the germen. Summit 2-lobed. Caps. 1-celled.

trifoli-M. foliis ternatis, corolla superne villosissiata. ma.

M. Leaves growing by threes: blufom fegments entire at the edge, haggy on the upper furface.

BUCKBEAV. MARSH TREFOIL. In marshy grounds. Bdingley Monr: Oxton Rotroma: pientifully. Basford scottum; in a Pond near Oxton Toll-bar.

P. June, July.

HOTTONIA. Smith. 226. With. 236 .

Cor. hypocrateriformis Stam. fance inserta, lobis opposita. Caps. unilocularis. Stigma glubosum. Cal. quinquepartitus.

Bloss. salver-Mhaped. Stam. fixed to the top of the tube. Summit globular. Caps. 1-celled, globular.

palufris. H. caule multifioro, pedunculis verticillatis. H. Fruit-flalks in whirls, many.flowered.

FEATHERFOLL. WATER VIOLET. Ponds and ditohes. In the Ditches beynd the Bridge on the Roadfrom Newark to Kelham; about Fidler's Hridere, in the Foot-way to Kelham. P. June, July.

LYSIMACHIA. Smith. 227. With. 237 .

Cor. rotata. Caps. globosa, mucronato, deccmvalvis.

Bloss. wheel-ghaped. Caps. globular, daggerpointed; of 1 cell, 5 values, and many jeeds. 
* Pedunculis multifloris.

1 Fruit-falks, many-flowered.

L. paniculata, recemis terminalibus, foliis vulgaris. ovato-lanceolatis acuris.

L. Panicled: bunches terminating.

YBLLOW LOOSFSTR!FE. Banks of rivers, and shady inarshes; not common. In a Villow-holt by the River between romwell and Collinghum on the River-bank Luder Flintham. Hood near Hazelford Ierry.

P. July.

* Pedunculis unifloris.

2 Fruit-Ralks, 1-flowered.

L. foliis ovatis acutis, floribus solitariis, nemorumb caule procumbente, staminibus levibus.

L. Leaves egg-Jhaped, acute; flowers folitary: feem trailing.

WOOD LOOSESTRIFE. YELLOW PIMPERNEL. Woods and shady places. In the following Woods: Eperstone, Comber, Flintham, Ossington, Broxtow; Brockwood Hills. $\quad$ P. May-.-Sept.

L. foliis subcordatis, floribus solitariis, caule Nummurepente, staminibus glandulosis.

laria.

L: Leaves fomewhat heart-fhaped: flowers folitary: ftem creeping.

CREEPING LOOSESTRIFE. MONEY-WORT, or HER B TWOPEN CL. Moist meadows and wet shady places; not uncommon. In the Old Trent Ditches beyond Newark Bridge, on the Kelham Road; Southwell Water-mill; Banks of the River Greet.

P. June, July.

ANAGALLIS. Smith. 229. With. $23^{8 .}$

Cor. rotati. Caps. circumscissa. Stam. hirsuta. 
Bloss, wheel haped. Caps. cut round: of 1 cell, and many-feeds.

arvenfis. A. foliis ovatis subtus punctatis, caule procumbente.

A. Leaves egg. Spear-ghaped: Atem trailing: calyx Jegments Spear-jhaped.

SCARLET PIMPERNEI. Corn-fields and samly places; conmon. Southwel; Mansfield; Newark, Beacun rields.

A. June, July.

tenella. A. foliis subrotundis acutiusculis petiolatis, caule repente, stigmate acuto.

A. Leavies egg-Shaped, rather acute: ftem creeping, ftriking root at the joints.

BOG PIMPERNEL. Wet heaths and turfy bogs. Oxton Bottoms; Boggry ground in the Quonce Close, Newark; Basford Scottum; Gamston Moors near Nottingham; Coddington Carr Grounds; Close at Halam Beck near Southwell; ddingley Hocr.

$$
\text { P. July, August. }
$$

CONVOLVULUS. Smith. 232. With. 239 .

Cor. campanulata, plicata. Stigmata duo. Caps. bi-vel tri-locularis; loculis dispermis.

Bloss. bell-ghaped, plaited. Nect. furrounding the baje of the germen. Summits 2: Caps. 2 or 3-celled, 2 Jeeds in each.

arvenfis. C. foliis sagittatis utrinque acutis, pedunculis subuniforis, bracteis minutis a flore remotis.

C. Leaves arrow- Shaped, acule on each fide: fiuit-flalks bearing generally a flower.

SMALI, BINDWEED. Corn-fields, road sides, and in Gardens; comunon. P. June, July. sepium. C. foliis sagittatis postice truncatis, peduncu. 
lis tetragonis unifioris, bracteis cordatis calyci approximatis.

C. Leawes arroun Raped. lopped at the bafe: fruit-ftalk \& corned, bearng i flower.

GREAT BINDSEED. In hedses. In the Bushes on the Buak of he Old I rent Ditches near Newark Bridge.

P. July, August.

CAMPANULA. Smilh. 234. With. 241.

Cor. campanulata, fundo clauso valvis staminiteris. Etigna trifidum. Caps. infera, poris tateralibus dehiscens.

Bloss. bell. fhaped. Filaments broad and arched at the bafe. Summit 3 clefi. Caps. beneath: 3 -celled; opening at 3 lateral holes.

C. foliis radicalibus reniformibus; caulinis rolun. linearibus.

difolia.

C. Root-leares kidney-Jhaped: Rem.leaves, Strap-haped, very entire.

ROUND-LLAVID BRLL-IILOUER. Feaths, road sites, and bedere hanks: commcr. Newark; Southwell; S.ternad Forest. P. August, Sept.

C. foliis undulats: radicalibus lanceolato- Rapunovalibus, panicula codrctata.

culus.

C. Leaves waved: rool leaves /pear oval: panicle compact.

RAMPIOR BHLL-FLOARR. Heslge banks, fallowfieldp; rare. in a Flantation at coldingtorit.

Hr. if ich3 URUOY No.

DEERIAG p. 185 mentions this flant as growing in "adford Hollowe, near Nol tinghum; it is pot, hoatever,

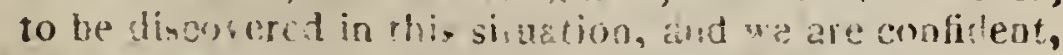

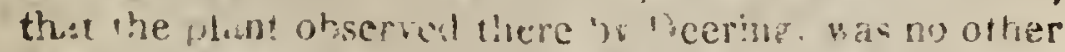

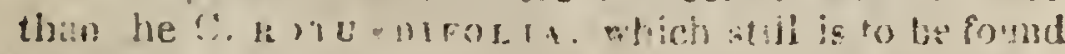
abundiatly in the saner syot. What coufirms this o- 


\section{PENTANDRIA. MONOGYNIA. Campanula.}

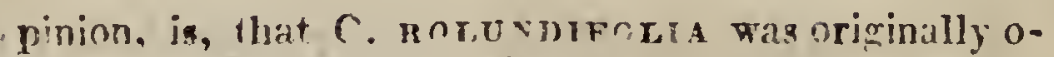
mited by Decring, and afterwar.ls inserted among the a:'de:ma.

latifo. C. foliis ovato lanceolatis, caule simplicissilia. mo tereti, pendunculis unifloris, tructibus cernuis.

C. Leaves egg-/pcar-Jhaped: fem unbranched, cylindrual. flowers joluary, on fruit-jtalks: frutt drooping.

GIANT BEII-FLOWFR. In woods and thickets. In the following roods: I.ounds near Fakring, Broxtow, Colwick, Osington, Wemham, Fliutham, W inkburn and Kirlington, Westhorpe Dumal, near Southwell.

P. August.

Trache-C. caule angulat:, foliis cordato-lanceolatis lium. acute serratis, calycibusque hispidis, peduncults axillaribus paucifloris.

C. Stem angular; leaves on leaf-fialls; cups franged; juit talks 3 -sleft.

NETTIE-LE \& VF!) BELI-FIOWER. In Colwick Wool; between Ralford feld and the Cherry-holt, neal Asply. Drining.

As the C. LA Trosia yrows in the places mentioned by Deering, and the C. Traculum has not yel presented itself to us in Not!inghanshire, we suppose that our "r. dicessor was mistalien.

glome-C. caule angulato simplici, floribus sessilirata. bus, capitulo terminali, foliis ovatis crenatis.

C. Stem angular, not branched: flowers fitting in a terminating head.

CLUSTERED BHLL-FLmWER. Meadows and pastures. In the Meadow of Newark, plentifully; where 1 have found a variety with milk-wlite flovers. Averham Mleadow. In everal places about Mansfield. DEEAI G.

T. July. 


\section{PENTANDRIA. MONOGYAIA. Iasione. 73}

\section{IASIONE. Smith. 241. With. 247 .}

Cor. rotata, quinqucpartita; laciniis linearibus. Stigma clavatum bifidum. Antherce basi connexz. Caps. infera, semibilocularis, apice dehiscens.

Common calyx 10-leaved. Cup proper 5toothed. Bloss. 5 petals, regular. Anthers united. Caps. beneath; a.celied; many-jeeded, opening at the top, crowned by the proper cilp.

\section{IASIONE.}

I. Leaves frap fhaped, very entire:

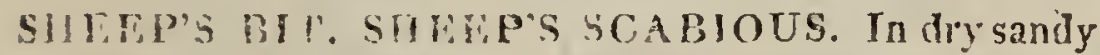
placs. Sirybata by the side of the roal from Newal? io ? incoln, oppuste Mr. Dunoomb's IJouse, at landiord; nore abundautly on the Banls by the Poarl unleg hr. Pocklinglon's Plintations, at Muskham: Famafelt.

A. Jure, July.

VIOLA. Smith. 244. Withering. 260.

Cor pentapetala, irregularis, postice cornuta. Anther subcohærentes. Caps. supera, trivalvis, uniocularis. Cal. pentaphyllus, basi productus.

Calyx 5-leaved, adhering to the bloffom above the baje. Bloss. 5 petalls, irregular, with a four behind. Antiners cohering. Caps. 1celled, 3 vulued.

$V$. acanlis, foltis cordatis petiolisque piloso- hivta. hispidis, calycibus obutusis.

V. Lecules hewi-flaped, rough with frong hair; Teat.faths rowgh zunth hair; floral deaves beivie the middle of the fruit flath. 


\section{FENTANDRIA. MONOGYNIA. Viola.}

HAIRY VIOLET. Shady places, and hedge banks. Lanes edjoining the Moors of Coddington and Langford; Barnby in the Willows; Westhorpe Dumble. P. April.

-dorata. V. acaulis, stolonibus reptantibus, foliis cordatis petiolisque glabriusculis, calycibus obtusis.

V. Leaves heart-Jhaped; Juckers creeping; floral leaves above the middle of the fruitfa!k.

SWEET VIOLET. Warm hedges, banks and moist warm lanes; particularly in clay or marle; common. Southwell ; Newark; Nottingham. P. Narch, A pril.

palus- V. acaulis, foliis reniformibus glabris, radice tris. repente.

V. Leaves kidney-Jhaped.

MARSH VIOLET. Moist meadows; peaty and mossy bogss ; rare. On Farnsfield Carr; Oxton bottoms; mossy banks on Stapleford Moors, near the spot where Osmunda regalis grows. $\quad$ P. A pril.

canina. V. caule adultiore adscendente canaliculato, foliis oblongo-cordatis, calycibus acutis.

V. Stem ascending as it attains its full growth: leaves oblong-heart-Jhaped.

DOG'S VIOI.ET. Shady places, heaths, helge banks, common. On Stapleford, Coddington, and Laingford Moors; plentifully. Halain and P.dingley Hills; Southwell.

P. April...June.

tricolor. $\mathrm{V}$. caule angulato diffuso, foliis oblongis dentato-crenatis, stipulis ly rato-pinnatifidis.

V. Stem branched; leaves egg-fhaped, toothed: calyx Jmooth, but half the fize of the bloffom.

PANSY VIOLET. HEART'S-RASE. Cornfields; sides of paths, gardens, and cultivated ground. Among corn, and in fields about Newark, Southwell, Mansfield, aud Nottingham. A. May--Sept. 
PENTANDRIA. MONOGYNIA. Verbascum. 75

VERBASCUM. Smith. 249: With. 248 .

Cor. rotata, irregularis. Stam. declinata, barbata. Caps. superd, bilocularis, valvulis inflexis, polysperma. Stigma simplex.

Bloss. wheel-ghaped, nearly regular. Caps. 2-celled; 2-valved; many-jeeded.

$\mathrm{V}$. foliis decurrentibus utrinque tomentosis, Thapcaule simplici.

V. Leaves decurrent, coltony onboth fides: fem unbranched: Juminit globular.

GREAT MULERIV. HTRH TAPER. Dry ditch banks, iu chalky or gravelly soils. On bauks going into Collinghan, from Newark; Mansfield Stone Quarries; Linby; Bulwe!l. B. July, Aug.

V. foliis cuneiformi-oblongis supra denudatis, $L y c h$ caule angulato paniculato. Jus.

V. Leaves zuedge-oblong.

WHITE MULLEIN. Sandy lanes, and road sides; very rare. Cliftou Hall. MARTYN.

$V$. foliis ovato-oblongis subserratis utrinque pulverpulverulentis, caule tereti paniculato. ulentum.

$\checkmark$. Leaves egg-oblong, Jomewhat ferrated; powdery on both fides.

V. Lychnitis, Var. 1. With.

YFILOIV IOARY MULI.EIN. NORFOLK MULLEIN. Banks and hedges in a gravelly or calcareous soil; rare. At Wollerton. PAY. B. July.

$V$ foliis oblongo-cordatis petiolatis undulato- nigrum. crenatis subpubescentibus. 
V. Leaves heart-oblong, on leaf-ftalks:

DARK or BLACK MULI.EIN. Helges and road sides. In plantations at hufford, belonging to the Hon. Richard Lumley Saville; Wollaton, rear Nottingham; and near Mansfield; upon the Forest near Clipstone Water.

P. July, August.

HYOSCYAMUS. Smili. 254. With. 252.

Cor. infundibuliformis, obtusa, irregularis. Stam. inclinata. Caps. operculata, bilocularis.

Bloss. Funnel-ghaped, blunt, irregular. Stam. leaning. Caps. with a lid, 2-celled. Seeds many, kidney-Jhaped.

niger. H. foliis amplexicaulibus sinuatis, floribus sessilibus.

H. Leaves embracing the fiem, indented: flow. ers fitiing.

COMMON HEX BANE. In villages, road sides, and among rubbish; on dunghills. Newark; Southwoll.

A duly,

ATROPA. Smith. 255. Whthering. 2.52.

Cor. campanulata. Stam. distantia. Bacca supera, bilocularis.

Bloss. bell-fhaped. Stam. diflant. Berry globular, 2-celled.

Bella- A. caule herbaceo, follis ovatis integris.

donna $A$. Stem herbaceous; leaves egg-flaped; entire.

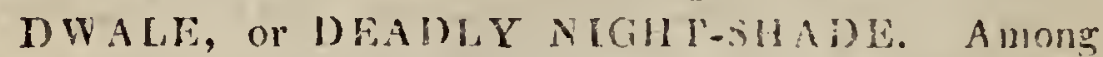
limestone, and rubbish. Store quarries, at Mlansfeht. Upon Clifton Rock, near Totinghan, facing ilie river. Drensac. In foure 1806 , I madic a iruitless search after this ylant at Clitun: and was informed that the plants had, on aceount of their peisonous qualities, been eradicuted

1. june, 


\section{SOLANUM. Smith. 256. With. 253 .}

Cor. rotata. Anthera subcóalita, apice poro gemino dehiscentes. Bacca supera, bilocu. laris.

Bloss. Wheel-haped. Anthers a little united, 2 holes at the top of each. Berry 2-celled.

S. caule inermi frutescente flexuoso, foliis Dulcasuperioribus hastatis, racemis cymosis.

S. Stem without prickles, rather Jhrub-like, zigzag : upper leaves halberd-Jhaped: flowers in tuft-like bunches.

WOODY NIGHT-SHADE. BITTER-SWEET. Herlges and sides of ditches. Hedges by the sides of the Old Trent Jitches, beyond Newark Bridge; Southwell.

S. June', July.

S. caule inermi herbaceo, foliis ovatis denta-nigrum. to-angulatis, umbellis lateralibus nutantibus.

S. Stem without prickles, herbaceous: leaves egg-Gaped, toothed, angular: bunches nod. ding, pointing 2 ways.

COMHON, or GARDEN NIGHT-SUADE. In kitchen gardens, amongst rubbish, and on dunghills. Sonthwell; Newark: by the side of the road from Cullingham to Besthorpe, in great abun'ance.

A. June---Sept. CHIRON!A. Smith. 257. With. 254. Cor. hypocrateriformis. Stam, tubo inserta. Aniherce demum spirales. Stylus declinatus. Pericarpium superum, valvulis inflexis bilo. culare.

-Bloss. Funnel-ghaped: piflil leaning. Stam. fixed to the top of the tube of the bloffom: Anthers becomiag Jpiral. Seed.vess. 2selled. 


\section{PENTANDRIA. MONOGYNIA. Samolus.}

Centau-C. caule herbaceo dichōtome paniculato, forium. liis ovoto-lanceolatis, calyce tubo breviore. C. Stem herbaceous: leaves Spear-Jhaped: calyx Jhorter than the tube of the blofjom.

COMMON CENTAURY. Barren pastures, particularly in a clasey soil. Borders of cornfields abont Southwell, plentifuliy; Eperstone Wood; by the sille of the road from Southxell to Kirkington; Close at Halam Beck, near Southwell, with ChLora Perfoliata; 'on Mr. Denison's new road, leading from Carltonupon-'Trent to Ossington.

Var. I. Flowers white; about Sonthwell, Rey. J. T. Becher; near Ossington, Rev. J. Charlez: worth.

SAMOLUS. Smith. 259. Withering. 246.

Cor. hypocrateriformis, quinquefida, squamis interstinctis. Stamina tubo inserta, laciniis opposita. Caps. seminifera, unilocularis, quinquedentatus.

Bloss. falver - Jhaped. Stamens protected by the valves of the bloffom. Caps. 1-celled; beneath; opening with 5 values at the top.

Valeran-S. foliis obtusis, racemo multifloro, pedidi. cellis bracteolatis:

S. Leaves blunt; bunches mauy-flowered; fruit-ftalks with florel leaves.

BROOK-WEED. WATER PIMPERNEI. Marshes and moist meariows, brook and runing waters. -Parks at Southwell; in a Ditch under Lady-Wood, between Ossington and Scarthingmoor Inn, ncar Tuxford.

P. June, July.

LONICERA. Smith. 260. With. 246.

Cor: monopetala, irregularis. Bacca polysperma, infera. 


\section{PENTANDRIA. MONOGYNIA. Rhamuus. 79}

Bloss. 1 petal, tubular, irregular. Berry beneath; 1 to 3 celled; many feeded.

L. capitulis ovdtis imbricátis. reminalibus, Pericly- foliis omnibus distinctis deciluis floribus menum. ringentibus.

L. Heads erg-fiuped, izlea, terminaling: leaves diftenct, deciduous: bloffom gaping.

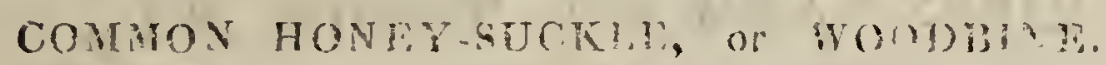
Hedger; comnon. Southeli, F. Jute. Jily.

RHAMNUS. imith. 261 . With. 256.

Cal. urceolatis. Petnla 5, staminibus opposita. Bacca supera,

Calyx tubular; fiales protecting the stamens. Bloss.'none; fruit a drupa.

R. spinis terminalibus, floribus quadrifdis cathardiocicis, foliis ovatis, caule erecto, bacca te- tacas. trasperma.

R. Thorns terminating: flowers \& cleft, male and female on different plants : leaves eggShaped: Atem upright.

- BUCKTHORN. Woods and hedges. In Hedges abont Basferd, and Bulwell; also in ifolne-lane, in a Hedoge by the Foot-way leading thence towards Nottingham.

S. May, Jusc.

EUONYMUS. Smith. 262. With. 259.

Cal. planus. Petala 5. Caps. pentagona, quinquelocularis, quinquevalvis, colorata. Sem. calyptrata,

Bloss. 5 petals. Caps. coloured; 5-fided, 5celled, 5-valued. Seed-coat. hollow. Seed veiled. 
euro- E. floribus, plerisque quadrifidis, petalis acu. paus: tis, ramis lævibus.

E. Flowers moftly 4-cleft: leaves fitting.

SJINILE-TREF. PRICKWOOD. Woods and Hedges; not common. Normanton Holt side, vear the Water-mill, ind in Dir. Bucklow's Peppermint Garden, Southwell.

S. May.

RIBES. Smith. 263 . Withering. 264 .

Cal. superus, campantalutus, quinquefidus. Pelala et Stamina calyci inserta. Stylus bifidus. Basca polysperma.

Petals 5. they and the Stamens fixed to the ca. lyx. Style cloven. Berry bineath, 1-celled, many-jeeded.

* Inermia.

1 Without prickles.

rubrum. R. inerme, racemis glabris pendulis, floribus planiusculis, petalis obcordatis.

R. Bunches /mooth, pendant: flowers flattifh.

COMMON CURRANTS. Wools and hedges. In $x$ hedge near Papplewick Bridge, in the road to Linhy; also at Basford.

8. Nliy.

nigrum. $\mathrm{R}$. inerme, racemis pilosis pendulis pedunculo simplici ad basin, floribus oblongis.

R. Bunches hairy, flowers cblong:

BLACK CURRAYTS. Wet hedges and banks of rivers: with $R$. rubrum. In a Hedge near Papplewick Cridge.

S. May.

* Aculeata.

2. With prickles. 
R. ramis aculeatis, petiolis pilosis, peduncu. Grosiulis unifloris, bracteis binis, fructu hirsuto. laria.

R. Branches prickly: fringe of the leaf-Alalk hairy: berraes hatry..

ROUGH GOOSHBRRY. In hedges. Southell.

E. April.

HEDERA. Smith. 267. With. 267.

Cal. quinquedentatus, Petala 5, basi dilatata.

Bacca pentasperma, cályce cincta.

Petals 5, oblong. Berry 4 or 5.celled; 3 to 5. feeded: juicelefs, encircled by the calyx.

H. foliis ovatis lobatisque.

Helix.

H. Leaves, fome egg-nhaped, others lobed.

COMMON IVY. Woods, hedges, aml old butldinge. Sonthwell latice; Ruins of the Cuside, Newark.

VINCA. Smille 269. With. 288.

Cor. contorta, hyprocrateriformis, infera. Folliculi duo, erecti. Semina nuda,

Bloss. falver-fhaped. Seed-vess, 2 upright lit. tle bags. Sceds naked.

$\mathrm{V}$ : caulibus procumbentibus, folis elliptico. minor. Janceolatis margine glabris, floribus pedunculatis, dentibus calycinis lanceolatis.

V. Slems trailing: leaves fpear egr-fhaped: flowers on frut.jtalks.

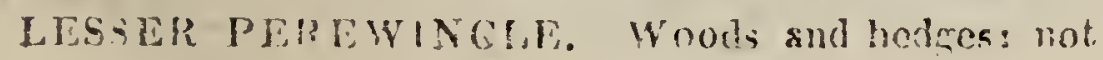
common. On Edingley Ilil, near Famste!d: Malan libil, near sourbiell.

P. Ilizy.

V. caulibus crectiusculis, foliis ovat is ciliatis, major. floribus pedunculatis, dentibus calycinis setaceis clongatis. 
82 PENTANDRIA. DIGYNIA. Herniaria.

V. Stems upright: leaves egg-jhaped: flowers on fruit-jtalks.

GREATER PERIWINCLE. Woods and hedges. In Xirklington Woods.

1.. May.

\section{DIGYNIA.}

HERNIARIA. Smith. 271: With. 269. Cal. quinquepartitus, inferus. Cor. nulla. Semina squamis 5 , filiformibus interjectis. Caps. monosperma calyce tecta.

Cal. zuith 5 divisions. Bloss. none. Stam. 5 perfect, and 5 imperfect. Caps. 1. jeeded.

glabra. H. glabra herbacea.

\section{H. Plant smooth.}

SMOOTH RUPTURE WORT. In gravelly soils. Qunce Close, wear Newark; and sandy closes thence towards Ilawton.

P. July, Augist.

CHENOPHODIUM. Smith.272. With. 270. Cal. quinquepartitus, inferus. Cor. nulla. Semen unicum, lenticulare, calyce clauso, pentagono, tectum.

Cal, with 5 clefts and 5 ribs. Bloss. none. Seed 1, round but flalted, fuperiour, horizonlal, covered by the clofing calyx.

* Foliis angulosis.

- Leaves angular.

Bonus C. foliis triangulari-sagittatis integerrimis, spiHenricus. cis compositis aphyllis. 


\section{PENTANDRIA. MONOGYNIA. Chenopodium. 83}

C. Leaves triangular-arrow-Shaped, very entire: Spikes compound, leaflejs : auxillary.

PERENNIAL GOOSE-FOOT. MERCURY GOOSEFOOT. Among rubbish; on road sides and walls; sometimes in pastures. In Southwell Church-yard.

P. May---Aug.

C. foliis rhomboideo-triangularibus sinuato- rubrum. dentatis, racemis erectis compositis foliolofis.

C. Leaves heart-triangular, rather blunt, and toothed: bunches upright, compound, forzewhat leafy, firorter than the ftem.

RED GOOSE-FOOT. Dunghills, rubbish, and culitvated ground. Sruthwell; Mansfield; Newark.

A. August.

C. foliis ovatis nitidis acutis dentatis, race- murale. mis ramosissimis cymosis aphyllis.

C. Leaves egg. Shaped, Jhining, toothed, acute: bunches branching, leafles.s.

NETTLE-LEAVED GOO3E-FOOT: Dunghills and rubbish.

A. Aug. Sept.

C. foliis rhomboideo-ovatis erosis postice in- album: tegris : superioribus oblongis integerrimis, seminibus lævibus.

C. Leaves diamond-triangular, gnawed, entire behind; the uppermoft oblong: bunches upright.

WHITE GOOSE-FOOT. Cornfelds, ols dunghilis, rubbish, and gardens; common. Sounwell; Newark; Manztield.

* Foliis integri6.

s Leaves entire. 


\section{PENTANDRIA DIGYNIA. UlmUS.}

olidum. C. Folits rhombeo-ovatis integerrimis, race. mis coliglomeratis.

C. Iearies viry entive. diamond.egg - Ghaped; fluzuers congregated auxillary.

Ch. Vulvaria. LINN.

ST!Y

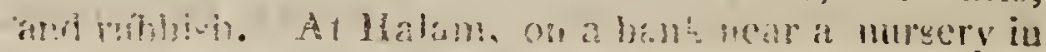

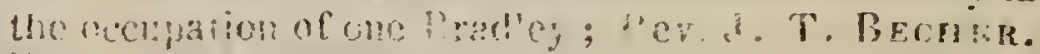

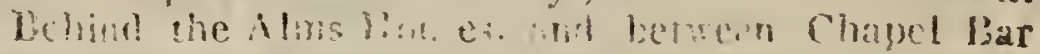

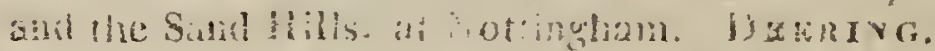

A. Aightist.

ULIUS. Smith. 281 . With. 278.

Cal. quirquefiche, infera, periters Cor. nulla. Caplula nerubranacea, compresso. plana, monosperma.

Ca1. 5.chalt. Blose. none. Caps. Ruperiour, 1-celled; leaflike and compreffed. Secd folztary.

campes-U. foliis Juplicatu-serratis scabris basi inætris. qralibus, Rurthus subsessilibus congestis.

U. Leaves doubly ferrated, unequal at the bufe: ficicers almolt fitting, crowded toge. ther.

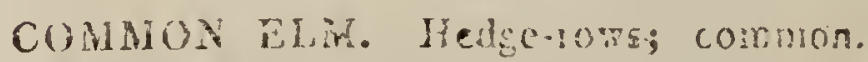

T. Alu?!, My.

monk - U. follis duplicato-scratis acuminatis has in.

nat. aqualibus, lloribus pedunculatis efrisis.

U. Leaves doubly Ferrated. imequal at. the bafe, egu. Fraped, but taper pointed; fincoth.

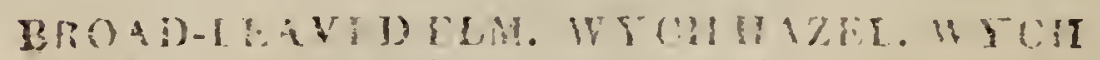

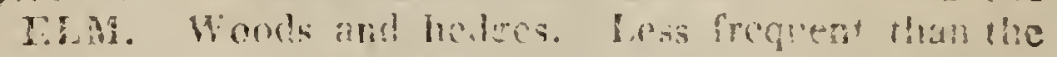

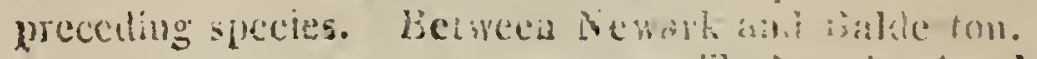

To- Hawh Apro. 
CUSCUTA. Smith. 28z. With. 209.

Cal. 4 vel 5 -fidus, inferus. Cor. monopetala, 4 vel 5 -fida. Capfula bilocularis, basi circumscissa. Sem. bina.

Cal. 4 or 5 -cleft. Bloss. 1 petal. Caps. 2-celled, cut round. Seeds in pairs.

C. floribus sessilibus, staminibus basi squama Epithycrenata munitis, stigmatibus acutis.

C. Flowers fiting, 5-clefted; furrounded by floral leaves.

LESSER DODDER. Cornficlds and heaths; not very coinmon. Southwell.

P. August.

GENTIANA. Smith. 284. With. 280.

Cor. basi tubulosa; poris nectariferis destituta. Caps. supera, unilocularis, bivalvis, polys: perma.

Bloss. 1. petal. Recept. of the feeds, $\mathbf{x}$, placed length-ways. Caps. 2-valued, 1-celled.

G. corolla campanulata quinquefida, floribus Pneumo- pedunculat is, foliis linearibuis. nanthe.

G. Bloffoms 5-cleft; bell-ghaped; on fruitfalks: leaves frap Fhaped.

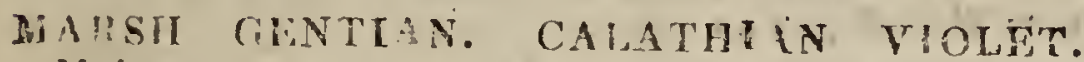
Inolsi heaths. On the Mons of bangford and staplefort, abundantly. A varey with wite fowers, is found on these nuors.

P. Auglist, sept.

G: corolla quinquefida, hypocrateriformi Amarel. fauce barbata, laciniis calycinis æqualibus. la.

G. Bloffoms 5-cleft, fatver-flabed: mouth bearded: calyx Jeyments equal. 
86 PENTANDRIA, DIGYNIA. Hydrocotyle.

AUTUMVAL GENTIAN. Dry pastures. mostly on oulcareous soils. About Kirklington Tenuple; among limestone rocky ground about Mansfield, pleimiully.

A. August.

campes- G. corolla quadrifida hypocrateriformi fauce tris. barbata, laciniis caylcinis exterioribus max. imis.

G. Bloffor 4 or 5-cleft: mouth bearded: ca. lyx Jegments, 2 of them larger:

JIELD GENTIAN. Mountainous pastures; rare; on the sides of the hills by the roarl from Marlihina Boor to Great Markham, near Tuxford.

A. Sept.

HYDROCOTYLE. Smith. 290. With. 284:

Umbella simplex. Invol. tetraphyllum. Petala integra. Fructus orbiculatus, compressus.

Umbel fimple, on a foot.faik. Involucr. of 2 or 4 leaves. Petals entire. Fruit compreffed, bulging, divifible into 2 parts.

vulgaris. H. foliis peltatis, umbellis quinquefloris.

H. Leaves target-Jhaped, notched: umbels 5flowered.

MARSH PENNYWORT. WHITE-ROT. Marsiy grounds and ditches. In the Quonce-hill Close, near Newarl; Old Trent Ditches beyout the Bridge, particularly about Fidler's Bridge, on the Foot-road to Kelham; Marshes about Papplewick; Basford scottun; Gravel-pits on Edingley Noors. P. Niay, Junc.

inunda $\mathrm{H}$. foliis pinnatis incisis, submersis mutifidotum. capillaceis; umbellis quinquefloris binatis.

H. Creeping: leaves under water, hair-like; those above, winged: umbels of 2. Spokes. Sison inundatum. LIN N. With. 
PENTANDRIA. DIGYNIA: Sanicula.

Fl.OATING WHITE-POT. Ditches, pools, and ground subject to inundation ; not frequent." Gravel pits near Kirklington Mill.

B. May.

SANICULA. Smith. 291. With. 284 :

Umbell.c confertæ, subcapitatæ. Petala inflexa. Fructus setis uncinatis muricatus. Flores disci abortientes.

Umbellules crowded, forming a kind of. head. Florets of the centre barren. Fruit Jet with hooked prickles.

S. foliis radicalibus simplicibus, floribus omnibus sessilibus.

S. Root leavies fimple: florets all fitting.

WOOD SA N!CLF. Woods and thickets. In the Thickels near Oxton Tull-jar: Westhorpe Dumble, near Southwell; Halam and Jdingley Hills, near Farusfield; and in the fullowing Woods, Kneeton, Flintham, Ossingron, Wernhan, Colwick, Broxtow, Lounds, Fak-

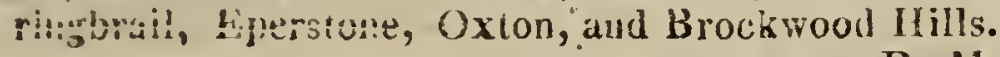

P. May.

CAUCALIS. Smith. 296. With. 287.

Involucra indivisa. Corolla radiata. Flores disci masculi. Frucius subovatus, striatus, setis rigidis muricatus.

Blossom radiated. Florets of the cenire male. Involucr. leafts entire. Petals bent inwards. notched at the end. Seeds covered with prickles or briftles.

C. umbellis multifidis confertis, involucro Anthris. polyphyllo, foliolis pinnatifidis, ramis erec- cus. tiusculis.

C. Seeds oval, rough on the back, with fcattered prickles. LinN. Involucrum many- 
leaved: Seeds egg-Shaped: Ayles reflected: leaves doubly compound: the terminating leafit Srap-Spear-Shaped. A IT. H. KEW.

UPRIGHT HEDGE-PARSLEY. Hedges, common. Southwell; Newark.

DAUCUS. Smith. 300. With. 289.

Involucra pinnatafida. Corolla subradiata. Fruclus múricatus.

Bloss. fomewhat radiated, (generally) all the florets hermaphrodite. Leafits of the involu. crum divided. See is with membranaceous toothed ridges.

Carota. D. fructibus hispidis, petiolis subtus nervosis.

D. Angles of the feeds 4, diflant, hifpid: leaf-ftalks fibrous underneath: umbel concave when in feed.

WILb CARROT. Borilers of fields, and heige banks; common. Southwell; Newark; Nottingham; Wansfield.

B. June, July.

BUNIUM. Smith. 301. With. 291.

Corolla uniformis. Uirbella conferta. Fructus ovatus.

Bloss. uniform. Umbel crowced. Styles bent back, deciduous. Seeds rather cylndrical, fored, thicker lowards the end.

Aexuo- B. involucro subtriphyllo, caule basi aphyllo fum. attenuato flexuoso.

B. Involucrum from 1 to 3 leaves, deciduous: fem leafless at the bafe, tapering downwards, zig-zag: Ayles permanent.

COMHON EARTII-NUT. KIPPER, or PIG-NUT. Meadow and pastures; frequent. Newark; Southwell.

P. May, June. 


\section{PENTANDRIA. DIGYNIA. Conium. 89}

CONIUM. Smith. 302. With. 292:

Involucella dimidiata, subtriphylla. Fructus ovatus, gibbus, utrińque quinque-costatus ; costis ante maturitatem crispis. Yetala zqualia.

Involucellum going half-way round, of abouk 3 leaves. Fruit egg-fhaped, bulging, ribs compreffed, waved before the fruit is ripe.

C. seninibus inermibus, caule ramosissimo macua nitido maculato.

C. Seeds without prickles: Atem greatly branched, Jmooth, Jpotted.

COMMOA HEMLOCK. Hedges, orchards, rubbish, and cultirated ground. Nerark; Southwell. P.July.

PEUCEDANUM. Smith.304. With. 294.

Fructus ovatus, utrinque striatus, ala cinctus. C'aly $x$ quinquedentatus. Involucra brevissima. Flores disci abortivi.

Involucrums very fhort. Fruit elliptical, Jightly ridged, comprefled and bordered.

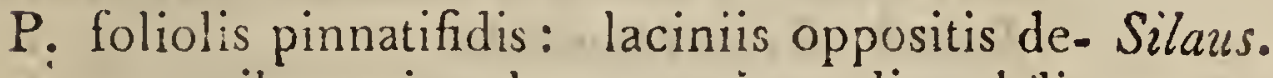
currentibus, involucro universali subdiphyllo.

P. Leafts wing-cleft: segments opposite: involucrum of 2 leaves.

MEADOW SAXIFRAGE, or SULPHUR-WORT. Moistish meadows and pastures. In the Meadows of Newark, and in $\Lambda$ rerham Meadow.

DEERING mentions P. OFFICINALE, as growing in Colwick Wood; which is so manifest an error, that I should not have hestowed an observation upon it, did I not find the same habitat given to the same plant in 'Tumer's Botanist's Guile, with the name of MARTY N subjoined as an authorily.

P. August. 
9o PENTANDRIA. DIGYNIA, Heracleum.

HERACLEUM. Smith. 306. With. 295. Fructus ellipticus, emarginatus, compressus, striatus, margine dilatatus. Flores radiantes. Petala inflexo-emarginata. Involucrum caducum:

Involucr. Jhedding. Bloss. irregular. Petals bent inwards, notched at the end. Seeds compreffed, leaf.like, Jmooth, encompaffed by a narrow membranaccous border.

Sphon. H. foliis pinnatis: foliolis pinnatifidis incisis dylium. serratis:

H. Leafts wing-cleft, even: flowers radiated:

COMMON COW PARSNEP. HOGWEED. In hedges, meadows, and pastures; common. Southwell; Newark.

B. July.

ANGELICA.. Smith. 311. With. 297.

Fructus subrotundus, solidus, utrinque trialatus. Calyx quinquedentatus. Corolla æquales. Petala incurva. Styli reflexi.

Bloss. equal. Petals bent inwards. Styles reflected. Fruit roundish.

sylves-A: foliolis æqualibus ovatis serratis.

tris.

A. Leafits equal, egg-Spear-Shaped, Jerrated.

WILD ANGELICA. Marshy woods and hedges; not uncommon. Westhorpe Dumal, near Southvell; Fperstone Wood.

P. July.

SIUM. Smith. 312. With. 298.

Fructus subovatus, compressus, striatus. Involucra polyphylla. Petala cordatá, uniformia. Involucrum many-leaved. Petals heart-Jhaped. Styles bent back. Fruit roundish. 
S foliis pinnatis: foliolis oblongo-lanceolatis latifoaqualiter serratis. lium.

S. Leaves winged: leafits egg-pear-Jhaped. regularly and Sharply ferraled; the terminating leafit 3 -cleft: umbels terminating.

BROAD-LEAVED WATER PARSNIP. RIVES and deep ditches; not frequent. Old Trent Biches, near Averham lieadows; Bunks of the Greet, near Southwell.

P. July, August.

S. foliis pinnatis: foliolis inæqualiter lobat is anguftiserratisque, umbellis pedunculatis oppositi- folium. foliis, caule erecto.

S. Leaves winged, leafits irregularly jagged and ferrated: involucruin wing.cleft: umbels on fruit-ftabls, auxillary.

NARROW-LEAVED WATER PARSNEP. IU ditches and rivulets; with S. nodiforum. In Ditches near Newark Bridge, and in the Purks at Southwell.

P. Juity, August.

S. foliis pinnatis, foliolis ovatis æequaliter ser- nodifloratis, umbellis scssilibus oppositifoliis, caule rum. procumbente.

S. Leaves winged; leafits tooth. ferraled: umbels lateral, oppofite the leaves, futting or on fruit-ftalks.

CREFPING WATER PARSNEP. In rivers and ditches. Edingley Moors; Ditches in the Parks at Southwell; and by the side of the Road from Newirk Bridge to Kelham.

P. July, August.

SISON. Smith.315. With. 300.

Fructus ovatus, striatus. Involucra subtetraphylia. Petala lanceolata, inflexa.

Involucrum about 4 leaves. Fruit egg-Jhaped. fiored. Styles bent back. 


\section{$9^{2}$ PENTANDRIA. DIGYNIA. Enanthe.}

Amo- S. foliis pinnatis, umbellis erectis subquadri. mum. radiatis.

S. Leaves winged: umbels upright.

HEDGE HOKLIVORT. BASIARD-STONR PARSLEY. Woods and hedger; wot very common. Sonthwell; Newark.

CENANTHE. Smith. 317. With: 301.

Flosculi difformes; disci sessiles, steriles. Fructus calyce stylisque coronatus, contice suberoso.

Florets of different fnapes, thofe in the centre fiting, barren. Fruit with a cork-like coat, oblong, fcored; crowned by the fylles and the calyx, which are permanent.

fistulo- E stolonifera, folitis callinis pinnatis filifor. sa. mibus, fistulosis, involucro universali sub. nullo.

CE. Jending forth Juckers: Jtem leaves winged; thread-Jhaped; hollow.

COMMON' WATER DRO'-WORT. Ponds and ditches; frequento Nerark and Averham Meadows; Meadow near the Cotton-mill at Southwell

P. July, Angrst.

peuceda.. CE. foliolis omnibus lineraribus, involucro mfolia. nullo, tuberibus radicalibus ellipticis sessilibus.

OE. Leafits all linear; general involucrum none: knobs of the root Jeffile, elliptical. ENGLISH BOTANY.

SULPIUR-WORT'. WATER DROP-WORT. SlOW streams, pounds, and ditches; bot very common. Halam Botons, and abont the Cottorsmill at Southwell. I'. July.

PHELLANDRIUM. Smith. 321. With. 303 . 
Flofculiomnes fertiles; disci minores. Fructus ovatus, lævis, calyce stylisque coronatus. Cential florets fmalleft. Fruit egg-ghaped, finooth, crowned with the pifil and the calyx.

P. foliorum ramificationibus divaricatis.

P. Ramifications of the leaves fraddling.

aquati-

cum.

WATER-HEMLOCK. In river, ditches, and pools; not common. Ditches in Mr. Bell's elose, on the way to Averham Meadow's; and near the River Trent, in Newark Meadow.

B. June, July.

CICUTA. Smith. 322, With. 304 .

Fruclus subovatus, sulcatus. Corolla regularis.

Fruit nearly egg-Jhaped; ribbed.

C. umbellis oppositifoliis, stipulis petiolo ad. virosa. natis obtusis.

C. Umbels opposite the leaves: leaf-galks bor. dered, blunt.

WATYR-HFMLOCK. WATLR-COWBANR. Siles of pools ind rivers; frequent. Southwell: sewarli.

P. August.

ETHUSA. Smilh. 323. Witi. 3०4.

Fructus striatus. Involucella dimidiata, triphylla, pendula.

Involucellums reaching half-way round, 3 leaved, bent downwards. Fruit nearly giobular, deeply furrozued.

CE. foliis conformibus.

Cynapi-

E. All the leaves alike, fruit nearly globular. um.

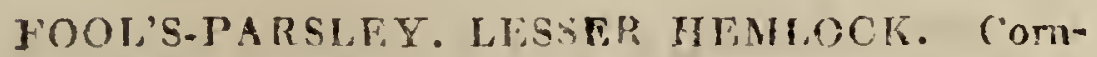
fielia, hedze banks, and kitchen gälen; common. Southwell; Newark.

A. August, segt. 
94 PENTANDRIA. DIGYNIA. Scandix.

SCANDIX. Smith. 323 With. 306.

Flores radiantes. Petala emarginata. Fructus subulatus. Flores disci sæpe masculi.

Bloss. radiated. Central Florets frequently male. Petals notched at the end. Styles permanent. Fruit awl-ghaped.

Pecten. S. seminibus longissime rostratis scabriuscu$V$ eneris. lis, foliólis lineari-multipartitis.

S. Seeds with a very long beak: leafits with many fine divisions.

NEHDLE-CHFPVII. TENUS'S-COMB. SITEP. PHEliD's NELDLE. Corufields; common. Southwell ; Newark.

A. June, July.

Anthris-S. seminibus ovatis hispidis, corollis uniforsus. mibus, caule lævi.

S. Seeds egg-fraped, rough with hair: blos. soms uniform: ftem finooth.

- Caucalis scandicina. With.

ROUGH CHERVIL. Hedges and meadows. On vottinghan Caslle Rock.

A. May.

CHEROPHYLLUM. Smith. 325. With. 308.

Petala cordata. Fructus oblongus, læviuscu• lus. Involucella reflexa, concava.

Involucellum reflected, concuve. Petals heartGraped, bent inwards. Fruit Jhining, generally finooth, oblong.

sylues- C. caule striato lrvi, geniculis tumidiuscu. bre. lis.

C. Stem fmoothish, fcored, a little fwallen at the knots. 


\section{PENTANDRIA. DIGYNIA. Pastinaca。 $9^{5}$}

SMONTH COW-PARSLEY. WILD CHERVIT. Hedges; orchards and pastures; common. Southwell; Newark.

P. April, May.

C. caule scabro, geniculis tumidis. temuler.

C. Stem fpotted, joints fwollen: ftem and tum. lcaves rough: leafits cut, acuic.

ROUAH COW-PARSLEY. ROUAH CHERVIL. Herdges; common. Southwell; Mansfield; Nottinghan.

B. June, July.

PASTINACA. Smith. 328. With. 309 .

Fructus ellipticus, compresso-planus. Petala involuta, integra.

Petals rolled inwards; entire. Seeds elliptical compreffed, leat-like, Jmooth; border thin, narrozu.

P. foliis simpliciter pinnatis subtus pubescen- Jaliva. tibus.

P. Leaves fimply winged.

IFILD PARSNEP. Borders of ploughed fields, in limestone soils. Fy the side of the Road from Southvell to Averham, in many places.

B. July.

SMYRNIUM. Smith. 328. With. 310.

Fructus oblongus, angulato-costatus. Petala acuminata, carinata, incurva.

Petals keeled, tapering to a point. Fruit eggglobular, bulging, angular, with ribs.

S. foliis caulinis ternatis petiolatis serratis. Olus.

S. Slem leaves growing by threes; on leaf-ftalks; atrum. ferrated.

AlEXANDERS. Ditches and rocks; very rare. On Nottingtum Castle Rock.

B. Sixy. 
96- PENTANDRIA. DIGYNIA. Anethum:

ANETHUM. Smith. 329. With. 310.

Fructus ovatus, subcompressus, striatus. $P_{e-}$ tala invointa, integra.

Petals entive; rolled inwards. Fruit lentilShaped, but compreffed; finall, fcored, bordered.

Fanicu. A. fructibus gibbis, foliis caulinis numerosis lum. deflexis.

A. Leaves with many divifrons, hair-like: feeds egg-oblong, tapering at each end, not bordered.

COMMON FINAEL. Chalk clifs; rare. Nottingham Castle Rocks. B. July, iugust.

CARUM. Smith. 330. With. 311.

Fructus elliptico-teres, striatus. Petala carinata, inflexo-cmarginata. Involucrum univerfale sub-monophyllum.

Involucr. 1 leaf. Petals united, bent inward's, notched at the end. Fruit Jimall, elliptical, bulging, roundifh and fiored.

Carui. CARUM.

COMMON CARAWA T. Meadows and pastures; very rare. In that part of the meadow at Newark, near llate River Trent, facing the entrance gate. $\quad B$. Jube.

PIMPINELLA. Smith. 331. With. 311.

Fructus ovato-oblongus, striatus. Petala inflexa. Stiomata subglubosa.

Petals bent inwards. Styles upright. Summits nearly globular. Fruit finall, egg-ob. long: with 5 elevated ridges. 


\section{PENTANDRIA. DIGYNIA. Apium. 97}

P. foliis pinnatis : foliolis radicalibus subro-saxifratundis : summis linearibus.

P. Leaves winged: leaftis on the roct-leaves roundish, thofe of the upper ones Jtrab-Shaped.

COMMON BURNET SAXIFRAGE. Meadows and pastures ; in gravelly or calcareous soils ; not common. In Newark and Averham Meâdows; Quoisce Hill Close; Ldingley Hill; IIalam Hill

P. July, August.

P. foliis pinnatis : foliolis omnibus ovatis; magna. impari trilubo.

P. Leaves uniform, winged; leafits Spear-fhaped, irregularly ferrated; floral leaves wingcleft.

CREAT BURNET SAXIFRAGE. Woodsand hedges; in linestone. Ileilges about Southwell, and on the Toad from (x)ion to Southwcll; thickets near Oxton Toll bar; Eperstone Woods. P.July, August. APIUM. Smath. 333. With. 314.

Fructus ovatus, costatus. Pelala inflexa, æqualia. Involucrum monophyllum.

Involucr. 1. leaf. Petals equal. Fruit fimall, bulging, rabbed. Styles bent backwards.

A. foliolis caulinis cunciformibus, caule sul-graneocato. lens.

A. Stcin leaves viedgre. Ghaped.

SMALCACE. WILD CIILEYY. In ditcies and marilies. Ki k!ingion Toll-bar; Hatim croas; by the side of

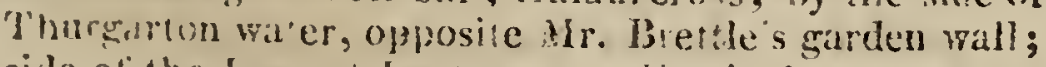
side of the Lecn at Lenton, near Nottingham.

P. Angust.

CEGOPODIUM. Smith. 33. With. 314: 


\section{PENTANDRIA. TRIGYNIA. Viburnum.}

Fructus ovato-oblongus, costatus. Petala inflexo-cordato, inæqualia.

Fruit egg-oblong, fcored'; tapering at each end.

\section{Poda- OEGOPODIUM.}

graria. OE. Upper leaves 3 together, lower ones in triple threes.

GOUT WEED. HERB GERARD. Hedges, orchards and pastures. Hedges about the Spring Gardens, near the Quonce Close, Newark, abundantly. P. May, June.

\section{TRIGYNIA.}

VIBURNUM. Smith. 334. With. 315.

Cal. superus quinquepartitus. Cor. quinque. fida. Bacca monosperma.

Cal. with 5 divisions, superiour. Bloss. 5 -cleft. Berry of 1 cell; closed. Seed 1.

Opulus: V. foliis lobatis, petiolis glandulosis.

V. Leaves lobed: l leaf-falks fet with glands.

COMMON GUELDER ROSE. WATER FLDER.

Woods and wet hedes; not common. Westhorpe

Dumal, near Southwell; Hockerton; Kirlilington.

S. J une.

SAMBUCUS. Smith. 335. With. 316.

Cal. superus, quinquepartitus. Cor. quinquefida. Bacca trisperma.

Cal. 5-toothed. Bloss. regular, with 5 Jhallow clefis. Berry juicy, clofed, many-Jeeded. 
PENTANDRIA. TETRAGYNIA. Parmassia. 99

S. cymis tripartitis, stipulis foliaceiș, caule Ebulus. herbaceo.

S. Tufts with 3 divifions: Ripula leaf-like: Aem herbaceous.

DWARF ELDER. DANE-WORT. Hedges; road sides; orchards: : rare. In Bennet's Hop Y ard Close, at Halan ; hy the side of the road at Gonalston Mill. At Gamston, aind in Bunny Lane. DeEring. P. July.

S. cymis quinquepartitis, foliolis ovatis ser- nigra. ratis, caule arboreo.

S. Tufis with 5 divifions: leaves winged: leufits nearly egg-Jhaped, Jerrated: ftem tree-like.

COMVMON FI.DER. Wonds and hedges; common: suuthwell; Nottinghanı; Maustield; Newark.

E. A pril, May.

B. Sambucus fructu albo.

WHITE-BERRLED ELDER. In Graves-lane, near Edingley.

\section{TETRAGYNIA.}

PARNASSIA. Smith. 339: With. 319.

Cal. quinquepartitus. Pet. quinque. Nectaria quinque, cordata, ciliata apicibus glo. bosis. Capfula quadrivalvis.

Cal. with 5 divifions. Petals 5 . Nectaries 5, heart-Shaped, fringed, with little balls on the top of the fringe. Caps. 4-valived. 1selled. Seeds witli a membranaceous border:

K. 2 


\section{Yoo PENTANDRIA. PENTAGYNIA. Linum.}

\section{palufris. PARNASSIA.}

P. Nectaries fimple.

GRASS OF PARNASSUS. Moigt meadows; somerhat rare. In the Parks at Southwell, and in the Meadow near the Water-mill; in a Close at Halum, with Pinguicula. Vulgaris. In the Lawn at Kirklington, the seat of Mrs. Whetham; Bleasby ; in the Dam Close at Papplewick.

P. Sept. Oct.

\section{PENTAGYNIA.}

LINUM. Smith. 339. With. 321.

Cal. pentaphyllus. Pet. quinque. Capfulco supera, decemvalvis, decemlucularis. Se. mina solitaria.

Cal. 5-leaved. Petals 5. Caps. 5-vatued, 10. celled. Seeds. folitary.

- cathar. L. foliis oppositis obovato-lanceolatis, caule ticum: superne dichotomo, petalis acutis.

I. Leaves oppofite, egg-ppear-Shaped: Rem forked: blossom pointed.

PURGING FLAX. Dry meadows and pastures; fre. quent. Newark; Arerham; Southwell.

A. June--- A ugust.

\section{HEXAGYNIA.}

DROSERA. Smith. 346 . With. 323.

Cat. quinquefidus. Pet. 5. Capfula unilucularis, trivalvis, supera, polysperma. 
PENTANDRIA. POLYGYNIA. Myosurus. 101

Calyx with 5 divifons. Petals 5. Caps. 1celled, with 5 values at the top. Seeds several, fixed to the sides.

D. foliis orbiculatis radicalibus, scapo race-rotundimoso. folia.

D. Stalks from the root: leaves circular. LIN . Styles 6. HuDs.

ROUND-LEAVED SUN-DFW: On mossy bogs, and moor grounds. Coddington; Stapleford and Langford Moors; Oxton Bottoms; Ediugley Moor.

P. July, August.

\section{POLYGYNIA.}

MYOSURUS. Smith. $34^{8}$. With. 326 .

Cal. pentaphyllus, basi appendiculatus. $P e t$. 5, ungue tubuloso, nectarifero. Semina numerosa, nuda.

C.al. 5 leaves, united at the bafe, deciduous. Nectaries 5, like petals; awl-Shaped. Seeds. numerous, coated, pendant.

MYSOSURUS:

MOUSE-TAII. Cornfields, in a gravelly soil; but not common. Among cornfields at Ujton near Southwell; At Coddington; and also in sandy ground belonging to. my friend Mr. Jacob Ordoyno, who has observed it there for several years. At Normanton, near Southwell, the Rev. J. 'I. B EcHER. 'This plant being an annual of humble growth, is frequently destroyed or buried for awhile by the operation of fallowing, so that it ocasionally disapuears.

A. May, June, 


\section{Classis VI.}

\section{HEXANDRIA.}

Stamina 6 .

\section{MONOGYNIA.}

\section{Stylus 1.}

* Fl. calycalati, calyce corollaque instructi.

1 Flowers with a cup and a bloffom.

BERBERIS. Cor. hexapetala. Cal. hexaphyllus, inferus. Bacca disperma.

BERBERIS. Bloss. 6 petals. Cal. 6 leaves; beneath. Berry 2.jeeded.

PEPLIS. Cor hexapetala. Cal. decemfidus. Caps. bilocularis.

PEPLIS: Calyx 12-cleft. Caps. 2.celled. * Fl. spathacei sive glumacei.

: 2 Flowers with a Sheaf or hufk.

GALANTHUS. Cor: supera, hexapetala; petalis tribus interioribus brevioribus, emarginatis.

CALANTHUS. Bloss. fuperior; of 6 petals ; 3 inner petals fhorler, and notched at the end.

NARCISSUS. Cor. supera, hexapetala. Nectarium campanulatum, petaliferum, stamina includens: 
NARCISSUS: Bloss. Superior; of 6 petals. Nectary bell-Jhaped; Jurrounding the ftamens.

ALLIUM. Cor. infera, hexapetala; petalis ovatis, sessilibus.

ALLIUM. Bloss. benealh; of 6 petals. Petals egg-Japed fiting.

*** Fl. Nudi.

3 Flowers naked.

CONVALLARIA. Cor. infera, sexfida. Bacca trilocularis. Stigma trigonum.

CONVALLARIA. Bloss. beneath; 6-cleft. Berry 3-jeeded.

NARTHECIUM. Cor. infera, hexapetala, patens. Sem. appendiculata. Stam. hirsuta.

NARTHECIUM. Bloss. 6 petals. Style none. Seeds with a tail at each end.

ORNITHOGALUM. Cor. infera, hexapetala. Stam. basi dilatata.

ORNITHOGALUM. Bloss. beneath; of 6 petals. Fildments every other broader at the bafe.

SCILLA. Cor infera, hexapetala. Stam. filiformia: SCILLA. Bloss. beneath; of 6 petals; deciduous: Filaments thread-Jhaped.

ACORUS. Cor. infera, hexapetala. Spadix multí. florus.

ACORUS. Spike-stalk many flowered. Caps. 1. celled.

*** Fl. incompleti.

4 Flowers without petals. 


\section{HEXANDRIA. TRIGYNIA:}

JUNCUS. Cal. hexaphyllus. Caps. supera, trivalvis, polysperma.

JUNCUS. Calyx 6-leaved. Caps. 1-celled.

\section{TRIGYNIA.}

Styli 3 .

COLCHIOUM. Cal. spatha. Cor. hexapetaloidea. COLCHICUM. Calyx a Jheath. Bloss. like 6 petals.

TRIGloChin. Cal. triphyllus. Pet. tria. Caps. basi dehiscens.

TRIGLOCHIN. Calyx 3 -leaved. Bloss. 3 petals. Caps. opening at the bafe.

RUMEX. Cal. triphyllus. Pet. tria. Sem. uni。 cum, triquetrum.

RUMEX. Calyx 3 -leaved. Bloss. 3 petals. Seeds

$1 ; 3$-cornered.

\section{POLYGYNIA.}

Styli plures.

ALISMA. Cal. triphyllus, Pet. tria. Caps, plures aggregatæ, monospermǽ.

ALISMA. Calyx 3 leaves. Bloss. 3 petals. S. Vess. Several. 
HEXANDRIA. MONOGYNIA. Galanthus. 105

\section{HEXANDRIA. \\ 1 MONOGINIA.}

GALANTHUS. smith. 353. With. 331. Cor. supera, hexapetala; petalis tribus interioribus brevioribus, emarg!natis. Stigma simplex.

Petals 3 , concave. Nectary 3 smaller petals notched at the end. Summit undivided.

GALANTHUS.

nivalis.

SNOWDROP. Meadows, orchards, and sides of hedges. Hoveringham.

P. February.

NARCISSUS, Smith. 353. With. $33^{1}$.

Cor. supera, hexapetala, xqualis. Nectarium infundibuliforme, monophyllum, petalife. rum. Stamina intra nectarium. Stigma tri.

- Eidum.

Bloss. superiour, of 6 equal petals. Nectary of 1 leaf, furrounding the ftamens, mostly funnel-fhaped.

N. spatha uniflora, nectario campanulato erec-Pseldoto crispo obsolete sexfido petalis ovatis narcis. xquali. sus.

N. Sheath 1 flowered: nectary bell haped, upright, curled; as long as the petals: petals egg-Jhaped.

COMMON DAFFODIL. In woods and meadows; not common. In a close behind the Thicket wear OXson Toll-bar.

P. March.

ALLIUM. Smith. 355. With. $33^{2}$. 
Cor. infera, hexapetala, patens. Spatha bi. fida, multiflora. Umbella congesta. Stigma simplex.

Bloss. 6 peials, expanding. Sheath dry and Jin-like, many-flowered. Umbel crowded. Caps. Juperior, 3-celled.

vineale. A. caule teretifolio bulbifcro, staminibus tricuspidatis.

A. Filaments 3.pointed.

CROW GARLICK. Meadows and pastmes. Nexark; and Averham Meadows, beyond the Cofton Mill, in * great abundance; Westhorpe, near Southwell. P. duly.

ursi- A. scapo nudo semicvlindrico, foliis lanceolayum. tis petiolatis, umbella fastigiata.

A. Stalk 3-quare: leaves /pear-Jhaped, on leaf-ftalks: umbel flat-topped.

BROAD-LEAVED GARI.ICK RAMSONS. Woods and hedges. Hedges on the left-hand about a mile from Southwell on the Nottingham. Roarl: and in the following Woods; Eperstone, Oxton, Colwick, Flinthan, Louncles, and Broxtow. P. May, June.

ORNITHOGALUM. Smith: 362 . With.

Cor. hexapetala, persistens, supra medium patens. Filamenta basi dilatata. Capjula supera, trilocularis. Semina subrotunda. Cal. 'nullus.

Bloss. 6 petals, upright, permanent, above the middle expanding. Filaments the alternate ones dilated at the baje. Caps. fuperior, 3-relled.

umbella- O. floribus corymbosis, pedunculis scapum tum. superantibus, filamentis subulato-dilatatis integerrimis. 


\section{HEXANDRIA. MONOGYNIA: Scilla. 107}

O. Flowers forming a corymbus ; outer fruitfalks taller than the central ones.

COMMON STAR OF BETHLEHEM. Woods. meadows and pastures; rare. In the fields on the left hand side of a small stream, near the foot-road leading from Kirkby to Kirkby Hardwick, plentifully, and apparently wild. Kev. J. 'T. BECHER.

P. April, May.

SCILLA. Smith. 366. With. 343 .

Cor. hexapetala, patens. Filamenta filiformia. Capfula supera, trilocularis. Semina subrotundá. Cal. nullus.

Bloss. bell-Shaped, permanent. Segments rolled back. Germen with 3 neclariferous pores at the top.

S. foliis linearibus, spica nutante, floribus nutans. cernuis campanulato-cylindricis apice reflexis, bracteis geminis.

S. Blo/s tubular.bell. Jhaped, with 6 divifions: jegments rolled back: floral leaves in pairs. Hyacinthus nonscriptus. LINN. With.

HARE-BELL-SQUILL. WILD HYACINTH. Woods and hedges. In Fiperstone, Flintham, Colwick, and Asply Woods; Thickets near Oxton Tollbar ; and Southwell.

P. May.

NARTHECIUM. Smith. 368. With. 339: Cor. hexapetala, patens, persistens. Filamenta filfiormia, hirsuta. Capsula supera, prismatica. Semina utrinque appendiculata. Cal. nullus.

Bloss. 6 petals, permanent. Style none. Caps: egg-Jhaped. Seeds lapering to each end. 


\section{HEXANDRIA. MONOGYNIA. Narthecium.}

\section{ossifra- NARTHECIUN.}

gum. Anthericum ossifragum: LINN.

LANCASHIRE ASPPODEL. Cn turf bogs; very rare. T'wo plants were found on Coddington Hioor, by Mr. JA $\cos$ ORDQY Yo.

CONVALLARIA. Smith. 370. With. 341 : Cor. sexfida. Cal. nullus. Wylus staminibus longior. Stigma trigonum. Bacca supera, trilocularis, ante maturitatem maculata.

Bloss. 6-clefi. Berry 3celled, Juperior. Seeds 2.

majalis. C. scapo nudo senicylindrico, floribus spicat is pedicellatis nutantibus.

C. Stalk naked: Jemi-cytindrical, flowers jpiked, nodaing.

LILY OF THE V HLEYY. MAY LILY. WOOdS aud lieaths. In a wood culled the Gieat Hood, atbout

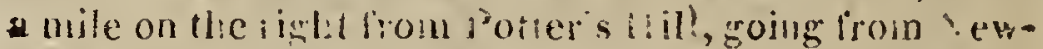
ark on $t$ ! e lintolin rond; in a valley at cockglode, near Ollertun, pientifully.

P. Hay.

ACORUS. Smilh 373. With. 343 .

Spadix cylindricus, tectu flosculis. Cor. hexapetala, nuda. ibylus nulius. Capsula trilocularis.

Spadix cylindrical, covereat with florets, Bloss. 6 pietals, natied. Siyle none. Caps. 3-celled.

Calamus. A. scapi mucrone longissmo foliacen. A. Floral latef wery muklonger than the filie.

SW WET t IAC. Pants of rivers with anudry hoitom. By the siste of the river Suar, in going to swarstose Bridge, flus Noltinghan, in severisl jilices. P. Suide. 
HEXANDRIA. MONOGYNIA. Juncus. 109

\section{JUNCUS. Smith. 374. With. $344^{.}$}

Cal. hexaphyllus, persistens. Cor. nulla. Capsula supera, trivalvis, uni-vel-trilocularis: Semina plurima. Stigmata tria.

Husk 2 leaves. Calyx 6-leaved, permanent. Bloss. none. Caps. superiour, 3-celled, 3 valved, many-seeded; or else-1-celled, and 3-seeded.

* Culmis nudis.

1 Straw naked.

J. culmo nudo stricto, panicula laterali con. congloglobata, capsulis retusis, floribus triandris. meratus.

J. Straw stiff and siraight: flowers in a lateralinead; egg-shaped, blunt, 3 stamens in each.

COMMON RUSH. Wet meadows and pastures; common.

P. July.

J. culmo nudo stricto, panicula laterali ef-effusus. fusa supradecomposita, capsulis obtusis.

J. Straw stiff and straight: panicle Tateral," loose: flowers egg-shaped, blunt, 3 stamens in each.

SOFT RUSH. Wet meadors and pastures: P. July. $*$ Culmis foliosis.

2 Straws leafy.

J. foriis nodoso-articulatis, capitulis panicu-articulalatis multifloris. tis.

J. Leaves with knot-like joints: flowers panicled: petals blunt.

JOLWTED RUST. Meadows and pastures. P. June, 


\section{HEXANDRIA. MONOGYNIA. Juncus.}

bulbosus. J. foliis linearibus canaliculatis, culmo basi folioso, panicula cymosa, capsulis obtusis.

J. Straw undivided, somwhat compressed: leaves strap-shaped, channelied: panicle terminating, shorter than the floral leaf: cups and capsules blunt.

ROUND-FRUITFD RUSH. Wet meadows and heaths; In Mr. Kirk's Greet Meadow at Normanton, near the foot-path; and in the Parks, aljoining tie Bleach-jarl close, Southwell. P.July.

bufonius. J. toliis linearibus canaliculat is, culmo dichotomo racemoso, florious solitariis.

J. Straw forked: flowers solitary, sitting: calvx leaftes spear-shaped, sharp-pointed: capsule egg-shaped, shorter than the calyx.

TOAD RUSH. We gravelly sandy meallows or pastures.

A. July, August.

pilosus. J. foliis planiis pilosis, panicula cymosa divaricata, floribus solitarils.

J. Leaves flut, hairy: corymbus branching. LIN N. Flowers solitary. HUD.

HAIRY RUSH. Woods; common. P. April, May.

sylva. J. foliis planis pilosis acuminatis, panicula ticus. cymosa decuinposita, floribus fasciculatis.

J. Leaves flat, hairy: panicle terminating, very much branched: flowers 1, 2, or 3 together.

J. maritimus. With.

WOOD RU'H. Woods and hedres; not common. Eperstone Wood. $\quad$ P. Mlay, june. campes. J. foliis planis pilosis, spicis terminalibus trzs. sessilibus pedunculatisque, capsulis obtusis. 


\section{HEXANDRIA. MONOGYNIA. Berberis, 11}

J. Leaves flat, somewhat hairy: spikes sitting, and on: fruit-slalks.

HAIRY-FIEID RUSH. Pastures, meadows and lieaths; common.

P. April, May.

BERBERIS. Smith. 387 . With. 351 .

Cal. hexaphyllus. Perala 6; ad ungues glandulis duabus. Stylus nullus. Bacca superd, disperma.

Calyx 6.leaved. Petals 6, with 2 glands to the claw. Style none. Berry superior, 1celled; open at the end. Seeds 2 or 3 .

B. floribus racemosis, spinis triplicibus, foli- vulga. orum serraturis aristat is.

ris.

B. Fruit-ftalks forming bunches; thorns 3 together.

BARBERRY. Woods and hedres; not common. Holt side, at Normanton, near Southwell; in a hedge about hatf-way. hetween heilord and Worksop, opposite Mr. Foljambe's house, at Osberton ; hedge in the churchyard at Holme Pierrepont, neat Nottingham; Fiskerton-uion-Trent.

S. May, June.

PEPLIS. Smith: 389 . With: 352 .

Cal. campanulatus, ore duodecimfido, Petala. 6, calyci inserta. Capsula supera, bilocularis.

Calyx bell-shaped, rim 12-cleft. Petals none, or 6. fixed to the cup. Caps. superior, 2celled, many-seeded.

P. floribus subapetalis foliis obovatis.

Poxicla.

P. Flowers often wathout petals: 
12 HEXANDRIA. TRIGYNIA. Rumex.

WATER-PURSLANE. Marshy and watery places, especially such as become dry in Summer. On the Moors of Stapleford, C'odilington, and Langford; Farasfeld Carr; Edingley Moor: 'A. July, Aug.

\section{TRIGYNIA.}

RUMEX. Smith. 390. With. 353 .

Cal. triphyllus. Petala 3, conniventia. Semon nnicum, triquetrum, superum, nudum. Stigmata multifida.

Calyx 3-leaved. Petals 3, closing. Seed 12 three-cornered, inclosed in the blossom.

* Elores hermaphroditici.

1 Flowers hermaphrodite.

sanguin. $R$. valvulis integerrimis oblongis, unica praeus. cipue granifera, foliis cordato-lanceolatis.

R. Valves very entire: leaves heart-spear. shaped.

BLOODY-VEINED DOCK. Wonts and road sides; not common. Farm yards at Munsfield. DeERing. MaRTYN.

crispus. R. valvulis ovatis integris omnibus graniferus, foliis lanceolatis undulatis acutis.

R. Valves strongly vieined: leaves spear-shaped, asute, waved and curled at the edge.

CURLF.D DOCK. Meadows, pastures, road sides, ą!d cultirated fround; il almost all soils; commou. P. June,July. 
R. valvulic oblongis subdentatis omnibus aculus. graniferis, foliis cordato-oblongis acuminatis, raremis foliolosis.

R. Values veinless : leaves oval-spear-shaped, uneven at the edges.

SMOOTH SHARP DOCK: Woods, hedger. road sides and rivers; sometimes in fields and meadow:; common.

P. July.

$R$. valvulis dentatis unica pracipue granifera, oblusi. foliis radicalibus curdatis ubiusis, caule folizs. scabriusculu.

R. Leaves heart-oblong, bluntish, finely notched.

BROAD-LEAVID DOCK. Among rubbish, farm yards, cuurts, and sides of ditches; common.

P. July, August.

$R$ : valvulis deltoideis setaceo-dentatis grani mariti. feris, fuliis lineaeribus, verticillis confertis. mus.

R. Leaves strap-shaped: flowers in distant whirls.

GOLDF.N DOCK. Road sicles and among rubhish ; not commnn:- By the side of the River l.een, at suenton, in going froin the Meadows to the Trent. DEERING MarYN. P. July, August.

R. valvulis ovatis integris obsolete graniferis, aquati. toliis cordato-lanceoldtis acutis.

cus.

R. Leaves spear-shaped, smooth, acule; very. entire, taperang at the base.

R. Hydrolapathum. Widh.

GR LA I' WATER-DOCK. Peat marshes; wet ditches, pools, and sides of rivers. Ldingley Noor.

P. July, August.

L. 3 . 
14 HEXANDRIA. TRIGYNIA. Triglochin.

$$
2 \text { * Fale and female flowers on distant planis: }
$$

Acetosa. R. floribus dioicis, foliis oblongis sagittatis. valvulis graniferis.

R. Leaves oblong, arrow-shaped.

COMMON SORREL. Meadows.and pastures : common.

Newark; Southwell; Mansfield; Nottingham.

$$
\text { P. June. }
$$

Acelo- R. floribus dioicis, foliis lanceolato-hastatis, sellia. valvulis grano destitutis.

R. Leaves spear-halbert-shaped.

SHEEP'S SORREL. Sandy meadows and pastures, in gravelly soil. Farnsfield;: Blidworth.

P. May, Junes

TRIGLOCHIN. Smith. 398. With. 359:

Cal. triphyllus. Petali tria, calyciformia. Sty. li nulli. Capsulice superæ, basi dehiscente. Semina solitaria.

Cal. 3-leaved. Petals 3, like a cup. Style none? Caps. opening at the base.

palustre. T. capsulis trilocularibus sublinearibus.

T. Capsule 3.celled, nearly strap.shiaped.

MARSH ARROW-GRASS. Wet meadows and pas. tures. In the Parks at Southwell; Ldingley Moor; Oxton sitews.

P. July.

COlCHICUM. Smith. 399. With. 359. Cal. spatha. Cor. sexpartita, tubo radicali. Capsua tres, supera, connexa, inflata, polysperma. 
FEXANDRIA. POLYGYNIA. Alisma. en

Caly $x$ none. Bloss. with 6 divisions. Tube very long, extending down to the root. Calys. 3. influted, unted.

C. foliis planis lanceolatis erectis.

C. Leaves.flat, spear-shaped, upright.

autumnale.

MFAIOOW SAFFRON. Meadows in a rich son!. In the Meadows at Newark, abundautly; in !loline Mcadows beyond Winthorpe, near the Kiver; In the Meadows at Winkburn, the seat of Peter Pegge Burnell, Esquire.

i'. september.

\section{POLYGYNIA.}

ALISMA. Smith. 400. With. $3^{5}$.

Cal. triphyllus. Petala tria. Capsula plures, aggregatæ, submonospermæ.

Calyx 3 -leaved. Petals 3 . Seeds many.

A. foliis ovatis acutis, capsulis obtuse trigonis. Planta-

A. Leaves egg-shaped, acute: fruit with 3 go. blunt corners.

GREATER WATER PLANTAIN. Ditches and watery places. In the Old Trent Ditches about Newarik, by the Road side.

P. July.

A. foliis lineari-lanceolatis, capsulis pentago- ranun. nis incurvis gluboso-aggregatis.

culurdés.

A. Leaves sirap-spear-shaped, on leaf-stalks: fruzt glovular, scurfy.

SMAIL- MAIER PLA YTAIN. Wet turfy bogs. In old riratel-pits :ear Kirklington Nill; on Fdingley Moor; in a Ditch near a Cottage on Langford Moor Trent side, between Clifton-IIill and Nottityham. DEERING.

P. August. 


\title{
Classis VIII.
}

\section{OCTANDRIA.}

\author{
Stamina 8.
}

\section{MONOGYNIA.}

\author{
Stylus 1.
}

* Fl. completi.

1 Flowers complete.

ACER. Pet. quinque. Cal. quinquefidus, inferus. Caps. monospermæ, alatæ.

ACER. Male flowers many: Bloss. 5 petals. Cal. 5 -cleft. Capsules 2 or $y$; 1 . seed an each'; winged: wuth a membrane at the end.

EPILOBIUM. Pet. quatner. Cal quadrifidus, superus. Caps. quidrilocutaris: Sem. papposa.

EPILOBIUM. Bloss. 4pelals. Cal with + divisions, superzaur. Cáps. 4-celled. Seeds aowny.

CHLORA. Cir. octopartita. Cal. octophyllus, inferrs. Caps. unilocularis.

CHLORA. Bloss. 8-cleft. Cal. 8 leaves, benealko Caps. 1-celled: 2.valued: many-seeded.. 
VACCINIUM: Cor. monopetala. Cal. quadridentatus, superus. Bacca.

VACCINIUM. Bloss. 8-cleft. Cal. 4-toothed: superiour. Anthers awned in the middle. Fruit a Berry.

IRICA. Cor. monopetala. Cal. tetraphyllus, inferus. Capsula:

ERICA. Bloss. 4-cleft. Cal. 4 leaves; beneath. An_. thers cloven. Caps. many-seeded.

* * Fl. incompleti.

2 Flowers incomplete:

DAPHNE. Cal. corollinus, quadrifidus, inferus: Bacca monosperma.

DAPHNE. Cal. 4-clefi; equal; resembling ablos. som. Stamens inclosed. Berry pulpy.

\section{TRIGYNIA。}

$$
\text { Styli } 3 \text {. }
$$

POLYGONUM. Cal. quinquepartitus, corollinus inferus. Cor. nulla. Sem. linicum, nudum.

POLYGONUM. Cal, with 5 divisions: coloured: Bloss, none. Seed 1. naked. 


\section{TETRAGYNIA.}

$$
\text { Styli } 4 \text {. }
$$

ADOXA. Cal. semiinferus. Cor supera, quadri. vel quinque-fida. Cups. caly ce tecta.

ADOXA. Bloss. superiour; 4 or 5 -cleft. Cal. 2 leazes. Berry with 4 or 5 seed's.

PARIS. Cal tetraphyllus. Pet. quatuor. Becca su. pera.

PARIS: Bloss. 4 petals; awl-shaped; Cal. 4 -leco ved. Berry 4 seccied.

\section{OCTANDRIA.}

\section{MONOGYNIA.}

EPILOBIUM. Smith. 409. With. 366.

Cal. quadrifidus. Pelala quatuor. Capsula ob. longa, infera. Semina papposạ.

Cal. 4-leaved, deciduous. Petals 4. Eaps. beneath, 4.celled, very. long: Seeds many, downy at the top.

hirsu- E. foliis semiamplexicaulibus ovato-banceo. tum. latis hirsutis, caule ramosissimo, radice repente.

E. Leaves egg-spear-shaped, hairy, kalf.embracing the siem: Siem very much branched and huiry. 
GREAT HAIRY WIILOWFHERB. CODLINGS AND CREAM. Noist hellges, ditclies, b nks of brooks, rivers, and lakes; common. Newark; Southrrell.

P. July.

E. folis sessilibus lanceolatis pubescentibus, parviflo. caúle subsimplici villoso, radice fibrosa. rum.

E. Leaves spear-shaped, pubescent, nearly sitting; stem hairy, unbranched.

SMALL-FIOWERED HOARY WILLOW-HERP. WTatery places, and Banks of uitches and rivers; common. Southwell; Newaric.

P. July.

E. foliis petiolatis ovatis dentatis, caule tercti, montio. stigmate quadripartito.

num.

E. Leaves opposite, egg-shaped. toothed; the upper ones allernale: stem cylindrical.

BROAD SIOOTH-LEAVED WILLOW-HERB. In woods, hedge rows, shady lanes, and moist neasdows. On Edingley fIill; Eperstone Park. P. July.

L. foliis lanceolatis, denticulatis, caulc tetra. tetrago gono, stigmate indiviso.

num.

E: Leaves spear-shaped, finely trothed, the lowermost opposite: sten 4-cornered: sum- 1 mit enlire. CURT.

SQUARE-STAIKED WILLOW-HERB. Marshes and sides of rivulets and ditches; freguent. P. July.

E. foliis sessilibus lanceolatis subdenticulatis, paluscaule tereti, stigmate indiviso.

tre.

E. Leaves opposite spear-shaped, ivery entire: petals notched at the end:- ftem upright.

ROUND-STALKED MARSH WILIOW-HERB. Marshes, hogs, and sides of lahes. On Fidingley Noors, uear Farnsficld; Oxton buttous. Sulg. 
CHLORA. Smith. 413. With. 369.

Cal. octophyllus. Cor. octopartita. Stigma quadrifidum. Capsuta supera, unilocularis, bivalvis, polysperma.

Cal. 8-leaved. Bloss 1 petal, 6 or 8 cleft. Caps. 1-celled, 2-valved, many-seeded.

perfoli. C. Soliis perfuliatis.

ata. C. Leaves perforated.

YELLOW CENTAURY In clayey or marly grounds: moumainons meithws and masture.. in a calcareous snil. Southwell: Winkhum; Halum; Kirklington; sides of the hill near Oxten 'Poll-bar. A July, Aug.

VACCINIUM, Smith. 4'4. With. 370 .

Cor. monopetala: Stamina receptaculo inserta. Antherce apice poris duobrrs. Bacca infera, quadrilocularis, polysperma.

Calyx supeaiour.' Bloss. ipejal. Filaments fixed to the receplacle Berry 4 -celled, many-seeded; berreath; dimpled.

* Fuliis deciduis.

1 Leaves annual, or deciduous.

Myrtil. V. pedunculis unifloris, foliis ovatis serratis iz.s. deciduis, caule angulato.

V. Fruit-slalks 1-flowered; leaves serraied, egg.shined; stem angular.

BILIERRY or BIFABERRY. In mnistish wools,

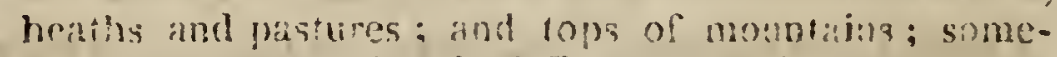

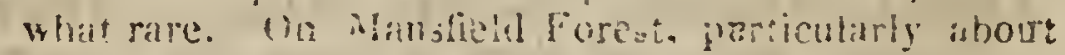
Thompsons árate. 


\section{* Foliis sempervirentibus.}

2 Leaves evergreen.

V. follis ovatis integerrimis revolutis acutis, Oxycoca caulibus repentibus filiformibus glabris. cus.

V. Fruit-stalks single, or in pairs: leaves egg-shaped, very entire, edges rolled back: stem thread-shaped, trailing, not hairy..

CRANBERRY. MOSS-BERRIES. MOOR-EERKIIIS. Peaty bogs, and on Moors; not common. Oxton Bottoms.

P. Juse,

ERICA. Smilh. 417. With. 372.

Cal. tetraphyllus. Cor. quadrifida. Stamina receptaculo inserta: Antherce poris duobus. Capsula supera, quadrilucularis, polysperma. Cal. A-leaved. Bloss. 4 clefted. Filaments fixed to the receptacle. Anthers cloven and perforated at the top. Caps 4 -celled, 4 -valved. many seeded.

* Antheris aristatis.

1 Anthers with a tooth-serrated awns at the base

E. Antheris aristatis inclusis, stylo exserto, vulgaris. corolla quadripartita calyce breviore, foliis oppositis calcaratis.

E. Leaves arrow shaped.

COWUON HEATH, or LING. Heaths and woods; coillinon.

S. June, July.

E. Antheris aristatis, stylo incluso, corolla Tetra. avata. fuliis quaternis ciliatis, floribus ca- lis. pitatis. 
s2: OCTANDRIA. MONOGYNIA. Daphne:

E. Leaves oblong, fringed, cottony uuder. neath: flowers in umbels: cups fringed, and cottony.

CROSS-LEAVED HFATH. Moist heaths; not uncommon. Oxton Bottoms; Coddington Moors.

S. July, August.

* Antheris cristatis.

2 Anthers with 2 toolhed-serrated awns at the base.

cinerea. E. antheris cristatis, siylo subexserto, stigmate capitato, ccrolla ovata, foliis ternis.

E. Leaves spear-shaped, entire, smooth: flow. ers in umbels, egg-shaped: cups finely serrated: branches woolly.

FINE-LEAVED HEATI. Oxton Bottoms ; Stapleford Moor.

s. July, Aus.

DAPHNE. Smith. 420. With. 376 .

Cal. corollinus, quadrifidus, marcescens, stamina includens. Bacca monosperma.

Calyx generally none. Bloss. 1 petal, regular, 4.cleft, funnel-shaped Drupa like a berry, 1-cclled, superiour.

Laureo- D. racemis axillaribus subquinquefloris, fola. liis lanceolatis glabris.

D. Bunches of about 5 flowers, axillary: leaves spear-shaped, smooth.

SPURGF LAUREL. Woods and hedges; not common.

- Lu Kirklington, $W$ inkburn, and Halloughton Woods.

S. March.

ACLR. Smith. 421. With. 368 : 


\section{OCTANDRIA. TRIGYNIA. Polygonum. 123}

Cal. quinquefidus. Petala 5. Cäpsulae 2, vel 3 , super, monospermæ, ala terminatæ.

Calys 5-cleft. Bloss. 5 pelals. Caps. 2 or 3 ; 1-seeded; ending in a leaf-like expansion. Flores aliquot masculi. Male flowers intermixed.

A, fuliis quinqueglobis, inæqualiter serratis, $P_{\text {seudo- }}$ racemis pendulis.

A. Leaves 5-lobed, blunt, unequally serrated; flowers in compound, pendent bunches

GREATER MAPIE. SYCAMORE. Woods, hedges. Southwell; Newark.

T. May, June.

A. foliis lobatis obtusis incisis, racemis erec- campes. tis. platanus.

A. Leaves 5.lobed, very entire: the lower lobes nolched: corymbus with 3 divisions, upright:

COMMON MAPLE. Hedges ard thickèts; common;

S. Mlaj, Juno.

\section{TRIGYNIA.}

POLYGONUM. Smith. 423: With. 379.

Cal. quinquepartitus, coloratus, corolinus, persistens. Semen unicum, superum, angulatum, calyce tectum. Stamina et pistilla numero incerta.

Cal none: Bloss, resembling a cup, with 5 divisions. Seed 1, angular; generally naked. 
124 OCTANDRIA. TRIGYNIA. Polygonum.

* Digyna.

1 Flowers wilh two pistils.

amphibi. P. floribus pentandris semidigynis, spica ova. um.

ta.

P. Siyle cloven: spike egg-shaped.

AMPHIBIOUS PERSICARIA. In cultivater ground, and in ditches. Newark. P. July, August.

Persica = P. floribus hexandris semi-digynis, spicis 73a. ovato-oblongis, erectis, pedunculis lavibus stipulis ciliatis. CuRT.

P. Siyles 2: spikes egg-oblong: leaves spear. shaped: stipula fringed.

SPOTTED ARSMART. Ditches on the side of water, and sometimes in cornfields. Newark. A. July, Aug.

H.dro. P. floribus hexandris semidigynis, foliis lanpiper. ceolatis undulatis immaculatis, spicis fili. formibus nutantibus, caule erecto.

P. Flowers with cloven pistils : stipule some. what fringed: leaves spear-shaped.

BITINR; PERSICARIA. Watery places, on the sides of rivulets, lakes, and ditches; iregue:ni. $A$. Sept,

\section{* * Trigyna.}

2. Flowers wath 3 pistils.

Bistor. R. caule simplicissimo monostachyn, foliis ta. ovatis undulatis in petiolum decurrentibus.

P. Leaves egg-shaped, extended at the base along the juotsialks.

GRFAT BISTORT, or SNAKFETEN. Noist merdows. In'a ('lose becween the Leen and Lenton Churchs yard. DEERING.

P. Jure. 
P. folibus axillaribus, foliis elliptico-lanceo- aviculatis margine scabris, stipularum nervis re- lare. motis, caule procumbente herbaceo.

P. Flowers axillary: leaves spear-shaped: stem trailing.

KVOT-RASS. Road sides, paths, streets, and corn. fields; common.

A. April---Oct.

P. foliis cordato-sagittatis, caule erectiuscu. Fagopy lo inermi, seminum angulis æqualibus. rum.

P. Leives heart-ariou-shaped: stem nearly upright: without prickles: angles of the seeus equal

BUCK-WHF: T. Cornficlds, About Sir Richard suttoin, iemple, on therwood furest; Bl dworth; C umber.

A. July, rugust.

P. foliis curdato.sagittatis, caule volubili an. Convolm gulato, lacinis caly cinis obtuse carinatis. zulus.

P. Leaves hearl shaped: stem twining, angular: flowers blunted.

CLINBIVG. BUCK-WHEAT. BLACK BIVD. WWEED. Cornfields, gardens, and hedges; commori.

A. June, July。

\section{TETRAGYNIA.}

PARIS. Smith. 431. With. 385 .

Cal. tetraphyllus Prtala 4, angustinra. Bac. ca supera, quadrilucularis. Anthere meaiig filamentis adnatie. 


\section{OCTANDRIA. TETRAGYNIA. Aduxa.}

Calyx 4 leaved. Petals 1 , narrower. Berry 4.celled.

quadri. PAR!S.

folza. P. Stem.leaves generally: 4 .

HERB-PARIS. TRUF LOVE. ONF BERRY. TO poods and shady places. Thicke's near (Ixton Tollbar; and in the following Woods; Eperstone, i oundeg, Colwick, Manzer-gorze.

P. May.

ADUXA. Smith. 432. With 386.

Cal. bifidus vel trifidus, semiinterus. Cor. quadri-vel, quinque.fida, supera. Capsula quadrivel quinque locularis, calyce coditca.

Cal. cloven; benealh. Bloss. 4 or 5 cleft; sue perior. Berry 4 celled; uniced to the cup.

Mosrha. ADOXA.

Lelliza. TUBYROUS MOSCHATEIL. Damp woots and shasly plares; not frequent. (1) ton stew; shady Banke in the Marshes at Mansleeld. Basford Scottum. DER.RXnig. P. April, Maj. . 


\section{Classis $I X$.}

\section{ENNEANDRIA,}

Stamina 9 .

\section{HEXAGYNIA.}

Styli 6 .

BUTOMUS. Cal.nullus. Pet. sex. Caps. sex, poly-permæ.

BUT()MUS. Involucr. simple; of 3 leaves. Bloss. 6 petals. Caps. 6. Seeds many.

\section{Ix ENNEANDRIA.}

\section{HEXAGYNIA.}

BUTOMUS. Smith. 436. With 393.

Cal. nullus Pelala 6. Capsula 6. superæ, - polvsperma.

Involucrum simple; of 3 leaves. Pit $t$ ls 6 . Caps. 6 many seeded. Seeds fixed to the sedes of the capsules. 


\section{ENNEANDRIA. HEXAGYNIA. Butomus.}

\section{umbel. BUTOMUS.}

latus.

WATFR CII.ADIOI.F. FLOWFRING RUSTI. SlOW streams and fi whlly ditctes: no' common. Kelham Bridgt; and on the Banks of the T: ent in other places; Banhs of the River Levon, at Markham kridge.

P. Juve, July. 


\section{Classis $X$.}

\section{DECANDRIA.}

Stamina 10.

DIGYNIA.

Styli 2.

SCLERANTHUS: Cor. nulla. Cal. monophyllus. Sem. duo.

SCLERANTHUS. Bloss. none. Calyx 5-clef: superiour. Seeds 2.

CHRYSOSPLENIUM. Cor. nulla. Cal. corolatus. Caps. birostris, polysperma.

CHRYSOSPLENIUM. Bloss. none. Calyx superiour. Caps. 2-celled: 2.berked.

SAXIFRAGA. Pet. quinque. Cal. quinquepartitus. Caps. birostris, polysperma.

SAXIFRAG.A. Bloss. 5 petals. Calyx with 5 dis visinns. Caps. 1-celled; 2.beaked.

SAPONARIA. Ptt. quinque. Cal. monophyllus, basi nudus. Caps. oblonga.

SAPONARIA. Bloss 5 petals. Calyx tubular: naked at the base. Caps. 1-celled; oblong. 


\section{3 zo DECANDRIA. TRIGYNIA.}

DIANTHUS, Pet. quinque. Cal. monophyllus, basi squamusus. Caps. oblonga.

DIANTHUS. Bloss. 5 peials. Calyx tubular; with scales at the base. Caps. 1.celled; oblong.

\section{TRIGYNIA.}

\section{Styli 3 .}

ARENARIA. Caps. unilocularis. Pet. integra, pa. tentia.

ARENARIA. Caps, 1-celled. Petals entire: expanding.

STELLARIA. Caps, uniloc, Pel, bipartita, paten. tia.

STELlARIA. Caps. 1.celled. Petals deeply divided; expanding.

CUCUBALUS. Bacca uniloc. Pet. bifida, unguiculata.

CUCUBALUS. Caps. 3-celled. Petals cloven. Munth naked.

SILENE. Caps semitrilocularis. Pet. bifida, unguiculata. Cal. monophyllus.

SILENE. Caps. 1 to 3 cells. Petals (mosily) clo. ven. Mouth croouned: 


\section{PENTAGYNIA.}

\section{Styli 5 .}

SEDUM. Caps. quinque, squama nectarifera ad basin. Cor. pentapetala.

SEDUM. Caps. 5, adjoining the neclaries. Bloss. 5 peials.

OXALIS. Caps. quinquelocularis, angulata. Sem. bina, arillata. Pet. basi connexa.

OXALIS. Caps. 5.celled; angular. Bloss. petals connected at the base.

LYCHNIS. Caps. quinque vel uni-locularis, polysperma. Cal. tubulosus, membranaceiss.

LYCHNIS. Caps. 1, 3, or 5-celled; oblong. Ca. lyx oblong; membranaceous.

A GROSTEMMA. Caps, uniloculáris. Cal. tubulosus, coriaccious.

AGROSTEMMA. Caps. 1-cell; oblong. Calyx tubular; membranaceous.

CERASTIUM. Caps. unilocularis. Pet. bifida. Cal. pentaphyllus.

Cerastium. Caps. 1.celled. Petals clover. Calyx 5-leaved.

SPERGULA Caps. unilocularis. Pet. integra. Cal. pentaphyllus.

SPERGULA. Caps. 1.celled. Pctals entire. Calyx 5-leaved. 


\title{
133 DECANDRIA. DIGYNIA. Chrysosplenium,
}

\section{× DECANDRIA.}

\author{
1 DIGYNIA.
}

CHRYSOSPLENIUM. Swith. 447. With. 401 .

Cal. quádrifidus seu quinquefidus, coloratus. Cor. nulla. Capsula brostris, unilocularis, semiinferus, semibivalvis, polysperma.

Cal. coloured, 4 or 5 clift. Bloss none. Caps: 2.beaked, i-celled, many seeded, partly beneath; division of the values extending but half-way down.

alterni-C. foliis alternis.

folium. C. Leaves allernate.

ALTERNATI-IEAVED GOIDEN SAXIFRAGF. in wet shady roods, with C. oppositifolium, but less frequent. In a bitch at the bottom of Eperstone Wood. P. Nay;.

oppositi- C. foliis oppositis.

folium. C. Leaves opposite.

OPPOSITE-LEAVED GOHIEN SAXIFRARE. Moist shaty places, sides of burey rioulets and sprinirs. Pond-head, Oxton Botsoms; in a Ditch at the bottom of Eyerstone $\mathbf{W o g l}$, with C. alternifolimu.

P. :prit, May.

SAXIIRAGA. Smith. 448 . With. 402.

Cal. quinquefidus, persistens. Cor. pentapetala. Capsula birostris, unilocularis, polysperma, inter rostra dehiscens. 
Calyx 5-toothed. Bloss. 5 petals. Cips. beneath: 2-beaked, a-celled, many-seeded. opening wath a hole between the styles.

Foliis lobatis.

Leaves lobed: stem upright.

S. Coliis renifomibus lubatic, caule panicula-grantsto, radice grauulat, germine semintero. lata.

S. Stem lenves kidney-shaped, gashed: stem branched: root beaded.

WHAVE SixuFRAGR. Dry meadows and pastures. Southwell; in the Quonce Clote, in Newark; Averhatri Meudows; Ldingley Lill; Kirkliggton.

$$
\text { P. Ap il, May. }
$$

S. foliis cuneiformibus trifidis quinquefidisve tridacty. alternis: summis indivisis, caule panicula- lites. to, germine infero.

S. Stem-leaves wedge-shaped, alternate, 3cleft: stem branched: leaves, in very dry suluations, sometimes windivided.

RUF-LEAVII) SAXIFRA\{XE. On walls, roofs, and aunongst rubhish. Southwell; Newark.

A. April, May.

SCLERANTHUS. Smith. 457. With. $40 \%$ Cal. monophyllus, inferus. Cor. nulla. Se. mina duo, calyce inclirsa.

Cal. 1-leaf. Bloss. none. Seed 1, inclosed in the cup.

S. calycibus fructus patulis acutis, caulibus annuus. patentibus.

S. Calyx, segments thornless: tapering to a point: open when the fruit is ripe. 
134 DECANDRIA. DIGYNIA. Saponaria:

ANNUAL KNAWF.LL. Sandy ground Cornfields and in a nursery of mine betiveen Newark and Banhy; Newark; Farusfield; Blidworth.

A. July.

SAPONARIA. Smith. 459. With. 408.

Cal. monophyllus, nudus. Petala quinque, unguiculata. Capsula supera, oblonga, sub. unilocularis.

Caly $\bar{x}$ \& leaf, naked. Petals 5, with claw's. Caps. cblong, of 1 cell.

offcina-S. calycibus cylindricis, foliis elliptico-lanlis. ceulatis.

S. Calyx cylindrical: leaves egg-spear-shaped.

SOAPWCRT. Meadowa and hedges, but not comnon. In the hedges of a clone aljuiniug tia late that learls from Mansfeld to Sherwod bill. Neas the Nensideld bath. Dfenisg. P. August.

DIANTHUS. Smith. 460 . Wilh. 4 ng.

Cal. cylindricus, monophyllus, basi squama. tus. Pelala 5. unguculata, Capsula cylindrica, sipera, unilocularis.

Cal. c)lindrical. of 1 leaf, with from 2 to 8 scales at the base. Peidis 5, with cluwes. Caps. cylindrical, 1-celled.

delto. D. fluribus solitariis, squamis calycinis ovatoides. lanceolatis acutis subbinis, foliis obrusinsculis, subpubescentibus, peralis crenutis.

I. Scules of the calyix 2: egg-spear-shaped, acule: petuls toothed at the end.

MAIDEN PINK Sandy mendowe, pastures and rocky places. Rocks in Nottingham Park, and athun Gallows Hill; also ia Len'on !hollows near Nortinghan; Sandy Wanks uear fiollerton, by the side of the Derby road.

B. July---October. 


\section{TRIGYNIA.}

SILENE. Sinith. $46_{5}$. With. 413 .

Cal. monophyllus, ventricosus. Pctala 5, unguiculata. Capsula supera, semitrilocularis, apice dehiscens, polysperma.

Calyx distended. Petals 5, with claws: crowned at the mouth. Caps.t or 3-celled.

S. floribus paniculatis secundis cernuis, peta- nutans. lis bipartitis: laciniis linearibus, foliis lanceolat is pubescentibus.

S. Petals cloven : calyx ribbed: flowers lateral, ponting one way, bowed downwards: panicle drooping.

NOTTIVGHAM CATCHFLY. On the walls and rocks of Not:tngham Casile; Rccks at Suenton, a mile from Noltingham. P. June, July.

C. floribus paniculatis cernuis, petalis semi-irflata. bifidis subnudis, calycibus glabı is reticu. lato-venosis, caule erecto.

C. Calyx nearly globular, smooth, with a network of verns: leaves egg-spiar-shaped, glaucous, smooth.

Cucubalus Behen. Linn. With.

BLADDER-CAMPION, or CATCHFIAY. Cornfields and meadow's, in a limestone soil. Bericon Hill, near Newalb; and about the Sto:e-pits. H. June-.-Aug. 


\section{6, DECANDRIA. TRIGYNIA. Stellaria.}

STELLARIA.' Smith. 472 . With. 417 .

Cal. pentaphyllus, patens. Petala 5, bipartita. Capsula supera, unilocularis, poly'sperma, apice sexdentata.

Cal. 5 leaves, expanding. Petals 5, mostly divnded down to the base. Caps. 1 cell. Seeds many.

media. S. foliis ovatis, caulibus procumbentibus li. nea laterali pilcsa alterna.

S. Petals deeply divided: leaves egg-heartshaped: stems with a haily ridge on one side.

Alsine media. LINN.

COMMON CHICKW EED. In gardens and cultivated ground; very common.

A. March, Oct.

holostea. S. foliis lanceolatis serrulatis, petalis bifidis, calyce cnervi.

S. Leaves spear-shaped, very finely serrated: petals cloven.

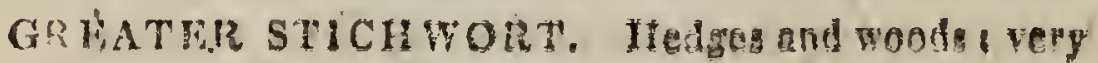
connic n.

i". Anril, May.

grami. S. foliis lineari-lanceolatis integerrimis, paninea. cula terminali divaricata, calyce trinervi petalis subæquali.

S. Leaves strap-shaped, very entire: flowers in panieles.

LESSER STICHWORT. In meadows, pastures, and hed,e bunks; Newark; Southwell. A. May. 


\section{DECANDRIA. TRIGYNIA: Arenaria,}

S. foliis elliptico-lanceolatis integerrimis a- uligipice callusis, floribus subpaniculatis latera- nosa. libus, petalis calyce brevioribus.

S. Leaves spear-shaped, very entire: stems trailing: panicles lateral.

BOG STICH WORT. Sides of springs, rivulets, ditches, and bogfy meadows. Idingley Moors; Farnsfield Carr; Oxton Bottoms; Harshes ahout Southwell and Halam; Cordington and Stapleford Moors.

A. June.

ARENARIA. Smith. 477. With. $4^{21}$.

Cal. pentaphyllus, patens. Pelala 5 s integra. Capsula supera, unilocularis, polysperma:

Cal.5 leaves, expanding. Petals 5, entire. Caps. 1.celled, many seeded.

A. foliis ovatis acutis petiolatis nervosis, ca- trinerlycibus carina scabris obsolete trinervibus. via.

A. Leaves egg-shaped, 3-fibred, pointd, on leaf-stalss.

PLANTAIV-LEAVED CHICKWEED, or SAND. WORT. Woods, banka, and wet heilges. Ilalam Beck; Thurgar!on Water. A. May, June.

A. foliis ovatis subsessilibus scabris, calycibus serpyllihirsutis subquinquenervibus.

A Leaves somewhat egg-shaped, acute, sitting: blossoms shorter than the calyx.

THYME-LFAVID SANDWORT. On roofs, walls, sandy and very dry places. Southwell; Newark.

A. June, July.

A. foliis linearibus mucronulatis, stipulis sca- rubra. riosis vaginantibus, seminibus compressis angulatis scabriusculis. 
A. Leaves thread-shaped, opposite, but half the length of the joints of the stem: stem prostrate: calyx as long as the capsule.

PURPLE SANDWORT. Sandy lancs, meadows, and road sides. Gravel-walks at Southwell; Sherwood Forest; Mansfield; Coddington Moors.

A. July, August.

\section{PENTAGYNIA.}

SEDUM. Smisth. 485 . With. 426 .

Cal. quinquefidus. Cor. pentapetala. Squama nectarifera 5 , ad basin germinis. Capsula 5 , superæ.

Cal. 5-cleft. Bloss. none, or 5 petals. Nectariferous Scales 5 , at the base of the germens. Caps. 5, disinct, like a legumen.

\section{Teretifolia.}

Leaves roundish, nearly cylindrical.

dasyphyl. S. foliis oppositis ovatis obtusis carnosis, lum. caule infirmo, panicula glutinosa.

S. Leaves opposite, egg-shaped, blunt, fleshy; stem weak; flowers scattered.

THICK-LF, V B,D STONE-CROP Walls and rocks; rare On Walls near Kirkby Church. P. June.

acre. S. foliis alternis subovatis carnosis gibbis adnato-sessilibus, cyma trifida foliusa.

S. Leaves nearly egg.shaped, grouing to and satting, bulging, nearly upright, alternate: tuft with 3 divisions. 
DECANDRIA. PENTAGYNIA. Oxalis. 139

STOVT-CROR. WAIT, PYPPRR. On whlls, roofs, rocks, dry banke, ant pustures. Jarks ol he Hedges of the Close next Finler's Bririge, in the Foot-road from Newark to Kelham; Qmonce Cluse, at Newark.

P. June.

S. foliis subulatis sparsis hasi solutis : inferi- reflexoribus recurvatis, floribus subcymosis. um.

S. Leavis aul-shaped, scattered, loose at the base; the lower ones bowed hith.

YELLOW STONE-CROI'. On wails. roofs, ant roses. On the Wall of the Palice at Southuell. P. Iuly.

OXALIS. Smith, 491 Wish. 429.

Cal. pentaphyllus. Betala 5, unguibus connexa Capsula supera, quisquelocularis, angulis dehiscens, pentagona. Semina arillo elastico tectia.

Calyx 5 leaves. Petals connected by the claws. Capsules 5-sided, opening at the corners.

O. scapo unifloro, foliis ternatis obcordatis Acetopilosis, radice squamoso-articulata. sella.

O. Stalk with 1 flower: leaves 3 together: leafits inversely heart-shaped, hairy.

COMMON WOOD SORREL. in woods and shady places. Westhorpe Dumal, near Southwell; Thickets near Oxton Toll-bar; Eperstone, Colwick, A sply, and Broxtow Woods. $\quad$ P. April, Niay.

AGROSTEMMA. Smith. 493. With. 431: Cal. monophyllus, coriaceus. Petala 5, unguiculata ; limbo obtuso indiviso. Capsula supera, unilolocularis, ore quinque-dentata.

Calyx 1-leaf, like leather. Petals 5 , with claws; border blunt, undivided. Caps. x-celled. 


\section{DECANDRIA. PENTAGYNIA. Lychnis.}

Githago. A hirsuta, calyce corollam superante, petalis integris nudis.

A. Plant hairy: calyx as long as (or longer) than the blossom, petals entire, not crowned. CORN COCKLE. In cornfields; freqnent. Newark; Southwell. A. June, July.

LYCHNIS. Smath. 493. With. 431.

Cal. monophyllus, oblongus. Petala quinque, unguiculata, limbo sæpius diviso. Capusla supera, ore quinquedentata, 1 5 locularis.

Calyx 1 leaf, oblong, even. Petals 5, with claws, limbs ofien cloven. Caps. 1 to 5 celled.

Flos- L. petalis quadrifidis, fructu subrotundo uniCuculi. Joculari.

L. Petals ( 3 or) 4 .cleft: fruit roundish : of 1 cell.

RAGRED-ROBIN. MEADOW LYCIIYIS. MOist meadows and pastures; very common. P. June.

dioica. L. floribus dioicis, fructu uniloculari.

L. Stamens and pisitls in disiznct plants: capsules 1 -celled.

RED CAMPION. Hedges, ditches, and moist woods; very frequitunt.

P. Nay--.iept.

CERASTIUM. Smith. 496. With. 433 . Cal. pentaphyllus. Petala bifida. Capsula su. pera, apice dehiscens, ore deccmdentata, unilocularis.

Calyx 5-leaved. Petals cloven. Caps, 1-celled, opening at the top. 
C hirsutum viscidum cæspitosum, foliis o- vulgavatis, petalis calyci æqualibus, fluribus pe- tum. dunculo longioritus.

C. Leaves egg-shaped: petals as long as the calyx: stems spreading.

BROAD LEAVED MOUSE IAAR. CHICKWEED. Me dows. pastures, on walls, sides of roads, cardens; Southwell; s lewark.

A. A pil, May.

C. hirsutum viscidum diffusum, foliis lanceo- viscolato.oblongis.

C. Upright, woolly and clammy.

NARROW-LEAVED MOUSE-FAR CHICKWERD. Meadows, pastures, and ant.hil!s; not uncommon.

P. May, ent.

C. foliis lineari-lanceolat is obtusis basi cilia-arvense. tis, petolis calyce duplu longioribus.

C. Leazes strap-spear-shaped, bluntish, fringed at the base: blossoms larger than the cabyx.

FIELD CH TCKWIED. Cornfelds, gravelly meadows,

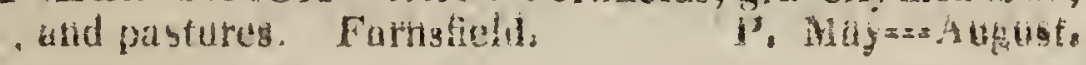

C. foliis cordatis sessilibus, peduneuli latera. aguelibus olitaris: fructiferis reflexis, capsula tzemsovata ore quinquedentato.

C. Leaves heart-shaped, silting : fluwers solitary: capsules pendent.

WATER-CHICKWRD. Watery Haces mus of rivers. mostly amonest busives. Ditch banks near.

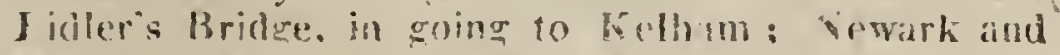
Averham Meadows; A acham lane; dingley.

$$
\text { P. July. }
$$

SPERGULA. Smith: 502. With. 436 . 
$14^{2}$ DECANDRIA. PENTAGYNIA. Spergula.

Cal. pentaphyllus. Petela 5, integra. Capsula supera, ovato, unilocularis, quinquevalvis.

Cal. 5 leaves. Petals 5 , extire. Caps. eggshaped, of 1 cell and 5 values.

arven- S. follis verticillatis, pedunculis fructiferis sis. reflexis, seminibus reniformibus.

S. Leaves in wharls: flowers with more than 5 stamens: stems thick at the joints.

CORN SPURRT. Corb-fie'ds and sandy places, especially where whice has lain and gravel walks ficegitent. In tields and roods about $N$ ewarks.

A. July-..-Septeatber.

pentan. S. foliis verticillatis, foribus pentandris, se. dra. minibus depressis alatis.

S. Leaves in whirls; flowers with 5 stamens; seeds depressed, winged:

LITTLE CORN SPURRY. Sandy places. Famsfield. A. June.

modosa. S. foliis oppositis subulatis lavibus: superioribus fasciculatis, calyce enervi.

S. Leaves opposite, awl-shaped, smooth; stem. simple.

KNOTTED SPURRY. Marshy places, wet pastures and sides of rivers, lakes and marshes. On Edingley Moors ; Earnstiel! Carr; Oxton Bottons.

l. July, August. 
Classis XI.

\section{DODECANDRIA.}

Stamina $12-20$.

MONOGYNIA。

Stylus 1.

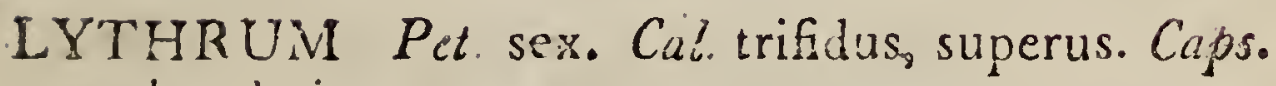
sexlocularis.

LYTHRUM. Bloss. 6 petals. Cal, 12-toothed, beneath. Caps. 1 or 2 celled.

\section{DIGYNIA.}

Styli 2.

AGRIMONIA. Pet. quinque, calyci inserta. Sem. in fundo calycis.

AGRIMONiA. Bloss. 5 petals. Cal. 5-cleft. Seeds 1 or 2. 


\section{$\$ 44$ DODECANDRIA. TRIGYNIA.}

\section{TRIGYNIA. \\ Styli 3 .}

RESEDA. Pet. multifila Caps, unilocularis, hians. RESEDA. Bloss. petals mary-cleft. Cal. divided. Cips. 1-celled, gaping open.

EUPHORBIA. Nectaria pelata. Caps. tricocca. pedicellata.

EUPHORBIA. Bloss. petals fixed by the centre. Cal. bellying. Caps. 3 united áry berries.

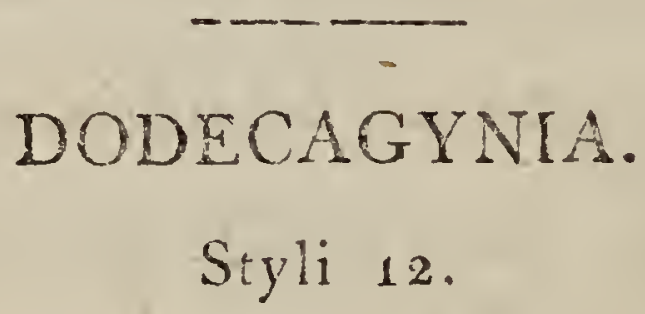

SEMPERVIVUM. Pet. duodecim. Cal. duodecimpartitus. Caps. duodecim.

SEMPERVIVUM. Bloss. 12 peials. Cal, with 12 divisions. Capsules 12.

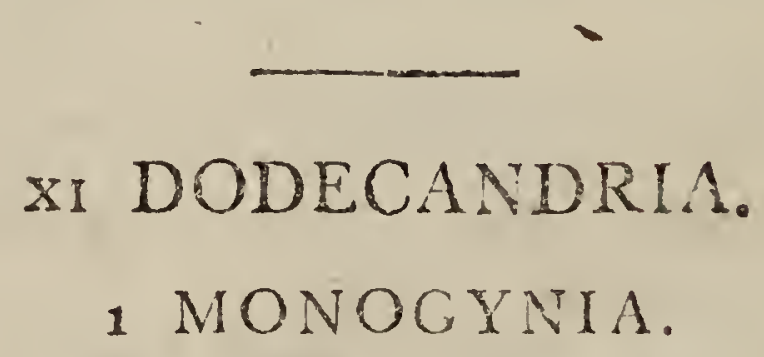

LYTHRUM. Smith. 509 Whit. 441.

Cal. duodecimfid:s, inferus. Pelula sex, calyci inscita. Capsula bilucularis, pulysperma. 


\section{DODECANDRIA. DIGYNIA. Agrimonia: 148}

Cal. often with 12 or 16 tceth. Petals 5 or 6 , fixed to the calyx. Capsule 1 or 2 -celled, many seeded.

L. foliis oppositis cordato-lanceolatis, flori-Salicabus spicatis dodecandris. ria.

L. Leaves opposice or alternale, heart-spearshaped: flowers in spikes, 10 or 12 sta. mens in each.

PUfP PLE WOSESTIRE. Marshes and ranks of rivers. On the Ganks of the River Trent; Ditches about Eouthwell; Newark; Ldingley Moors.

P. July, A uzust.

L. foliis alternis lineari-lanceolatis, floribus hyssopiaxillaribus solitariis hexandris.

L. Leaves allernate: flowers with 6 stamens.

IIYGSOP LEAVHD LOOSESTRIFE, or GRASS. 1) LY. Wiatery plices, and where water has stood during the winer ; rare. In water where water stagnutes helow ivilford boat. DeERING. I have unsucausfully cuderivoured tu find this plant. A. August.

folzum:

\section{DIGYNIA.}

AGRIMONiA. Smith. 511. With. 44\%. Cal. quinquedentatus, calyculdeus. Petala quinque, calyci inscrta. Semina duo, in fundu calycis.

Calyx 5-toothed, surrounded by another. Petal's 5. Sceds 2 , in a capsule at the bottom of the calyx, which becones indurated.

$\mathrm{O}$ 
${ }_{14}^{6}$ DODECANDRIA. TRIGYNIA. Reseda.

Eupato-A. foliis caulinis pinnatis: impari petiolato, ria. fructibus hispidis.

A. Stem-leaves winged: the odd leafit on a leafstalk: fruzt hrsped.

COMMON AGRIMONY. Borders of cornfe!ds. shaty - places, and hedges. Iletige banks, and in lanes about Newark; in Mr. Pochlingion's plan ation facing the Winthorpe lioad, uear the lolly; Parks at Sounhvell.

P. June, July.

\section{TRIGYNIA.}

RESEDA. Smith. 512. With. 445 .

Cal. monuphyllus, partitus. Petala laciniata. Capsula sipera,. apice hians, unilocularis, polysperma.

Calyx 1 leaf, divided. Petals jasged. Capsule 1-celled, many-secded, opening at the top.

Luteola. R. foliis lanceolatis integris planis, calyce quadrifido.

R. Leaves spear-shaprd, entire. with a tooth on each side of the base: calyx 4 -cleft.

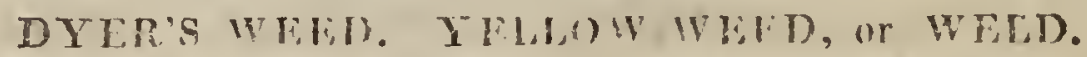
Merdows, pastures. walls, and birren uncul ivated spots; not unommon. In the lane leating to Aicrham Meadur, from the libll, bejond the Cotton Mill at vevari : the road. between Markhall bridue and farndon from Newark. A. July.

lutea. $\bar{R}$. fuliis onnihus trifidis; inferioribus pin. natis, calyce sexfido. 
DDDECANDRIA TRIGYNIA. Euphorbia, 147

R. All the leaves 3. cleft; the lower winged.

WIID HICHOYHTTE or BASE ROCKHT Cornfickls, mealows, pastures, in a calcareous soil; not frenacat. Bulirall Linckilus. A. or P. July, Aug.

EUPHORBIA. Smth. 513. Wilh $44^{6}$.

Cal. monophyllus, ventricosus, inferus. Nectaria 4, rel 5, calyci insidentia. Capsula pedicellata, tricocca.

Calyx y leaf, distended. Bloss. 4 or 5 petals, sutting on line calyx. Caps. 3, united.

* Uinbella trifida.

1 Unkels with 3 spokes.

E. Umbella trifida: dichotoma, involucellis Peplus. ovatis, foliis integerrimis obovatis petiolatis.

E. Umbels with 3 spokes; spokes forked: involucellums ego-shaped: leaves very entire, inversely egg shaped, on leaf-slalks.

PuTTY SPURGE. Rich culivated soil : very frequent. $\quad$ A. July, August.

E. umbella trifida: dichotoma, involucellis exigut. lanceolatis, foliis linearibus.

E. Umbel's with 3 spokes; spokes forked: involucellums spear-shaped: leaves strapshaped.

D W A R F SURGM. Confields; frequent. Beaconfielis, Newark; Coddington; Southwell ; Farnsfield.

A. July。

* Umbella quinquefida.

2 Umbels with 5 spokes.

02 


\section{DODECAN. DODECAGYN. Sempervivum:}

helios- E. umbella quinquefida; trifida: dichotoma, copia. involucellis obovatis, foliis cuneiformibus serratis.

E. Umbel with 5 spokes; spokes with 3 divisions, and these forked: involucellums inversely egg-shaped: leaves wedge-shaped, serrated.

SUN-SPURGE or WART-WORT. In cultivated places, as gardeas and comitids ; frequent.

A. July, Aurust.

\section{DODECAGYNIA.}

SEMPERVIVUM. Smith. 522. With. 452.

Cal. inferus, duodecim-partitus. Petala 12. Capsule 12.

Calyx 12-cleft. Petals 1, 6, 12, to 24. Caps. 12, many-seeded, like a legumen.

teciorum. S. foliis ciliatis, propaginibus patentibus.

S. Leaves fringed: off-sets expanding.

COMMON HOUSBLERK. Roofs of old thatched brildiags. Upten, and some House-tops in Sotilhvell; ou leat-inouses, in Newark. tr. july. 


\title{
ICOSANDRIA:
}

\section{Classis XII. ICOSANDRIA.}

Stamina plura, calyci inserta.

\section{MONOGYNIA.}

\author{
Stylus 1.
}

PRUNUS. Cal. inferus, quinquefidus. Pet. quinque. Lrupa nucleo integro.

PRUNUS. Cal. beneath, 5.cleft. Bloss. 5 petals. Drupa with an entire nut.

\section{PENTAGYNIA.}

$$
\text { Styli } 2 \text { ad } 5 \text {. }
$$

MESPILUS. Cal. superus, quinquefidus: Pet. quinque. Drupa nucibus 2 ad 5 , dispermis. MESPILUS. Cal. superiour, 5-clefi. Bloss. 5.petals Berry with 5 seed's.

PYRUS. Cal. superus, quinquefidus. Pet. quinque. Pomum loculamentis 2 ad 5 , dispermis.

$$
\text { o. } 3
$$




\section{$\$ 50$ ICOSANDRIA. POIYGYNIÁ.}

PYRUS. Cal. superiour, 5.cleft. Bloss. 5 petals. Fruit a Pomum, with 5 cells and many seeds. SPIR EA. Cal. inferus, quinquefidus. Pet. quinque. Caps. bivalves, polysperma.

SPIRÆA. Cal. beneath, 5-cleft. Bloss. 5 petals. Capsules many, crowded together.

\section{POLYGYNIA.}

Styoli plures.

ROSA. Cal. quinquefidus, urceolatus, demum baccatus, polyspermus.

ROSA. Cal. 5-cleft. Bloss. 5-petals. Cup like a berry, with many seeds.

RUBUS. Cal. quinquefidus, Bacca supera, composita, acinis monospermis.

RUBUS. Cal. 5-clefi. Bloss. 5 petals. Berry compound.

TORMENTILLA. Cal. cctofidus. Pet. quatuor. Sem. nuda, mutica.

TORMENTILLA. Cal. 8-cleft. Bloss. 4 petals. Seeds 8, awnless.

FRAGARIA. Cal. deccmfidus. Sem. nuda, lavia, receptaculo deciduo, baccato, affixa.

FRAGARIA. Cal 10-cleft. Bloss. 5 petals. Seeds many, deciduous, situated upon a receptacle resembling a berry. 
ICOSANDRIA. MONOGYNIA. Prunt3. i5n

POTENTILLA. Cal. deceminds. Sem, nuda, rugosa, mutica.

POTENTILLA. Cal. 10-ceft. Bloss, 5 petals. Sceds many, aiunless.

GEUM. Cal. decemfius, Sem. arisa geniculata. liecept. colminare.

GEUM. Cal. 10-oleft. Bloss. 5 peluts. Seeds many, with a knce jounted awn.

COMARUM. Cal decemfilus. Sem nuda, lavia, receptaculo ovato, spongioso, villoso, persistenti, affixa.

COMARUM. Cal. 10-cleft. Bloss. 5 peials. Seeds many, permanent, upon a fleshy receptacle.

\section{ICOSANDRIA.}

\section{MONOGYNIA.}

PRUNUS. Smith. 526. With. 455.

Cal. quinquefidus, inferus. Petala 5. Drupa nux suturis prominulis.

Calyx 5 cleft, beueath. Petals 5. Drupa 1celled, closed at the top. Nut with projecting seams:

P. floribus racenosis; racemis pendulis, foli- Padus. is deciduis basi subtus biglandulosis.

P. Flowers in bunches; leaves deciduous, with 2 glands at the base on the under side.

BIRD-CHERRY. Woods and hedges. Norwood Park.

S. May. 
$15^{2}$ ICOSANDRIA. PENTAGYNIA. Mespilus.

Cera- P. umbellis subsessilibus, foliis ovato-lancrosus. lat is conduplicatis.

F. Uinbels mostly on short fruit-stalks: leaves egg-spear-shaped, smooin, doubled together.

CHCR Y Y TREE. Woods and herges. Halam T. May.

insiti. P. pedunculis geminis, foliis lanceolato-ovatis tia. convolutis subtus villosis, ramis spinescentibus.

P. Fruit-stalks in pritrs; laves egg-shaped, shightly woolly, coiled; branches with thorns.

BULLACE-TREE. fledges. Normanton. T. April.

spinosa. P. pedunculis solitariis, foliis lanccolatis glabris, ramis spinosis.

P. Fruit-stalk solitary: leaves spear-shaped, smooth, branches thorny.

- BLACK THORN, SLOE TREE. Iledges; common. S. March, April.

\section{PENIAGYNA.}

\section{Styli 2 ad 5 .}

MESPILUS. Smith. 529. With. 459.

Cal. quinquefidus. Petala 5. Drupa infera. Nuces 2 ad 5 , disperma.

Cal. 5-cleft. Petals 5. Berry beneath, opening at the top, 1-celled, 1 or more seeded.

Oxya- M. spinosa, foliis obtusis subtrifidis scratis cantha. glabris, floribus subdiginis. 
ICOSANDRIA. POLYGYNIA. Pyrus. 15:

M Leaves mosily 3-cleft: segments blunt ser. rated.

Cratagus Oxyacantha. With. 159.

HAW-THORN. WHITE-TIORN. MAX. IIEIges: very comtinon.

PYRUS. Smith. 531. With. 46 s.

Cal. quinquefidus. Petala 5. Pomum inferum, 2 ad 5 -loculare. Semma bina.

Cal. 5-cleft. Petals 5. Pomum beneath, 5-cello ed, many-seeded.

P. foliis simplicibus serratis, pedunculis commucorymbosis. Hid.

P. Leaves setrated, sinooll : flutiers forming a carymbus.

praR TREe, IRON PEAR TRES. Wonils and hedges.

T. April, viay.

P. foliis simplicibus serratis, umbellis sim-Malus. plicibus sessilibus.

P: Leaves serrated: flowers in umbels, sitting.

APPLE-TREE. CRAB-TREE. Woods and hedges; frequent.

T. May.

P. foliis pinnatis: foliolis xqualibus serratis aucupco glabriusculis, floribus corymbosis subtrigy - ria. nis.

P. Leaves zuinged, smooth on both sides.

Sorbus aucuparia. Linn. With.

MOUNTAIN ASIT. QUICKEN-TRER. WOOLS and hedges, iu mountaino.ss situationj. Eidiugley Hillo T. Ai:ay,

SPIRAA.' Sinith. 535. W2th, $463 \cdot$ 
754 ICOSANDRIA. POLYGiNia. Rosa.

Cal. quinquefidus. Petala 5. Capsula supera, bivalves, polysperma.

Cal. 5.cleft. Petals 5. Caps. 4 or more, 2-celled, 2-valied, many-seeded.

Filipen. S. foliis interrupte pinnatis : foliolis unifor. dula. mibus serratis giabris, caule herbaceo, floribus cymosis polygynis.

S. Leaves interruptedly uinged: leafits strapspear-shaped, irregularly serrated, very sinooth: flowers in ! uftis.

COMMON DROPwCrt. Newtows and pastures, ia

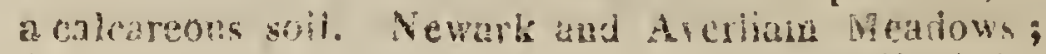

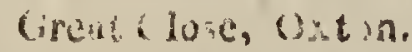

p. July.

Ulma- S. foliis interrupte pinnatis subtus tomentosis, na. impari majori lobato, floribus cynosis polygynis.

S. Leaves interruptedly winged: leafits egroshaped, doubly serrated, hoary underneath: flowers in tufts.

VTA DOW.SWEET. Noist meadow and hanks of ririvers. Ne rark and Averhan Headows; Givet ileat duws, Southwell.

P. June, July.

\section{POLYGYNIA.}

ROSA. Smith. 537. With. 464 .

Eal. urceolatus, quinquefidus; carnosus, col. lo coarctatus. Petala 5. Semina plurima, hispida, calycis lateri inceriori alfixa. 
ICOSANDRIA 'POLYGYNIA. Rosa. 155

Petals 5. Callorn shaped, 5 clmfl, fieshy, contracted at the nech, so as to jormat length a coluured Bury of i cell, openeng at the top. Seeds miny, hispid, dispersed in the pulp.

* Frucibus subglibosis.

- Germens more or liss globuiar.

R. fructibus globosis pcdunculisque glabris, spinosiso aculeis caumis numerosissimus rectis seta- sima. ceis, foliulis subucuidis glabris.

R. Germens and fruil-stalks smooth: stem and lenf: stalks fully set zinth stranght pizckles: leafits circular smooth.

BURNVT ROSE lleiges, beaths, and santy places. Newark; Southwell. S. Ju!y.

$R$. fruclibus glubosis pedunculisque inemi- arvensis. bus, aculeis cantuns petoluruinque aduncis, floribus subcriuess

R. Germens and fruit-stalks smooth: "siem and leaf stulks prukly: flowers zil tiffis.

WHITE nor ROsl: lledges and heathn; common. South" l; ewirk. S. July.

R. Ciructibus globosis pelunculisque hisnidıs, villosa. aculeis cambinis recriusculis, foriuls ellipticis utrinque comentosis

R. Grmans and fruit-stal's hispod: 'stem woin scattered prockles: leaf. siwitis prickily: lecuues coltony.

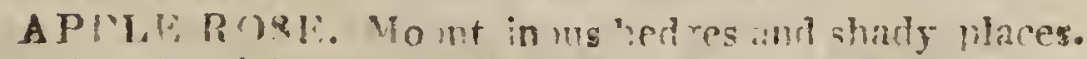

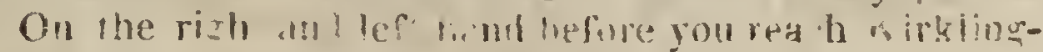
tou Tumpibe-roud, in o oing from Normatiton; on ibe 


\section{${ }_{56}^{6}$ ICOSANDRIA. POLYGYNIA. Rubus.}

high cross hill, in the road from Southwcll to Thurgavon; vear the Pridge across Halam liech, in the road from touthucll io Kirklington.

s. June.

$\because *$ Fructibus ovatis.

2. Germans egg shnped.

rubigi- R. fructibus ovatis perunculisque hispidis, anosa. cules callinis aduncis. fololis ellipticis sub. tus granduloso rubiginosis.

R. Germens and fruit-stalts priclily at the base: prirkles on the stem bint back: leaves rusied unierneath.

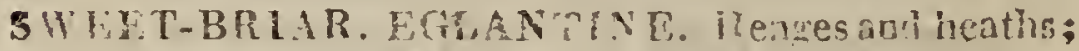

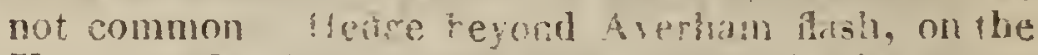
Upton road; also on wate rendub bithe 5 mile-stone, befo:c you arrwe at lotlers" hill, on the fin:nin roav from Newark.

S Juic, July.

-anina. R. frucibus ovatis pedunculisque glabris, aculeis canlinis aduncis, foliolis ovatis acum:natis glaherrimis.

R. Germéns and fruit-stalks imooth: stem and leaf-stalks prichly.

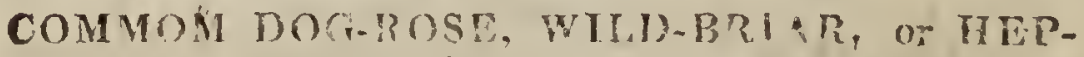
TREL. Helges and woods. Southwell; Nervark.

S. Sune.

RUBUS. Smith. 541. With. 468.

Cal. quinquefidus. Pelaíu 5. Bacca supera, composila acinis monospernis.

Cal. 5-cleft. Petals 5. Styles from the tor of the germens. Drupa clusiered, i-celled, fixed to a conical receplacle, so as to resemble is berry. 
R. foliis quinato-pinnatis ternatisque subtus idaus. tomentosis, petiolis canaliculatis, caule aculeato.

R. Leaves winged, with 5 or 3 leafuts: stem prickly: leaf-stalk channelled.

RASP-BERRY. Waods and herges. Plantation of R. Pocklington, Esq. between Newurk and Barnby.

s May, Jure.

R. foliis ternatis subtus pilosis: lateralibus casius. bihbis, caule aculeato prostrato glauco.

R. Leaves 3 logether, almost bare; lateral leaves 2-lobed: slem prickly, cylindrical: panicle few.flowered.

DEW-BERRY. Woods and bedges. S. June, July.

R. foliis subquinatis subtus pilosis: laterali- coryizbus sessilibus, aculeis rectiusculis, calyci- folius. bus fructus inflexis.

R. Leaves zinged with 3 or 5 leafils, hairy undeineath: luteral leaves satting; prickles siraight, calyxes of the fruit bent inwards.

H (ZLE-LI: QVEI) BRAMBLE. In woods and hedges; not unirequent.

S. July.

R. foliis subquinatis subtus tomentosis: fo- from at liolis petiolatis, aculeis aduncis, caule an-cosass. gulato, calyce reflexo.

R. Leaves winged, with 3 or 5 leafits: siem and leaf-stalks prickly: panicle oblong.

COMMON BRAMBLE. Heilges and woods; common. S. J une---septo

FRAGARIA. Smih. 546. With. 47 . 
45 ICOSANDRIA. POLYGYNiA. Potentilla.

Cal. decemfidus, inferms. Petala 5. Recep. taculum seminum ovatum, baccatum, deciduum, Semina lævia.

Calyx 10.cleft. Petals 5. Seeds naked, smooths on a receptacle, which is egg shaped, colour. ed, deciauous, resembling a berry.

zesca. F. flagellis reptantibus.

F. Leaves 3 together: runners cresping.

WOOD SIRAWBIRRY. Wordiand shady plices: frequent: Eperstone Woorls; Hislar aut Euincley Hills.

P. May, June.

sterilis. F. caule decumbente, ramis floriferis laxis subbiflos is.

F. Stem prostrate, without creeping runners.

BARREY STR LWBERRY. Barren pasture, heatha, and hedge banks. Sherwood leorest P. Miste.', Mr.

POTENTILLA. Smith. 547. With. 472. Cal. decemfidus, inferus. Petala 5. Semina subrutunda, nuda, sæpius rugosd, receptacu10 parro, exsucco, affixa.

Calsx 10-cleft. Petals 5. Seeds roundish. naked. wrinkled, fixed to a Receptacle, which is small, juiceless, spongy, lubercled.

* Fuliis pinnatis.

1 Leaves winged.

anseri- $P$. foliis interrupte pinnatis serrat is suhtus sena. riceis, caule repente, pedunculis unifluris.

$P$-Learies zuinged. serrated: stem creeping: fruz stalks wizlh iflower.

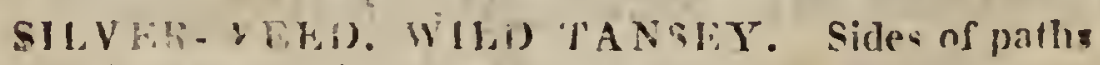
ant roals, and in low pastures, especially where water t.is stoud durıng the winter; commun. 1'. June, July. 
ICOSANDRIA: POLYGYNIA. Turmentilla. 155

$$
\text { * Fuliis digitatis. }
$$

2 Leazies wh the finger like divisions.

to. foliis quindis choeiformibus incisis sub argene tus iomerilusis, caule erectu. tea.

P. Leafits 5 togeiner, wedge-shapod, sript, cotivily linder neatin: siem upright.

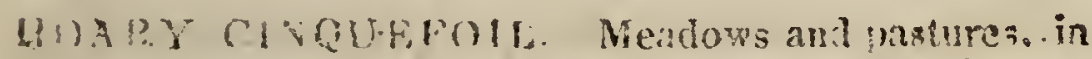
a İH : lo

$$
\text { 12. June. }
$$

P Ellis quinatis obovatis seratis, caule regtons. reprate, pedunculis unifuris.

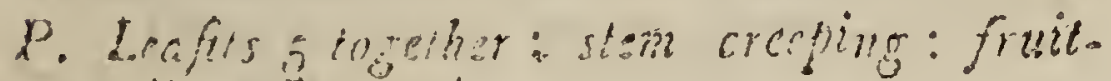
shablis a fiow tied.

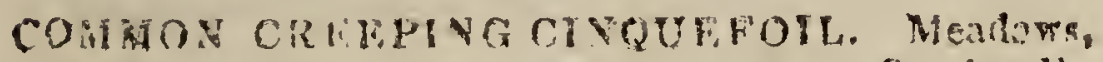
pastures, and roudi-sides; very comnon. Soutine Newark. P. jinj....August.

TORMENTILLA. Sinith. 55\%, Wuth. 476 . Cal. occotidus, inferns. Petala 4. Semina subrotunda, nuda, rugosa, Receptuculo par. vo, exsucco, afixa.

Cal. 8-cleft. Petals 4. Seeds roundish, nao. ked, fixed to a small juiceless receptacle.

$T$. caule erectiusculo ramoso, foliis sessili- offirinabus.

T. Slem somewhat ascending: liaves sitting. T. crecta. LINN.

COMMON TORMENTIL, or SEPTFOIL. MoOrs, barleil pastures, and shady places; conmon. South. riell; terara. P. June. 


\section{5o ICOSANDRIA. POLYGYNIA. Geum.}

repians. T. caule prostrato simplici, foliis pefiolatis.

T. Stem trailing; leaves on leaf-stalk's.

TRAILING TORMENTIL. Wools and barren pastures; rare. On a common pasture in the pirish of Gakring, cillea Manzers Gorze. "P.June, July.

GEUM. Smith. 554. With. 477 .

Cal. decemfidus, inferus. Petala 5. Seminum arista geniculata. Recepiaculun columnare.

Cal. 10 cleft. Petals 5. Styles terminaling. Seed with a jointed awn. Recept. prllar. like.

urba- G. folis ternatis, stipulis rotundatis incisis, rum. flombus erectis, arist is uncinatis nudis.

G. flowers upright: fruit glubulnr, woolly: awns hoohed. base: root-leaves l.jre-shaped: stem-leaves in threcs.

COMVOY AYEYG. MERT PEYNET. WOATS and hedres; connon. Sonhwell; Neurikg.

P. Nivy--.-August.

revale. G. folin radicalibus ly ratis, stipulis ovatis acutis incisis, floribus nutantibus, anstis plumosis tortis.

G. Flowers nodding : fruit oblong : azuns foathered, tuisied: petals blunt, roundas aledge-shaped: leaves winged.

W ATER-AVENS. Wet woods and shady noist places.

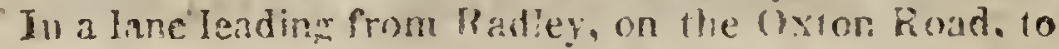

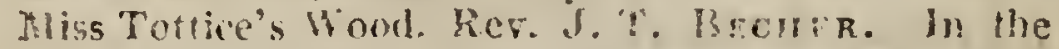
close by Asply liouse, and along the nood sire. 1) ELRINIG. 1. Intic, \&uly.

COMARUM. Smith. 556. Whth. 579. 


\section{ICOSANDRIA. POLYGYNIA. Ceum, 168}

Cal. decemfidus, inferus. Pelala 5, calyce minora. Receplaculum seminum ovatum, spongiusum, villosum, persistens. Semina levia.

Cal. 10.cleft, permanent: segments alternately smaller. Petals 5. Seeds naked, smooth. Recept. globular; fleshy, zooolly, permanent.

COMARUM.

C. Leaves winged: petals smaller than the calyx.

MARSH CINQUEFOIL. Muddy putrid marshes; boǧs. Ponds at Oxton,

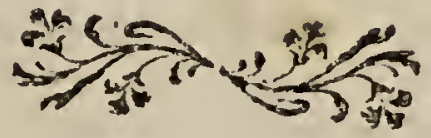

4

P 8 


\section{Classis XII. POLYANDRIA.}

Stamina plura, receptaculo inserta.

\section{MONOGYNIA.}

$$
\text { Stylus } 1 .
$$

* Tetrapetali.

1. Petals 4.

PAPAVER. Cal. diphyllus. Caps. unilocularis, poris sub stigmate dehiscens. PAPAVER. Calyx 2-leaved. Capsule 1-celled; crowned.

CHELIDONIUM. Cal. diphyllus. Siliqua unilocularis. Sem. cristata.

CHELIDONIUM: Calyx 2-leaved. S, vess, a long Pod.

$$
\begin{aligned}
& \text { * Pentapetali. } \\
& 2 \text { Petals } 5 \text {. }
\end{aligned}
$$

CISTUS. Caps. trivalvis, apice dehiscens. Calo pentaphyllus; foliolis duobus minoribus.

CISTUS. Caps. nearly globular. Cal. 5-leaved; 2 leafits smaller.

TILIA. Caps. quinquevalvis, basi dehiscens, coriacea. Cal. quinquepartitus, deciduus. 
POLYANDRIA. PENTAGYNIA, 163

TILIA. Caps. 5-celled; like leaiher. Seed 1. Cal. decrduous.

$$
\begin{aligned}
& \text { * * Polypetali. } \\
& 3 \text { Pelals many. }
\end{aligned}
$$

NYMPHAA: Bucca nuthilocularis, corticosa. Cal. petalis major.

NYMPH无A. Berry many-selled: outer coat like bark. Cal. large.

\section{PENTAGYNIA。}

$$
\text { Styli } 5 \text {. }
$$

AQUILEGIA. Cal. nullus. Pet. quinque. Nect. quinque, inferne cornuta.

AQUILEGIA. Cal. none. Bloss. 5 petals. Nectaries 5: horned in the lower part.

\section{HEXAGYNIA.}

$$
\text { Styli } 6 .
$$

STRATIOTES. Spatha dyphylla. Perianthium - superum, trifidum. Ptt ria. Bacca sexlocularis. STRATIOTES. Cal. with 3 divisions. Bloss. 3 petals. Berry 6.celled; in a sheath. 
$20_{\frac{1}{2}}$ POLYANDRIA. POLYGYNIA.

\section{POLYGYNIA. \\ Siyli plures.}

THAlictruM. Cal. nullus. Pet. 4-5. Sem ecaudata.

THALICTRUM, Cal. none. Bloss. 4 or 5 petals. Seeds many; awnless: naked.

Clematis. Cal. nuilus. Pet. 4-6. Sem. cau. - data. liecept. capitatum.

CLEMATIS. Cal. none. Bloss. 4 petals. Seeds many; awned.

ANEMONE. Cal. nullus. Pel. 5-9. Sem. plurima.

ANEMONE. Cal. none. Bluss. 6 petals. Seeds. many.

CALTHA. Cal. nullus. Pet.quinque. Nect: nulla.

CALTHA. Cal. none. Bloss. 5 petals. Caps. mä. ny. Nectaries nane.

RANUNCULUS. Cal. pentaphyllus. Pet. quin. que, unguibus, nectariferis. Sem. plurima nuda.

RANUNCULUS. Cal. 5 (or 3 ) leaves. Bloss. 5 ( or 8) petals. Seeds many. Petals with a neciary in. - the claw. 


\section{POLYANDRIA.}

\section{MONOGYNIA.}

CHELIDGNIUM. Smith. 562. Win. 48 g. Cal. diphyllus., Petaía 4. Siliqua supera, bivalvis, unilocularis, linearis. Semina plurima, cristata.

Bloss. 4 petals. Cal. 2. leaves. Pod. strapshaped. Receptacle of lice seeds (generally) latnce-like.

\section{CHELIDONIUM.}

\section{Fruit-staln's forming ambels.}

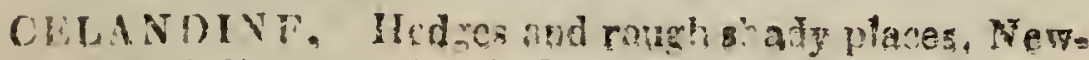
ark; Will's ol southwell Church-yard. P. May, June.

PAPAYER. Smith. 565. With. 485 .

Cal. diphyllus. Pelala 4. Stzoma radiatum. Capsula supera, sub stigmate persistente po. ris dehiscens.

Bloss. 4 petals. Cai. 2 leaves. Summit targetshapped, radiated, scolloped. Caps, (often) many-celled, opening winth holes underneain ihe permanent summit.

$$
\text { * Capsulis hispidis. }
$$

- Capsules rough wizh stiff bristly hairs.

P. capsulis clavatis hispidis, caule folioso Argemultifloro.

mone:

P. Capsules club-shaped, bristly; siem leafy。 many-flozuered. 
WE PULANDRIA. MONOGYNIA. Nympha

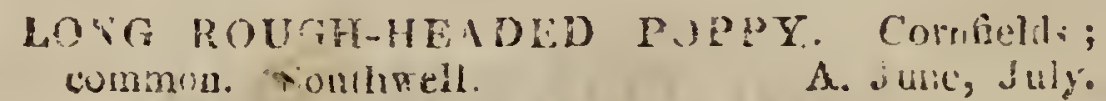
* Capsulis glabris.
a Capsules smooria.

Qubium. P. cadsulis glabris ublongis, caule multiflo.

$\therefore$ to piloso, setis peduaculosum adpiessis tulirs bipinarifidis.

P. Capsules oblong, smooth; stem many-fiow. ered: fiuzt-staliss watic brasties land to: leutes wing - cleft, sript.

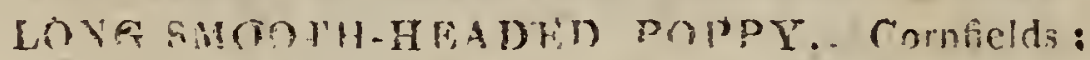
chietty in a lighe sandy soil. Blidworth. A. Junte, sulye.

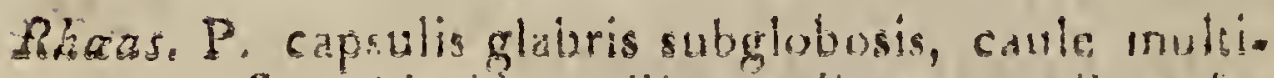
floro hispido: pilis omnibus patentibus, tro. lis pinndifidis incisis.

P. Capsules smooth, urn-shaped: stem hairy, many flowered: leaves wing cleft, jagged.

COMUON RED PCPPY, CORN ROAH. Amongst corn, aud borders of ficlds; comnon southweil; Newark. A. June, July.

NYMPH ÆA. Smith. 569. With. 483.

Cat. 4-5 phyllus. Cor. polynetald. Sirgma. radiatum, sessile. Bacca supề, multilucularis, polysperma.

Bloss many petals. Cal. 4 or 5 leaves. Sum. mit round, flat, suthng. Berry superiour, lupped, many-celled.

butea. - N. folis cordatis integerrimis, calyce pen. taphyilo potulis majore, stigmate inter rimo. 


\section{FOLYANDRIA. MONOGYNIA. Tilia. 16}

N. Leaves heart-shaped, very eniire: calyx 5-leaved, much larger than the petals.

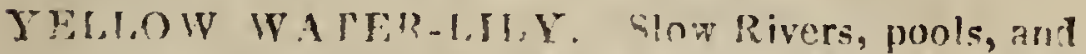
dicles. Riser Devon, Markian isridge, Nelvark; langlurd Flee"; Ditches in Collugham Meallow: Besilu:peblacs ponl; and in the sare istch, between Balderton and Claypole.

P. Juiy.

N. folis cordatis integerrimis. calyce tetra- alba: phyllo, staminibus germini insertis, stig. mate lobato.

N. Leaves heart-shiped, very entire: calys 4 .clift.

IVIITF W ATFP-IIILY. Slow Pivers, ponils and deen ditches. Imaford lact, near lewark, with $V$. lutea, plentifully: pion ts il the meadow betueen ( ol-

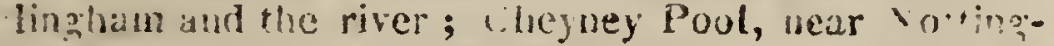
ham. !) E I I G.

P. July.

TILIA. Smith. 571. Wath. 490.

Cal. quinquepdrtitus. Petala 5. Capsula su. pera, coriacid, obovota, angulata, quinq"elocularis, quinquevalsis, basi dehiscens.

Bloss. 5 petals. Cal. with 5 divisions Seed vessel lexther-lue, globular, 5.celled, 5. yalued, opering at the base.

T. floribus nectarin destitutis, foliis cordatis, curo. ramificationibus venarum subtus villosis. paa.

T. Fiowers without a nectary: berry 4 -celled.

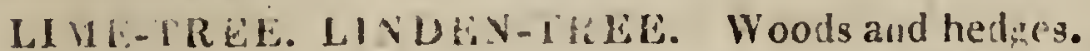
'. iuly.

CISTUS. Sinith. 572. Wïh. 490.

Cal. pentaphvilus: foliolis inæqualibus. $P_{C}$ tala 5. Cripsula supera, angulata, trivalvis, polysperma. 
Bloss. 5 petals. Cal. 5 leaves; 2 of them smaller. Caps. fiom 110 10-celled; from 31010 valued.

Stipulati suffructicosi.

Somewhat shrub like; wath stipula.

Helian-C. sufruticosus procumbens stipulatus, fo. themum. ins elifptico-oblongis subtus tomentoso- in canis.

C. Tranling: stipule spear-shuped: leaves oblong, edges rolled back, swmerahat hurry.

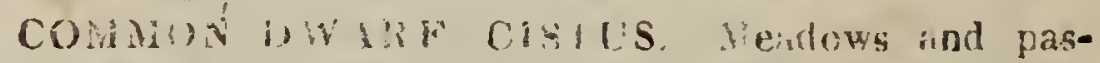
tures. in a catcarcous soil Sides of ixton llill, near the foll-bar.

i. Sily, August.

\section{PENIAGYMIA.}

AQUILEGIA. Smith. $57^{8}$. With. 495 . Cal. nulius. Petala 5. Nectaria 5, cornicu. lata, inter petala. Capsula 5. distinctie.

Calyx none. Petals 5. Nectaries 5, horn-shap. ed, alternatzng with the petuls. Caps. 5, dis. inct.

alga- A. nectariis incurvis vix petalis aqualibus, ris. caule fulinque glabris.

A. Nectaries boxied muards, nearly equal to the peials: leafils all on teaf-sialks, lubes aistant, roundish, blunish.

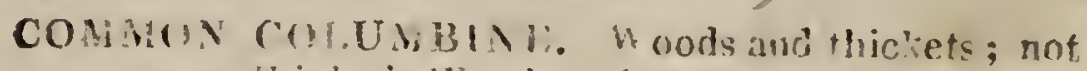
cormmon. "Iirley's 11 nod, at kroxtur. Asyly Wood, near Nottinghim. DoLkisG. J.Jul. 
POLYANDRIA. HEXAGYNIA. Stratiotes: 169

\section{HEXAGYNIA.}

STRATIOTES. Smith. 579. With. 495. Spatina diphylla. Perianthium superum, trifidum. Yetala 3. Bacca sexlocularis.

Sheath 2 leaves. Cup 3-cleft, or 3 leaves. Peials 3. Berry 6-celled; 6.curned: beneath.

S. foliis ensiformi-triangulis aculeato-serratis. aloides.

S. Leaves triangular-sword-shaped: edge fringed with prickles.

WATIR ALOR. WATLR-GOLDIER. SIow streams, and fen ditches; rare. Claypits; Stow Park, near Newton. Dr. Buck.

P. July.

\section{v POLYGYNIA.}

ANEMONE. Smith. 580 . With. 498 . Cal, nullus. Petala 5--9 Semina plura. Cal. generally none. Petals 5 to 10. Capsules many, with awns or tails for med by the style.

A. scapo involucrato uniforo, involucro tri-nemorophyllo petiolato folliaceo, seminibus ecau- sa. datis. folliolis incisis.

A. Sred's pointed: leafits snipt: stem with 1 flower. 


\section{POLYANDRIA. POLYGYNIA. Clematis:}

WOOD ANFMONE. Wonk, hedere, and hollonways; not uncommon. Thicheis near (Oxion lol!-bar; Fperstone; Oxton; Colwick, and broxtow Worils.

i. Aliril.

CLEMATIS. Smith. .583 . Witr. 500. Cal. nullus. Pet. 4-6. Semina caudata. Re. cept, capitatum.

Cal. none. Fetals 4 , rarely 5 or 6 . Siyles t permanent. Capsules many, wath tails. Receptacle a knob.

Vitalba. C. foliis pinnatis; foliolis cordatis: petiolis scandentibus:

C. Leaves winged: leafits heartishaped, climbing.

TRA YELLER'S JOY. Herres and sharly places, in - a calcareous soil. Here and there in hedges, hit rarely. Diвкім (;. S. July.

THALICTRUM. Smith. 583. With. 500. Cal. nullus. Petala 4-5. Semina ecaudata.

Cal. none. Petals 4 or 5. Capsules many, ra. ther beaked.

farum. T. follis bipinnatis: foliolis trifidis, caule sulcato, panicula ramosissima coarctata, floribus erectis.

T. Stem furrowed, leafy: leafits acute, 3cleft: panicle muck branched, upraght, com. pact: flowsers upright.

COMMON MEADOW-RUH. Moist meadows, pastures. and hanks of rivers. Newark and iverham Meadows; ditch banks beyond Newark Bridge on the Kelhain lozd.

P. july. 


\section{POLYANDRIA. POLYGYNIA. Ranunculus. 171}

RANUNCULUS. Simith. 587. With 503 .

Cal. pentaphyllus. Pctaía 5-8, intra ungues poromellifero. Semina nuda.

Cal. deciduous, 5 (or 3) leaved. Petals 5, (rarcly 2,3 or 8 ) with a neitariferous scale or pore within the claw. Styles permanent. Seeds incrusted, upright.

* Foliis simplicibus:

1 Leaves undivided.

R. follis ovato-lanceolatis obtusiusculis peti- Flaniolditis, caille declinato. mula.

R. Leaves egg-spear-shaped, on lenf.stalks: stem declining.

LESGLR SHAR-IVORT. Bogn, hoggy meariows,

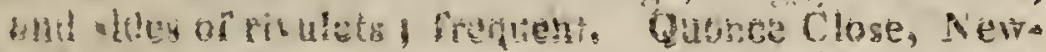
- atsing

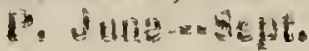

B. foliis lanceolatis acuminatis, catele erecto Lingus. mulitioro.

R. Leaves long spear-shaped: stem uprighto

GREAT SPTAR-WIRT. - Het mastures and sides of

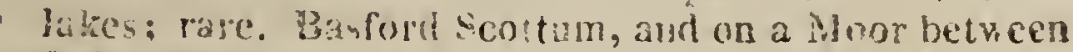
Britgetord and Samalon, coplously. De alk G. Althoush there does not appear to be any ground for inagi ing that Derking was mistaken, I have not been able to lind ths Pant in either of these situations. 1.1 is, howerer, not imposible, that it may still exist there. I have walieal neably so niles, to ascertain this single labitat, others maly be more foriunate.

P. July.

R. foliis cordatis angulatis petiolatis, petalis Ficaria. numerosis. 
R. Leavesheart-shaped, angular, on leaf-stalks: stem 1-flowered: flowers with 8 petals: calyx with 3 leaves.

PILEWORT. LESSER CFLANDINE. Meadows, pastures, hedge banks ; common.

P. April.

* Foliis dissectis et divisis:

2 Leaves dissected and divided, not uniform.

aurico- $\mathbf{R}$. foliis radicalibus reniformibus tripartitis mus. crenatis; caulinis digitatis linearibus, caule mintifloro, calyce colorato.

R. Root-leaves kidney-shaped, scolloped, cut: stem-leaves fingered, strap-shaped, stem many-flowered.

WOOD CROWFOOT. GOIDIIOCKS. Wonds, groves, and kediges. Southwell; Eyerstone.

P. April-..-May.

scelera. R. foliis inferioribus palmatus; summis diius. gitatis, fructibus oblongis.

R. Lower-leaves hand-shaped, the upper fingered: fruit oblong.

WATER-CROWFOOT. CELEITYLEAVED CROW-FOnT. shallow waters and ditches. Newark; Southwell; Nottingham. A. Jme---Aug.

bulbosus. R. calycibus retroflexis, pedunculis sulca. tis, caule erecto multifloro, foliis compositis, radice bulbosa.

R: Root bulbous: calyx reflected: fruit-stalks furrowed: stem upright, many-flowered: leaves compound.

BULBOUS CROWFOOT. BUTTER-CUPS. Meadows and pastures; very common. Newark; Southwell.

P. Mayo 


\section{POLYANDRIA. POLYGYN. Ranunculus. 17}

R. calycibus retrofexis acuminatis, caule erec- hirsuto mulufluro hirsuto, foliis terratis, radice tus. fibrosa.

R. Root fibrous: slem hairy: calvx pimpled, hazry, tuper, pointed, at length reflected.

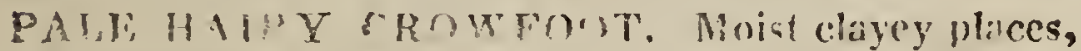
where whter has bont duting the winter; and horters of coatields. Sewark ; Souhwell; Nottingam.

A. June-.-Oc'oter.

R. calycibus patulis, pedunculis sulcatis, sar-repens. mentis repentibus, foliis compusitis.

R. Calyx expanding: fiuit-stalks furrowed: suckers creeping: leuves compound.

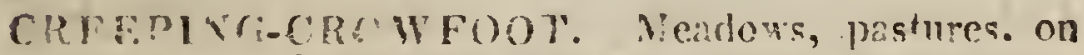

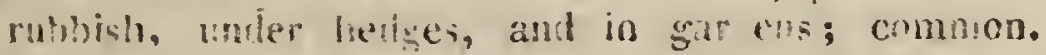

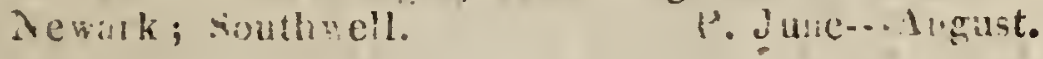

R. calycibuc patu'is, pedunculis teretius, fo- acris.

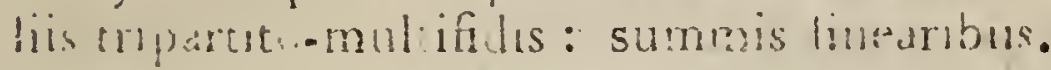

R. Culyx expanding: fiutit-stalis glindical: leaves with 3 "lizhsions, and manj clefts, the ufipermost strup shiaped.

U?

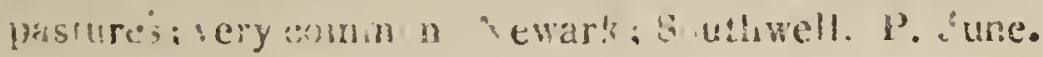

R. seminbu aculesti, fohis wifudecom-arvenpersitis: hachin hinearibua. sis.

R. Seeds prichiy: upper leaves doubly come pound, strup-shaped.

CORY CROAliour. Corlfeld; ommon. Newap's ; sonthroil. ; inte.

R. folis reniformi-suh tur dis uthobis quin-hedera.

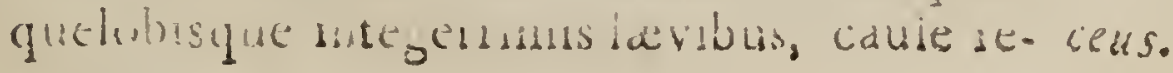
pente. 


\section{POLYANDRIA. POLYGYNIA. Caltha.}

R. Leaves roundish, z-lobed, very entire: stem creeping.

IVY CROWFOnT. On the mud of slow shallow streams, watery pluces, and di/ches. Eddingley Moors. quati-R. foliis submersis capillaceis : emersis sub. lis, peltatis.

R. Leaves under water hair-like: those above with nearly central leaf-stalks.

WATER CROWFOOT. Ponds and ditches. Kol. lows by the road hetween Newark-bridge and Muskham bridge, plentifully.

1.May--June.

CALTHA. Smith. 599. With. 5i1:

Cal. nullus. Petala 5. Neciaria nulla. Cap. sula pliorimæ, pulysperria.

Cal. none. Petals 5. Nectaries none. Caps. several; many-seeded.

palustris. CALTHA.

MARSH-MARIGOLD. Moist Meadows. Banks of rivers and pools common. Quonce Close, Niwarki Soutbirell. 


\section{DIDYNAMIA.}

\section{Classis XlV. DIDYNAMIA.}

Stamina 4, quorum \& longiora.

\section{GYMNOSPERMIA.}

Scmina nuda.

* Calyces subquinquefidi.

1 Cups mosily 5-cleft.

LEONURUS. Anthera punctis osseis adspersa.

LEONURUS. Anthers sprinkled with hard parii. cles.

GLECHOMA. Anth. per paria cruciatæ.

GLECHOMA. Anthers in purs; each pair form. ing a cross.

MENTHA. Fistomenta distantia, recta. Cor. suba. qualis,

MENTHA. Filaments distant: straight. Bloss. nearly regular.

TEUCRIUM. Cor. labium superius ultra basin bibartitum,

TEUCRIUM. Bloss, without any upper lip: upper. segment of the pecal divided. 
1,6 DIDYNAMIA. GYMNOSPERMIA.

BjUGA. Cor. lab. superius minimum.

AJUG 1. Bi iss upper lip shorter than the stamens. BETONICA. Cor. lab, superius planum, adscendens, tubo cylindrico. Stam. Iongitudine funcis.

BETONiCA. Bluss upper lip flat; ascending; Tube cyindrical. Stam. as long as the mouth of. the lutbe.

LAMITMI. Cor. faux utrinque dentata.

LPMIUM. Bhiss. with a brisile-shaped tooth on carth side the lizuer lip. (on earh sade the mouth.)

Githopsis Cor lab inferius supra bidentatum.

GALEOPSIS. Bloss wath a teeih upon the lower lip.

GALEOBDOLON. Cor. lab. inferius uifidum, lacmis acuis.

CALEOBDOLON, Blose. upper lip entire, valilt. cid; loner lip 3 cheft; segmenis broad, acule. Allthers fleshy on the back.

STACHYS. Cor. lab. inferius laterbus reflexum. Siam. deflorata an latera reflexa.

STACHYS Bluss lateral sesmeins of the lower. lip reflected. Stamens afler fluwering turned to the sides.

NEPETA. Cor. lab. inferius crenatum; faux margine refexe.

NEPETA. Bloss, lower iip scolloped. Mouth with the edge reflected.

BALL(:!A. Cal. decemstriatus. Cor. Iab. supe. rius forwicatum. 


\section{DIDYNAMIA. GYMNOSPERMIA, 177}

BALLOTA. Cup with 10 scores. Bloss. upper lip vaulled

MARRUBiUM. Cal. decemstriatus, Cor, lab. superius rectum, bifidum.

MARRUBIU.M. Cup with 10 scores. Bloss. up. per lip flat and straight.

VERBENA. Cal. unico dente truncato, Cor. su. brqualis, curva.

VERBENA. Bloss. nearly regular; upper segment of the cup shorter.

$$
\begin{aligned}
& \text { * Calyces bilabiati. } \\
& \text { 2 Cups 2-lipped. }
\end{aligned}
$$

SCUTELLARIA. Cal. fructiferus operculatus. SCUTELLARIA, Cup. afler flowering, closed with a cover, and resembling a helmet.

THYMUS, Cal. fauce villis clausus.

THYMUS. Cup. (moith small;) closed wilh sof hairs.

PRUNELLA. Filamenta omnia apice bifurca. PRUNELLA. Filaments all forked at the end.

ORIGANUM. Strobilus calyces coligens.

ORIGANUM. Cups forming a tiled cone:

CLINOPODIUM. Involucrum multisetum calyces colligens.

CLINOPODIUM. Cups, inclosed in an involwo crum. 
78 DIDYNAMIA. ANGIOSPERMIA.

\section{ANGIOSPERMIA.}

Semina pericarpio inclusa.

* Calyces quadrifidi.

1 Cups 4-rleft.

LATHR EA. Caps. unilocularis. Glandula sub germine.

LATHRAA. Caps. 1-celled. Bloss. gaping : o gland under the base of the germen.

BARTSIA. Capss, bilocularis. Sem.ang!lata.

BARTSIA. Caps. a-cellea. Bloss. gaping. Seeds angular.

RHINANTHUS, Caps, bilogularis, Sem, coms presses plana imbricata

RHINANTHU Gaps, galled. Calyx compress ed. Bluss. gaping.

MELAMPYRUM. Caps. bilocularis. Sem. bina, gibba, lievigata.

MELAMPYRUM. Caps. 2-celled. Bloss. gaping. Seeds 2 ; bulging.

EUPHRASIA. Caps. biloculariş Sem. siriata. Anth. spinua a.

EUHRASIA. Caps. 2ecelled. Binss. gaping: Lower Anthers with thorn.s.

* * Caigces quinquefidi.

2 Cups soricjt. 
LIMO iELLA. Capi. semibilocularis. Cor. campanulatd, subrequals.

LIMOSELLA. Caps. :-celled, many secded. Bloss. bell shaped; reyzular.

SCROPHULARIA. Caps. bilocularis. Cor. resupinata. Lab. segmento intemedio mterno.

SCROPHULARIA Caps 2-celled. Bloss. facing upwards; the lip with a madile segment more inward.

DIGITALIS. Caps. bilocularis. Cor. companulata, subtus ventricusa.

DIGITALIS. Caps 2.celled. Bloss. (tubular) bell-shaped; bellying on the under side. Stam. declinzing.

AN TIRRHINUM. Caps, bilocularis. Cor. personata, subtus nectario psominente.

ANTIRRHINUM, Caps. 2-celled. Bloss. gaping; wuth a projecting nectary beneath.

PEDICULARIS. Caps. bilocularis. Sem. mucronata. Cor. personata; galea compressa.

PEDICULARIS. Caps. 2-celled. Bloss. gaping. Seeds coatcd.

$$
\begin{gathered}
* * \text { Calyces subdiphylli. } \\
\text { 3 Cups cloven. }
\end{gathered}
$$

OROBANCHE. Cal. foliola lateralia, lubata. Caps. unilucularıs.

OROBANCHE. Caps, 1.celled. Blors, nearly equal; 4-cleft: a gland under the base of the germen. 


\section{\$80 DIDYNAMIA. GYMNOSPER. Ajuga..}

\section{DIDYNAMIA.}

\section{GYMNOSPERMIA.}

Calyces subregulares.

AJUGA. Smith.604. With. 516.

Corolla labium superius minimum, emargina. tum. Stamna labio supertore longiora.

Bloss. upper lip very small. Stamens longer than the upper lip.

reptans. A. glabra, caule solitario, stolonibus reptantibus.

A. Plant smooth; woith creefing suckers: leaves egg-shaped, scolloped.

COMMOY BUALE. Moist meadows, pastures, and wools; frequent.

P. May.

TEUCRIUM. Smith. 606. With. 518.

Corolla labium superius (nullum) ultra basin bipartitum divaricaium. Sramina exserta.

Bloss. upper lip upright, deeply divided, even below the base: stamens in the division.

scorodo- T. follis cordatis serratis petiolatis, racemis nia. lateralibus secundis, caule erecto.

T. Leaves heart-shaped, serrated, on leafstalks: flowers in lateral bunches, pointang one way: stem upright.

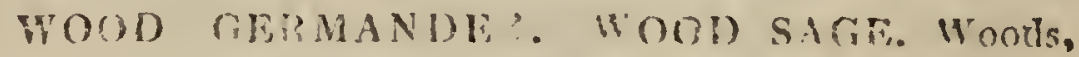
liesths, thickets, and dich hanks; not tencommon. On lhe hining ruchs oier the leen, in tortuntham Park; batks between Letford and Worisop. E. July. 


\section{DIDYNAMIA. GYMNOSPER. Verbena. 181}

\section{NEPETA. Smith. 608. With. 519.}

Corolla labium inferius lacinula intermedia cienata: faux margine reflexu. Stamina approximata.

Bloss. middle segment of the lower lip scollop. ed; mouth the edges reflected: stamens approuching.

N. foribus spicatis, - certicillis subpedicella-cataria. $\mathrm{t} 1 \mathrm{~s}$, foliis petiolatis cordatis dentato-serratis.

N. Flowers on spikes: whirls on short fruitstalk: leaves on leaf-stulks, heart-shaped. tooth-serratid.

NFP, or CAT-NINT. Hedges in a calcareous soil; no frequent. On Banlis herween tewark and Hawton; lialh at thansfell; in a lledge on the right-band-side of the locid leailing from Cuckuey to Warsop.

$$
\text { P. July. }
$$

VERBENA. Smith.608. With. 520 .

Cor. infundibuliformis, subæqualis, curva. $C_{a}$ lycis unico dente truncato. Sumna 2 sive 4. tenuissime arillata. Semina 2 sive 4.

Blors. funnel-shaped; segments nearly equal. Calyx one of uts teeth lopped. Seeds 2 or 4 , naked.

V. tetandia, spicis filiformibus paniculatis, fo- offeilis mulutide-laciniatis, caule subsulitario. nalus.

V. Spizies thicad-shaped, pancled: lenves with many jugged clifts: stem solitary.

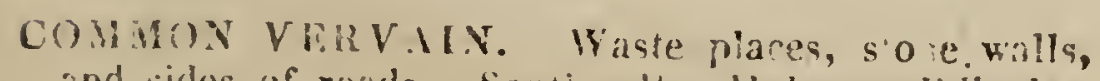

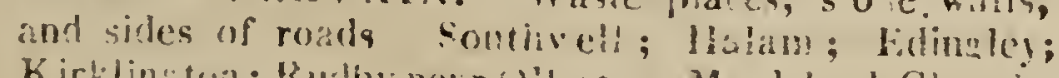
Kirtilin;win; Rudby near Bhlerton; Minglebeck Churchjül. 
MENTHA. Smith.609. With. 521.

Cor. subæqualis, quadrifida; lacinia latiore emarginata. Cal. quinquefrdus. Stam. erec. - tax, distantia.

Bloss. nearly equal; 4-cleft; the broaier seg. ments notched at the end. Stam. upight, distant.

sylues. M. spicis villosis subcontiruis, foliis dentatc-

tras. serratis subtus pracipue conemtosis, bracteis subulatis.

M. Spikes oblong: leaves oblong, serrraled, cottony, stlting: stamens lunger than the blossom. LIN.i.somelimesnotlonger. HuDS.

HORSE MINT. Marshy and watery pluces; somerhat rare. Cireet Bridre, Southwell: Grent Dichas, near Newark Briage; Mansfield Bath; Thurarton Hill.

3. Aigris, sipt.

rotundi-M. spicis subhirsutis interruptis, foliis ellipfolia. ticis obusis rugosis crenatis subus villusis, bracteis lanceolatis.

M. Spikes oblong: leaves roundish, scolloped, sitting.

ROU:D-L,F\V:D MIYT. Watery places; rare, Aeur the Buth at Manstield. DeErrsig. MiAktY

P. Augusl, sept.

piperita. M spicis obtusis interne interruptis, foliis periolda is subovatis glabriusculis, calyce basi glaberriono.

MI, Ieaves rgg-shaped, on leaf-stilks: stamens shorter than the blus som.

PrPPi:R-Vil YT. Watery places. By the sille of the Greet, acar the Water-mill, at Solatwell. P. Ang. Sept. 
DIDYNAMIA. GYMNOSPER, Mentha. 183

M. Roribus capitat is verticillatisve, foliis pe- hirsuta. tiolatis ovatis, calyce undique hissuto, pedicellis retrursum hrspidis.

M. Leazes egg.shaped, serrated, nearly sit-. ing, downy: siamiens longer than the blos. soin.

HAIRY MINT. Siles of rivers, and wet placen.

P. Ausut, "ept:

M furibus verticillatis, foliis ovatis, caule gentilis. ramosissimo patulo, calycibus basi pediccllisque glabris.

Ni. Leaves egg-siaped, acuie, serrated: siamens shorter than the blossom.

BUSAlX kED MINr. Watery pheses, and sides of rivulets. Newark; Southwell; Mandield. P. Aug.

M Aoribus renicillatis, foliis ovatis, caule arven ramosissim, calycibus caimpanulatis un- sis. dique hirrutis pilis lorizontalibus.

M. Leaves egg-shaped, acute, serrated: sta. mens as long as the blossoms.

CORY MITT. Waiery plices, and moist comfel!'s. Newark; Southwc!l. P. June---Sept.

M. floribus verticillatis, foliis ovatis, caule Pulegiprostrato, pedicellis calycibusque undique um. tomeritosis: dentibus ciliatis.

Mi. Leaves ergr-shaped, blunt, someruhat scolloped: stems roundish, creeping: stamens longer than the bloss.

PISNY ROYAl. Moist heaths and pastures; not common. Kirklington Water Mil! Wellow Green, and civathorge. Hesendis.

P. septeraber. 


\section{DIDYNAMIA. GYMNOSPER. Glechoma.}

GLECHOMA. Smith. 625. With. 52.5. Cal, quinquefidus. Anthera per paria in crucem conniventes.

Cal. 5.clift. Anthers in pairs, each pairforming a cross.

hedera. G. foliis reniformibus crenatis.

rea. G. Leaves kidney-shaped, scolloped.

GROUND-IVY. Glli. Als,HOOF. Groves, hedges, and shady places; very $\mathrm{crm}$ on.

P. April, Maj.

LAMIUM. Smith. 626. With. 526 .

Cal. quinquefilus, dentibus setaceis patentibus. Cor. labiam superius integrum, fornicatum: inferius bilobum; faux inflata, utrinque margine dentata.

Bloss, upper lipentire, vaulted; lower lip inversely heart-shaped: mouth with a bristle. shaped toolh on each side.

album. Lo foliis cordatis acuminatis petiolatis, verticillis vigintifloris.

L. Leaves heart-shaped, tapering to a point, serrated, on leaf-stalks: flowers about 20 in a whirl.

WMTE ARCIANGFl. WMTEDEID NFT. TI.E. On rubbish, comfielis, and ditch bunlis; con?mоล.

P. May, june.

purpu. L. foliis rordatis obtusis petiolatis: superireum. oribus confertis.

I. Leaves heart-shaped, blunt, on leaf-stalks.

RVD ARCHANGit. Rubhish, comtields, and hit. chen gardens; common.

A. Hay-..sert. 


\section{DIDYNAMIA. GYMNOSPER. Galeopsis. 185}

L. foliis fforalibus sessilibus amplexicaulibus amplexobtusis.

L. Flord-leaves sitting, embracing the stem, blunt.

IIINBIT, ARCIIANGEI. GREAT IIENBIT. Corntields, and cultivated groundis ; not uncornmo?. Soutinell; vewark.

A. Ireb.-.-funte.

GALEOPSIS. Smith. 628. With. 528 .

Cal. quinquefidus, aristatus. Cor. labium superius crenatum, fornicatum; inferius supra bidentatum.

Bioss. upper lip vaulted, somewhat scolloped; lower lip 3-cleft: mouth with a concave taper-pointed looth on each side.

G. internoliis caulinis æqualibus, foliis ova-villosa.

to-lanceolatis serratis villosis, corollex galea crenato-incisa.

G. All the whirls remote: calyxes tubular, very hairy; teeth spear-shaped, taper-pointed, short, straight.

G. grandiflo a. With.

UOU YY HEM -NETTLE. Sandy cornfields; nnt very common Cormfeids at Farn field, Budderten, Barn'y, and loddington. i. July, August.

G. caule hicpido: internodiis superne incras- Tetrasatis, curolla calyce duplo longiore, galea hit. rectiuscula.

G. Upper whirls nearly contiguoüs: cal's bellyzing; teeth very long, brisile-shaped, equal: stem suollen below the joints.

ComMiU: HEMP-YUTTLE. Hedge hanks, borders of cornfielts, and anjongst rubbish; coinmon. Neware; Soltisuct. A July, August. 


\section{DIDYNAM. GYMNOSPER. Galeobdolon.}

versi- G, caule hispido: internodiis superne incrascolor. satis, corolla calyce triplo longiore: galea ventricosa.

G. Upper whirls nearly contiguous: caly'x tubular, shorter teeth strap-shaped, unequal, 3 of them larger.

G. cannabina. With.

I.ARGE FLOWERED HFMP-NETTLR. BFENETTLF. Corn-fields, turnoficle, and fallow grounds; not very common. Farusfield, Ramby, Balderton, and Coddington.

A. July, Angust.

GALEOBDOLON. Smith. 631. Wilh. 530.

Cal. quinquefidus, inæqualis, aristatus. Cor. labium superius integcrimum, forticatum; inferius trifidum, laciniis omnibus acutis.

Bloss. upper lipentire, vaulted; lower lip with. out teeth, 3-cleft; segments broad, poinied. Anthers fleshy on the back.

\section{luteum. GALEOBDOLON.}

YFILOW DEAD NETTLL. WEAZLF-SNOUT. Woods, shady !laces, and moist hedges. Westhorpe Dumble, nar fou hell ; and in the wols, at Plintham, Liperstone, Ossington, and Colwick. 1'. Nay.

BETONICA. Smith. 632. With. 531.

Cal. quinquefidus, aristatus. Cor. labium superius adscendens, planiusculum, inferius trifidum: tubus cylindricus.

Calyx awned. Bloss. upper lip upright, flat; tube cylindrical.

officina- B. spica interrupta, corollarum lacinia la. lis. bii intermedia emarginata. 
DIDYNAMIA. GYMNOSPER. Stachys. 187

B. Spitie interrupied: blossom upper lip entire, lower lap the indale seginent nothed: calyaes sinoothish.

WOAD Pi:TOYY. Wooda all shady gores. Tn Mr.

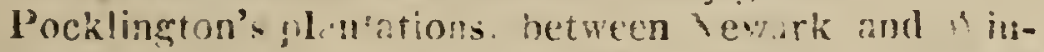

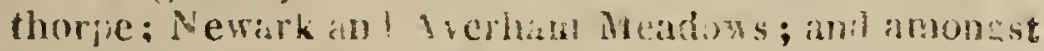
gorse in the labe tetween Baklertors and rodlingron. P. inly...-August.

\section{STACHYS Smith.632. With. 531.}

Cal. quinquefidus, aristatus. Cor. labiun su. perius fornicatum: inferius lateribus reflexum, lacinia intermedia majore, emarginata. Stamina deflorata versus la:era reflexa.

Bloss. Upper lip vaulted; lower lip bent back at the sides, the larger mia'dle segment notch. ed: stamens after shedaing the pollen bent to the sides.

S. verticillis sexfloris, foliis cordatis petiola- sylua. tis

S. Six flowers in a whirl: leaves heart-shaped, on leaf-stalks.

II HBCE WOUNDWORT. Helges and woods; common. Newark.

P. July.---nugust.

S. vericillis sexfluris follis lineari-lanccola- palus. tis semiamplexicaulibus.

S. About six flowers in a whirl: leaves strap. spear-shaped, half embracing the stem, sitting.

MARSH WOUNDWORT. Watery places andbanks of rivers. Banks of the Greet Sonthwell ; dilches near the Meadows at Newark; ditches on the road between Ratcliff and Nottingham.

P. August. 


\section{DIDYNAMIA. GYMNSSPER. Ballint}

arven-S. verticillis sexforis, caule debili, foltis corsis. datis obtusis crenativ subpilosis.

S. Six flowers in a whirl: leaves blunt, almost nuked: blossoms as long as the calyx : stem feeble.

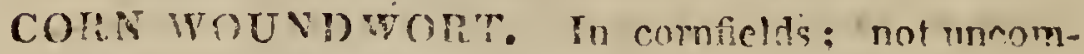
mon. About Codding̈ton; near Farnsfield Rrick-Kilns.

A. July.-.-August.

BALLOTA. Smith. 635. With. 533 .

Cal. hypocrateriformis, decemstriatus, quin. quedentatus. Cor. labium superius crena. tum, concavum.

Calyx salver-shaped, with 5 teeth and 10 scores. Bloss. upper lap concave, scolloped.

migra. B: foliis ovatis indivisis serratis, calycibus superne dilatatis suboruncatis : dentibus patentibus.

B. Leaves heart-shaped, undivided, scrraled: calyx teeth tapering to a point.

EASC OSTINRING HOREAOUND. On rubbisht and in hedres; very conmon. P. July...-Aig.

MARRUBIUM. Smilh. 635. With.533. Cal. hypocrateriformis, rigidus, decemstriasus. Cor. labium superius bifidum, lineare, rectum.

Calyx salver-shaped, rigid, with 10 scores. Bloss. upper ip cloven, strap-shaped, straight.

vulgare. M. dentibus calycinis decem setaceis uncinatis. 
M. Teeth of the calyx brisile-shaped, hooked:

WHITE HORFllOUND. rioald sides, and amongst rubhich. In the roall leating from Blidenoth to Kirkly; also about Baluell Stonc-jis : on :he rinht hand side of the road from Wortisop to Ollerton. P.July.

LEONURUS. Smith 637. With. 534.

Cal. pentagonus, quinquedentatus. Cor labium superius concavum, villosum, integrum. Anthera punctis nitidis adspers

Anthers sprinkled with shining particles.

L. folins superioribus lanceolatis trilobis inte-Cardi. grisve.

aca.

L. Siem-leaves spear-shaped, 3 -lobed.

HOTHER WORT. Hedges and on rubbish and dunghills. On rubtich by the road side a little beyond. Manafield, on the Chestertield road; hedge botings of a garden belonging to Mr. Brown, at the 3 mile house on the roud iro.n Newark to Lincoln. P. July.-.-Aug.

* Calyces bilabiati.

CLINCPODIUM. Similh 638. With. 534 . Cal. bilabiatus. Involucruin multisetum ver. ticillo subjectum.

Stamens crooked. Anthers aphroaching. Involucr. bristle-shaped, beneath the whirls.

C. verticillis hispidis, bracteis setaceis, pedi-vulgare. cellis ramosis, folliis obsolcte serratis.

C. Heads roundish, hispid: floral-leaves bizstle-shaped.

WII, PASIL. Mcarows, hedgcs. and dry patures, esperially in a calsuren!s soil. Road between outhwell and Oxton: bise be? ers Oxton and (alverton, and in the road between Redford and horisop. plendifully.

B. + tugurs. 
IgO DIDYNAMIA GYMNOSPER. Origanum.

ORIGANUM. Smith. 638. With. 535. Strobilus tetragonus, spicatus, calyces. colligens:

Flowers forming a 4 sided spike like cone.

vulgare. O. spicis subrotundis paniculatis conglomeratis glabris, involucris ovatis calyce longioribus.

O. Spikes roundish, panicled, clustered: floral. leaves egg.shaped, longer than the calyx.

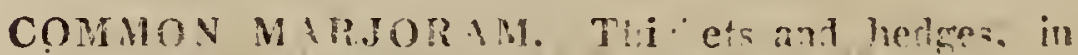
a calca eons sul!, On banks in a line leading to Chitnook closes; no he Binderion ruat from Vewart; in fields about Codfingion. Jily,... Airgtist.

THYMiUS. Sinith. 639. With. 5,36 .

Cal. bilabiatus, faux villis clausa. Cor. labiun superius ylanum, emarginatum.

Calyx 2-lipped; mouth closed with soft hatrs. Ser $b_{y}$. T. floribus capitatis, caulibus decumbentitun. bus, follis planis ovatis obtusis basi ciliatis.

T. Flowrers in heads: stems creeping: leaves flat, blunt, fringed at the base.

WILD THYRIS. MOPHER of THYMIS. Mesthe aml mountainous places. Not!ingham l'arli; Stierruot' Folest.

T. Serpyllun citratum. Lemon Thyme.

1.eves with the scrnt of lemen pect. About fir lirchald rythom's Tedsle on sherwood forest ; in a close of the onclies, frormanton; fdingley hoors.

1. July, August.

Acinos. T: verticillis sexfloris; pedunculis simplici. bus, caule adscendente amoso, foliis acu. tis. serratrs, calyce gibboso. 


\section{DIDYNAMLA. GYMNOSPER. Scutellaria. 19"}

T. Flower in whirls; 1 upon each fruit stalk: stems upright, sonewhal branched: leavies acute, serrated.

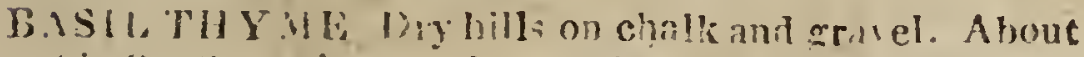

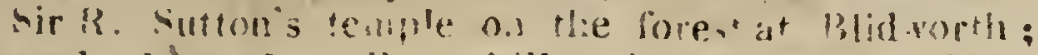

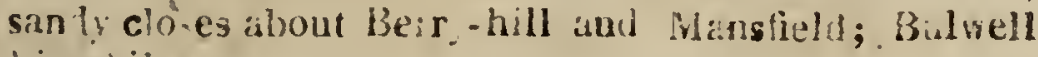
Lisièilns.

T. verticillis pedunculat is multiforis dicho-Calamintomis, folis subseratis, villis calycinis tha. inclusis.

T. Frunt stalks axillary, forked, as long as the leaves.

Melissa Culmintha. Lixn. With.

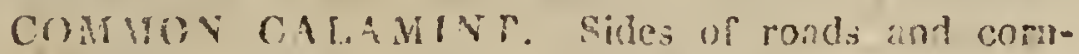

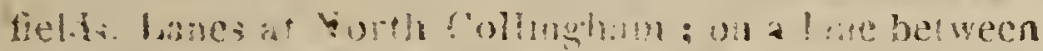

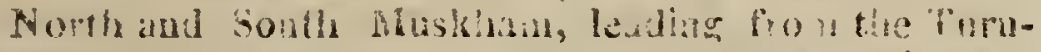
pike. Wuly...-Auguzt.

$T$. verticillis pedunculatis multinoris dichoto. Ápets. mis folio lougiorbus, folits seratis, villis calycinis prominentibus.

'T. Finit-sralks axallary, forked, longer than the leaves: stem ascending, hairy.

Melissa Nepeta. LINn. Whth.

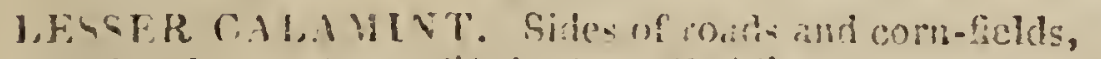

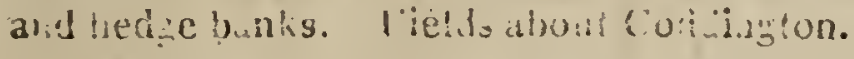

SCUTELLARIA. Smin. 6.15. Whin. 5 .

Cal ore subint gro: post flore centiain clauso operculato.

Caly x rim nearly enire, closed after flowering: cozered wulh a lid.

S. foliis cordato-lunceulatis crenatis rugosis, galerifloribus axillaribus. 


\section{Ig2 DIDYNAMIA. GYMNOSPER. Prunella.}

S Leaves heart-spear-shaped, sculluped: flowers axillary.

COMMON SKULA-CAP. Banks of rirers and plees of wonds. Ditch banks hy lla side of the roan frow

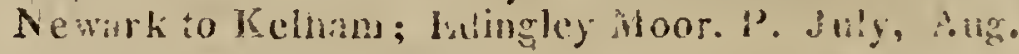

PRUNELLA. Smith. 646 With. 540.

Filamenta bifurca, aitero apice antherifera. Stigma bifium.

Filaments forked one of the divisions bearing the anthers summit cloven.

ulgaris. P. foliis omaibis ovato-oblungis petiolatis.

P. All the leaves egg-oblong. serrated, on leafstalks; upper lip of the caily lopped, 3 . tooiked.

Si.LF IIFAL. Mearlows ari nasties; not conmon. Sombive!l; Newark; Nottughan. i'. July, Rus.

\section{ANGIOSPERMIA.}

1 Calyces quadrifidi.

BARTSIA. Smith 647. With. 5i1.

Cal. quadribubus, subcoloratus. Cor. ringens, fauce clausa: labrum superius concavam, longius; inferius aqualiter trifidum, refiexum. Cupsula orata compressa, bilocularis. Semina plurima, angulaia.

Calyx 2-lubed, notched at the end, the prints (sometumes; colnured. Bloss. (sometumes) less coloured than the calyx; the upper lip longer. Capsite a celled. 
B. foliis lanceolatis serratis : superioribus al. Odoniternis, 'floribus racemosis secundis, anche- tes. ris glabris.

B.' Upper leaves allernate. spear-shaped, serrated: flowers an bunches, pointing one way. Euphrasia Odontitis. Linn. With.

RED BASTIA. Cornfilds and pasture:; common. Newär'; Southell. A. July, August.

RHINANTHUS. Smith. 649. With. 542. Cal. vertricosus, quadridentatus. Cor. galea compressa. Caps. bilocularis, obtusa, compressa. Semina inbricata, compresso-plana. Calvx 4-clefi, inflated. Capsule z-celled, blunt, compressed. Seeds few.

R. corvllie labio superiore fornicato, calyce Cristaglabro, foliis lanceulatis serratis.

R. Upper lip of the blossom compressed, and shorier: calyx sinosith.

YELLOW RAPILE. Meadons, pastures, and woods; conmon. Southwell; Niewark.

A. June.

EUPHRASIA. Smith.650. With. 543 . Cal. cylindricus, quadridentatus, æqualis. Cor. labium superius bifidun; interius trilo. butm, laciniis bifidis. Anthera spinis inæqualibus anistata. Caps. ovato-oblonga. Semzna striata.

Cal. 4-cleft, cylindrical. Anthers, the lower ones walh one thorny lobe at the base. Caps. 2-celled, egg-oblong. Seeds feu leaning backwards. 
offici- E. foliis ovatis lineatis argute dentatis.

nulis. E. Leaves egg-shaped, streaked, sharply tooth. ed.

EYF-BRIGHT. Heaths, dry barren mealows and pastures. Newark; Southwell. A. July-.-Sept.

MELAMPYRUM. Smith. 651. With. 544. Cal. tubulosus, quadrifidus. Cor. labium superius compressum, margine replicato. Crps. bilocularis, obliqua, hinc dehiscens. Semina billa, gibba.

Cal. 4-rlejt. Bloss. upper lip compressed, edges bent back. Caps. 2-celled, compressed, slanting, opening on one side. Seeds solzta$r y$, bulging.

pratense. M. floribus secundis lateralibus: conjugationbus remutis, corollis clausis labio porrecto.

M. Flotuers lateral, pointing one way; leaves in distant pairs: blossoms closed.

COMMUN YELLOW COW-WHEAT. Woods and thichets. Ejerstone Thickets, near Oxton.

A. 'Uly, August.

LATHR EA. Smilh. 654. With. 547.

Cal. quadrifidus. Glandula depressa ad basin suturæ germinis. Cups. unilucularis, receptacuilis fungosis lateralıbus. Semena globosa.

Culve with 4 or 5 tivinsions. Germen with a dipreised glind ai the ouse (1) the seam. Caps. 1-cclled: recopiacles iaierul, sponge like. 
DIDYNAMIA. ANGIOSPER. Pedicularis, 195

L. caule simplicissimo, foribus pendulis la. Squabio inferiore trifido.

L. Stem undivided: flowers pendent; lower lip 3-cleft.

GRTATER TOOTH-WORT. In shady places, but viry rare. At lhe roots of 2 large elun trees, in the garden of WuLIAM SHEFBROOKE. Ps. it Oxton; and on the roofs of the hazels ver tise stews at Orion. Wis. SnLPlinork.

P. April.

$$
\text { * * } 2 \text { Calyces quinquefidi. }
$$

PEDICULARIS. Smith. 655. With. 548.

Cal. subquinquefidus, ventricosus Cor. galea emarginata, compressa. Caps. bilocularis, mucronata, obliqua. Semina pauca, angulata, mucronata.

Calvx 5.cleft. Caps e-celled. sharp.pointed. slantzing. Seeds few, couted.

P. caule solitario ramoso, calyce ovato piloso paluso costato bilobo inaqualiter inciso.

tris.

-P. Stem branched: calvx cresied with caltous dots: lip of the blossom slanting.

MARSH LOUSEWORT. Mirhes, ditchea, moist mearlows, and pastures. Oxton Buttoms; Ldingley Moors.

P. caulibus pluribus simplicibus patentibus, sylvatio calyce oblongo angulato glabro inæqualiter ca. quinquelobs inciso.

P. Stem branched: calvx oblong, angular, smooth: lip of the blossom heart-shiped.

PASTURE LOUSEWORT. Wet pastures and heaths. Coddington, Stapleford, and Langford Moors ; Park at Southwell; Oxton; Papplewick. P. June, July. 
×6 DIDYNAM. ANGIOSPER. Antirrhinum.

ANTIRRHINUM. Smith. 656 . With. 549 .

Cal. quinquepartitus. Corolla basis deorsum prominews, neciarifera. Caps. bilucularis. Calyx with 5 divisions. Bloss. "either bulging at the base; or ending in a spur. Caps. 2. celled, many seeded, "pening at the 1op, and the divisions bent back.

* Foliis dilatatis, caulibus laxis.

1 Leaves angular.

Cymh-A. foliis cordatis quinquelobis alternis gialarza. bris, caulibus procumbentibus.

A. Leives heart-shaped, 5-lobed, aliernate: steins tralling.

IVY-LA VED SY AP.DRAROY जit walls. Walls of the Lhurchyard at southwell; Kirkhy Church

p Mat.... ovemher.

syurium. A. foliis ovatis alternis, caulibus procumbenwhus.

A. Leaves egg shaped, woolly: stem irailing.

ROUND LEAVED RLUELA, Comfields; not frequent, A iton Hill. DEERisg. A. July-a-Seyt.

* Foliis angustioribus, caulibus erectis.

2 Leaves aliernate.

Linaria. A. foliis lanceolato-linearibus confertis, caule erecto spicato, calycibus glabi is calcari brevioribus.

A. Leaves spear-strap shaped, crowded: stem upright: spikes terminating, sitting: flowers tiled. 


\section{DIDYNAM. ANGIOSPER. Scrophularia. 198}

\section{COMNON YELLOW TOAD-FLAX Barren mea-}

dows, pastures, and hedges; common. Southwell; Newark; Mansfield.

P. June, July.

A. foliis plerisque alternis lanceolatis obtùsis minus? pubescentibus, caule ramosissimo patulo calycibus calcari longioribus.

A. Leaves mostly alternate, spear-shaped, blunt: siem very much branched, spreading.

LEAST SNAP-DRACBON. Gravelly cornfields; not common. Fields by the sidc of warsop Wood.

A. June---A igust.

* * Corollis ecaudatis.

3. Bloss. gaping: without a spur.

4. corollis ecaudatis, floribus spicatis, caly-majus. cibus obtusis villosis.

A. Blossoms without a spur: flowers in spikes: eups rounded.

GREAT SNAP-DRAGON. Old walls. On the Walls - of the Friars; Newark.

P. July, Aurust.

SCROPHULARIA: Smith. 662. With. 553 . Cal. quinquefidus. Cor. subghlobosa, resupinata. Caps. "bilocularis.

Cal. 5-cleft. "Bloss, with 5 divisions; "tube globular; the lower segment reflected. Capso 2-celled, partition doüble.

S. foliis cordatis acutis basi trinervibus, caule nodosa. acutangulo.

S. Leaves oblong-heart-shaped, 3-fiored at the base, corners of the siem acute. 
198 DIDYNAMIA. AṆGIOSPER. Digitalis.

KNOTTY-ROOTED FIGWORT. Woods and moist hedges. Halam and Edingley Hills; Thicke?s near Oxtou Toll-bar; Fiperstone and Colwick Woois.

P. July.

aquatica. A. foliis cordatis petiolatis decurrentibus obtusis, caule alato.

S. Leaves heart.shaped, blunt, on leaf-stalks, running down the stem: corners of the stem edged wuth a membrane: bunches terminating.

WATER FICWORT. WATER BETONY. Watery places, and banks of rivers; very common. Newark; Southwell.

P. July.

DIGITALIS. Smiih. 665. With. 555 .

Cal. quinquepartitus. Cor. campanulata, quinquefida, ventricosa. Caps. ovata, bilocularis, polysperma.

Cal. with 5 divisions. Bloss. bell-shaped, 5-cleft, bellying. Caps. egg-shaped, 2-celled, many-seeded.

purpu. D. foliolis calycinis ovatis acutis, corollis obrea. tusis: labio superiore integro, foliis pubescentibus.

D. Segments of the calvx egg-shaped, acute: blossom blunt, upper lip nearly entire.

PURPLE FOXGLOVE. Hedge hanks, and sides of bills in dry gravelly or sandy soil; not uncommon. Sherwood forest.

B. June, July.

IIMOSELLA. Smith. 668. With. 557.

Cal. quinquefidus. Cor. quinquefia, subzqualis. Stam. perparia approximata. Caps. ovato, unilocularis, bivalvis, polysperma. 
DIDYNAMIA. ANGIOSPER. Orobanche. 199

Cal. 5-cleft. Bloss. 5-cleft, equal. Stamens approaching, in pazrs. Germen 2-celled. Caps. ofien 1-celled, 2-valv'd, many-seeded.

LIMOSELLA:

aquatica.

MUDWORT. Muddy and graselly places, where menter has stagnated during the winter; not very common. Gravel-pits, near Kirklington Mill. P. July, Aug.

* * Calyces subdiphylli.

OROBANCHE. Smith. 668. Wit' 557.

Cal. foliulis duobus, lobatis, lateralibus. Cor. ringens Caps. unilocularis, bivalvis, po. lysperma. Glandula sub basi germinis.

Cal. somewhat cloven. Blośs. gaping Germen resting on a gland. Caps. 1-celled, 2valued, many seeded.

* Bracteis solitariis.

O. caule simplici, corolla inflata: labii laci- major. niis acutis æqualibus, staminibus glabris, stylo pubescente.

O. Stem unbranched, pubescent: stamens the length of the blossom.

GRFATER BROOM-RAPE. Sharly places at the roots of trees; somewhat rare. 'Two plants among broom, about half-way between Retford and Worksop, in a Plantation of Farl Manvers, at Thoresby ; Manzer Gorze, left-hand side leading into Dillenah Wood, near Winkburn.

P. June, July. 


\section{Classis $X V$.}

\section{TETRADYNAMIA.}

Stamina 6, quorum 4 longiora.

\section{SILICULOSA.}

- Pericarpium subrotundum. Pouch not notched at the end.

DRABA. Silicula integra, valvis planiusculis, dis. sepimento parallelis.

DRABA. Pouch with nearly flat valves. Style none.

COCHLEARIA. Silic. subintegra, turgida, rugosa, bivalvis, polysperma.

COCHLEARIA. Pouch heart-shaped. Valves blunt; bulging.

CORONOPUS. Silic. subintegra, compressa, corrugata, evalvis, disperma.

CORONOPUS. Pouch nearly entire, compressed, wrinkled; without valves; with 2 seeds.

THLASPI. Silic. emarginata, obcordata; valvulis marginato-carinatis.

THLASPI. Pouch inversely heart-shaped. Valves (in some species) bordered; keeled. 
TETRADYNAMIA. SILIQUOSA. 20

IBERIS. Silic. emarginata, ubcordate. Pet. duo exteriora majora."

IBERIS. Two outermosi petais the largest.

\section{SILIQUOSA.}

Pericarpium longissimum, polyspermum.

* Calyx clausus, fuliolis longitudinaliter conniven. uhus.

1 Cup closed; the leafis approaching length ways.

RAPHANUS, Slizqua tniosa, smborticulata.

RAPHANUS. Pot jumed.

ERYSIMUM. Saliqua tetragona.

ERYSIMUM. Pud 4-cornered.

CHEIRAN THUS. Germen urinque glandula no. tatum. Sem. p end.

CHEIRANTHUS. Germen with a gland on eac/s side 2 " base.

ARABIS. Gland quatuor, reflexa. Siliqua linearis turulosa.

ARABIS. Glands 4 ; within the leafits of the cup. Summit undivided.

TURRITIS. Siliqua stricta, subangulata, Cor。 erecta.

TURRITIS. Petals upright. 
BRASSICA. Siliqua teretivscula. Sem. globosa. BRASSICA: Glands, 2 withen the shorter stamens: 2 on the outside the longer stamens.

* Calyx hians, foliolis superne distantibus.

2. Cup open, the leafits wide asunder upwards.

CARDAMINE, Saliqua elastice dissiliens, valvu. lis revolutis. Stigma integrum. Cal. subhians.

CARDAMINE. Pod opening. Valves rolling back. SISYMBRIUM. Siliqua dehiscens valvulis rectiusculis Cal. patulus.

SISYMBRIUM. Pod opening. Valves nearly straight Cupopen.

SINAPIS Siliqua teretiuscula, dissepimento prominente. C'al. horizontaliter patens.

SINAPIS. Yod opening. Cup expanding horizon. takly.

\section{TETRADYNAMIA.}

\section{SILICULOSA.}

DRABA. Smith. 677. With. 565 .

Selicula integra, ovali-oblonga : valvulis planiusculis, dissepimento parallelis, Stylus vix ullus.

Pouch entire, elliptical-oblong, rather compressed. Valves flat, parallel to the par. titron. Style none. 


\section{TL 1 KADYN. SILICULOSA. Thlaspi, 203}

D. seapis nudis, petalis bipartitis, foliis lan- verna. ceolatis subincisis hirtis.

D. Stalks naked: leaves sparingly serrated: petals divided.

COMAION WIII ILOW-GRASS. Walls and dry places; common. Newark; Southwell. A. March--April. THLASPI. Smith. 683. Wath. 568.

Silacula emarginata, obcordata, polysperma: valvulis navicularibus, marginato-carinatis. Pouch inversely heart-shaped, notched at the end. Valves like a keeled boat, often winged wath a border: cells many seeded.

T. siliculis orbiculatis compressis lævibus, arvense. foliis oblongis dentatis glabris.

T. Pouches round and flat: leaves oblong, toothed, smooth.

PENA Y CRLSS. SWOOTH MITHRIDATE MUSTARD. Cornfields, and amongst turnips. Fields between Sutton-upon-Trent and Marnham.

A. June, July.

T. siliculis subrotundis glanduloso-punctatis campes. superne marginat!s, foliis sagitlatis dentatio tre. on incanis.

T. Pouches roundish: leaves arrout-shaped, toothed, houry.

COMMUN WIIHRADATE MUSTARD. Cornfields, and sumy situations in a clayey soil. Broph-hnll, near Kirnby.

A June.

T. hirsutum, siliculis deltoileo-obcordatis, Bursa folni: radicalibus pmnatifids.

Pastoris.

T. Pouclies compressed, trangularly inversely hearl-shaped, smooth, winumt a border. Root-leaves wing-cleft. 


\section{TETRADYN. SILICULOSA. Cochlearia.}

COMUON SUFPHERD'S PULSE A mong rubish, roalt sides, walls, comfields, graiel-walks, and kilchen garders; very common. southwell ; Nevark.

A. Warch-.-Sept.

COCHLEARIA. Smith.637. With. 57\% Silluta tursida, rugesa, polysperma: valvuins gibbis, ubeuis.

Ponch nothed at the rnd, turgid. rough, many seeded. Valve buiging, blunt.

Armo. C. foliis radiculins oblongis crenatis; caufucza. linis lanceviatis incisis integrisve.

Hont-leaves spear-shaped, scolloped: stemleaves smipt.

Ir) RSE. RA M!S!l. Sirles of ditches, in gariens. Nerwark; Southwel?. L. May.

offici. C. folie radicalibus subrotundis, caulinis obnalis. longis subsinuatis, siliculis glubosis.

C. Root-leaves heart-cercular; stem-leaves ob. long, a luttle indented.

COMMON SCURV Y. RKA AS. Sen shorea, and inland mountains. Not indiencus to this County, though found on Walls, at Kirliby. On Walls, at Wollaton. DEERING.

A. May.

CORONOPUS. Smith. 6go. With. 574. Silicula reniformis, compressa, corrugata, loculis evalvibus, monoupermis.

Pouch kadney-shaped, compressed, wrinkled: cells without valves; 1 seed in each cell.

Ruellii. C. siliculis integris cristato-muricatis, stylo porrecto, corymbis paucifluris.

C. Leaves wing-cleft: stem defressed. 
Cochlearia Coronopus. LINN. 'With.

COMMON WART-CRESS. SWINE'S CFESS. Cornfielt's, rnbbish, road sides; common. Newark; Southrell.

A. June---August.

IBERIS. Smith. 692. With. 575:

Cor. irregularis: petalis duobus exterioribus majoribus. Silacula polysperma, emarginata.

Bloss. uncqual, the two outer petals larger. Pouch roundish, compressed. Partition placed cross-zways; 1 seed in each cell.

I. herbacea, foliis lyrato-sinuatis, caule cen-nudicau. trali nud's simplici; lateralibus foliosis.

lis.

I. Herbaccous: leaves wing.cleft: stem noked, simple.

NAKED-STALKED CANDY-TUFT. Gavelly places, and very barren heaths. In the lane leading to stapleford Moors, from the Sleaford Turnpike; and on a bank by the road side under a Plantation belouging to !oseph Pocklingron, Esq. Nerth Muskham, near Newark; Radford Lings. DEERING. A. May.

\section{SILIQUOSA.}

CARDAMINE. Smith. 695. With 576 . Siliqua elastice dissiliens, valvulis revoluris, dissepimento xequalıbus. Stzgma integrum. Cal. subhians. Glandula utrinque solitari inter stamina breviora et calycem. 
206 TETRADYN. SILIQUOSA. Cardimine.

Pod long 2.edged, opening auth a jerk. Valves rolling vach. parallel to the membranaceous partition. Summit a knob, entire: Calyx rather open.

* Foliis pinnatis.

hirsuta. C. foliis pinnatis exstipulatis : foliolis rotundato oblongis incisis peticlatis.

C. Leaves winged, leafils opposile: stamens 4.

HAIRY LADILS-SHOCK. Cravelly soil. on the driest ban's, as well as in moist filaces, and by the sides of rivulets and springs. Farnsficld Carr.

A. March...June.

praten-C. foliis pinnatis: foliolis radicalibus subrosis. tundis dentats; caulinis lancculatis.

C. Leafits of the root-leaves roundish, those of the stem-leaves spear-shaped: very entire.

MEADOW LADIES-SM MK. CUCKOO FLOWLR. Moist a dedows and pastures. Rewark; ; southwell.

P. April, May.

amara. C. foliis pinnatis : foliolis radicalibus subrotundis; caulinis dentato-angulatis, caule basi radicante.

C. Leaves winged: suckers from the bosom of the leaves: leafus of the siem-leaves angular. sitting.

BITHER-CRFSS. PTTTIR IADIES.SMOCK. Near purls of water, rilulets, and hanks of rivers, ho,ggy places, moiat meaton's and pastures (Bn the Santis of the Circe, wear the Hop (iromnds, Eouthrell. P. April, May. 
SISYMBRIUM. Smith. 700. With. 580.

Siliqua dehiscens valvulis rectiusculis. Cal. patens. Cor. patens.

Pod cylindrical, opening. Valves straightish, about the length of the partition. Caly $\mathrm{x}$ and Bloss. expanding.

S. silnquis declinatis, foliis pinnatts: foliolis Nastur cordato-subrotundis.

lizm.

S. Leaves winged: leafits egg-shaped.

WATER-CR FSS. s, ring;, brooks, aud rivulets. Vewwark: Southwell. P. Sune, July.

S siliquis declinatis, foliis pinnatis, foliolis sylueslanceolat is inciso-serratis.

tre.

S. Podsoblong-egg-shaped, or cylindrical: leafits spear-shaped, serreted.

CRIEPING WATIR-!RCCKRT. Maashy and watery places, and bapks of rivers. Banks of the ditches be. yond the Bridge finm Newark to Kelham; Ldingley Mloors; Farnifieju Carr ; Oxton Stew's.

I. June-.-.Sept.

S. siliquis declinatis pedicellatis, foliis oblon-amphigis pinnatifidis serratisve, petalis calyce lon-bum. gioribus.

S. Pods oblong-egg-shaped: leaves wing-cleft, serrated: petals longer than the cup.

GREATER WATER-ROCKET, Or RADISH. Banks of rivers and ditches. Ditches beyond Newark Bridge, and on the banks of the Trent, near the Meadows.

1'. June--. A ugust.

S. foliis pinnato-decompositis subpilosis, pe-Sophis. talis caly'ce minoribus. 
-08 TETRADYN. SILIQUOSA. Erysimum.

S. Petals smaller than the cups; leaves doubly compound-winged.

FLIX-WEED. Walls, and amongst rubbish, cornfields. Soutbwell; Newark. A. July.

ERYSIMUM. Smith. 706. With. 583 .

Siliqua recta columnaris, exacte tetraedra. Cal. clausus. Sigma capitatum,

Pod straight, strap-shaped, exactly 4-sided. Cal. closed. Summit a knob.

offici: E. siliquis rachi adpressis, foliis runcinatis. nale. E. Pods pressed to the spike.stalk: leaves notched.

COMMON HEDRE MUSTARD. Un!er walls and hedges, road sides, and among rubbisin; very common.

$$
\text { A. Jure, July. }
$$

Barba- E. foliis inferioribus lyratis: lobo terminali rea. rotundato; superioribus obovatis dentatis.

E. Pods indistinctly 4-cornered: leaves lyreshaped, the terminating segment circular.

YELOW ROCKET. BITTER WINTER-CRISS. Walls, banks on the sides of ronning streams, watery places, and sometimes in cultivaterl fields. Ditcher and baiks of the Trent, Newark; Southwell; No:tingham.

P. May-..isugusto

Alliaria. E. foliis cordatis.

E. Leaves heart-shaped:

GARIICK HEDGE-VUSTARD. JACK BY TIIE HEDGE. SAUCE ALONE. IJedges, ditch banks, and shady places: common. Hedge bottoms, in shady lanes and road sides, Newark; Southwell. B. May.

CHEIRANTHUS. Smith. 709. With. 585. 
Germen utrinque denticulo giandulato. Cal. clausus; foliolis duobus basi gibbis. Semi. na plana.

Germen with a glandular tooth on each side. Calyx closed, 2 of its leafits bulging at the base. Seeds flat.

C. foliis lanceolatis acutis subtus canescenti-fruticubus, pubescentia simplicissima adpressa, losus. caule fruticuloso, ramis angulatis.

C. Leaves spear-shaped, acute, smooth: branch. es angular: siem shrub-like.

Chereianthus. Cheiri. Lins. With.

WLD WALS-FLOWER. OId Walls and roofs, On the ruins of the Castle, at Newark, in abuudance; Nottingham Castie.

P. May, June.

ARABIS. Smith. 711: With. 587 .

Glandulcenectariferce quatuor, oblongæ, squamiformes, reflexx. Cal. clausus; foliolis duobus basi gibbis. Stigma simplex. Suliqua linearis, torulosa.

Nectary, glands 4 , within the leafits of the colyx, resembling a reflected scale. Pod long, compressed, strap-shaped, entire aild nobbed at the end.

A. foliis pilosis subdentatis: radicalibus petio- thalialatis, caule ramoso, siliquis adscendentibus. 'na.

A. Slem-leaves spear-shaped, on leaf-stalks, very entire: 10ot-leaves egg-spear-shaped, toothed. 
-10 TETRADYN. SILIQUOSA. Turritis.

COMMON WALL-CRFSS. Walls, roofs, dry sandy banks, and corntields. Quonce Close, at Newark; Banks in the Foot-paths going to Keltam from Newark; Hedges near Mishinam Brilgc, and Thorpe Tollbar. A. April.

TURRITIS. Smith. 715. With. 588.

Siliqua longissima, stricta, sub-angulata. Cal. connivens, erectus. Cor. erecta.

Pod very long, angular, stiff and straight. Calyx close, upright. Bloss. upright.

glabra. T. foliis radicalibus dentatis hispidis; caulinis integerrimis amplexicaulibus.

T. Root-leaves toothed, rough with hair; stem-leaves very entire, embracing the stem, smooth.

SMOOTH TOWER-MUSTARD. Meajows, pastures, pits, and waste places, in a gravelly soil. By the lioad about a mile beyond Blyth, on the left-hand; also in going from Cuckney, as you descend the hill into $\mathrm{W}$ arsop; Fields at Radford and Lenton. DEer In G.

A. May, Jine.

nirsuta. T. foliis omnibus hispidis, caule hirto pilis simplicibus patentibus, siliqua quadrangulari.

T. All the leaves hisped: stem.leaves embrac. ing the stem.

HAIRY TOWER-MUSTARD. Rocks, stony places, old walls, and castles. Rock at Newstead, the seat of Lord Byron; Bulwell Lime Quarries.

P. May.

BRASSICA. Smith. 717. With. 58g. Cal. erectus, subconnivens. Semina globosa. Siliqua teretiuscula; dissepimento promi. nente, subulato, Glandula nectarifer $x$ quafúor. 


\section{TETRADYN. SILIQUOSA. Sinapis. 211}

Calyx upright, close. Glands 1 belween each shorter stamen and the pisitl, and 1 between each pair of longer stamens and the calyx. Seeds globular.

B. radice caulescente fusiformi, foliis lavi- Napus. bus: superiorbus cordato-lanceolatis am. plexicaulibus: inferioribus lyratis dentatis.

B. The root a regular continuation of the stem: spindle-shaped.

RAPF, NAVEW, or COLE-SEFD. On ritch banks, and among corn. Nicwark; Southwell thansficld.

B. May.

B. radice caulescente orbiculari depressa car-Rapa. nosa, foliis radicalibus lyratis scabris caulinis integerrimis lævibus.

B. The root a regular continuation of the stem; round, ciepressed, fleshy.

TURXEP. Fields and gardens; common. B. April.

SINAPIS. Smith. 721. With. 594 .

Cal. patentissimus. Cor. ungues recti. Glandula nectariferce quatuor. Slíqua teretius. cula, dissepimento prominente.

Cal. expanding. Bloss. claws upright. Glands between the shorter stamens and the pistil, and between the longer stamens and the calyx. Pod beaked, opening. Valves shorter than the partition.

S. siliquis multangulis toroso-turgidis rostro arvensis. ancipiti longioribus, foliis ovatis sublyratis.

S. Pods with many angles, swolnand bunched out by the seeds: smooth, longer than the two edged beak. 
212 TETRADYN. SILIQUOSA. Raphanas.

CHAPLOCK. WILD MUSTARD. Cornfiells, and borders of fields. Newark; Sou thwell. A. Miay.

alba. S. siliquis hispidis torosis rostro ancipiti brevioribus, foliis pinnatifidis.

S. Pods rough with hair: beak very lonse, slanting, sword shaped.

WHITE MUSTARD. Connelis, road siles, and in gardens. Newark; Sonthrell; Mansfieid. A. June.

nigra. S. siliquis glabris tetragonis racemo adpressis, foliis summis lineari-lanceolat is integerrimis glabris.

S. Pods smocth, laid flut to the spike-stalk:

COMMOY MUET ARD. Cornfelds, ditch banks. ant road sides. Newark. A. Junc.

RAPHANUS. Smith. 723. With. 596 .

Cal. clausus. Glanáula nectariferce quatuor. Siliqua teres, torosa, subarticulata.

Cal. close, upright. Nect. glands 2 betriecn the shorter stamens and the pistil, and 2. be. tween the longer stamens and the calyx. Pod round, but protuberating, with cells, and. nearly jointed.

Rapha-R. siliquis articulatis lrvibus unilocularibus. mistrum: R. Pods round, jointed, smooth, of 1 cell.

GREAT WHITT. CIIARLOK. WIID RADISH. JOINTED CHARLOCK. Atnongat corn, and borders of fields. Newark. 


\section{Classis XVI. \\ MONADELPHIA.}

Filamenta inferne in unum corpus coalita.

\section{PENTANDRIA.}

\section{Stamina 5 perfecta.}

ERODIUM, Monogynia. Fructus pentacoccus, rostratus; rostra spiralia, introrsum barbata.

ERODIUM. Pistil 1. Fruit beaked, separating into 5 crpsules, each iipped with a long spiral awn. bearded on the inside.

\section{DECANDRIA.}

\section{Stamina 10.}

GERANIUM. Monogyna. Fruit pentacoccus, rostratus : rostra recurva, nuda.

GERANIUM, Pistil 1. Common Receptacle beaked. Caps. 5 dry berries; with a long beak; beaks bent back, naked. 
214 MONADELPHIA. PENTAND. Erodiun,

\title{
POLYANDRIA.
}

\author{
Stamina plurima.
}

- Mistzls many.

MALVA. Polygyna. Cal exterior triphyllus. Caps. verticillatæ, monosperma.

MALVA Outer cup 3 liaves. Sech-coats several; in whols; 1 seed in each.

\section{MONADELPHIA.}

\section{PENTANDRIA.}

ERODIUM. Smith: 727 .

Cal. pertaphyllus. Cor. pentapetala. Glandula nectariferce 5, Fllamenta 5, sterilia. Fructus pentacoccus, rostratus; rostra spiralid introrsum barbata.

Cal. 5-leaved. Pet. 5. Honey glands 5. Barren Filaments 5. Fruit beaked, separaling. into 5 capsules; each tipped with a long. spiral awn bearded inside.

cicutari-E. pednnculis multifloris, foliis pinnatis; um. foliolis pinnatifidis incisis.

E. Flowers in umbels: leafits sitting, wing. clefi, blunt: petals entire. 


\section{MONADELPHIA. DECAND. Geranium: 215}

Geranium cicutarium. Wiıh.

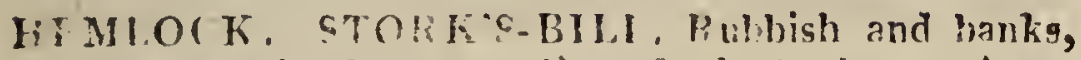
in a sandy soil ; frequent. Larnslield. A, June..-Aug.

\section{DECANDRIA.}

GERANIUM.'Smith. 729. With. 600.

Cal. pentaphyllus. Cor pentanetala. Clandu. la nectariferce 5. Fructus pentacoccus, ro. stratus: rostra recurva, nuda.

Cal, with 5 divisions. Bloss. 5 petals. Pist. 1. Summits 5, common rereptacle beaked. Seeds 5. with a very long twusted tail bent back, naked.

$G$ pedunculis bifloris paniculatis erectis, ca-phaum. lyce subaristato, capsulis carinatis : basi hispidis; apice currugatis.

G. Fruit stalks solitary, 2-flowered, opposite the loaves: caly $x$ somewhat awned: stem upnight: pelals waved.

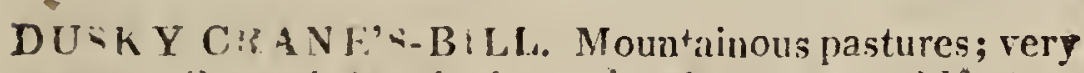
rare. Beyont toutingham, in the way to Alfreton. Rev. G. CraBis.

P. May, Jube.

G. pedunculis bifloris, foliis subseptemparti- pratis inciso-serratis, capsulis undique pilosis, tense. staminus basi deltoidei.

G. Leaf-stalks nearly central; leaves with many divisions, wurinlled; lobes with winged clefts, acute: petals entire. 


\section{MONADELPHIA. DECAND. Geraniur.}

CROWFOOT-IMAVED CRA VE'S-BILL. Misistish meadows and pastures: not uncommon. Aewark. Averhim, and Sonthell Meadows. P. June, July.

roberti-G. pedunculis bifloris, follis subpedatis pinsnum. natifidis quinquangularibus, calycibus decangularibus, capsulis rugosis.

G. Leafits by fives or by threes, lobes wingcleft: calyx with 10 angles.

STIVKINC CRANES-BHET. HERB ROBERT. Walls. hedges, rubbish, and stony placis. Newark; Southwell.

A. May-October.

molle. $G$ pedunculis bifloris alternis oppositifoliis, foliis rotundatis lobatis tomentosis, capsulis corrugatis glabris.

G. Fruit-sialks and foral-leaves alternate: pctals cloven: calyx awnless: stem some. what upright.

DOVE'S-FOOI CRANE'S-BILL. Dry branks, corn. fields, meatowa, and pastures, in a sandy soil. icirark; Southwell. A. Aprii-.-A A ugust.

dissec- G. pedunculis bifloris, petalis emarginatis, tum. foliis quinquepartitis laciniatis, capsulis hirsutis, semmibus reticulatis.

G. Fruit-stulks shorter than the leaves: leaves 5 lobed, lubes 3.cleft or many-clejt: petals notched, seed coats with soji hans.

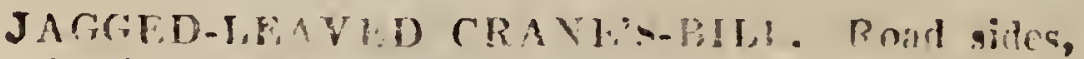
borlers of ficlds, and ditch banks. Rewark; southwell.

A. hiay, June.

colum- G. pedunculis biforis folio triplo longiorihus, brnum. foliis quirquepartitis multifidis, capsulis glabris, semmbus renculatis. 
G. Fruit-stalks longer than the leaves: leaves 5-lobed, lobes many-cleft: calyx 5 siaied: seed-coats smooth.

IONG-STMLRED CRANE'S BILL. Cornfields, pastures, and hedges. Newark; Southwell; Nanstield.

A. June, July.

\section{POLYANDRIA.}

MIALVA. Sinith. 740 . With. 612.

Cal, duplex; cyterior subtriphyllus. Caps. plurimx, monospermx, in orbem disposita. Calyx double, the outer mostly of 3 lcaves. Capsules 8 or more, in a whirl; 1, rarcly 2-celled: 1 seed in each.

M. caule erecto herbacen, foliis septemloba- syluestis acutis, pedunculis petiolisque pilosis. tris.

M. Siem rough: leaves 5 or 7 -lobed, toothed: outer caly'x leafits partly united at the base.

COMmON Midroow. Biedre; foot-paths, and among"st rubisish ; very coininon. Newark; Southwell.

P. Miay - August.

M. caulibus prostratis, follis cordato-orbicu-rotundilatis quinquelobis, pedunculis fructiferis folia. declinatis.

M. Stem prostrate: leaves heart-shaped circular, plaited, 5 or 7 -lobed: fruit-stalks when ripe declinng.

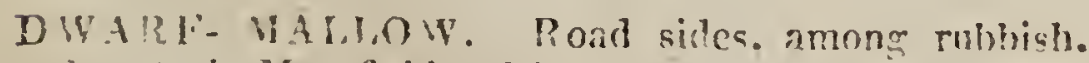
strects in Nitusfield and Solithwell. $\Lambda$. June---sept. 


\section{MONADELPHIA. POLYAND. Malva.}

moscha= M. foliis radicalibus reniformibus incisis; ta. caulinis quinquepartitis pinnato-multifidis, calyce piloso.

M. Stem upright: root-leaves kidney-shaped, cut: stem-leaves with 5 divisions: segments between winged and many-cloven: leafits of the outer cup distinct.

MUSK MALLOW. Meadows, pastures, road sides, and ditch banks; not common. About the Temple, at Kirklington; Farnsfield; Mansfield; in the Foot-way between Oxton and Calverton; and on the Road hetween Retford and Worksop.

P. July, August. 


\section{Classis XVII. DIADELPHIA.}

Filamenta in duo corpora connexa.

\section{HEXANDRIA.}

Stamina 6.

FUMARIA. Cal. diphyllus. Cor. ringens, basi gibbosa nectarifera. Falam. antheris tribus: FUMARIA. Cal. 2 leaves. Bloss. gaping, bul. gine at the bose, and containing honey. Filaments with 3 anthers.

\section{OCTANDRIA.}

Stamina 8 .

POLYGAiA. Cal. lacinix 2 alæermes. Cor. vexillum cylindricum. Legumen obcordatum, biloculare.

POLYGALA. Cal, with 2 segments like wings. Bloss. standard cylindrical. Stamens connected. Caps. inversely heart-shaped, 2-celled.

$\mathrm{U} 2$ 


\section{DECANDRIA.}

Stamina 10.

1 Stamina omnia connexa, seu, monadelpha, tubo superne sæpius fisso.

\section{Stamens all united.}

SPARTIUM. Filam. germini adhærentia. Stigma adnatum, villosum.

SPARTIUM. Filaments adhering to the germen. Summit hairy, growing to the upper side of the style.

GENISTA. Pistillum deprimens carinam, vexillo reflexo.

GENISTA. Pistil pressing down the keel. Summit rolled inwards.

ULEX. Cal. diphyllus. Legumen vix calyce longius.

ULEX. Cup 2 leaves. Legumen hardly longer than the cup.

ANTHYLLIS. Cal. turgidus, legumen includens. ANTHYLLIS. Cup swoln and turgid; inclosing the legumen.

ONONIS. Cal. quinquepartitus. Legumen rhombeum, sessile. Vexillum striatum.

ONONIS. Legumen aiamond-shaped, sitting. Standard scored.

* * Stigma pubescens (necpriorum notæ)

2 Summit downy: filaments 9 united; 1 distinct: 
OROBUS. Stylus linearis, teretiusculus, supra villosus.

OROBUS. Style slender, nearly cylindrical; wool. ly on the upper or inner. side.

LATHYRUS. Stylus supra planus villosusque.

LATHYRUS. Style flat, and woolly above;

VICIA. Siylus sub stigmate barbatus:

VICIA. Style bearded under the Summit.

ERVUM. Sigma capitatum, undique pubescens:

ERVUM. Cup with 5 divisions, nearly equal; and nearly as long as the blossom.

* * Legumen sub-biloculare. (nec priorum nota.)

3 Legumen 2-celled.

ASTRAGALUS. Legumen biloculare, gibbum. ASTRAGALUS. Legumen 2-celled, curved. *** Legumen submonospernum. (nec priorum not $x$.)

4 Legumen with aboul 1 seed:

TRIFOLIUM. Legumen vix calyce longius, 1 sive polyspermum, non dehiscens, deciduum. Flores capitati.

TRIFOLIUM. Legumen longer than the cup; with

1. or two seeds: flowers (mostly') in heads.

* *** Legumen subarticulatum. (nec priorum not $x$.)

5 Legumens almost jounted; sometimes spiral. HEDYSARUM. Legumen articulis monospermis, compressis. Carina obtusissima. 
22 DIADELPHIA. HEXANDRIA. Fumaria.

HEDYSARUM. I egumen with roundish compressed joints. Keel very blunt.

ORNITHOPUS. Legumen articulatum, arcuatum. ORNITHOPUS. Legumen jointed; bent like a bow.

HIPPOCREPIS. Legumen compresso-membranacum, altera sutura pluries emarginatum, curvum.

HIPPOCREPIS. Legumen compressed; membra. naceous; 1 of the seams hollowed out with deep notches.

MEDICAGO. Legumen spirale, compresso-membranaceum. Pistillum carinam deflectens.

MEDICAGO. Legumen spiral; membranaceous: compressed. Pistil pressing down the keel.

****** Legumen uniloculare, polyspermum. (nec priorum notæ.)

6 Legumen 1-celled; many-seeded, (without the mark of the former sub-divisions.)

LOTUS. Legumen teres, farctum. Alce sursum longitudinaliter conniventes:

LOTUS, Legumen cylindrical; filled with cylin. drical seeds,

\section{DIADELPHIA.}

II HEXANDRIA.

FUMARIA. Smith. 748. With. 629. Cal. diphyllus. Cor. ringens. Filamenta duo membranacea, singula antheris tribus. 


\section{DIADELPHIA. OCTANDRIA. Polygula. 233}

Calyx 2-leaved. Bloss gaping. Filaments 2, membranaceous, each supporting 3 anthers. Caps. 1-celled, many-seeded.

F. spicis laxis, siliquis monospermis globosis offici. emarginatis, caule difluso, foliolorum laci- nalis. niis dilatatis.

F. Seed-vessels in bunches, 1 seed in each: stem spreading.

COMMON FUMITORY. Cornfielis, hedge banks, gardens; common. Newark; Southwell.

A. May---August。

\section{$\cdot$ \\ II OCTANDRIA.}

POLYGALA. Smith. 752. With. 622.

Cal. pentaphyllus: foliolis duobus maximis, alaformibus, coloratis. Legumen obcordatum, biloculare.

Calj $\times$ 5-leaved, 2 larger wing-like, before the ripening of the seeds, coloured. Caps. inversely heart-shaped, 2-eelled. Seeds solitary.

P. floribus cristatis racemosis, caulibus herba- vulgaceis simplicibus procumbentibus, foliis line- ris. ari-lanceolatis.

P. Flozwers in bunches: stems herbaceous, simple, trailing: leaves strap-spear-shaped.

MILKWORT. Pastures and heaths; not uncommon. Newark; Southwell.

I. June, July, 
224 DIADELPHA. DECANDRLA. Spartium.

\section{DECANDRIA.}

SPARTIUM. Smith. 753. With.6z3.

Stigma longitudinale, supra villosum. Filamenta monadelpha, germini adhærentia. Cal. deorsum productus.

Cal. extending downwards; 2-lipped. Fila. ments adhering 10 the germen. Summit woolly above.

scopari. S foliis ternatis solitarisque, ramis incrmium. bus angulatis.

S. Leaves in threes, and solitary: branches without prickles, angular.

- common BRGOM. Dry pastures, and road sirles in a samly snil. In the Road between lietford and Worksop, plemtifully.

S. May, June.

GENISTA. Sinith. 754. Wh/h. 624.

Cal. bilabiatus; labio superiore bidentato, inferiore tridentato. Vexillum oblongum, a pistillo staminibusque deorsum reflexum.

Calyx 2-lipped, the upper 2, the lower 3-toothed. Standard oblong, bent back from the stamens and pistil. Legumen regular shaped.

sincto- G. foliis lanceolatis glabris, ramis teretibus ria. striatis erectis inermibus.

- G. Branches scored; cylindrical, upright: leaves spear-shaped, smooth: legumen cylindrical.

DYER'S GREEN-WEFD. WOOD WAXEN. PaStures, and borders of coinfields; frequent.

S. July---August. 
DIADELPHIA. DECANDRIA. Ulex. 225

$\mathrm{G}$ spinis simplicibus, ramis floriferis inermi-anglica, bus, fuliis ovato-lancenlatis.

G. Very thorny; smooth: thorns simple and compound: leaves spear-shuped.

NERDLE CIRES-WEED. PETTY-WIIN. fieaths, and noist sporfgy ground. Edingley, Staplefork, and Langford Hoors. S. Niay, June.

ULEX. Smith. 756 . With. 626 .

Cal. diphyllus. Legumen vix calyce longius. Stam. omnia connexa.

Calyx 2-leaved. Legumen scarcely longer than the calyx.

$\mathrm{U}$. dentibus calycinis obsoletis conniventibus, bracteis ovatis laxis, ramulis erectis.

U. Teeth of the calyx indistinct, converging: floral leaves egg-shaped, loose: branches upright.

COYMON FUPZE. WHIN or GORZF. Heath, road sides, and pastures; very common. S. Feh-A $\mathrm{kg}$ -

U. dentibus calycinis lanceolatis distantibus, nanus. bracteis minutis adpressis, ramulis decumbentibus.

U. Teeth of the calyx spear-shaped, distant: floral-leaves small, pressed to the calyx: branches expanding.

U. curopæus. Var. 2. With.

DIV $\triangle R F-E U I Z Z$. Heathe, roid siles; not very common. Beyond Polter's Hill, in closes near Thurliy Noors.

S. August---Ociober.

ONONIS. Smith. 758. With.627.

Cal. quinquepartitus; laciniis linearibus. Vexillum striatum. Legumen turgidum,

euro. paus. 
226 DIADELPHIA. DECANDRIA. Anthyllis.

rhombeum, sessile. Filamenta monodelpha absque fissura.

Cal. with 5 divisions; segments strap-shaped. Standard scored. Filaments united without an opening. Segments swoln, sitting, simple, of 1 cell.

arvensis. $\mathrm{O}$. caule villoso, ramulis demum spinescentibus, floribus subsolitariis, foliis subsim. plicibus postice integerrimis.

O. Flowers in bunches, 2 together; leaves 3 together, the upper ones solitary: branches. without thorns, somewhat woolly.

A. $O$ inermis. IIudson. O. arvensis. With. HAIRY REST-HARROW. Light sandy soil; not common. Blidworth.

P. June.

B: O. spinusa. LINN. With.

THORNY REST-HARROW. CAMMOCK. Barren pastures, and liedge banks, in a sandy or marly soil ;. conmon. Soutbwell; Halam Hill. P. June---Aug.

ANTHYLLIS. Smith. 759. With. 629. Cal. ventricosus. I.egumen subrotundum, calyce tectum. Stamina monadelpha.

Calyx bellying. Legumen roundish, covered. vulnera-A. herbacea, foliis pinnatis inæqualibus, caria. pitulo duplicato.

A. Herbaceous: leaves winged, unequal: flowers in a double head.

KIDNE:-VFT(H I.AIIFS-FINGER. Meadows and pasturcs, in a dialky or calcareous soil. Newark and Averhan Nhatows; Oxton Hill; Kirkby; Butwell; aud abcul Banlewond Farm, in the Spring close, on the sifle of ismetiwood hill; near Thorney moor hol, at Southwell.

P. June--Aurust. 
DIADELPHIA: DECANDRIA. Orobus. 227

OROBUS. Smith. 761. With. 630.

Stylus linearis, teretiusculus, supra villosus. Cal. basi obtusus; laciniis superioribus profundioribus, brevioribus.

Calyx blunt at the base; the 2 upper teeth shorter, but more deeply divided. Style threadshaped.

O. foliis pinnatis elliptico-lanceolatis, stipu-tuberolis semifagittatis basi dentatis, caule simpli- sus. ci.

O. Leaves winged, spear-shaped: stipula halfarrow.shaped, very entire: stem simple.

COMMON OROBUS. HEATH PEA. Moist heath, and woody sifuations; not common. Thickets near Oxton Tollbar; Lperstone Wood; Mirs Tottie's Wood; Warnham Wood, near Kneesall.

P. May, Jnne.

LATHYRUS. Smith. 763 . With. 631.

Stylus planus, supra villosus, superne latior. Cal. laciniæ superiores duæ breviores.

Cal: 2 upper segments shorter. Style flat, broader upwards; woolly on the upper sur. face. Legumen generally equal, broad.

* Pedunculis unifloris.

1 Fruit-stalks 1 flowered.

L. pedunculis subunifloris, foliis simplicibus, Nissostipulis subulatis.

L. Leaves simple: stipula awl-shaped.

CRIMSON LATHYRUS, or GRASS-VETCH. Borlers of cornfields and pastures; rare. On the sides of the Corniclds on Beacon illl, Newark. $\Lambda$. May. 
* Peduncilis multifloris.

2 Fruzl-stallis many-flowered.

praten- L. peciunculis multifloris, cirbis diphyllis subsis. semplicibus : foliolis lanceolatis.

L. Tendrals with 2 leaves, quite simple: leafits spear. shaped.

TMHOW LATHYRUE, MTADOW VETCHLING. Bleatows, pastures, noosits, thickets, and hedges. Rewark; southweil, Proly, August.

sylues. L. pedunculis multifloric, cimhis diphyllis: tris. foliolis ensifomibus, cante alato.

L. Tendrils with 2 lacies : leafuts sword-shaped: stem with membranaceous border's between the knots.

NARROW-LPATED IATMYRUS, or I:VERLASTING PHA, Wnnls and hedres; not common. In the Jed ing through the 'Julbar on Denrton llill. between Kelham and Caunton: Pr. Buck. Pales of Culwich ?ark. hr. BRUnion. P. July, August.

VICIA. Smith 768. With. 63.5 .

Stigma latere inferiori transverse barbatum.

Summit bearded across underneath. Legumen generally with knot.like proluberances.

* Pedunculis elongatis, mulinforis.

1 Fruit-stalks long; many flowered.

syluati. V. pedunculis multifloris, foliolis ellipticis, ca. stipulis lunat is dentatis.

V. Leafits oud: stipnla finely loothed.

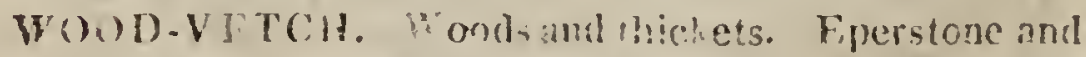
Flunt am if nols; Nimier Corce, in lhe parish of Eahring, muler a birge Uish. P. Jul;, Aug. 
V. pedunculis multifloris, floribus imbricatis, Cracca. foliolis lanceolatis pubescentibus, stipulis semisagittatis subintegris.

V.' Flowers tiled: leafis spear-shaped, pubescent: stipulae entire.

TUF THD Y:TCH. IERgea, shary place, meadows, ficlds and willow bets; co.nmon. On the hanks of the Trent ditches, and in the mealows, at Nesvark and Southwell. P. July, hugust.

* Floribus axillaribus subsessilibus.

2. Flowers 2 or more logether, nearly siting.

V. legunninibus sessilibus subbinat is erectius- sativa:

culis, folitis inferioribus retusis, stipulis dentatis nutatis, seminibus lævibus.

V. Legumens mostly in pairs, upright: leafits inversely spear-shaped, blunt, nothed: sizpulce loothed: seeds compressea'.

COMUON VETh H: Dry meadows, pastures. and cornfields. Newarh; sounlw. $11 . \quad \Lambda$. May, Jume.

V. leguminibus pedicellat is subquaternis e- sepium. recus glabris, foliolis ovatis obtusis : exterioribus minoribas.

$V$. Legumens mostly it together, upright: leafits egg.shiped, viery entzre, the outer ones gradually sinaller.

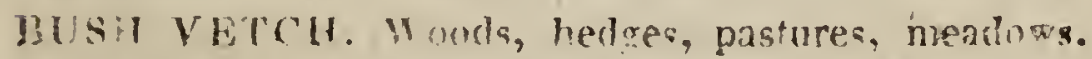
hewark; Sonthwell; Manotield P. Mros, Jube

ERVUM. Smith. 775. With. 639.

Sigma capitatum, undique pubescens.

Caly $\mathrm{x}$ with 5 divisions, as lor.g as the blossoms. 


\section{DIADELPHIA. DECANDRIA. Ornithopus.}

tetras- E. pedunculis bifloris, leguminibus glabris permum. pulyspermis.

E. Fruit.sialks mosily 2 flowered; seeds a, glo. bular.

SMOOTH TARE. Corn-fields, hedgea, and borders of plenghed fields. Edingley Hill ; Eperstone; Xewark; Southwell.

- hirsutum. E pedunculis multifloris, leguminibus hirsutis dispermis.

E. Fruit-stalks many-flowered: seeds 2, globular.

HAIRY TARE. Sandy corn-fields and mealows. Newark. Southwell. Edingley Lill. S perstove. A. June.

ORNITHOPUS. Simith. 776. With. 640 . Legumen articulatum, tcres, arcuatum. Seed.vess. cylindrucal, but jointed and crooked. perpuszl. O. follis pinnatis, legumnibus incurvis.

lus. O. Leaves zinged: legumens bozred in, muck larger thun the wingea flower-scule.

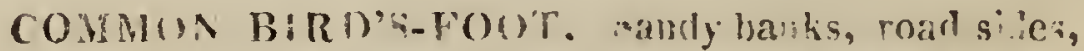
leaths and pastures; very frcqueut. Newarts; inttincham Park.

A. May.

HIPPOCREPIS. Smith. 777. With.641. Lrgumen articulatum, comrressum. altesa su. tard pluies enorgmatum, curvum.

Seed veseel mam-celled, compressed, crooked, with sezeral hutches along one of the seams.

comosa. H. leguminibus pedunculat is confertis arcuals margine exceriore repandis. 


\section{DIADELPIIA. DECANDRIA. Hedysarum. $2 z 1$}

H. Legumens on fruit-stalks, crowded, bowed, serpentze.

TUFRED HoRGE:SHOE VETCH. Mearlows and photure; in a calcarenss soil ; rare. In Notingham Park, hu no very common. DEkRING. A diligent and repeitcd, though fruinless, search has heen marle in Fotlingham frark for this phat, which I hive not been able to tind in Notringhamahire, In the neighbouring combly of lincolu it grows very abundantly, with many other rare species, upon Ancaster Heath.

P. May---. August.

HEDYSARUM. Smilh. 778. With. 642 . Legumen articulis monospermis. Cor. carina transverse obtusa.

Keel broad and blunt on the outer part. Legumen jointed, 1 seed in each joint.

$\mathrm{H}$. follis pinnatis, leguminibus monospermis Onobryaculeatis, corollarum alis longitudine ca- chis. lyces, caule elongato.

H. Leaves winged: legumens with I seed, - prickly: wings as long as the calyx: stem growing long.

SAIN'T-FOIN. Meadows and pastures, particularly in a chalky soil. Beacon Hill Ficlds, Newark.

P. June, July.

ASTRAGALUS. Smith: 779. With。642。

Legumen biloculare gibbum.

Cans. generally 2-celied; bulging: the solitary filaments cylindrical.

A. caulescens prostratus, leguminibus subtri- glyciquetris arcuatis, foliis pedunculo longiori-phyllos. bus: foliolis ovatis. 
A. Stems prostrale: legumens nearly 3 cornered', bent like a bow: leuves longer than the fruit-stalks: leafits oval.

SWEET MILK-VETCII. Meadows, pastures, and ditch banks, especially in a calcireous snil. Hedge beinhs hetween Vewark and Hawton; between the id Mile Post and Thorpe-rune Tollbar; and in the hedges going up the hill into Stoke, from the Tollbar. P.June.

TRIFOLIUM. Smith. 781 . With. 645 .

Flores subcapitati. Legumen vix calyce longius, non dehiscens, deciduum.

Elowers moslly forming a head. Capsule or Legumen scarcely longer than the calyx; not opening, but falling off entire.

* Meliloti. Leguminibus nudis polyspermis.

1 Melilots. Capsules naked, 1-celled, containing several seeds.

affici- T. leguminibus racemosis nudis dispermis runale. gosis acutis, caule erecio.

T. Capsules in bunches, often 2-seeded, wrinkled, acute: stem upright.

T. Melilotus-officinalis. LINN. Wiik.

COMMON MELILOT. Cornfields, meatows, and ditch banks, in clajey soil ; Newark; Sombwell.

A. June, iuly.

* Lotoidea. Leguminibus tectis polysper. mis.

2 Legumens covered; many-seeded.

repens. T. capitulis umbellaribus, leguminibus tetraspermis, caule repente.

T. Iteads like umbels: legumens 4-seeded: stem creeping. 


\section{DIADELPHIA. DECANDRIA. Trifolum 233}

WHITE TREFOIL. DUTCH CLOVER. Mé. dows and pastures. Newark; Southwell.

* * Lagopoda. Calycibus sapius villosis.

3. Calyxes woolly.

T. capitulis villosis subquadrifloris, involu-subtercro centrali reflexo rigido stellato fructum raneum. obvolvente.

T. Ueads woolly; 5 flowered; a rigid tuft from the contre reflected upon, and inclosing the fruit.

SUBTERI:ANEOUS TREFOII. Barren heathsand pastures, in sandy or gravelly soil. Quonce Hil! Close, Newark; Langlord; Slerwood liorest. A. Riuy.

T. spicis densis, caulibus adscenrentibus, praiense. corollis inaqualibus, dentibus calycinis quatuor $x$ qualibus, stipulis aristatis.

T. Spikes crounded: blossoms unequal: calyx with 4 of the leeth equal: stipula auned: siems ascending.

COHMON PUEPSE, TPECOIL, or CLOVRR.

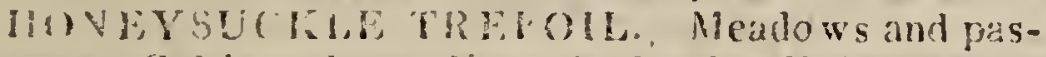
t:res. Cultivated near Newark, Southwell, Mansfeld, Dottinghistin.

P. Nay--.Sept.

T. spicis laxis, caulibus flexuosis ramosis, medizm. corollis subxqualibus, stipulis subulatolinearibus.

T. Spikes loose; blussoin nearly regular; sii. pula awl-shaped, converging; stems. zig. zag, branched.

ZIG.ZAG TREFOIL. In high cicareous soils; not. uncominen. Llalam Hill; soubwell. P. July.

T. spicis vilios ssimis subcylindraceis, denti-aruense bus calycinis setaceis corolia longioribus, 
fuliolis obovato-linearibus.

T. Spikes woolly, oval: teeth of the calyx brise. tle-shaped, woolly, equal.

II ARES-FOOT TRFFoif. Sandy pistures and corn-fields. sides of the hills in the $\mathbf{Q}$ wace Cluse; sandy pastures towards fawtois; in a mursery of mise at Balderton, frequent; Fansield; Blidworth

A. July, August.

**** Lupulina. Vexillis corolla reflexis, demum scariosis:

4. Hop Trefoils. Standara of the bloss. bint inwards permanent.

procum- $T$. spicis ovalibus imbricatis, vexillis deflex-

bens. is persistentibus sulcatis, caulibus procumbentibus, foliolis obovatis.

T. Spikes oval, closely tiled, many-flowered: siems wide spreading.

HOP TREFOH. Dry meadors and pistures: sanily. ground by road sides. sewark ;" South well ; Mansfield.

A. Junc, Juty.

LOTUS., Smith. 793. With. 656 .

Iegumen cylindricum, strictum. Ala sursum Jongitudinaliter coniventes. Cal. tubulosus.

Calyx tubular. Wings converging lengthways, and upwards. Legumens straight, generally with cells.

cornicu-L. capitulis depressis muliforis, caulibuslatus decumbentibus, leguminibus teretibus patentibus.

L. Head's of the flowers flatted at the top: stems herbaceous, trailing: legumens cylin. dirical, expanding:

CONMON B!RD'S-FOOT TREFOIL: Meadows, justues, heatha, wat toud siges: very conmon.

P. Jure-.-A Augustin 
DIADELPHA. DECANDRIA. Medicago. 235

MEDICAGO. Smit. 795. With. 6,53.

Legumen compressum, cocilleatum, carinam corolla a vexillo deflectens.

Pictil bent, pressing down the keel and springing out of it with ia jerk. S. vess. a legumin, compressed, bent, or twisted spirally.

M. Peduncuits racemosis, leguminibus con-sativä. tortis, caule erecto glabro.

M. Flowers in bunches: legumens narrow, regular, twisted: stem upright, smouth.

LUCERNE. PURPLE MHDHER. Neadows, pastures, and ditch bauks, culivatel at Vonark Mansfield; Hovering!um.

P. June, July.

M. spicis oratis, leguminibus reniformibus lupuline: venaso-corrugatis monospermis, caule pro. cumbente.

M. Spikes oval: S. vessels kidney-shaped, with 1 cell, and 1 seed: stems tranling.

BLACK MEDICK, or NOYSUCH, Cornfields, meadóws, and pastures. Newark; Southwell.

A. May---August.

M. leguminibus cochleatis, stipulis subdenta- poly. tis, caule diffuso.

M. Fruit-stalks with 2 or 3 seed-ressels: legumens prichly: stipula tooihed: leafits inverseley heart-shapid: stems spreading

A. M. polymorpha arabica. LiNN. M. arabica. With.

IEART MEDICK, or CLAVER. Dry sandy pas. tures, borders of fields. On a bank by the foot closes between Newark and Kelham; on the outsile of the Giurch-yard at Averham.

S. May, Jyne. 


\section{Classis XVIII. POLYADELPHIA.}

Filamenta in tria, vel plura, corpora connexa.

\section{POLYANDRIA.}

Stamina numerosa.

HYPERICUM. Cal. quinquepartitus, inferus. Petula 5. Filamenta in 3 vel 5 phalanges basi connata. Capsula polysperma.

HYPERICUM. Cal. with 5 divisions beneath. Bloss. 5 petals. Styles 1, 3 or 5 . Capsules 4 3 to 5 celled.

\section{POLYANDRIA.}

HYPERICUM. Smith. 800. With. 663.

Cal. quinquepartitus, inferus: Petala 5: Fulamenia multa, in 3 rel 5 phalanges basi conna:a. Capsula polysperma.

Cal. with 5 divisions. Petals 5 . Filaments nu. merous, urited at the base into 3 or 5 sets. Capsule with 3 or 5 cells, and many seeds. 
H. floribus trigynis, caule quadrangulo her-quadranbaceo, foliis pellucido-punctatis, foliolis gulum. calycinis lancecolatis.

H. Leaves egg-shaped, with pellicia' dots: stem 4 -cornered.

SRUARE ST. IOHN'S WORT. ST. PETER'S' WORT. Moist hedges and shady places. Boggy groued in the Quonce Close, iewark; Oxton Stews ; Edingley Mours. P. July, August.

H. floribus trigynis, caule ancipiti, foliis ob-perforco. tusis pellucido-punctatis, foliolis calycinis tum. lanc eolatis.

H. Stem 2-edged: leaves blunt; with pellucid dots.

PEREORATAD ST. JOIN'g wort, Thichel, woods, hedges, dry barks, Barnby lane. Newart: south: ell.

P. July, August.

I. floribus trigynis subcymosis, caule anci-humifupiti prostrato, foliis ellipticis glabris. sum.

H. 'Flowers auxillary, solitary: stems z-edyed, prostrate, thread-shaped: leaves smooth.

TRAHING ST. JOHN'S WORT. Meadows, pastures, leaths. Ditch banks abont Coddington, and in the lane leading to the Moors of stapleford and Lingford; lidingley Mnor; Oxton Stous; Ratley, adjoining Thurgaton Bounciary.

H. floribus trigynis, calycibus serrato glandu- hirswlosis, caule erecto tereti, folis ovatis pube- tum. scentibus.

H. Calyx serrated with gland's: stems cylin. drical, upright: leaves egg-shaped, some. what downy. 
238 POLYADEL. POLYAND. Hypericum.

HAIRY ST. JOIIN'S WORT. Thickets, hedges, and woods Thickets near Oxton Tollbur; Enerstone and Oxton Woods; Westhorpe Dumble, near southwell. P. June, July.

pul- H. foribus trigynis, calycibus scrrato-glan= chrum. dulosis, caule tereti, foliis amplexicaulibus cordatis glabris.

H. Cal;'x serrated with glands: stem cylindri. cal: leaves embracing the stem, hicarl-sha. ped, smooth.

SHALI, UPRIGHT ST. JOHN'S WORT. Hedges, and heiths, in expoced sunny situations. Westhorice Dumble, near Southwell; stapleford and Langford Monrs; Bamby Lune, anongat gorze bushes; thit

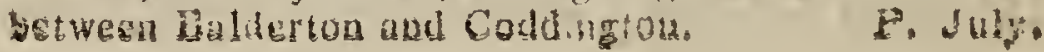

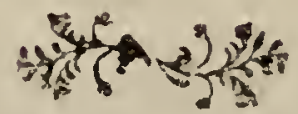




\section{Classis XIX. \\ SYNGENESLA.}

Antherx in tubum connatx. Flores com. positi.

\section{POLYGAMIA RQUALIS.}

Flosculi omnes hermaphroditici, fertiles.

* Semiflosculosi Tournefortii; corollulis ligulatis omnibus.

1. All the Florets strap-shaped.

HYPOCH ERIS. Receplaculum paleaceum. Pappus plumosus. Cal. subimulicatus.

HYPOCH ÆRIS. Receptacle chaffy. Duwn somewhat feathered. Cal. tiled.

CICHORiUm. Recep'. subraleaceum. Pappus palcaceus, semine brevior. Cal. calyculatus.

CICHORIUM. Rereplacle somerohat chuffr. Down chaff like. Cal double.

CREPIS. Recept, hispidiusculum., Pappus sim. plex, substiparatus. ral. calyculatus, squamis decirtus, demum torulosus.

CREPIS. Recepracle naked. Duwn hair-like. Cal. doulle, with scales of different shapes. 
HIERACIUM. Recept, nudiusculum, punctatum. Pappus simplex, sestilis. Cal.imbricatus, oratus:

HIERACIUM. Receptacle naked. Down hairlike; siting. Cal. tiled; egg.shaped.

HEDYPNOIS. Rerete nodum, punctatum. Papfus plumosus, sessilis, inzqualis. Cal. imbricatus, calyculatus.

TEDYPNOIS. Recepracle natid, dolled. Down Jeathered, sitting, unequal. Cal. talcd, double.

PICRIS. Recept. nudun Pappus plumosus. Semna iransversim sulcar Cal. duplicatus; interior xqualis; exterior iaxus.

PICRIS. Receptacie naked. Duwn feathered; on a pedicle. Cal double.

TRAGO'DGON. Rerepi. nudum. Pappus sipitatus, plumosus. Cal. simplex, polyptyllus.

TRAGOPOGON. Beceptacle nuked. Diwn feathered; on a pedicie. Cal. simple.

LEONTODON. Rerept. nudum. Papus stipitatus, simplex. Cal inbricalus, sqamis lasiusca. lis.

LEONTODON. Receptacle naked. Down on a pedicle Collonted; scules flexable.

LACTUCA. Recept. nudum. Pappus sipitatus, simplex. Cal. imbricatus, cylindiaceus, margme membranaceo.

I ACTUCA. Recepacle nuked. Down hair-like; on a pedicle. Cdi. nulea; scales stimny at the edges. PRENAN1 HES. Recept. nuinm .Pappus sub. 
\$YNGENESIA. FOLYGAM. BQUALIS. 24

sessilis, simplex. Cal. calyculatus. Flosculi sim. plici serie.

PRENANTHES. Receptacle naked. Down hairlike. Cal, double; containing about 5 florets.

SONCHUS. Recept. nudum. Pappus sessilis, simplex. Cal. imbricatus, ventricosus.

SONCHUS. Receplacle naked. Down hair-like; sitting. Cal. tiled; bellying (at the base.)

LAPSANA: Recept. nudum. Pappus nullus. Cal. calyculatus; foliolis interioribus zequalibus, canaliculatis.

I.APSANA. Receptacle naked. Down none. Cal. double.

* Capitati. Corollu!æ omnes tubulos $x$, apice divaricato-putulæ.

2 Fiowers in globular heads,

CARLINA Cal. ventricosus; squamis exterioribus spinosis ; interioribus coloratus scariosis radiantibus. Recept. palaceum. Pappus plumosus.

CARLINA. Cal. radiate. Rays coloured.

ARCTIUM. Cal. globosus; squamis apice hamatis inflexis.

ARCTIUM. Cal. scales bent inwards at the points, and hooked.

CARDUUS. Cal. ventricosus; imbricatus; squamis spinosis. Recept. pilosun. Pappus deciduus.

CARDUUS. Cdl. with thorny scales; bellying. Recept, hairy.

ONOPORDUM. Cal. ventricosus; squamis pa- 
242 SYNGENESIA. POLYGAM. SUPERFLUA.

tentibus, spinosis. Recept. favosum, subpalcaceum ONOPORDUM. Cal. with thorny scales: bellying. Recept. like a honey-comb.

SERRATULA. Cal. subcylindricus, imbricatus; squamis inermibus. Pappus persistens.

SERRATULA. C.al. nearly cylindrical; tiled: scales rather acute, but not thorn-like.

* * Discoidei. Corollulx omnes tubulosæ, erec. to paraileli, apice planiusculi, densi.

\section{Florets all tubular.}

EUPATORIUM. Recept. nudum. Pappus scaber. Cal. imbricatus, oblongus. Stylus semibifidus, exsertus.

EUPATORIUM. Recept. naked. Down feathered. Cal. tiled. Pistil very long.

BIDENS. Recept paleaceum. Pappus retrorsum scaber. Cal. polyphyllus: Cor. subinde radiata.

BIDENS. Recept. chaffy. Duwn awn-like. Cal. izled.

\section{POLYGAMIA SUPERFLUA.}

Flosculi disci hermaphroditici; radii frminii ; omnes fertiles.

* Discoidei. Corollulæ radii obsoleta.

1 Flirets all tutular.

TANACETUM. Recept nuduns. Sem. coronata. Cal imbricatus, hemispharicus. Flosc, radii trifidi, obsoleti, interdum nulli 
SYNGENES. POLYGA.M. SUPERFLUA. 243

TANACETUM. Recept. naked. Down only a sort of border. Bloss. of the circumference 3 cleft. CONYZA. Recept. nudum. Pappus scaber. Cal. imbricatus, subrotundus. Flosc. radii trifidi.

CONYZA. Recept.naked. Down hair-like. Bloss. of the circumference 3 -cleft.

GNAPHALIUM. Recept. nudum. Pappus scaber aut plumosus. Cal. imbricatus squamis scariosis culoratis. Flosc. radii subulati.

GNAPHALIUM. Recept. naked. Down feathered, or hair-like. Cal. with skinny concave scales.

ARTEMISIA. Reccpt nudum, aut villosum. Pappus nullus. Cal. imbricatus squamis rotundatis conniventibus. Flosc. radii subulati, integerrimi. ARTEMISIA. Recept. almost naked. Dawn none. Florets in the circumference, without a petal.

* * Radiati. Corollulæ radii ligulatæ.

2 Flowers radiale.

BELLIS. Recept. nudum, conicum. Pappus nulJus. Cal. hemisphæricus, squamis æqualibus. Sem. obovata.

BELLIS. Recept. naked" Down none. Cal. simple, with equal scales.

MATRICARIA. Recept. nudum, cylindraceoconicum. Pappus nullus. Cal. planiusculus, im. bricatus, squamis margine scariosis.

MATRICARIA. Recept. naked. Down none. Cal. tiled; scales acute. 
244 SYNGENES. POLYGAM. SUPERFLUA.

ChRYSANTHemuM. Recept. nudum. Pappus nullus. Cal. hemisphæricus, imbricatus, squamis margine dilatatis, membranaceis.

CHRYSANTHEMUM. Recept. naked. Duwn none. Cal. the inner scales membranaceous.

PYRETHRUM. Recept. nudum. Pappus marginatus. Cal. hemisphæricus, imbricatus, squanis margine dilatatis, membranaceis.

PYRETHRUM. Recept. naked. Seeds crowned with a membranaceous margin. Cal. hemispherccal, imbricated with sharpish scales, bordered with a membrane.

INULA. Recepi. nudum. Pappus simplex. Cal. imbricatus. Cor. radii numerusissima, lineares. Antherce basi bisetæ.

INULA. Recept. naked. Down hair-like. Anthers with 2 bristles at the base.

ERigeron. Recepl. nudum. Pappus simplex. Cal. imbricatus. Cor. radii lineares, angustissima numerosa.

ERIGERON. Recept. naked. Down hair-like. Bloss. in the circumference very slender.

SOLIDAGO. Recept. nudum, scrobiculatum. Pappus simplex. Cal. imbricatus, squamis conniventibus. Flosc, radii circiter 5 .

SOLIDAGO Recept. naked. Down hair-like. Bloss. of the circumference about 6 ; remote.

SENECIO. Recept, nudum. Pappus simplex: Cal. cylindricus, polyphyllus, $x$ qualis, calyculásus, squamis apice sphacelatis. 
SYNGENES. POLYGAM. FQUALIS. $\$ 45$

SENECIO. Recept. nalied. Down hair-like. Cul. with the scales dead at the ends.

TUSSILAGO. Recept. nudum. Pappus simplex. Cal. simplex, polyphyllus, xqualis, submembranaceus, basi ventricosus.

TUSSILAGO. Recept. naked. Down hair-like. Cal. scales somezuhat membranaceous.

ANTHEMIS: Recept. paleaceum. Pappus submarginatus. Cal. hemisphæricus; squamis suhæqualibas. Flosc. radii plures quam 5, ublongi.

ANTHEMIS. Recept. chaffy. Dow none. Cal. hemispherical.:

ACHILLEA. Recept. paleaceum. Pappus nullus. Cal. ovatus, imbricatus, inæqualis. Flosc. radii 5 ad 10; ubcordato-subrotundi.

ACHILLEA. Recept. chaffy. Down none. Cal. oblong, strap-shaped. Florets about 5.

\section{POLYGAMIA FRUSTRANEA.}

Flosculi disci hermaphroditici ; radii neutri, steriles.

CEnTaUrea. Kecept. setosum. Pappus sim. plex. Cor, radii infundibaliformes, longiores, irregula:es.

CENTAUREA. Recept. bristly. Down hair-like. Bloss. of the circumference tubular. 
246 SYNGEN. POLYG. ÆQUAL. Tragopogon. XIX SYNGENESIA.

\section{POLYGAMIA ÆQUALIS.}

Semiflosculosi. Flosculi ligulati.

TRAGOPOGON. Smith. 812. With 672 . Recéptaculum nudum. Cal. simplex, polyphyllus. Pappus stipitatus, plumosus.

Receptacle naked. Calyx simple. Down feathered.

pralen-T. calycibus corollarum radium subzquanse. tibus, foliis integris carinatis acuminatis; basi dilatatis, pedunculo tereti.

T. Calyx as long as the rays of the blossom: leaves entire, quite straight: fruit-stalk cylindracal.

YELLO if-GOAT'S-BEARD. Meadows and pastures. Newark, and A verham Meadows, plentifully ; Southwell ; Nansfie!d ; and Notingham.

B. Juue.

PICRIS. Smith. 814; With. 673.

Recept. nudum. Cal. duplicatus; interior xqualis; exterior laxus. Pappus plumosus. Semina transversim sulcata.

Receptacie naked. Calyx double. Down fea. thered. Seeds wuth transvere furrozos.

echioides. P. calyce exteriori pentaphyllo maximo aculeato, pappo stipicato, foliis repandis.

P. Outer calyx of 5 leaves, larger than-the inner; the inner awned.

Bititly uX-IONGUE. Porders of fields. Iledge. banks br the roat, and on the borlers of cornticlds on Jeacon iill, Newark; Southell. A. June, July. 
SYNGEN. POLYG. EULIS. Sonchus. 247

SONCHUS. Simith. 815. With. 674.

Kecept. nudum Cal. imiricatus, ventricosus. Pappus simplex, sessilis.

Recept. naked. Calyx tiled, bellying. Down hair-lise.

S. pedunculis calycibusque hispidis subum- palus. bellatis, foliis runcinatis basi sagittatis tris. margine scabris.

S. Fruit-stalks and calyxes rough with hair, in a sort of umbel: leaves notched, arrowshaped at the base.

TALL MARSII SOW-THISTLE, Watery places, and banks of rivers; not common. Daingley Moor.

P. July, August.

S. pedunculis calycibusque hispidis subum- arvenbeliatis, foliis runcinatis denticulatis basi s2s. cordatis, radice repente.

S. Fruit-stalks and calyxes rough with hair, in a sorl of umbel: leaves notched, heart-shaped at the base.

CORN SI)W-THISTLE. Cornfields and di ch banks. On Beacon Hill, Newark. P. August.

S. pedunculis tomentosis, calycibus lævibus olera. foliis runcinatis dentatis.

ceus.

S. Fruit-stalks cottony: calyxes smooth.

CONMON SOW-TIISS ILLE. Cultivated ground, especially in a rich soil, dung-hills, and hedge; ; very common.

A. July-.-sejtember.

LACTUCA. Sinith. 819. With. 676.

Recept. nudum. Cal. imbricatus, cylin!ra. ceus, margine membranaceo. Pappus.sin. plex, stipitatus. 
$2_{4}:$ SYNGEN. POLYG. EQUALIS. Prenanthes.

Recepracle noked. Calyx tiled, cylindrical, the scales membranaceous at the edge. Duwn hair.like, on a pedicle.

virosa. L. foliis horizontalibus denticulatis carina aculeat is.

L. All the leaves horizonlal, toothed; their. mid-rib prichly on the back.

STRGNG-SCEYTED LNTUCE. Ditch hanks, bovers of fields. In at he ige near the Greet bridge, Southwell; on a bonk helwcen Codldington and the Shire: Ditch, toward Peckingham; hy the sicle of the road from Blyth to Bawtry. B. A ugust, Sentember.

saligna. L. foliis hastato-linearibus pinnatifidisque sessilibus carina aculeatis.

L. Leaves halberd-strap-shoped, sitting; mid. nit prickly on the back.

LEAST LETTUCE. Ditch hanks and pastures in a chulky soil; rare vear Bingham, hefore you enter the lown from Bitcesford, on the right hand banti. Rev. G. Cna BBi.

B. August.

PRENANTHES. Smilh. 8i1. With 678 . Recept. nudum. Cal. calyculatus. Pappus simplex, subsessilis, Flosculi simplici serie.

Receptacle naked. Caly $\mathrm{x}$ double. Duwn hairs like, nearly sitting. Florets in a single row.

muralis. P. flosculis quinis, foliis runcinatis.

P. Florets 5 : leaves notihed.

IVY-LEAVED LETTUCE. Wall, shady woods and thichets Ualam and Vidingley Hills; Eperstone: Park; Basford ('hurch; Yiet Lathe beiween Papplewick and Irickn:ll

LEONTODON: Smith. 822. With.679. 
Recept. nudum. Cal. imbricatus, squamis laxiusculis. Pappus simplex, stipitatus.

Receptacle naked. Calyx taled; the inner scales parallel, equal. Duwn hair-like.

L. squamis calycinis exteriorihus reflexis, fo. Taraxliis runcinatis dentatis glabris.

acum.

L. Outer scales of the calyx'entire, reflected: leaves smooth, notched and acutely toothed.

COMBON DANDFLION. Meadows, pastures, road sides, ditch bank; ; common. P. April-weJuly.

L. officinale. With.

HEDYPNOIS. Smith. 823 .

Recept. nudum, punctatum. Cal. imbricatus, calyculacis. Rappus plumosus, sessilis, in. æqualis.

Receptacle naked, dotted. Calyx tiled, dou. ble. Down feathered, sithng, unequal.

H. scapis unifloris, follis dentatis, scabris, hispida. flosculis ore pilosis apice glandulusis.

H. All the scales of the calyx upright: leaves toothed, very cntire, hispid: "bristle-like, hairs forked.

Leontodon, hispidum. LinN. With. 681.

IOUGH HIDY PNOIS. Meadows and pasturex. Newark, and Averham Mealows; Southwell. P. July.

H. scapis unifloris, foliis dentatis scabris, ca- hirta. lyce glabriusculo, seminibus exterioribus pappo destitutis.

H. All the scales of the calyx upright: leaves toothed, hairy; hairs undivided; outer row of seeds down-less. 
250 SYNGEN. POLYG. EQUALIS. Hieraciun:

Leontodon hirtum. LinN. Wth. 682.

autum. H. scapo ramose, pedicellis squomosis, folinalis. is lanceolatis dentato pinnatifidis glabriusculis.

H. Stem branched; fruit-stalks scaly; leaves spear-shaped, toothed, very ertire, smooth; down mostly sitting.

Ieontodon autumnale. LINN. With.

AUTUMNAL HEDYPNOIS. Meadows and pastures; comnon.

P. Angust.

HIERACIUM. Smith. 827. With. 682. Recept. nudiusculum, punctatum. Cal. im. bricatus, ovatus. Pappus simplex, sessilis.

Rerept. generally naked. Calyx tiled, egg-. shaped: sometimes double. Duwn mossly suting, hair-like; rarely feathered.

* Scapo nudo unifloro.

1 Stalk leafless, 1 flowered: down simple.

Pilosella. H. foliis ellipticis integerrimis subtus tomentosis, stolonibus repentibus, scapo unifloro nudo.

H. Leaves very entire, egg-shaped, cottony underneath; suckers ireeping.

MOUSS-EAR HAWKWRLE. Very dry meadow, pastures, and walls; combion. Newark; Southwell; Man, liels!.

* Caule folioso.

2. Slem leafy. Down sitting.

Murorum. H. caule paniculato, foliis radicalibus ova. tis dentat is majoribus.

H. Stem branched: root leaves egg-shaped. loothed: stem leisf smaller. 


\section{SYNGEN. POLYG. ÆQUALIS. Crepis. 25s}

WAI, HAWRWEFD, GOLDF. IUNGWORT. Wooks, old walle, shady banks, and balks of corn-ficlds. Southwell Minster; Rocks in Nottingham Park.

P' July.

H. caule erecto multifloro, foliis ovato-lan-sabaudum. ceolatis dentato-serratis subamplexicaulibus subtus scabris.

H. Stem upright, many flowered: leaves eggspear-shaped, toothed, half embracing the stem.

SHRUB!Y BROAD-IFAVED HAWKWEED. Woods and hedges. Litingley Hill; Halam Hill; Warsop Woods.

P. August, Sept.

H. caule erecto subumbellato, foliis linearibus umbelsubdentat is sparsis.

latum.

H. Leaves strap-shaped, snmewhat toothed, scattered: flowers in a sort of umbel.

NARROW-LHAVED HAWK IFED. Hedges and dry shady places, anongst gorse. Stapleforil and Langfurt Moors; in Mr. Pocklington's plantation, Barnby Line ; between Coddington and Barnby ; and near Bulverton P. August, Sept.

CREPIS. Smith. 347. With. 688.

Recept, hispidiusculum. Cal, calyculatus, squ!amis deciduis demum torulosus. Pappus simplex, substipitatus.

Recept. naked. Calyx double, the outer one deciduous. Down hair-like, sometimes standing on a pedicle.

C. foliis radicalibus runcinatis; caulinis am-tector \&m. plexicaulibus lanceolatis dentatis, caule glabro.

C. Leaves spiar.shoped, notched; sitting, smooth; the lower ones touthed. 
352 SYNGEN. POLYG. AQUAL Hypocharis.

SMOORI IAWX'S-BEARD. SMOOTH SUCCO-

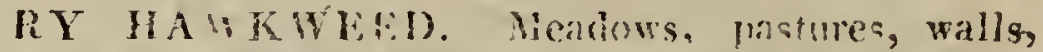
roofs;routl sides. Newark hieadows; $S$ athwell.

A. Junc --sent.

Giennis. C. follis runcinato pinnatifidis scabris: lobis antice dentatis, calyce muricato subtomentoso.

C. Leaves notched, with winged clefts, rough toothed arithin the base: calyx bristly.

ROURI! IA WK'S-BFIPD Meariowa and pasteres in a calcarrous soil, Halam bill ; Ox:0!1 llill.

13. Iune, July.

HYPCOH压IS. Smith 8.s. With.691.

Kecept. paleaceum. Cal. subimbricatus. Pabpus plumosus.

Recept. chajly Calyxisomewiat tiled. Down on a pedicle; feathered.

glabra. H. glabriuscula, calycibus oblongis imbrica. tis, caulibus ramosis sutfoliosis, foliis dentato sinuatis.

H. Smooth: stem branched, leafless: leaves toothed and indentia: calyx oblong, iiled.

SMOOTH CAT'S EAR. Samly and gravelly soils; rare. Oxton liurest.

A. Jure---August.

radica. $\mathrm{H}$. foliis runcinatis obtusis scabris, caulibus

ta. rumosis nudis lævibus, pedunculis squmosis.

H. Siembranched, naked, euen: leaves notched, blunt, rough: fruit.stalks scaly.

LONF-PCOTED CAT'S-FAR. Mealows and pastures; frequent. Ne:ark; Southwell. P. June-. Aug. 


\section{SYNGEN. POLYG. EQUAL. Lapsana. 25}

LAPSANA. Smith. 842. With. 693 .

Recept. nudum. Cal. calyculatus; foliolis interioribus æqualibus, canaliculatis, Semina mutica.

Recept. naked. Calyx double, all the inner scales channelled.

L. calycibus fructus angulatis, caule panicu-commue lato, pedunculis filiformibus. nis.

L. Calyxes after fiowering, angular: fruitsialks slender, very much branched.

NGPPLE-WORT. Hedges, shady places, cultivated ground, and ansongst rubisish; very conmon.

A. June, July.

CICHORIUM. Smith. 843. With.693.

Recept. subpaleaceum. Cal. calyculatus. Pappus paleaceus, semine brevior.

Recept, somewhat chaffy. Caly x double. Down about 5 teeth, indistinctily hairy.

C. Floribus geminis sessilibus, foliis runcina- Intyburo tis.

C. Flowers in pairs, sitting: leaves notched.

WILD SUCCORY. Borders of cornfields. Fields at Normanton, near Southwell; Road sioe between Norwood and Kirklington. P. July, August.

* CAPITATI. Flosculi tubulosi, apice di. varicato-patuli.

ARCTIUM. Smith. 844. With.694.

Cal. globosus; squamis apice hamatis inflex. is. 
254 SYNGEN. POLYG. EQUALIS. Carduus.

Calyx globular: scales with hooked points, bent inwards.

Lappa. A. foliis cordatis inermibus peticlatis.

A. Leaves heart-shaped, without thorns, on leaf-stalks.

BURDOCK. CLOT-BUR. Road sides, rubbish, and ditch banks; common. $\quad$ B. July, Ausust.

CARDUUS. Smith. $8_{47}$. With. 697 .

Cal. ventricosus, imbricatus: squamis spinosis. Recept. pilosum. Pappus deciduus.

Calyx bellying, tiled; scales thorny: Receptacle hairy.

* Foliis decurrentibus.

1. Leaves decurrent.

lanceo- C. foliis decurrentibus pinnatifidis hispidis : latus. laciniis divaricatis, calycibus ovatis villosis, caule piloso.

C: Leaves with winged clefts, hispid: segments straddling: calyxes egg-shaped, thorny, woolly: stem hairy.

SPEAR THISTLE. Rubbish, road sides, and waste places; very common, B. Junt---Sept.

mutans. C. foliis interrupte decurrentibus spinosis, floribus cernuis, squamis calycinis lanceolatis superne patentibus.

C. Leaves decurrent half-way down towards the next below; thorny: fruit-stalks crooked: calyx scales expanding upwards.

MUSK TIISTLE. Pastures in a calcareous soil, and road sides in a sandy or gravelly soil. Newark; Southrell.

A. July, August. 
C. foliis decurrentibus sinuatis spinosis, ca. acanlycibus glubosis subpedunculatis; squamis thoides. linearibus recurvatis.

C. Leaves indented, thorny at the edge: calyxes on truit--stalis, solitary, upright, woolly.

CUR!ES or WFBTE TH THSTLE Diteh benks, on

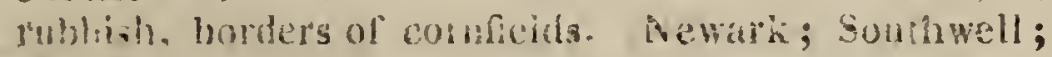

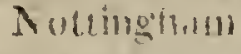

C. foliis decorrentibus pintatifis dentatis palusspinosis scabris, calycibus ovatis aggregatis tris. spinulosis, pappo plumoso.

C. Leaves toothed, thorny at the edge: flowers in bunches, upright: fruit-sialks without thorns.

MARSI THISTLY. Marshy mealows, moist shady places, and wet pastures; frequent. B. July, Aug.

* Foliis sessilibus.

2 Leaves sittiug.

C. foliis sessilibus pinnatifidis spinosis, caule arvenpaniculato, calycibus ovatis spinulosis, pap- sis. po plumoso.

C. Leaves silting, with winged'clefts, thorny at the edge; calyries egg-shaped, thorny: down feathered.

Serratula arvensis. With. 696 .

CRFEPINC THISTLE. WAY THISTLE. Cornfiedls and roud sides; very common. P. July.

C. foliis amplexicaulibus repandis spinosis; mariaradicalibus pinnatifidis, sqamis calycinis fo. $n u s$. liaccis refractis margine aculeatis. 
256 SYNGEN. POLYG. EQUAL. Onopordum.

C. Leaves embracing the stem, halbcrd-shaped and wing-cleft; thorny: caly $x$ without any teaves near it: thorns channelled, and set with other lattle thorns.

WILK TIYSTLE. Ditch banks, mad sides, borlers of cornficlds, and on rubbish. Newark; Blidworth.

A. Angust.

sriopho. C. foliis sessilibus bisariam pinnatifidis spirus. nosis scabris: laciniis alternis erectis, calycibus globosis villosis.

C. Leaves with wingea clefts pointing 2 ways, ciery other segment upright: calyxes globu= lar, woolly.

WOOLLY-HEADED THYSTLF, Both in nat and mountainous readlows and postures. Outerlies at Norman'on; Kirklington; Roadside heyond Dehdon Hill Tollbar; ( aur.t n: hy the side of the Road from Sont!gvell to Thurgarton, on the High Cross Hill. B. Alig.

veaulis. C. acaulis, calyce glabro.

C. Stemless: calyx smooth.

D.WARF THISTEF. Monntainn!rs and diry pastures, especially in a calcarenus soil. Sherwond Forest, plentifully ; Road on the Forest between Budby and Ollerton ; on a Common between Darlton and Freat Markham, near Tuxford.

P. July, August.

ONOPORDUM. Smith. 856 . With. 704 .

Cal. ventricosus; squamis patentibus, spino. sis. Recept. favosum, subpaleaceum.

Recept: like a honeycomb. Calyx bellying. Scales sharp-pointed.

Acan- O. calycibus squarrosis: spinis subulatis, fothium. liis ovato-oblongis sinuatis utrinque lanatis. 


\section{SYNGEN. POLYG. IEQUALIS. Carlina. 257}

O Calyx scales expanding, their points slanding out: leaves egg oblong, ina'ented.

COTTON THIS ILE. On rubbish and road sides; cnm. mon.

B. July。

CARLINA. Smith. 857. With. 704.

Cal. ventricosus; squam's exterioribus spinosis; interioribus coloratts, scariosis, radiantibus. Recept. paleaceum. Pappus plu'mosus.

Calyx radiated; the scales next the blossoms long coloured.

C. canle mult:floro corymboso, floribus ter vuigaris. minalibus, squamis calycinis exterioribus pinnatifidis; interioribus albidis.

C. Stem with many flowers in a corymbus: flowers terminating: rays of the calyx yel. low-zuhite.

COMMON CARLIVE. Dry mendows, pastures, commons, and hedge hasks bherwoud Forest; a'vout Mansfield; on the Forest between Rufford and Thoresby.

B. '?une.

* * DISCOIDEI. Flosculi tubulosi, erecto paralléli, apice planiusculi.

BIDENS. Smuth. 858. With.705.

Recept. paleaceum. Pappus aristis retrorsum scabris. Cal. polyphyllus. Cor. subinde ra. diata.

Recept. chaffy. Down rough with straight awns. Calyx tiled. 
258 SYNGEN. POLYG. EQUAL. Eupatorium:

tripar. B. foliis trifidis, calycibus basi foliosis, scmitzta. num ariscis erectis subternis.

B. Leaves 3-cleft: seeds upright.

TRIFID BUR MARYGOLD. Marhy and watery places, and sides of ponds. Sides of the two Ponds in $\Lambda$ ppleton Closes, Newark; ditches in Collingham Meadows.

A. August, Sept.

cernua. B. foliis lanceolatis serratis, floribus cernuis basi foliosis, seminum aristis erectis sub. quaternis.

B. Leaves spear-shaped, embracing the stem: flowers on crooked fruit-stalks: seeds upright.

NODDING BUR MARIGOLD. Wet ditches, and marshy places; not very common. Sides of a mitddy Pond, near the Flet, at North Collingham; near where B. trijartita grows, but not so pleatiful; Eding. ley Moors; Farnsfield Carr.

A. September.

EUPATORIUM. Smith. 859. With. 706. Recept. nudum. Pappus scaber. Cal. imbricatus, oblongus. Stylus semibifidus, exsertus.

Recept. naked. Down feathered. Calyx ob. long, tiled. Style lorg, cloven half-way down.

canna. E. foliis digitatis.

binum. E. Calyx 5-flowered: leaves with finger-like divisions.

HFMl' ACRP! MONT. Banks of rivers and brooks. Park ditches at Sonthwell; in brooks at l:adby, near ollerton; ditches between Ratclial and Nottinghan.

P. Joly, August. 


\section{POLYGAMIA: SUPERFLUA.}

\section{*DISCOIDEI.}

TANACETUM. Smith. 862, With. 708.

liecept. nudum. Sem. coronata. Cal. imbricatus, hemisphæricus. Flosculi radii trifidi, obsoleti, interdum nulli.

Recept. naked. Duwn none. Calyx hemis. pherical, taied. Flurets of the curcumference 3-cleft, narrow.strap shaped; sometimes wianting.

T. foliis bipinnatifidis incisc-serratis nudis. vulgare.

T. Leaves áoubly winged, cut, serrated.

COMAON TANST. M!ountainous mearows and pastures. Banks of the diches, heyond "ewark Brirge, on the Kelham lioad: by the road side betwcen the 2d and 3 d mile sione; beyon I the bleach yard on the Lincoln Road from Neuark, isbuidantly. P. July, Aug.

ARTEMISIA. Smith. 863. With. 708.

Recept. nudum, aut villosum. Sem. mutica. Cal. imbricatus, squamis rotundatis, conniventibus. Flosc. radii subulati, integerrimi.

Receptable either slightly hairy, or naked. Duwn none. Calyx tiled; the scales roundish, closing. Florets radiate, none.

A. folis multipartitis sericeo-incanis, flori-Absinbus hemisphæricis pendulis, receptaculo tham, piloso: 


\section{SYNGEN. POLYC. SUPERF. Gnaphalium.}
A. Leaves compound, many-cleft: flowers some- what globular, pendent: recepiacle woolly.
COMHON WORMWOOM. Road sides, stony plices, and arnong rubbish; conmon. Bowbritge Lane, New- ark; between Win horpe and Langford; and "olling- him, plentıfully.
P. August.

volgaris. A. foliis pinnatifidis planis incisis: subtus toméntosis, racemis simplicibus, floribus ovatis, receptaculo nudo.

A. Leaves wing-cleft, flat, cut, cottony uncierneath: bunches simple, bending : floreis of the circuimference 5 .

MUGWORT. Borders of fields, dich banks, and on rabbish; common: Newark; Southvell; Nottingham.

P. Aurist.

GNAPHALIUM: Smith. 867. With. 711.

Recept. nudum. Pappus scaber, aut plumosus. Cal imbricatus, squamis scariosis coloratis. Flosc. radii subulati. Flosculi aliquot disci subinde abortivi.

Receptacle naked. Down hair like, or feathered. Calyx tiled. Scales at the edige roundish, shinny, coloured.

rectum. $G$. caule erecto paniculato multifloro, foliis linear i.lanceolatis supra denudatis.

G. Stem upright, terminating in a leafy compound spike: leaves strap-spear-shaped, al. most naked on the upper side.

UPRIGHT WOOI) CUD WEED. Pastures and woods in a sandy soil. In Earl Harrington's Plantation, at Blidworih; Bilsthorpe.

P. August.

uligino-G. caule ramosissimo diffuso, floribus con. sum. tertis terminalibus. 
SYNGEN. POLYG. SUPERFL. Conyza. 261

G. Stem branched, spreading: flowers crowd. ed, terminating.

MARSI CUDWEED. In watery piaces, especially where stagn: nt water has stood during the winter. Newark; Southwell; Mansfield. A. August.

G. caule erecto dichotomo, foliis lanceolais, germe. capitulis globosis multifloris lateralibus ter- nicum. minalibusque.

G. Panicle forked: flowers roundish, axillary, hairy : leaves acute.

COMMOY CUD WTE!), Täran mealow, matures, and road siles, Newark; Southwell; P.dineley Moers Oxton Bottoins.

A. J!:ly, August.

CONYZA. Smith. 875. With. 717.

Recept. nudum. Pappus scaber. Cal imbricatus, subrotundus. Flosc. radii trifidi.

Recept. naked. Down hair-like. Calyx tiled, roundish. Florets of the circumference 3 . cleft.

C. foliis ovatolanceolatis pubescentibus, squar. caule herbaceo corymboso, squamis calyci- rosa. nis squarrosis foliaceis.

C. Leaves spear-shaped, acute: stem herbaceous: flowers in corymbus: scales of the ca. lyx with their points turned outwards.

PLOWMAN'S SPIKENARD. Mountainons meadows and pastures, and road sides in a calcareons soll. On. the Road half-way between Ketford and Worksop) near Mir. Foljambe's House, at Osberton. B. July, Aug.

$$
\text { * RADIATI. }
$$

ERIGERON. Smith. 875. With. 717 . 
262 SYNGEN. POLYG. SUPERFL. Tussilago.

Recept. nudum. Pappus simplex. Cor. radii lineares, angustissina, numerosa. Cal. imbricatus.

Recept. naked. Down hair-like. Florets of the circumference strup-shaped, very narrow.

acre. E, caule racemoso, pedunculis subunifloris, folitis lanceolato-lingulatis sessilibus.

E. Fruit-stalks allernate, with 1, 2, oi 3 flow. ers.

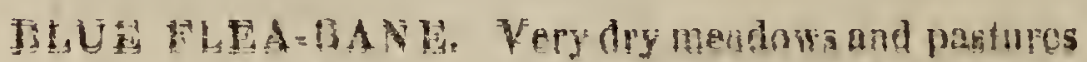
in 4 ealareous soll In a Close behind Mr. Hontague's House, at "apllewick; Bulwell Lime Quaries; on Sparken Hill, near Worksop. B. Iuly, August.

TUSSILAGO, Smith. 878. Wilh. 719 . Recept, nudum. Pappus simplex. Cal, sim. - plex, polyphyllus, æqualis, submembrana. ceus, basi ventricosus.

Recept. naked. Down hair-like. Calyx scales equal, as tall as the surface of the florets, somewhat membranaceous.

Farfara. T. scapo unifloro squamoso, folis cordatis angulatis denticulatis.

T Stalk with 1 flower; tiled: leaves somewhat heart-shaped, angular, finely toothed.

COI'T's-HoOT. Poctres and moistish places, in moist, stitf, clavey soil, and on limestone rubhish; comnon. Southwell; Newart. I'. March, April.

Bybriáa. T. thyrso oblongo, flosculis famineis plarimis ; hermaphroditicis paucissimis, anthe. ris discretis.

T. Panicle oblong : female flowers numerous, wathout blossoms. 
SYNGEN. POLYG. SUPEREL. Senecis. $2 \sigma_{3}$

IOVGER-STALKFD BUTTER-BUR. Moist meadows, and bankis of ditches. Soublireli Cotton Mill.

P. April.

T. thyrsn ovato, flosculis omnibus fere her. Petasimaphroditicis syngenesiis.

tes.

T. Panicle egg-shaped: female florets ferw. LiNN. Entirely wanning in our plants. WUODWARD.

- CONMON BUTTER-BUR. Moist mearhrs and nas. tures, and bonks of rivers. Cirect-Bridge, Southweil; Marshes at Mansfield. P. April.

SENECIO. Smith. 881. With. 721.

Recept. nudum. Pappus simplex. Cal. cylindricus, polyp!ryllus, requalis, calyculatus, squamis apice sphacelatis.

Recept. naked. Down hair like, long. Calyx concal, double; the scales as if dead at the ends.

* Floribus flosculosis.

\section{Florets all tubular.}

S. floribus radio destitutis sparsis, foliis pin-vulga. nato-sinuatis amplexicaulibus dentatis. ris.

S. Leaves winged.indented, embracing the stem: flowers scattered.

COMMON GROUNDSEL. SMMON. Cultivated ground, rubbish, and road sides; very comnson.

A. April--.Sept.

* Floribus radiatis, radio statim revoluto.

2 Strap-shaped florets in the circumference rolled back. 


\section{$26_{4}$ SYNGEN. POLYG. SJPERFL. Solidago.}

syluati-S. radio revoluto, follis pinnatifidis lobatis cus. denticulatis, calyculo brevissimo, caule erecto stricto corymboso

S. Leaves wing-cleft, finely toothed; stein branching into a corymbus; upright.

MOUNTA VGR UNDSBl. Dry gravelly heaths, and saudy dich banks; not uncommon. Q.uonce-hill Close, at vewark; Oxton; Lartifield. A. July.

*** Floribus radiatis, radio patente; folis pinnatifidis.

3 Strap-shaped florets in the circumference expanding : leazes wing cliffi.

tenuifo S. radio patente, follis pinatindis subrevolu. laus tis subtus pallidiorbus pubescentibus, caule erecto villoso.

S. Leaves winged; segments sirap-shaped; lower leaves on long leaf.stalks: flowers forming a corymbus: stem upright.

GROUNDSEL RACW OR R. Woods and hedges. Halain and Oxtois Hillo. P. July, August.

Fucobcei S. radio patente, foliis lyrato-bipinnatifidis divaricatis dentatis glabris caule erecto.

S. Leaves lyre-shaped, almost winged: segments finely jagged: siem upright.

COMMOA RAGWOR $\mathrm{C}$. Nicatlows, pastures, and road sides ؛ very common. P. July, August.

aquati S. radio patente: flosculis cllipticis, foliis lycus. ratis serratis; inferioribus oboratis integris, seminibus glabris.

S. Leaves toothed, those at the root egg-shaped, those of the stem wing cleft; the outer segment largest. 
SYNGEN. POLYG. SUPERF. Solidago. 26.

MARSI RAGWORT. Ditches and watery places, and noist merduws. Ldingley Moors; Farnsfield Carr; Oxton Stews.

P. July, $\Lambda$ ugust.

SOLIDAGO. Smith. 889. With. 727 .

Recept. scrobiculatum, nudum. Pappus simplex. Cal. imbricatus, squanis conniventibus. Floscul radii circiter quinque.

Recept. naked. Down hair.like. Florets of the circumference about 5 . Caly $\mathrm{x}$ scales tiled, laid close.

S. caule subflexuoso angulato, racemis pani-Virgaltculatis erectis conferis.

rea.

S. Stem serpentine, branched: leaves mostly sitting : flowers in crowded panicles.

COMMON GOLDEN ROD. Woods, hedges, heaths, copses. Banls between Coddington and Barnby.

P. July---sept.

INULA. Smith. $89^{\circ}$. With. $73^{\circ}$.

Recept. nudum. Pappus. simplex. Cal. imbricatus. Cor. radii numerossissima, lineares. Anthere basi bisetz.

Receptacle naked. Down hair-like. Anthers with 2 bristles at the base.

I. fuliis amplexicaulibus cordato-oblongis to- dysenmentosis, caule villoso pariculato, squamis terica. caly cinis setaceis hirtis.

I. Leaves embracing the stem, heart-oblong: stem woolly, forming a kind of panicle: scales of the calyx bristle-shaped.

COMMOY FLIA B.ANE. Kioist meadows 2:1 pastures, watery pluces, sides of bruoks and rivule!s. Lualids of 
the ditches heyond Newark Bridge, on the Kelham Road; Southwell; Nottingham; Mansield. P.Aug.

BELLIS. Smith. 897. Wilh. 733 .

Recept. nudum, conicum. Pappus nullus. Cal. hemisphæricus, squamis æqualibus. Sem. obovata.

Recept. naked, conical. Down none. Calyx hemispherical, with equal scales. Seed inversely egg-shaped.

perennis. B. scapo nudo, radice repente.

B. Stalk naked.

COMMON DAISY. Meadows and pastures, very common.

P. March-..-Sept.

CHRYSANTHEMUM. Smith. 898. With. 733 .

Recept. nudum. Pappus nullus. Cal. hemisphæricus, imbricatus, squamis margine dilatatis, membranaceis.

Recept. naked. Down none, but a kind of border. Calyx hemispherical, tiled; scales membranaccous at the edge.

$$
\text { * Radio albo. }
$$

1. Florets of the circumference white.

Leucan-C. foliis amplcxicaulibus oblongis obtusis themum. incisis basi pinnatifidis; radicalibus obovatis pctiolatis.

C. Leaves embracing the stem, oblong; serrated upwards, toolhed at the base.

GRYAT WIITE OK-EYE. Dry Meadows, pastures, ...h vills. Newark; Southwell. P.June, July. 
SYNGEN. POLYG. SUPER. Pyrethrum. 257

* Radio luteo.

2 Flowers entircly yellow.

C. follis amplexicaulibus glaucis superne la- segetum ciniatis basi dentatis.

C. Leaves embracing the stem, jagged upwards, tooth-serrated towards the base.

YEA,OW OX-BYF. CORN MARIGOLD. Cornfie!ds ; very common. A. June--August.

PYRETHRUM. Smiti. g00. Wath. 735.

Recept. nudum. Pappus marginatus. Cal. hemisphæricus, imbricatus, squamis acutiusculis; margine scariosis.

Recept. naked. Down none. Calyx hemispherical, tiled; scales rather pointed, skinny at the edge.

P. follis petiolatis compositis planis: foliolis Partheovatis incisis, pedunculis ramosis corymbo- nium. sis, caule erecto.

$P$, Leaves compound, flat; leafits egg-shaped, cut: fruit-stalks bianched.

Matricaria parthenium. With. 735 .

COMMON FIVER-FFiv. Waste places, hedges, and walls on the right hand sille the roal after you Fiss by the Clumeh at Kakring. Upton strect on binks; a bank near Mir. Gilbert's houst, liutle carl:nn, near Mustibam.

i. June, duly.

P. foliis sessilibus pinnatis capillaceo-multi- inodos fidis, caule raniuso patulo, corona.seminum runio integra.

P. Leaves winged, many-ileft: slem branched, spreading. 
SYNGEN. POLYG. SUPERFL. Anthemis. 268

Chrysanthemum inodorum. With. 734 .

CORN FEVER-FEW. SCENTLTSS MAY-WEED.

Cornfields and road sir?es. Amongst corn in Pcaconficlds, Newark; by the road side near the one mile sione between Southwell and Upton. A. Aug. Sept.

ANTHEMIS. Smith. 903. With. 737 .

Recept. paleaceum. Pappus submarginatus. Cal. hemisphæricus, squamis subæqualibus. Flosculi radii plures quam quinque, oblongi. Recept. chaffy. Down. none. Calyx hemispherical, scales nearly equal. Florets of the circumference more than 5 .

Cotula. A. receptaculo conico; paleis setareis seminibus muticis, foliis bipinnatifidis glabrius. culis.

A. Receptacles conical: chaff brisile shaped: seeds naked.

STINKING MAY-WFCD, or CHAMOMILF. Comfields, road sides, and borders of dunghills. Newark; Southwell; Minsfield.

A. June, July.

ACHILLEA. Smith: 908. With. 741.

Recept paleaceum. Pappus nullus. Cal. ovatus, imbricatus, inæqualis. Flosculi radii quinque ad decem, obcordato subrotundi.

Recept. chaffy. Down none. Calyx eggshaped, tiled: strap-shaped florets from 5 to 10.

Ptarmi-A. foliis lanceolatis acuminatis argute scrraca. tis.

A. Leaves strap-spear-shaped, embracing the stem, fine'y serrated. 


\section{SYNGEN. POLYG. FRUSTRA. Centaurea. 269}

SNEEZE-WORT. YARROW. GODSE-TONGUE. Moist meadows and shady places, and balks of cornfields. Lidingley Mioors; Stapleford and langford Moors.

P. July, August.

A. foliis-bipinnatifidis pilosis : laciniis lineari- Millebus dentatis, mucronatis, caulibus sulcatis. folium.

A. Leaves doubly winged, segments of the wings strap-shaped, toothed.

COMMON YARROW. MILFOTL. Meadows, pastures, and road sides; very common. P. June--A A g.

\section{POLYGAM. FRUSTRANEA.}

CENTAUREA. Smth. 999. With. 742 . Recept. setosum. Pappus simplex. Cor. radii intundibulitormes, longiores, irregulares.

Recept. brastly. Down either feathered or harr-lik. Florets of the circumference funnel-shuped, irregular, longer than the others.

* Cal. squamis apice ciliatis

1 Srales of the calyx serrated with fringe.

C. squanis calyrinis ovatis : c1liis capillari- nigra: bus erectis, foliis inferioribus lyrato-angulatis superioribus ovat is.

C. Culyx scales egg-shaped, fringe hair. like, upright. luwer leaves lyre-shaped, angular; upper ones ego.strap-spear-shaped, and nearly entire.

BLACK, :T I.FSיER KNAPWEED. Meadows and pastures; very coinunon. Newark; "nithivell

P. ine--August.

A. ${ }^{3} 3$. 


\section{SYNGEN. POLYG. FRUSTRA. Centaurea.}

Cyanus. C. squamis calycinis serratis, foliis linearibus integerrimis; interioribus dentatis.

C. Calyx scales ser rated: leaves strap-shaped, very entire; the lower ones toothed.

COR V BLUE-BOTtLE. Cornfielts; common. Beacon-fields, Newark; Southwell; Mansfield.

A. July, Aug.

Scabiosa. C. squamis calycinis ciliatis ovatis, foliis pimnatifidis : laciniis lanceolatis subdentatis pilosiusculis:

C. Calyx scales fringed: leaves wing-cleft; segments spear-shaped.

GRIATER KNAPITED, Borders of fields, and amongst corr, r.nt uncommon. Beacon Hill, Newark; Halain; Furnstield. P. July, August. 


\section{Classis $X X$.}

\section{GYNANDRIA.}

Stamina pistillo, supra germen, inserta. Stamens on the pistil.

\section{DIANDRIA.}

Stamina 2.

Siamens 2.

ORCHIS. Nectarium. corniculatum. ORC.HIS. Nectary ending in a spur. SÁTYRIUM Nectarzum inflato-didymum:

SATYRIUM. Nectary ending in a purse.

OPHRYS. Nectarium subcarnatum, deflexum. OPHRY: Nectary somewhat keeled

SERAPIAS. Nectarium ovatum, gibbum, labio ovato.

SER ·PIAS. Nectary egg.shaped; bulging on the under side. 


\section{GYNANDRIA. DIANDRIA. Orchis.}

\section{GYNANDRIA.}

\section{DIANDRIA.}

ORCHIS. Smith. 918. With. 21.

Neclarium corniforme, pone florem.

Nectary like a horn, behind the flower. Blosson gaping.

* Bultis indivisis.

1 Bullss of the root undivided.

bifolia. $O$ bulbis inciivisis, nectarii labio lanceolato integerrimo: cornu longissimo, petalis lateralibus pateutibus.

O. Lup of the Nectary spear-shaped; very entire: horn very long : petals expanding.

BUTCEKFIYY OBCHLS. Woods aid thickes in a clityey soll: not uncommon thesthorpe, near South. well; an! in the following woods, : Ixten. Kirhlineron, Win burr, winher, leperstone, Elintham, Ossingon, Mu-kham, Mershıs, anıl olwick. P. May, Jube.

B. Orchis bifulia. Smuth. 918.

Var. 3. Leaves. 2 or 3. spear-shaped.

Meadows and and pastures; not common. sonthwell ; : nd in the mendows leating o oxton Wood; also closes be: ween $W$ inkburn and f irtlington. $\quad P$ : June.

The Orchis bifolia, is not wentioned hy DFF IR G, who states that the breleis baripta toeditia. "RAv's svv. ". T6, was foumd by him at the bontom of Clition Hill, in spril, and: in the begenning of May, in Colwick Wond." This plat mus? unquevionably have been

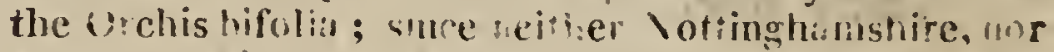
any cownty except kes: all hoss of thin very sarce plant, the Urchis barbata foetida of $R_{A} Y$, the Satyriuce. 


\section{GINANDRIA. DIANDKIA. Orchis. 273}

hircinum of I I N N X S, which flowers in Tune and July, and is justly denominated, in the Flora Britannica, the most rare of all the Brilish Orchiteæ. It wals pointed out to $\because$ utw in 1791, by the late Ar. Lrwis, at Darent near Dartford; aul, had it not been for this fortunate discovery, we must have rulied, as we have done for more than a century, upou the sole authority of the diligent and accurate $K A Y$.

O. bulbis indivisis, nectarii labio trifido pyramixquali integerrimo superne bicorni: cal- dalis. cari elongato filiformi.

O. Lip of the nectary 2.horned, 3 cleft; seg. ments equal, very entire: horn long: petals somewhat spear shaped.

PYRAMIDAL ORCHIS. LATE-FTOWERINA ORCUIS. Dry pas:ures and meadows in 2 calcarcout soil; not very common. Southwell; in a line, the foot-rood hetween Winkburn and Kirklinginn: Bean con Field to e- its, near Newark; Asplly; in Mr. Bicliy's meatow neir Osmanthorye ; in the ave. nue leading to ors:oud. June, July.

O. bulhis indivisis, nectarii labio quadrifido Morio. crenulato: cornu obtuso ascendente, peta. lis conniventibus mutinervibus.

O. Lip of the Nectary, 4 cleft, finely scolloped: hirn blunt, ascending: petals blunt, approaching: lip of the nectary with 3 lobes, the middlemost notched at the end.

MFADOW ORCHIS Moistish meadowa and nastures; frequent. Sonth well ; Newark.

P. Niay, !nne.

$O$ bulbis indivis's, nectarii labio quadrifido mascula. crenulato; cornu obtuso, petalis exterioribus reflexis trinervibus.

O. Lip of the nectary 4 -lobed, finely scolloped: horn blunt: upper petals turned back. 


\section{GYNANDRIA. DIANDRIA. Orchis.}

EARIY PURPLE ORCIIS. Meadows ant pastures; common. Southwell; Newark; Nottinglim; Mansfield.

P. May.

ustulata. 0 . bulbis indivisis, nectarii labio quadrificlo punctis scabro, cornu obtuso brevissimo petalis distinctis.

O. Lip of the nectary with 4 clefis, rough with dois: loornbiunt: petals distinct.

DIV A:F ORCIIIS. Dryish mearlows ant pastures

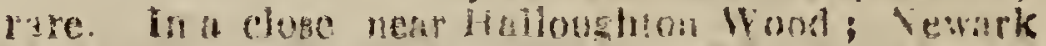
and $A$ verium Veadows; in the meatons on the bank of the Trent between Huzleford und Aoutingham.

H. May, June.

* Bulbis palmatis:

2. Bulbs of the root hand-shaped.

laiffolia. O. bulbis subpalmatis, nectarii cornu conico: labio trifido, bracteis flore duplu longioribus.

O. Bulbs somerihat hand shaped, straight: horn of the nectary conical: lip with 3 lobes; the lateral ones bent back: floral leaves longer than the flowers.

MAPSH ORCHES. Mnist mesdors and pastures, and marshy grount. Newark and Averham Mcadows, in a low situation; bog in the Quonec Clowe, Newark; lict close but ore before you naccul the hill to the Ice Hoise, Felham; Parks, Soutuwell; Gamstone Meadow, near yoti:guara.

P. Miay, June.

macula. O. bulbis palmatis divaricatis, nectarii corta. nu germinibus breviore : labio trilobo plano, petalis patentibus.

O. Bulbs expanding: horn of the nectary shorter thun the germen: lip flat: petals on the back upright. 
SPOTTED PALMATE ORCHIS. Wooks and rich meadows; common. :outhwell; Kirklington; Eloses adjcining Wemham Wood. Pune, duly.

O. bulbis palmatis, nectarii cornu setaceo conopgermminibus duplo longiore: labio trifido sea: integerrimo.

O. Horn of the nectary bristle-shaped, longer than the germen: lip cloven into 3 : two of the petals very much expanding.

A ROMATIC OR C.HIS. Meadows and nastures; rather rare. Roarl side of Bulwell hall, in a low situaticn; side of a water near Ki.lington mill ; In a meadow on the left-hand sicle the brilge which separates Halloughton and Thurgarton parislies; Camston Meadow, lear Nottilgham; Averham Neadow, near Newark. P. June.

SATYRIUM. Smith. 927. With. 29.

Nectarium inflato-didymum, pone florem.

Nectary behind the flower; inflated, roundish.

S. bulbis palmatis, foliis ovatis obtusiusculis, viride. nectarii labio lineari trifido; lacinia intermedia minina.

S. Bulbs hand-shaped: leaves oblong, blunt: ltp of the nectary strap-shaped, 3-cleft; the middle segment indistrnct.

FROG SATYRION. Meadows and pastures in gravelly soil; rather rare. Cotton-mill meadow, Soutliwell: Newark nud Arerham meadows, but not plentiful ; Mr. Willimot's neadow, at Normanton near Southwell ; a close near Thorney- moor holt, and by the side of Westhorpe dumble near Sonthwell; in the closes at the bottom of Oxton hill, by the foot path leading to the village.

$$
\text { P. June, July. }
$$

OPHRYS. Smith: 931. With. $3^{2}$.

Nectarium subtus subcarinatum, deflexum. 


\section{GYNANDRIA. DIANDRIA. Ophrys.}

Nectary slightly keeled underneath.

Nidus. O. bulbis fibroso-fasciculatis, caule vaginato avis. aphyllo, nectarii labıo bifido.

O. Bulbs fibrous, bundled: slem sheathed, leafless: lip of the nectary cloven.

BIRD'S-NEST OPURYS. Hoods and shady places; very rire. Fiperstove wools; Mis. CoAPE SugrBuonk. Lound woops; upper left-haud quarter, near Eakring; Brockwood-hill noods, near Thurgirion.

P. Mij, Juile.

-vata. $\mathrm{O}$. bulbis fbrosis, caule bifolio, foliis elliptiticis, nectarii labio lineari bifido.

O. Bulb fibrous: siem with two leaves: leaves egg-shaped: lep of the nectary cloven.

COMMON TWAYBLAS)E. Woods ind moist shady tbichets; not unfequnal. Nesarti and Averhan ineadows ; and in the following wouds, Elyerstone, Oxion, Colwick, Ossiagtoa, Fliuham, and Wermam.

P. June.

miuscifere. O. bulbis subrotundis, caule folioso, nectarii labio quadrilobo elongato convexiuscu. lo subpubescente, columna obtusa.

O. Bulbs roundish; stem leafy; lip of the nec. tary convex, cloth like, wath 3 divisions, the middle segment cloven.

FIY OPHRYS, or ORCHIS. Meadows and pastures in a calcareons soil ; but rare. bulwell lime Quarries, near Nottingham. Mirs. Padx E. Aspley Crounds. UeEring. P. Juie.

apifera. O. bulbis subrotundis, caule folioso, nectarii labio convexo villoso quinquefido: lacinia terninali recurvata subulata. 
O. bulibs roundish: stem leafy: lip of the nectary wath 5 lobes, the lobes bent in underneath, shorter than the petals.

B I OPHIRY but rare. Bulwell Line Quarries, with O. rinuscifesa. Mrs. PuLEY. Asply Gounds near Nottingliam. D) FRIN (: A few apecinchs have some years since, been fount by Mr TnouAs C'JARKE, of Kirby Hardwiche, in the grounds near his house;--1t has also been collected among the Quaries at Munsfield.

P. July:

SERAPIAS. Smith. 942. With. 40.

Nectarcum ovatum, gibbum, labio ovato.

Bliss. 6 petals expanding. Nectary egg-shaped, bulying. Lip egg shaped. Caps. beneath, 1-celled, 3-valved.

S. foliis ovatis amplexicaulibus, foribus cer-latifalia. nuis, labio integerrimo acuminato petalis breviore.

S.. Leaves egg-spear-shaped, embracing the stem: flowers nearly hornontal: lip pointed, entire, raticer shorter than the petals.

BROAD-LEAVED II FLLIRBORIN E. Woorls, groves, and hetges. Fperstone Wool; Loundes Wood, near Cakrine; Oxton-llood; and in a little wood on the hill hetween Ossington and Scarthingmoor; Wernham Woods. P. July, August.

S. foliis lanceolatis amplexicaulibus, foribus palus. cernuis, labio crenato obtuso petalis æquali. tris.

S. Leaves spear-shaped, embracing the stem: flowers nearly-horzzonial: lip scolloped, blunt, longer than the petals.

S. longifolia. Wath. 


\section{GYNANDRIA. DIANDRIA. Serapias.}

MAR SH HFLLFBORINF Marshy and watery places. Boggy ground in a close at Halam Beck, near Southwell; Edingley Moors; near Kirklington Mill; in a noist close at Coddington.

P.July, Aug.

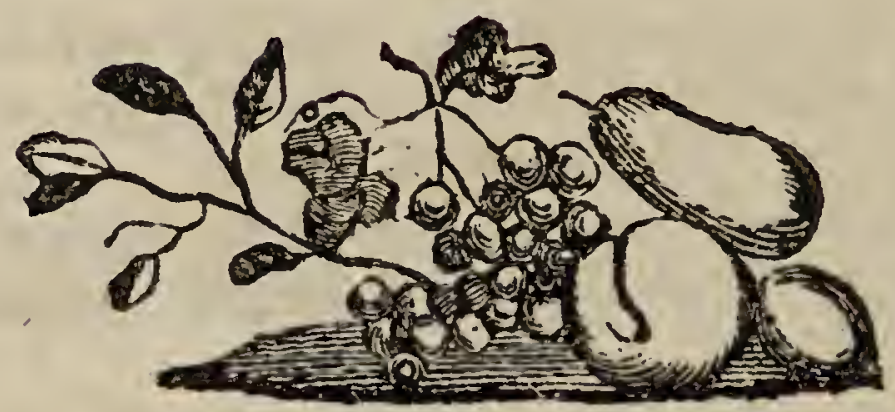




\title{
Classis $X X I$. MONOECIA.
}

Flores masculi et fæminei in eadem

\author{
planta. \\ DIANDRIA.
}

Stamina 2.

LEMNA. Mase. Cal. monophyllus. Cor, nulla. ram. Cal. monophyllus. Cor. nulla. Pist. quatuor: Sem. quatuor.

LEMNA. Male. Cal. I leaf. Bloss: none. Fæm. Cal. monophyllus. Cor. nulla. Stylus 1. Caps. polysperma.

LEMNA. M. Calyx 1 leaf. Bloss. none.

j. Capsule 1-celled.

\section{TRIANDRIA.}

Stamina 3 .

SPARGANIUM. Masc. Cal. triphyllus. Cor. nulla. Fæm. Cal. triphyllus. Cor. nulla. Drupa exsucca, monosperma.

$$
\mathrm{B}_{\mathrm{b}} 2
$$


SPARGANIUM. Catkin roundish. Cal. 3 leaves. Bloss. none.

F. Summit 2 cleft. Drupajuiceless, with 1 or 2 seeds. CAREX. Masc Amenium imbricatum. Cal. gluma univalvis. Cor. nulla.

Fàm. Ament. imbricatum. Cal. gluma univalvis. Cor. nulla. Stigmala 2 vel 3. Semen arillo ven. tricoso tectum.

CAREX. Catkin spike-lzke, tiled with husks. Cal. - leaf. Bloss. none.

F. Nectary inflated; with 2 or 3 teeth. Summits 3 , rarely 2 Seed 1, suting on the hair.like down.

TYPHA. MAsc. Ament cylindraceum, pilosum. Anth. subternice in filamento communi.

Frm. Ament. cylindraceum. Sem. s, pedicello pap. poso.

TYPHA. Catkin cylindrical. Bloss.none.

M. Cal indistznct, 3 -leaved.

$F$ Calkins under the male flowers; Cal. soft hairs. Sced 1, sitiing on the hair-like down.

\section{TETRANDRIA.}

\section{Stamina 4 .}

URTICA. Masc. Cal. tetraphyllus. Cor. nulla. Germinis rudimentum cyathitorme.

Fæm. Cal. diphyllus. Cor nulla. Sem. 1, superum, suitidum. 


\section{MONOECIA, PENTANDRIA。}

URTICA. Flowers male and female on the same, rarely on distinct plants.

M. Cal. 4 leaves. Nectary central; glass-shaped.

F. Cal. 2 values. Seed 1, glossy'.

BETULA. Masc. Cal. amenti šuuama monophylla, trifida, triflora. Cor. quadripartita.

Fæm. Cal. amenti squama monophylla, subtrifida, biflora. Styli 2. Semina compressa.

BETULA. Flowers male and female on the same plant. Cal. 3-cleft. Bloss. with 4 divisions.

M. Cal. containing 3 flowers.

F. Cal. containing 2 flowers. Seeds with a membra. naceous border on each side.

\section{PENTANDRIA.}

\section{Stamina 5 .}

BRYONIA. Misc. Cal. quinquedentatus, Cor. quinquefida. Filamen. 3. Anth. 5.

Fæm. Cal. quinquedentatus. Cor. quinquefida. Styl: trificus: Bacca infera, polyspeima.

BRYONIA. Stam. and pistil in separate flowers. Bloss. with 5 divisions.

Fem. Style 3.cleft. Berry somewhat globular, with many seeds. 


\section{POLYANDRIA.}

\section{Stamina 8 vel plura.}

MYRIOPHYLLÜM. Masc. Cal. tetraphyllus. Pet. 4. Stain. 8.

Fæm. Cal. tetraphyllus. Pet. 4. Stigmata 4. sessilia. Sem. 4. corticata.

MYRIOPHYLLUM. Flowers often $M$. and $F$. on the same plant. Cal. 4 leaves. Bloss. none.

F. Style none. Seeds 4 ; naked.

POTERIUM. Masc. Cal. tetraphyllıs. Cor. quadripartita. Stam. 30-40.

Fæm: Cal. tetraphyllus: Cor. quadripartita. Pist. 2. Nux. bilocularis, corticata.

POTERIUM. Flowers $M$. and $F$. on the same plant. Cal, 4 -leaved. Bloss. with 4 divisions.

F. Berry formed of the indurated tube of the blossom.

Fem. Drupajuiceless; bencail ; 1 or a celled; formed of the indurated tube of the blossom.

SAGITTARIA. Masc. Cal.' triphyllus. Pet. 3. Slam. fere 24 .

Fæm. Cal. triphyllus. Pet. 3, Pist. plurima. Caps. luprimæ, ventricosæ, monospermæ.

SAGITTARIA. Flowers $M$, and $F$. on the same plant. Cal. 3 leaves. Bloss. 3 petals.

Male. Filam. about 24.

Fern. Sceds many, naked.

CERATOPHYLLUM. Masc. Cal. multipartitus. Cor. n. li.. Siam. $16-20$. 
Fæm. Cal. multipartitus. Cor. nulla. Styli 2 vel 3 , trifidi. Sem. 2 vel 3 , calyce coriaceo, muricato, tecta:

CERATOPHYLLUM. Flowers $M$. and $F$. on the same plant. Bloss. none. Cal. with many divisions. FAGUS. Masc. Cal. campanulatus, quinquefidus. Cor. nulla. Stam. 5-12

Fæm. Cal. quadrifidus. Cor. nulld. Styli 2 vel 3 , trifidi. Sem. 's vel 3 , calyce coriaceo, muricato, tecta.

FAGUS. Flowers Male and Fem. on the same plant. Bloss. none.

Male. Culyx 5-cleft; bell shaped.

Fen. Calyx 4-toothed, charging into a capsule; prickly; 4 valued, a-seeded.

QUERCUS. Masc. Cal. campanulatus, subquinquefidus. Cor. nulla. Stam. 5-10.

Fæm. Cal. campanulatus, integerrimus scaber. Cor. nulla. Siylus 1. Stigmata 3. Nux supera, coriacea, monosperma.

QUERCUS. Flowers Male and Female on the same plant. Bloss. none.

Male. Calyx mosily 5-cleft. Stamens 5 to 10.

Fem. Cal. 1 leaf, very entire, 'rough. Styles 2 to 5 . Seed 1, egg-spaped.

CORYLUS. Masc. Cal. amenti squama trifida. Cor. nulla. Stam. 8.

Fæm. Cal. bifidus, lacer. Cor. nulla. Styli 2. Nux. ovdta, lævis, unilocularis, calyce coriaceo tecta.

CORYLUS. Flowers Male and Female on the same plant. Bloss. none. 
Male. Catkin tiled. Cal. 1 ceaf; 3.cleft, resembling a scale, inclosing 1 flower.

Fem. Cal. 1 leaf; a-lipped; ragged. Nut. egg.shaped. C.ARPINUS. Masc. Cal. amenti squama subrotun. da. Cor. nulla. Stam. 8-20.

Fæm. Cal. amenti squama oblonga. Cor. nulla. Germina 2. Styli singulis 2. Nux. angulosa, unilocularis.

CARPINUS. Flowers Mate and Female on the same plant. Bloss. none. Cal. iscale fringed.

Male. Stamens 101016.

Fem. Germens 2, with a styles on each. Nut eggshaped.

ARUM. Spatha monophylla. Cor. nulla. Spadix. androgynus, medio staminiferus, basi germiniferus. Bacca unilocularis.

ARUM. Sheath 1 leaf, cone-shaped. Sheathed Fruitst. naked above, bearing. Pistils below, and Stamens. in the middle.

\section{MONADELPHIA.}

Filamenta inferne in unum coalita.

Piuus. Masc. Cal. amenti squama peltata. Cor. nulla. Anthera squamis adnatæ, sessilis.

Fæm. Cal. amenti squama biflora, Cor. nulla. Pist. 1. Nux. alata.

Pinus. Bloss. M. and F. flowers on the same plaxt. Bloss. none. 


\section{MONOECIA. DIANDRIA. LeInna. 285}

\section{Cal. 4-leaved.}

F. a cone-lake Cutkin. Nuts 2 ; with a membrana. ceous wing.

\section{MONOECIA.}

\section{is DIANDRIA。}

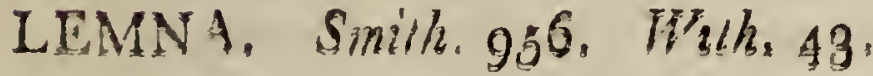

Masc, Cal, inonophyllus. Cor, nulla,

Fan. Cal. monophyllus. Cor, nulla. Stylus

1. Caps. polysperma.

Male. Cal, 1. Leuf. Blossonone,

Fem. Cal. 1 leaf. Bloss, none. Style 1. Caps. 1 or 2 -celled; 1 or 2 -seeded.

L. foliis petiolatis lanceolatis proliferis.

L. Leaves on leaf-stalks, spear-shaped.

IVY-LEAVED DUCK-WEED. Ditches and stagnant watirs. Soutbwell Hop-yard ; Newark Old Trent Ditches. A. June.

L. foliis sessilibus urinque planiusculis, ra- minor: dicibus solitariis.

L. Leaves sitting, hemispherical underneath: roots solitary.

LESSER DUCK-WEED. Ditches and poinds.

A. dune, July.

L. foliis sessilibus, radicibus confertis.

L. Leaves sitting: roots crowded.

trisulce. 
286 MONOECIA. TRIANDRIA: Typha;

GREATEF DUCK-WEED. Ditches and slow waters.

Ditches in Nottingham hieadow.

A. July, Aug.

\section{TRIANDRIA.}

TYPHA. Smith. 959. With.111.

Masc. Amenum cylindraceum, pilosum. Ato thera subternze, in filamentu communi.

Fam. Ament. cylindraceum, Sem. unicum, pedicello papporso.

Catkin cylindrical. Bloss, none.

M. Cal. 3 bristle-shaped leaves.

I. Florets on the same plant below the males. Cal soft hairs. Seed 1, standing on a fine brisile.

batifo. T. foliis subensiformibus, spica mascula $\mathrm{fx}_{\text {, }}$ ha. mineaque approximatus.

T. Leaves somewhat sword-shaped: spike will the male and female florets near logether.

GREAT CAT'S TAHL, or REND-MACE. Banks of rivers, fish-ponds, and marshes. Kirklington lawn; Clipstone Waters, a pond betwcen Little Carlton abd, the road into the fields near Wernhan Woods.

P. July.

SPARGANIUM. Smilh. 951. With. 112

Masc. Cal. triphyllus. Cor. nulla.

Frem. Cal. triphyllus. Cor. nulla. Drupe exsucca, monosperma. 


\section{MONOECIA. TRIANDRIA. Carex.. 28\%}

Flowers crowded into a globular form: male and female on the same plant.

Male. Cal. 3 leaved.

Fem. Cal. 6-leaved. Summits 1 or 2: Fruit a juiceless Drupa, superiour, of 1 cell, and 1 or 2 seeds.

S. foliis basi triquetris lateribùs concavis, pe- ramodunculo communi ramoso, stigmate lineari. sum.

S. Leaves triangular at the base, the sides concave. fruit stalks branched.

BRANCHED BUR REED. Ditches, marshes, hanks of river, monds. Ditches on the Kelham lsoad beyond Newark Bridge; River Deron, Markham Bidge; Newark.

P. July, August.

S. foliis basi triquetris lateribus planis, pe-simplex. dunculo communi simplici, stigmate linéari.

S. Leaves triangular at the base, the sides flat: fruit stalks unbranched.

UNBRA VCHED UPRIAHT RUR-REED. Marahy places, sides of pools, and ditches. The left-hand Ditch heyond Vewark Bridge on the Kelinem Poad, wilh s. Rumosum; Drains of a Close near Ollerton Bridse; Gamston Meadow, near \ottingham; and a fond near Oxton Wood; Thurgarton Lake P. July, Aug.

CAREX. Smth. 963. With. 81.

Masc. Amentum imbricatum. Cal. gluma uni- valvis. Cor. nulla.

Fæm. Ament. imbricatum. Cal. gluma univalvis. Cor. nulla. Stigmata 2 vel 3. Semen. arillo ventricoso tecium. 
288 MONOECIA. TRIANDRIA. Carex.

Catkins tiled. Cal. 1 leaf. Bloss none. Female flurets on the same piant with the male. Capsule inflated; entzre or 2-10oihed at the end. Stammit, 2, or 3. Seed 1, cornered, wathin the nectary (or capsule.)

* Spica unica, simplici.

1 Sprke single, not branched.

aioica. C. spica simplici dioica, fructibus ovatis nervosis adscendentibus márgine serrulatis.

C. Spike simple: edges of the capsule finely serrated: male ana female florets on different plants.

COHMON SEYPATE-MEADED CAREX. TuR bogs. Exisngley Hoor; (3xton Bottoms.

1’. May, June.

pulica. C. spica simplici androgyna: superne mas-

ris. cula, fructibus divaricatis retroflexis utrinque acuminatis, stigmatibus binis.

C. Spike simple, with $M$. and $F$. florets: $M$. flowers uppermost: capsules diverging, bent back, tapering at each end.

FLEA CAREX. Turfy and muddy bogs. Erlingley Noor. P: Jule.

* Spica composita, androgyna.

2. Spike compound, with both male and female florets.

stellula-C. spiculis subternis remotis, fructibus dita. vergentibus acuminatis ore integris.

C. Spikets generally 3, (or 4) distant: capsules diverging, entire at the $r \mathrm{~m}$, acute. 


\section{MONOECIA. TRIANDRIA. Carex. 289}

LITTLE PRICKLY CAREX. Sides of wet ditches, and marshy places. Oxton Bottoms; Edingley Moor.

P. May, June.

C. spiculis subsenis ovalibus approximatis al-ovalis. ternis, glumis lanceolatis arillum æquantibus.

C. Spikets about 6, oval, alternate, near together: scales spear-shaped, acute, as long as. the capsule.

OVAI,-SPIKED CAREX. Marshes and watery places; conmion.

P. Juнe.

C. spiculis solitariis remotis subsessilibus, remota. bracteis longissimis culmum superantibus, arillo subintegro.

C. Spikets axillary, solitary, distant, nearly sitiing: floral.leaf verylong: capsules undrvided at the end.

RMHOTE CAPEX. Moist woods, and sides of wet ditches. 1.perstone Wood. P. May, June.

C. spiculis congestis spicatis : infimis termi-intermenalique famineis: intermediis masculis, dia. culmo triquetro erecto.

C. Spike oblong, blunt: spikets many, the upper and lower ones female, the miadle ones male: straw upright.

SOFT BROWN CAREX. Niarshes and hogry meatows. Ethingley intor.

P. May, June.

C. spica supradecomposita coarctata obtusa, vulpine. fructibus diver gentibus, glumis acuminatis, culmi angulis compressis acutissimis.

C c 
29० MONOECIA: TRIANDRIA. Carex:

C. Spike more than doubly compound, compact, though branched, blunt: spikets male at the top: capsules diverging: straws with very acute angles.

GREAT-SPIKED CAREX. Marshes and banks of rivers; common. Oxton Bottoms. P. May.

panicu-C. spica supradecomposita paniculato-ramolata. sa acuta interrupta, fructibus patcntibus acuminatis, culmo acute triquetro.

C. Spike (or branchea panicle) more than doub. ly compound, acute: branches alternate, rather distant: capsules expanding : straw 3corned.

GREAT PANICLED CAREX. Bogs and watery places. Banks of the river Greet. P. June.

sylvati-C. vaginis pedunculo duplo brevioribus, spica. cis filiformibus laxiusculis nutantibus, fructibus ovatis triquetris rostratis.

C. Sheaths short: spikes thread-shaped, lim. ber, pendent: capsules egg-shaped, ending in an awn-like beak.

PENDULOUS WOOD CAREX. Woots; common. Oxton Wood.

P. May, June.

palles. C. vaginis brevissimis, spicis cylindricis pecens. dunculatis : fructiferis pendulis, fructibus ellipticis inflatis obtusis.

C. Sheaths extremely short, fem. spikes rather cylindrical, pendent when in fruit: capsules oblong, blunt.

ALE CAREX. Moist meadows and pastures; common.

P. May, June. 


\section{MONOECIA. TRIANDRIA. Carex. 291}

C. vaginis abbreviatis pedunculo sub-æquali- fava.:. bus. spicis fæmineis subrotundis, fructibus routratis arcuato deflexis, culno læviusculo.

C. Sheaths short, inclinsing nearly all the fruitstalk: the apper leaf loke part diverging, $M$ : spike strup shaped: F. spike roundish: capsules beak-pointed.

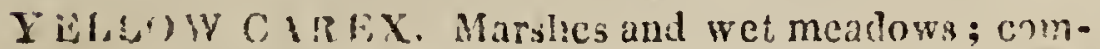
mon. Ediagley Moor. P. May, June.

C. vaginis abbreviatis pedunculo sub æqua- pracox. libus, spicis ovatis approximatis, glumis mucronulatis, fructibus subrotundis pubescentibus.

C. Sheaths short, inclosing nearly all the fruitstalk: spikes near together: male-spike clubshaped: fem. egg-shaped: capsules roundish, pubescent.

VERNAL CAREX. On wettish heaths, and poor soiled meadows. Elingicy Moor. P. April.

C. vaginis nullis, spicis fæmincis sessilibus pilulifeconfertis subrotundis, glumis mucronula- ra. tis, fructibus subrotundis villossis.

C. Sheaths none: male-spike slender, females somewhat globular, sitting, crowded: strazu feeble.

ROUND.HEADED CAREX. Moist heaths and pastures; not uncoumon. P. April, May.

C. vaginis elongatis pedunculo subdimidio panicea. brevioribus, spicis tæmineis laxiusculis re. motis, fructibus inflatis, culmo lavi.

\section{$\mathrm{C} \times 2$}


292 MONOECIA. TRIANDRIA. Carex.

C. Lower sheath inclosing about half the fruitstalk, upper ones nearly the whole: spikes slender, upright, far asunder: capsules inflated, bluntish, rather distant.

PINK-LFAVED CAREX. Hioist meadows and pagtures; fi equent.

P. May, sune.

recur- C. vaginis abbreviatis, spicis fæmineis cylinva. dricis pendulis, fructibus elliptico-triquetris scabriusculis, radice repente:

C. Sheaths short: fem. spikes nearly cylindrical, pendent: capsules roundish egg-shaped: roots creeping.

GLAUCOUS HEATH CAREX. Moist meadows, pastures, heaths, and woods; very common.

P. May, Jure.

caspi- C. digyna, vaginis nullis, spicis sessilibus tosa. cylindricis obtusis, bracteis auriculatis, fructibus persistentibus.

C. Summits 2: sheaths none: spikes nearly sitting and cylindrical, blunt: leaves upright, soft.

TUFTF,-BOG CAREX. Marshes and wet wonds; very common.

P. May.

*** Spicis sexu distinctis : masculis plu. ribus.

4 Spikes male and female: male spikes 2 or more.

acuta. C. digyna, spicis filiformibus: florentibus cernuis : fructiferis erectis, fructibus ellip. ticis obtusis apice indivisis. 


\section{MONOECIA. TRIANDRIA. Carex. 298}

C. Summits 2: spikes thread-shrped; fem. sprkes nodding whilst in flower, upright when ripe: capsules rather acule, entrre at the end.

SLFVI)FR-GPIKED CAREX. Fdges of rivers, pouds and ditches; and also in meadows. Banks of the river sireet.

P. May.

C. spicis cylindricis obtusiusculis erectis, glu- paludomis.faminearum aristatis; mascularum ob. sa. tusis, fructubus ellipticis emarginatis.

C. Sprkes oblong, bluntish: scales of the males blint. of the female spear-shaped: capsules egg.spear shaped, stightly toothed at the end.

LESSER COMAON CAREX. Mawhes and banks of wet ditches, ofien fotud with C. riparia. WIrF. Banks of the Greet.

P. May.

C. spicis erectis : masculis triquetris : fami-riparia. neis cylindricus, gimnis omnbus acumina. tis, frucubus rusiratis bifurcis.

C. Spikes oblong, acute: scales of the male spear-shaped of the femule tapering to an ailn-iike point: capsules ggg-spear-shaped. cloven 2 nio 2 terth at the ena.

GRI:A CMManO CARFX. Fdges of rivers, ponds and dicies. Banks of the river Giret.

P. April, May.

C. spicis fremineis cylindricis elong is sub-ampullasesuliibus, viginis nullis, fiucribus inflatis cra. rosiro linearı bafurco.

C. Spzkes throad shoped, the males thinnest, jomalios cylindrical. upright: capsules inflaled, glovular, awn-vertied, ázvirging.

C c 3 


\section{MONOECIA. TETANDRIA. Betula.}

SLENDER-BEAKED BLADDER CAREX. Pogs and marshy watery places; but not very common. Near the Cotton Mill, Southwell.

P. May.

hirta. C. pilosa, spicis abbreviatis cylindricis remotis, vaginis pedunculo subæqualibús, glumis aristatis, fructibus hirtis.

C. Hairy: all the spikes oblong; female spikes far asunder, sheathed: capsules hairy.

HA IR Y CAREX. Mearlows and pastures, in wet or máshy places. Soutbwell.

P. May, June.

\section{TETRANDRIA}

BETULA. Smith 1011. With 206.

Masc. Cal. amenti squama monophylla, trifida, triflura. Cor. quadripartita.

Fem. Cal. amenti squama monophylla, subtrifida, biflora Styliduo. Semina compressa. Male and female flowers on the same plant. Cal. 1 leaf, with 3 or 5 clefts. Bloss. with 4 divisions.

Male Cal. 3-flowered.

Fem. Cal. 2. flowered. Seeds 2 or 3 .

elba. B. foliis ovat is acutis serratis glabriusculis.

B. Leaves trianguiar-spear-shaped, acule, smoosh, doubly serrated.

COMmoN BIRCH. Wonds and moist hedges. Newark; Soutbwell; Manslield. T. A pril, May.

$$
\therefore 3
$$


B. pedunculis ramosis, foliis subrotundo-cu- Almuss neiformibus repandis serrat is glutinosis: $\mathrm{dx}$ ill is venarum subtus villosis.

B. Fruit-stalks branched, wedge-shaped, very blunt: leaves roundish, glutinous: verns underneath, woolly at the base.

COMMON ALDER. NEAR WATER. Coddington; Newark; Southwell. T. March.

BUXUS. Smith. 1013. With. 210.

Masc Cal. triphyllus. Pet. 2. Germinis rudimentum.

Fæm. Cal. tetraphyllus. Pet. 3. Styli 3 . Caps. trirostris, trilocularis. Sem. 2.

Male and Female flowers on the same or on a different plant.

Male Caly x 3 leaved. Bloss. 2 petals. Germen only a rudzment.

Female Calyx 4 lraved. Bloss 3 petals. Caps. 3 celled, 3 -beaked. Seeds 2.

\section{BUXUS.}

B. sempervirens. LINN. With.

BOX-CREE. Woods and hedges, in a calcareous soil.

S. A pril.

URTICA. Smith. 1014. With. 201.

Masc. Cal. tetraphyllus. Cor. nulla. Germinis rudiment um cyathiforme.

Fxm. Cal diphyllus. Cor. nulla. Semen $\mathbf{1}_{2}$ superum, nitidum.

Flowers male and female apart. Caly x 4 -leaved. Bloss none. 
296 MONOECIA. PENTANDRIA. Bryonia.

Male, Nectary in the centre; glass-shaped. Fem. Cal. 2, opposite leafits very small. Sum. mit harry. Seed 1, egg-shaped, shining.

urens. U. folliis oppositis ellipt cis subquinquenervibus, racemis subsimplicibus.

U. Leaves oppoizte, oval: stem branched.

SMALL NETTLE. Rubbish, cultivated ground; very common.

A. June--octoher.

dioica. U. foliis oppositis cordatis, racemis ramo. sissimis geminis subdioicis.

U. Leaves opposile, heart-shaped: bunches in pairs.

GRSAT NETTLE. Ditch banks, and amongst rubbish; commoll.

P. July, August.r

\section{$\checkmark$ PENTANDRIA.}

BRYONIA. Smith. 1018. With. 67.

Mis. Cal 5-dentatus. Cor. 5-fidd. Filam. 3 . Anth. 5 .

Fæm. Cal. 5.dentatus. Cor. 5.fida. Stylus 3-fidus. Bacca infera, subglubosa, polysperma.

Cal. 5 toothed. Bloss, with 5 divisions. Male, Anthers united at the hase.

Fem. Style 3 cleft. Berry roundish, mostly 1 seeded.

dioica. B. foliis palmans wa rue calloso scabris, tlo. ribus divicis. 
MONOECIÀ. POLYAND. Myriophyllum. 297

B. Leaves hand-shaped; rough on both sides, with callous points: male and female flower's on different plants.

RSD-BERRITD BRIONY. Hcdges and Thickets; common. Newark; Solthweil. P. Mayo--Sept.

\section{POLYANDRIA.}

CERATOPHYLLUM. Smith. 1020. With. $44^{\circ}$.

Masc. Cal. multipartitus. Cor. nulla. Stam: $16-20$.

Fem. Cal. mulcipartitus. Cor. nulla. Stigma subsessile. Sem.1, corticatum.

Male and fem. flowers on the same plant. Cal. with many divisions. Bloss. none.

Male Stamens twice as many as the segments of the calyx.

Fem. Style none. Nut coa'ed, without valves.

C. fructibus trispinosis.

demer.

C. Leaves forked, toothed; lower ones strap- sum. shaped: upper ones much croisded, tubular and inflated, beaks of the capsule of equal length.

COMMON HORNWORT. Ditches and slow streams; not very common. Winkburn.

P. September.

MYRIOPHYLLUM. Smith.1021. With. 389 . 
Masc. Cal. tetraphyllus. Pet. 4. Stam. 8.

Fæm. Cal. tetraphyllus. Pet. 4. Sizgmata 4 . sessilia. Sem. 4, corticata.

Male and female flowers frequently on the same plant. Cal. 1 leaf, 4 toothed. Petais 4 , with claws; soon falling off. Styles none. Nuts. 2 or 4 , covered with a coat.

spica- M. floribus interrupte spicatis aphyllis.

ium. M. Spikes interrupted, leafless.

SPIKED WATER-MILLFOIL. Ditches, ponts, lakes and still water. Old Trent Ditches beyond Newark Bridge, on the Kelham road. P. July, Aug.

verticil. M. floribus omnibus axillaribus.

latum. M. Flowers in leafy whirls.

VERTICILLATE WATIR-MILLFOIL. Ditches and stagnant waters. In the Trent belo iv Colwick, on the opposite side of the river. DEEKING.

P. July, August.

SAGITTARIA: Smith. 1023. With.

Masc. Cal. tiphyllus. Pet. 3. S amina fere 24. Fæm. Cal. triphyllus. Pet. 3. Pastilla plu. rima. Caps. plurimæ, ventricusæ, munus. permæ.

Stam. and Pist. in different flowers on the same plant. Cal. 3 leaves. Bloss 3 petals.

Male. Filam about 24 .

Fem. Seeds many, naked.

sagitti. S. foliis sagittatis acutis.

folia. S. Leaves arrow-shaped, acute.

COMMON IRROW-HEA D. Ditchesand banks of slow rivers. Left hand ditches heyond ivewark bridge, on the Keliam Road; ditches in Nottingham Meadow; dita 
ches in Gamstone Meadows; about Markham Bridge, vear the Spring Gardens, Newark. P. July, August.

\section{ARUM. Smith. 1023. With. 497.}

Spatha monophylla, basi convoluta. Spadix cylindricus, androgynus, supra nudus, medio staminiferus, basi germiniferus. Baccae uniloculares.

Sheath a leaf, cone-shaped. Fruit-st. naked above, bearing germens at its bottom, and stamens in the maddle.

A acaule, foliis hastatis integerrimis, spadice macula. clavato obtuso.

tuin.

A. Leaves halberd.shaped, very entire: spike stalk ilub-shaped.

CUCKOO POINT. WAKE ROBIN. Shady places ditch banks, and rough grouuds, particularly in a clityey soil ; requent.

P. May.

POTERIUM. Smith. 1025. With. 493. Masc. Cal. triphyllus. Cor. quadripartita. Stam. 30-40.

Fæin. Cal. triphyllus. Cor. quadripartita. Pist. 1, sive 2. Nux bilocularis, tubo corolly indurato corticata.

Stamens and pistils in different flowers. on the same plant. Calyx 4 leaves. Bloss. with 4 divesions.

Male Stam. 301040.

Fem. Drupajuiceless; beneath; 1 or 2 celled; formed of the indurated tube of the blossomi.

P. inerme caulibus subangulosis.

P. Thornless: stems somewhat anguiar.

Sanguisorba.

D d 
300 MONOECIA. POLYANDRIA. Quercus.

COMMON BURNET. In a dry calcareous soil. Thorney Moor Holt, und Greet Neadows, Southwell.

P. July.

QUERCUS. Smith. 1025. With. 387.

Masc. Cal. carapanulatus, lobatus. Cor. nulla. Stam. 5-10.

Fæm. Cal. campanulatus, integerrimus, scaber Cor. nulla. Stylus 1. Sttgmala 3. Nux supera, coriacea, monosperma.

Male and female flowers on the same plant. Bloss. none.

Male Calyx 5-cleft. Stamens from 5 to 10 :

Fem. Cal. 1 leaf very entire, rough. Styles from 2. to 5. Nut egg-shaped, leather-like, of 1 seed, and when ripe, of 1 cell.

Robur. Q. foliis deciduis oblongis superne laterioribus sinubus acutioribus: angulis obtusis, pedunculis fructiferis elongatis.

Q. Leaves on leaf-stalks, oblong, broadest towards the end, indentations rather acule, angles blunt: fruit nearly sitting.

COMMON BRITISH OAK. Woods and hedges. The Grees Ditr $O$ at Wropeck, the seat of the DukF of yortusin, has long been justly regardad as a llaturil curiusity.

I. April.

FAGUS. mith. 1027. With. 443.

Masc. Cal. campanulatus, quinquefidus. Cor. nulla. Siım. 5-12.

Fæm. Cal. quardrifidus. Cor. nulla. Styli $2-3$. trifidi. Sem. 2 vel 3 , calyce coriaceo, muricato, tecta. 


\section{MONOECIA. POLYANDRIA. Carpinus. 301}

Male and female fowers on the same-plant.

Bluss. none.

Male Calyx 5 cleft; bell-shaped.

Fem. Calyx with 4 teeth, changing into a prickly 4 -valued, 2-seeded capsule.

F. follis lanceolat is acuminato-serratis subtus Castanutis, acule is fructus compositis implexis. nea.

F. Leaves spear-shaped, with tapering serratures, naked underneath.

CMLSVI TREE. Wools and hedges. T. May.

F. foliis ovatis obsolete serratis, aculeis fruc- sylzatus simplicibus. tica.

F. Leaves egg-shaped; indistinctly serrated.

BEECH TREE. Woods and hedges in a calcareous soil.

T. March, April.

CARPINUS. Smith. 1029. With. $44^{2}$.

Masc. Cal. amenti squama subrotunda. Cor. nulla. Stam. 8-20.

Fæm. Cal. amenti squama oblonga. Cor. nulla. Germina 2. Styli singulis 2. Nux angulosa, unilocularis.

Male and female flowers on the same plant.

Bloss. none. Cal. 1 leaf, a fringed scale:

Male. Stamens 18 or 20.

Fem. Germens 2, with a styles on each. Nut. egg-shaped.

C. squamis strobilorum planis oblongis denta. Betus tis.

lus.

C. Scales of the cones flat. 
302 MONOECIA. MONADELPHIA. Corylus.

HORN-BEAM. In woods and hedges. T. May. CORYLUS. Smith. 1030. With. 378 . Masc. Cal. amenti squama trifida. Cor. nulla. Stam. 8.

Fæm. Cal. bifidus, lacer. Cor. nulla. Stylí 2: Nux. ovata, lævis, unilocularis, calyce ventricoso, coriaceo, tecta.

Male and female flowers on the same plant. Bloss. none.

Male, Cal. 1 leaf, a cleft, resembling a scale, containing 1 flower.

Fem. Cal. 2-leaved, ragged. Nut egg-shaped. fuella- C. stipulis ovatis obtusis, folliis subrotundis na. cordatis acuminatis, ramulis pilosis.

C. Stipula spear-shaped: twigs hairy.

IAREL-NUT TREE. Woods and hedges; common. 1. March, April.

\section{MONADELPHIA.}

PINUS, Smith. 1031. With.615.

Masc. Cal. amenti squama peltata. Cor. nulla. Anthera squamis adnata, sessiles.

Fæm. Cal. amenti squama biflord. Cor. nulla. N'ux unilocularis, alata.

Male and fem. flowers on the same plant. Bloss. none.

Male Calyx scales forming abud slanding open. Anthers naked. 
MONOECIA. MONADELPHIA. Pinus. 303

Fem. Calyx scales forming a cone, 2 flowers in each scale. Pisil 1. Nut of 1 cell, without valves, bordered with a membrane.

P. foliis geminis rigidis, strobilis junioribus sylvespedunculatis recurvis, antherarum cristaex - tris. igua.

P. Leaves in pairs, rigid: cones egg-conical, mostly in pairs, as long as the leaves: scales oblong, blunt.

SCOTCH FIR. Woods, coppices, plantations.

T. May.

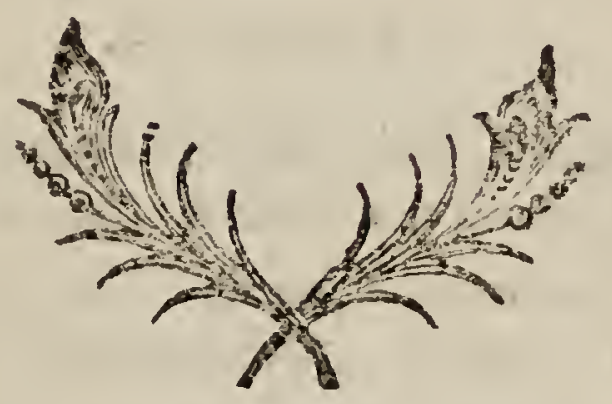

D d 3 


\section{Classis XXII.}

\section{DIOECIA.}

Flores masculi et frminei in diversis plantis.

\section{MONANDRIA.}

\section{Stamen 1.}

Salix purparea et Hei.

\section{DIANDRIA.}

Stamina 2.

SALIX. Masc. Cal. amenti squama. Cor. nulla: Glandula baseos nectarifera. Stam. 1-5.

Fæm. Cal. amenti squama Cor. nulla. Stigmata. 2. Caps. supera, unilocularis, bivalvis. Sem. papposa.

M. Cal. scale of a catkin. Bloss. none.

F. Summits 2. Caps. 2-valved. Seeds downy.

\section{TRIANDRIA.}

Stamina 3 .

EMPETRUM: Masc. Cal. tripartitus, $P_{\text {et. }}$ 3. Stam. capillaria, 3-9. 
Fæm. Cal. tripartitus. Pet. 3. Stigmala 9. Bacca supera, elineasperma,

EMPETRUM. Male and female flozers on distinct plants. Cal. with 3 divisions Bloss. 3 petals.

M. Slamens long.

F. Berry with 9 seeds.

RUSCUS. Masc. Cal. hexaphyllus. Cor, nulla. Nectarium ovatum, tubulosun, infus stameniferum. Fxm. Cal. Cor. et Nect. maris. Stam. nulla. Stylus 1. Bacca supera, trilocularis. Sem. gemina. RUSCUS. Stam. and pisil in separate fluwers. Bloss. none. Nectary central, egg-shaped, open at the top.

\section{TETRANDRIA.}

\section{Stamina 4 .}

MXRiCA. Mas. Cal. amenti squama concava. Cor. nulla.

Fæm. Cal. amenti squama concava. Cor. nulla: Styli 2. Bacca monosperma.

MYRICA. Flowers male and female on the same or on distinct piants. Catkins scales crescent-shaped. Bloss. none.

F. Berry with 1 seed.

VISCUM: Masc. Cal. nullus. Pet. 4. basi dilatata, connata, calycina. Antherce sessiles, petalis adnatz. Fxm. Cal. submarginatus. Pet. 4, basi dilatata. $S t y$. lus nullus. Bacca infera monosperma. 


\section{DIOECIA. PENTANDRIA.}

VISCUM. Flowers Male and female on distinct plants.

M. Cal. with 4 divisions. Anthers fixed to the calyx without any intervening filaments.

\section{PENTANDRIA.}

Stamina 5 .

HUMULUS. Masc. Cal. pentaphyllus. Cor. nulla. Anth. apice biporosæ.

Fæm. Cal. amenti squama obliqua, integra. Cor. nulla. Styli 2. Semen 1. tunicatum, calyce alatum.

HUMULUS. Seed 1, within a leafv calyx. Flowers male and female on different piants.

M. Cal. 5 leaved.

F. Cal. I leaf, entire; with an oblique opening.

\section{HEXANDRIA.}

Stamina 6.

TAMUS. Masc. Cal. sexpartitus. Cor. nulla:

Fæm. Cal. sexpartitus. Cor. nulla. Stylus trifidus. Bacca infara. trilocularis. Sem. bina.

TAMUS. Flowers male and female on distinct plants. Caly $x$ with 6 diviszons.

F. Style 3-cleft. Berry 3-celled: beneath. Seeds 2. 


\section{OCTANDRIA.}

Stamina 8.

POPULUS. Masc. Cal. amenti squama lacera. Cor. tuŕbinata, obliqua, integra.

Fxm. Cal. amenti squama lacera. Cor. turbinata, integra. Stignata 4. Caps. supera, bilocularis, bivalvis. Sem. papposa.

POPULUS. Flouters in Catkins; $M$. and $F$. on dis. tinct plants. Cal. a ragged scale of the catkin. Bioss. turban-shaped; oblique; entire.

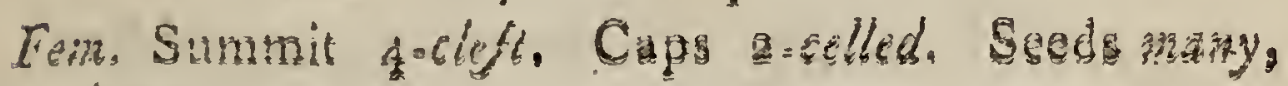
downy.

\section{ENNEANDRIA.}

\section{Stamina 9 .}

MERCURialis. Masc. Cal. taipartitus, Cor. nulla. Stam. 9-12. Anil. globosx, didymx. Fxm. Cal. tripartitus. Cor nulia. Styli 2. Caps. dicocca, bilocularis. Serm, solitaria.

MLRCURIALIS. Flowers male and female on dis.tinct plants. Cal, with 3 divisions. Bloss. none. M. Stam. 9 to 12. Anthers globular; double. I. Caps. 2. united; each with 1 cell and 1 seed. 
308 DIOECIA. MONADELPhIA. Salix.

HYDroCharis. Masc. Cal. trifidus. Pet. 3. Filamenta tria interiora appendiculata.

Fæm. Cal. trifidus. Pet. 3. Styli 6. Caps, sexlocularis, polysperma, infera.

HYDROCHARIS. Flowers male and female on distinct plants. Cal. 3.cleft. Bluss. 3 petals.

$M$. Sheath 2.leaved. Filaments, the inner ones bearing a kind of style.

F. Caps. 6-celled; many-seeded; beneaih.

\section{MONADELPHIA.}

Filamenta inferne in unum corpus coalita.

JUNIPERUS. Masc. Cal. amenti squamæ. Cor. nulla. Stain. 3 .

Fæm. Cal. amenti sqamæ pauciores, demum carnosæ, coalitæ in baccam. trispermam.

JUNIPERUS. M. and Fem. flowers on different. plants.

M. Cal. a catkin. Bloss. none.

F. Col. with 3 divisions. Bloss. 3 petals. Styles 3. Berry beneath: 3 -seeded: the cup at the base.

\section{DIOECIA. \\ I DIANDRIA。}

SALIX. Smith. 1e39. With. 45. 
Masc. Cal. amenti squama. Cor. nulla. Glandula bascos nectarile:a. Stam. 1-5.

Fæm. Cal. amenti squama. Cor. nulla. Stigmata duo. Caps. supera, unilocularis, bivalvis. Sem. pápposa.

Catkin each scale containing 1 flower. Bloss. none.

Male. A nectarifcrous gland at the bottom of the flower.

Female. Stule cloven. Caps. 1.cell: 2 values. Seeds dozony.

* Foliis serratis glabriusculis.

1. Leaves smooth serrated.

3. Monandra erecta, foliis lanceolat is acumi- Helix. natis serrulatis glabris, stylo elungato filiformi, stigmatibus linearibus.

S. Leaves strap-spear-shaped: upper leaves oblique; catkins downy; flowers with 1 - stamen.

Salix monandra. With. 45:

RUSR WIILOW. Hedre; watery plares, and sides of rivers, osier beds. P'irks at Southwell

s. March, April.

S. triandra, foliis lineari-oblongis serratis trianglabris, germinibus pediccllatis.

dia.

S. Lenves oblung-spear-shaped: flowers with 3 stamens. Lisin. sometzmes. Hicos.

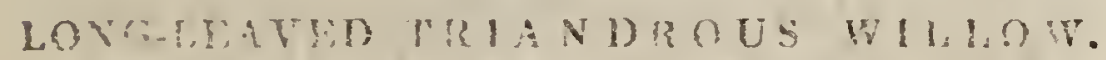
Woot? bedges, und bants of rivers souhwell Water liil.

E. or T. March - A ugust. 


\section{DIOECIA. DIANDRIA. Salix.}

fragilis. S. folits lanceolatis acuminatis undique serratis glaberimis, petiolis dentato-glandulosis, nectario inusculinorum gemino.

S Leaves egg-spear-shaped: leaf-stalks toothed with glinds.

CRACK-WLLOW. Woods, hedges, and banks of rivers.

'T. April, May.

* * Tolís villosis.

2 Leaves very entire, wocily.

arenaria. S. follis subintegentimis ovatis acutis: supra subvillosis; subus densisime lunatis.

S. Leaveshairy, spear shaped.

Sulix lapponum. With 5 :

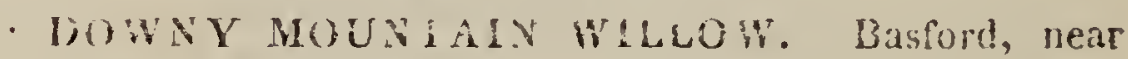
Nottiagiam.

s. june.

aguatica. S. foliis subseratis cbovato-ellipticis pubescentibus planis: subtus glaucescentibus, stipulis rotundatis dentatis.

S. Leaves oblong-egg-shaped, somewhat woolly underneaits: slipula half-heart-shaped.

Salix cinerea. -Wich. 54.

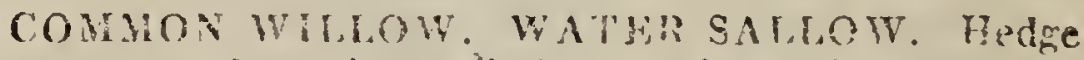
rows, hanks of riser, filciles, and in wouls; rem comnud. Nevaris; southwall. S. April.

caprea. S. folins ovatis acuminatis serratis unduldt is: subtus tonentosis, stiptilis sublunatis, capsulis vemericosis.

S. Leaves eg:-shaped, wrinkled, coitony underneath, waved, lovthed toward's the end.

GREAT ROUND-LEA IED SALLOW. Woods and hetiges; common.

S. April. 


\section{BIOECIA. TRIANDRIA. Empetrum. 31}

S. folis lanceolato-oblongis acuminatis undu- acumilatis denticulatis: subtus tomentosis, stipu- nata: lis reniformibus, capsulis ovato-subulatis.

S. Leaves egg.oblong, cottony underneath; upper ones entire, lower ones scolloped.

LONG-LEAVED SALLOW. Thickets and wet places. S. $A$ pril.

S. foliis lanceolato-linearibus longissimis acu-vimina. minat is incegerrimis subtus sericeis, ramis lis. virgatis, stylo elongato.

S. Leaves spear-strap-shaped, very long, acute, silky underneath: branches rod-like.

COMHON O-IER. Willow beds, woods and hedges; conmon. Newark; Southwell. S. April, May.

S. foliis lanccolatis acuminatis serratis utrin- alba. que sericeis; serraturis infimis glandulosis, stigmatibus bitartitis.

S. Leaves spear-shaped, tapering to a point, serrated, doziny on both sides: the lowermost serratures glandular.

COMMON WHITE WILLOW. Woods, hedge-rows, wet meadows and pasture laud; common.

\section{TRIANDRIA.}

EMPETRUM. Smith. 1072. With. 176. Masc. Cal. tripartitus. Pet. 3. Stam. ca. pillaria, $3-9$.

E e 
Fæm. Cal. tripartitus. Pet. 3. Stigmata 9.

Bacca supera, enneaiperma.

$\mathrm{M}$ and $\mathrm{F}$. flowers on separaie plants. Calyx with 3 divisions. Bliss. 3 petals.

Male. Stam. long. Fem. Berry with g seeds. nigrum. E. caulibus procumbentibus.

E. Stems trailing.

BLACK CROW, or CRAKE-BERRY. Heaths, both in the driest and most barren rocky soils; not very comnion. Sherwood Foresi, near Hansfield.

S. May.

\section{TETRANDRIA.}

VISCUM. Smith. 1074 Whth, 203.

Masc. Cal. nullus. Pet. 4. basi dilatata, con-

nata, calycina. Antinerce sessiles, petalis adnatæ.

Fæm. Cal suhmarginatus. Pet. 4, basi dilatata. Stylus uulius. Lacca infera, monosperma.

Male and female flowers on different plants. Blinss. none

Male Calys with 4 diznsions. Filam. none. Anthers fixed to the calyx.

Fem. Calyx 4 leaves. superiour. Style none. Berry pulpr; 1-cellea; 1-seeded. Seed heartish iped.

album. V. foliis lancenlatis obtusis, caule dichotomo, capitulis axillaribus. 
DIOECIA. PENTANDRIA. Myrica. 313

V. Leaves spear-shaped, blunt: slem forked: spizes axillary.

MISsEl.TOE. Mostly on appletees: also on the pear, hawthorn, oak, hazel. Orchards at Halium, neir Southwell.

S. Mỉà.

MYRICA. Smith. 1076. With. 208.

Masc. Cal. amenti squama concava. Cor. nulla.

Exm. Cal. amenti squama concava. Cor. nulla. Styli 2. Bacca monosperma:

Flowers in catkins, on different plants. Cal. 2 leaves. Bloss. none.

Fem. Drupa 1-celled, superiour. Seed 1.

M. foliis lanceolatis subserratis, caule fruc- Gale. ticoso.

M. Leaves spear-shaped; somewhat serrated; stem shrub-like.

SWEET GALE. DUTCII MYRTLE. On hogs, in gravelly soils. Sutton Wood, sear Retford. Dr. MAson.

\section{PENTANDRIA.}

HUMULUS. Smith. 1077. With. 277.

Masc. Cal. pentaphyllus. Cor. nulla. Anth: apice biporosæ.

Fxm. Cal. amenti squama obliqua, integra: Cor. nulla. Styli 2. Semen unicum, tunicatum.

Eca 


\section{DIOECIA. HEXANDRIA. Tamus.}

Mile and female flowers on different plants. Bloss. none.

Male. Calyx 5-leaved.

Female. Calyx i-leaved, with a slanting opening, entzre. Seed 1, walhin a leat.like calyx. Lupulus. HUMULUS.

HOP. In hedges. Cultivated in the North Clay's; Southwell; Ollerton; and other parts of the County. P. July.

\section{v HEXANDRIA.}

TAMUS. Smith. 1078. With. 344.

Masc. Cal. sexpartitus. Cor. nulla.

Fæm. Cal. sexpartitus. Cor. nulla. Stylus trifidus. Bacca infera, trilocularis. Sem. bina.

Flowers male and female on different plants. Calyx with 6 divisions. Bloss. none.

Fem. Style 3-cleft. Berry 3.celled; beneath. Seeds 2.

commu- $T$. foliis cordatis indivisis.

nis. T. Leaves heart-shaped: undivided.

BLACK BRYONY. Thickets and hedges; common. P. June.

\section{OCTANDRIA.}

POPULUS. Smith. 1079. With. 375.

Masc. Cal. amenti squama lacera. Cor. tur. binata, obliqua, integra. 
DIODECIA. ENNEANDRIA: Mercurialis. 315

Fæm. Cal. amenti squama lacera. Cor. tubinata, integra. Stigmata 4. Caps. supera, bilucularis, bivalvis. Sem. papposa.

Flowers male and female in catkins on distinct plants. Caly $\mathrm{x}$ scales ragged. Bloss. turban-shaped, mouth entire, slanting. Female Summit 4-cleft. Caps, 2.celled. Seeds many, downy.

P. foliis cordato-subrotundis lobatis dentatis alba. subrus tomentoso-niveis, amentis ovatis.

P. Leaves nearly triangular, toothed and angular; cottony underneath.

GREAT WHITE POPLAR. ABELE-TREE. MEdges, woods, and near brooks.

T. March. .

P. foliis suborbiculatis dentatis utrinque gla- treminbris, petiolis compressis, ramulis hirtis. la.

P. Leaves circular, toothed and angular, smooth on bolth sides.

ASP. AGPEN. TREMPIIVG POPLAR. Moist woods. and in boggy grotind.

T. March, April.

${ }^{y}$ foliis deltoidibus acuminatis serratis utrin- nigra. que glabris.

P. Leaves trowel-shaped. tapering to a point, serrated, smooth on both sides.

LLACK POPLAR. Near rivers and wet shady places.

T. Murch.

\section{ENNEANDRIA.}

MERCULIARIS. Smith. 1083 . With. $39^{2}$.

Masc. Cal. tripartitus. Cor. nulla. Siam. 9-12. Antherce globosa, didymx.

$$
\text { E e } 3
$$


Fan. Cal. tripartitus. Cor. nulla. Styli 2. Caps. dicocca, bilocularis. Sem. solitaria. Male and female flowers on different plants. Bloss. none. Calyx with 3 divisions.

Male Stamens from 9 to 12. Anthers globular, double.

Fem. Caps. double, 2-celled; 1 seed in each.

peren- M. caule simplicissimo, foliis scabris, radice nis. repente.

M. Stem undivided: leaves rough.

PFRENNIAL MFRCURY. Wools, hedre banks. Top of a close in Bcacon Field, near Mr. Millington's brick yard; thickets near Oxton 'T'ollbal ; Eppers'onc Woods.

P. April, May.

cznnua. M. caule brachiato, foliis glabris, floribus racemosis, radice fibrosa.

M. Stem branching : leaves smooth: flowers in spikes.

ANNUAL, MERCURY. Waste places and dinghills, about towns ard villages; not comm is in gardens; Newark, Southwell.

A. July, Sept.

HYDROCHARIS. Smith. 1084. Wish. 393.

Masc. Cal. trifidus: Fet. 3. Filamenta tria interiora appendiculata.

Fim. Cal. trifidus. Pet. 3. Styli 6. Caps. sexlocularis, polysperma, infera.

Male and female fiowers on aifferent planis. Cal. 3.clefi. Bloss. 3 petals.

Male. Sheath 2-leaved. Filaments, the 3 inner ones style-bearing. 


\section{DIOECIA: MONADELPHIA. Junipcrus. 317}

Fem. Caps. 6-celled; many-seeáed; beneath. HYDROCHARIS.

Morsus-

rana.

COMMON FROGBIT. Slow strezms and wet ditches. Ditches on the road to Kelham, beyond Newark Brilige, particularly abcut Fidler's Bridge, the foot-road to Kelham.

P. July.

\section{MONADELPHIA.}

JUNIPERUS. Smith. 1085. With. 599. Masc. Cal. amenti squamæ. Cor. nulla. Stam. 3.

Fæm. Cal. amenti squamæ pauciores, demum: carnosæ, coalitæ in baccam trispermam.

Male and female flowers distinct. Male. Cal. a scale of the catkin. Bloss. none. Fem. Cal. with 3 divisions. Petals 3. Pistils 3 . Drupa juicy, closed, 1.celled, many-seeded; with 3 tubercles formerly the calyx.

$\mathrm{J}$. foliis ternis patentibus mucronato-spinosis commubacca longioribus.

J. Leaves 3 together, expanding; sharp.pointed; longer than the berry.

COMMON JUNIPER. Heaths and commons; but not frequent.

S. May.

TAXUS. Smith. 1086. With. 614.

Masc. Cal. nuilus. Cor. nulla. Stam, plu. rima. Anth. peltaix, ostofidx. 


\section{DIOECIA. MONODELPHIA. Taxus.}

Fæm. Cal. urccolatus, integerrimus. Stylus nullus. Sem. 1, calyci baccato impositum. Male and female flowers on different plants. Bloss. none. Calyx a 4 or 7 -leaved bud.

Male. Anthers target-shaped, 8-cleft.

Fam. Style none. Sced 1, surrounded at the base by a pulpy receptacle; the upper half naked.

baccata. T. foliis approxinatis.

T. Leaves solitary strap. shaped, prickle pointed near together; receptacle of the male flowcrs somewhat globular.

YEW-TREE. Wonde and hedges. T. Narch, Aprik. 


\section{POLYGAMIA. \\ Classis XXIII. POLYGAMIA.}

Flores hermaphroditici et masculi aut fieminei, structura partium inter se diversi, in eadem specie.

\section{MONOECIA.}

Fl. hermaphr. et masc. aut facm, in eadem planta.

ATRIPLEX. Hermaphr. Cal. quinquepartitus, inferus. Cor. nulla. Siam. 5. Siylus bipartitus. Sem. 1, depressum.

Fæm. Cal. diphyllus. Cor, nuilla, Slylus bipartitus. Sem. 1, compressum.

ATRIPLEX. Seed 1 ; compressed. Female flow. ers on the same plant.

H. Cal. 5 leaves.

F. Cal. 2 leaves.

\section{MONOECIA.}

ATRIPLEX, Smith. 1090. With. 274. 
320 POLYGAMIA. MONOECIA. Atriplex.

Hermaphr. Cal. quinquepartitus, infèrus. - Cor. nulla. Stam. 5. Stylus bipartitus. Sem. 1, depressum.

Fæm. Cal. diphyllus. Cor. nulla. Stylus bipartitus. Sem. 1, compressum.

Bloss. none. Flowers some hermaphrodile: - others fem. on the same plant.

Hern. Calyo gleaved. Sced 1, depressed, uprighl,

Fem. Calyx 2-leaved. Seed 1, compressed. patula. A caule herbacen patulo, foliis deltoidcolanceolatis subhastatis, calycibus seminum discosubmuricatis.

A. Stem herbaccous: calyx values of the fe. male flowers large, trowel.shaped, indented. A. hastata. With. 274 .

SPIREAIING HALBFRD-IFAVFI) ORACH. On rublsish, dunghills, am in kitchen gardens; very common Newark; Southwell.

A. Juue-.-A A ugust.

ongzusti- A. caule herbaceo divaricato, foliis lanceolafolza. tis integerrimis, infimis subhastatis, calycibus seminum hasiatis leviusculis.

A. Stem herbaceous, spreading: leaves somewhat troulel-spear.shaped: calyx of the fruit toothed on the disc.

A. patula. With. 275 .

SPREADING NARROW-I.EAVED ORACH. On rublith, and ditch basks. Newark; Sonthwell; Mullsficld.

A. June---August. 


\section{Classis XXIV. \\ CRYPOGAMIA.}

Fructificatio anomala vel obscura.

\section{FILICES.}

Herba frondosa. Fructificatio vel dorsalis, vel terminalis, vel subradicalis.

Annuluta; capsulis annulo elastico, valvulis contrario, cinctis.

Capsules roundish, on pedacles encompassed by a jointedelastic ring; and opening irregularly into 2 parls.

POLYPODIUM. Frutificationes in punctis subrotundis sparsis. Intolucrum nullum.

POLYPODIUM. Capsules a'rsposed in distinct circular docs, on the unaer surface of the leuf.

ASPIDIUM. Fruclf ir punctis subrotundis, sparsis. Lnvol. umbilicatum.

ASPIDIUM. Fructifications scattered in rounaish dols. Invelucrum umbelicaled.

ASPLENIUM. Fiurlef. in lineolis sparsis. Invol. costam versus dehiscens. 
ASPLEN UM. Capsules disposed in straight and nearly parallel lines on the under surface of the leaf. SCOLOP! NDRIUM. Frutef. in lineolis giminis, intervenis. Intulucra sibi invicem incumbentia. SCOLOPLNI)RIUM. Fructif. in scattered double lines between veins. Invol. folding lengihways over one anotincr.

BLECHNUM. Fructif. in lineis continuis, costæadjacentubus. Invol. costam versus dehiscens. BLECHNUM. Capsules forming 2 parallel lines near the rit of the leaf.

PTERIS. Fructif. in linea marginalina. Invol. e margine froudis intlexo, continuo.

PTERIS. Capsules disposed in a line under the reflected edge of the liaf.

ADIANTUM. Fruct. in punctis marginalibus. Anonlucra. e margine frondis inflexo, interrupto.

ADIANTUM. Capsules forming oval spots under the reflected points of the leaves.

CYATHEA. Fruchf. sparsæa, subrotundæ, calyci apice dehiscenti insidentes.

CYATHEA. Fructifications scattered, roundish, growing out of an h:mispherical calyx.

$$
\text { * Exannulatæ. }
$$

2 Capsules without an elastic ring; in spikes.

EQUISETUM. Frons, amentacea. Semina filamentis 4 , poliniferis circumplicata.

EQUISETUM. Fructifications forming an egg-ob. long, lerminating spike. 
CRYPOGAMIA. FILICES. Equisetum. 323

OPHIOGLOSSUM. Spica disticha. Capsula immersæ.

OPHIIOG LOSSUM. Capsules united by an inveloping membrane, so as to form a is-rowed, jointed sprke.

OSMUNDA. Spica ramosa. Caps. nudæ, globosæ.

OSMIUNDA. . Capsules distinct, 2-valved, forming a bunch-like spike.

LYCOPODIUM. Capsula axillares, solitariæ, compressix.

LYCUPODIUM. Capsules axillary, solitary, naked, kidney-shaped, with 1 cell, and 2 elastic valves.

\section{FILICES.}

EQUISETUM. Smith.1102. With. 753 .

Anentum squamis peltatis, intus floriferis. Involucella bivalvia. Sem. numerosa, nuda, filamentis quatuor polliniferis circumplicata. Spike club-shaped, egg-oblong. Fructifications target-shuped, opening inwards.

E. ramis compositis arcuato-deflexis scabris, sylvai: E. Stem bearing a spike: leaves compound. cum.

BRANCHBD-VOOD-IORSE-TAIL. Moist woods and strady places, near sivulets, and in bogey ground. Newarb: Soutlivill.

Ff 
arciense. E. caulibus sterilibus undique ramosis: $\mathrm{ra}$ mis scabriusculis : fructificantibus simplicibus, vaginis distantibus late incisis.

E. Fertile stalk leafless: barren stem leafy, lying down: leaves in whirls.

CORN HORSE-TAIL. Moist cornfields. Newark; Southwell.

P. March, April.

palustre. E. caulibus fructificantibus angulatis ramosis : ramis simplicibus erectis scabriusculis.

E. Stem angular: leaves unbranched.

MARSH HORSE-TAIL. Marshy and watery places. Newark; Southwell ; Nottingham. P. June, July.

fluvia-E. caulibus sterilibus ramosis: ramis scabritale. usculis numerosissimis; fructificantibus simplicibus, vaginis approximatis setaceomultifidis.

E. Stem scored: leaves generally unbranched.

GREAT WATER HORSE-TAIT. Marshy and watery places, sides of rivers, ditches, poits, and liates. P. Miny, June.

limosum. E. caule nudiusculo ramisque lavibus, amento terminali.

E. Siem frequently naked, smooth.

SMOOTH NAKED HORSE-TAIL. In beds of ricers, near the binks; common.

P. Mlay.

hyemale. E. caule nudo scaberrimo basi subramaso, vaginis albidis basi apice que nigris, amento terminali.

E Stem naked, rough, somewhat branched at the base. 


\section{CRYPTOGAMIA. FILICES. Ophioglossum. $3^{2} 5$}

ROUGH HORSE-TAIL. SHAVE-GRASS. Marshy and watery phaces; rare. Nettleworth Green, near Mansfiell, plentifully. DeERIRG. P. July.

OPHIOGLOSSUM. Smith. 1106. Wilh. 761.

Spica disticha. Capsula bivalves, immersx, transverse dehiscentes.

Cipsules numerous, neariy globular, withone an elestic ring; uniled by a meinbrane into a spike; opening cross-ways when ripe. Seeds numerous, minute.

O. fronde ovata averia.

O. Leaf egg-shaped, veinless, bearing the spike.

CO binON ADBER'S RONGUk. Moist cold meatows and bistures. Newart and Averhan Neatows; iouthwell lieartows; Poot-sti'e Closes leading to Oxton, below hie hill. ints. preot.

r. Milay.

OSNUNDA: smiti. $110 \%$. With. 762 .

Spica ramosa. Capsule bivalves, nudx, glo. bosie.

Spiike branched. Capsules distinct, sitting, globular, 2-valued: without an elastic ring: opening either vertically or horizontally.

O. fronde pinnata basi spicifera: pinnulis lu. Luna. nulatis crenatis.

ria.

O. Stalk solitary: bunch lateral: leaf winged, solitary.

COMMON MOONWORT. Mountainous meadows and pastures, sometimes in shady woods; but not common. On the Forest iear the cateway into Edwinstow, from Retford; a grazing meadlow of Mr. Lsam's, at Sutton-unon-Trent, between Grassthorpe and Marnham.

Ff 2

P. June. 
regalis. O. fronde bipinnata apice spicifera : pinnulis cordato-lanceolatis glabris.

O. Leaf doubly winged: bunches terminating, more than doubly compound.

TOYAL MOONWORT. OSMUND ROYAI. Watery' places and boggy marshes; rare. Right hand bank on Stapleford Moor, near the lane leading froin the Sleaford Turnpite; 2 plints in the hollows nar Potter's Ilith, on the Lincoln road from Newark; and in the Carr Closes of Mr. Jacub Ordoyno, at Cod. ding

P. June, July.

LYCOPODIUM. Smith. 110g. With 756. Capsula axillares, solitariæ, bivalves, nud $x$, subréniformes, compressa.

Capsules axillary, kidney-shaped, 2-valved, elaslic; many-sceded.

clava L. Foliis sparsis filamentosis; floralibus dilas tum. tato-membranaceis, yamis floriferis inferno strigosis: apice bifidis trifidisve.

L. Leaves scattered, terminating in threads: spikes cylindrical, on fruit-stalks, in pairs.

COMMON CLUB Mross. Pry plares on mountains, heaths, and woods. Mianstield Forest. P. July.

POLYPODIUM: Smith. 1113. With. 773. Fructificationes in punctis subrotundis sparsis, non marginalibus. Involucrum nullum.

Capsules disposed in distinct circular dols on the under surface of the leaf.

* Fronde pinnatifida.

1. Leaves wing cleft.

oulgare. P. fronde pinnatifida: lobis oblongis subserratis obtusis, radice squamata. 
CRYPTOGAMIA. FILICES. Aspidium, 327

P. Lobes oblong, somewhat serrated, blunt: root scaly.

COMMO POLY PODY. On old walls, shady places, and at the roots of trees; not uncommon. Walls of the Palice, at Southisell. P. Nay, Oct.

* Fronde supradecomposita.

2. Leaf triply winged.

P. fronde ternata bipinnata patulo.deflexa; Dryoplaciniis obtusis subcrenatis, radice filifor- teris. mi.

P. Stem supporting 3-zwinged or doubly winged leaves.

TENDER THRTE-BRANCHED POLYPODY. Dry siony places; rare. Near Pleasly Forge. DEERIAG.

ASPIDIUM. Smith. 1118.

Fructiflcationes in punctis subrotundis, sparsis, non marginalibus. Involucrum umbilicatum, undique fere dehiscens.

Aspidium. Fructifications scallered in roundish dots not marginal. Involncrum umbilicaled, bursing almost all round.

\section{Fronde subbipinnata.}

Leaves winged; wings deeply wing cleft:

A. fronde bipinnata: pinnulis obtusis serratis, Filax. stipite paleaceo, involucris circinatis. mas

Polypodium Filix Mas. With. 775.

P. Leaves almost doubly winged: leafits strap. spear-shaped: lobes bluni, finely serraled, stem and mid-ribs chaffy.

$$
F\lceil 3
$$




\section{CRYPTOGAM. FILICES. Asplenium.}

MALE FERN. MALE SHIELD FFRN. Woods, heaths, slony places; common. Kdingley. H:1l.

P. June, July.

Filix. A. fronde bipinnata : pinnulis pinnatifidis serfamena. ratis muticis, rachilavi, involucris renifor. mibus.

A. Leafits strap-spear-shaped, wing-cleft, acute: stems smooth upwards.

Polypodium Filix Fæmina. With. 778.

FEMALE SHIRLD-FER N. Moist and shady marshy places, moist rocky wools; Codddington Moor; Combes Wood." P. June, July.

dilata. A fronde bipinnata: pinnulis pinnatifidis intum. ciso-scrratis spinulosis, rachi squamosa: involucro circinato.

A. Leafits deeply wing-cleft; segment oblong, blunt, serrated, fringed: clusiers of capsules in a double row.

Polypodium cristatum. With. 778 .

GREAT CRESTED SHIELD FERN. Noist roods and shady places, in a gravelly soil, and chinks of moist rocks and old walls: roots of decaying trees. St Ame's Viell. DEERING. P. June, July.

ASPLENIUM. Smith. 1126. With. 766 .

Fructif: in lineolis sparsis. Involucr. e vena lateraliter ortum ducens, interius (sive costam versus) dehiscens.

Capsules, disposed in siraight and nearly parallel lines on the under surface of the leaf

Tricho- A. fronde pinnata: pinnis ovato-subrotun manes. dis crenatis, rachi nitida subtus carinata. 
CRYPTOGAM. FILICES. Scolopenảrum. 3:9

A. Leafits nearly circular, scolloped.

COMMON MAIMBS-HAIR. SPIAEM-MOMT.

Old nalls, rocks, and shaty story phakes. Masfori

Church; Wollaton Park Halls. P. May-.-Oetober.

A. Fronde alcernatim decomposita: pinnis Rula, rhombuideo cuneiformibus patentibus apice muraerosis.

ria.

A. Leafits wedge-shaped, finely scolloped.

WALL-BUE. SPLEN-WORT WETH MADEN-HATR. Old walls, and molot creviess of rocks. Walls of Geding Church. P. Juie----Cet.

A. fronde subdeltoidea alternatim tripinnata: Adianpinnulis lanceolatis acutiusculis inciso-ser- iumratis.

A. Leaves almost triply-uinged: wings alternigrum. nate: leafits spear-shaped, cut-serrated.

BRACK MAIDEN-ISAIR.SPREY-WORT. Shady places and old walls Rock holes in Yotringham Park.

2. J tue... october.

SCOLOPENDRIUM. Shith. 1113. With.

Fructif. in lineolis sparsis, geminis interve. niis. Involuc. superficiaria, sibi invicem longitudinaliter incumbentia, satura longitudinali dehiscentia..

Fructif. in scattered doublelines, between veins. Invol. superficial, folding lengthways over one another, separating by a longitudinal suture.

S. fronde simplici cordato lingulata subtis vulgare. lavi.

S. Leaves heart-longue-shaped; very enize: stalks hairy. 
$33^{\circ}$ CRYPTOGAM. FILICES. Blechnum:

Asplenium scolopendrium. With. 766 .

COMMON HART'S T():GUF. Moist shady roclis, mouths of wella, old walls, and in the fissures of rocks. Oxton Bottons.

1. July.

BLECHNUM. Smith. 1135. With. $76_{5}$.

Fructif. in lineis longitudinalibus, continuis, costæ aljacentibus. Involucr. superficiarium, continuum, costam versus dehiscens.

Capsules forming 2 parallel lines near the rib of the leaf:

breale. $B$. fronde pinnata glabra: pinnis linearibus obtusiusculis integerrimis basi subæqualibus.

B. Barren leaves wing-cleft: fruitfu! leaves. winged, narrower; syemenis very entire.

B. Spicant. With. 765 .

NORTHERN BLECHNUM. ROUGII SPLEEN-

WORT. Groves and moist heaths. Stapleford and Langford Moors.

P. July.

PTERIS. Smith. $113^{6 .}$ With. 764 .

Fructif. in linea marginali, continua. Involucrum e margine ipsius frondis inflexo, continuum, interius dehiscens.

Capsules disposed in a line under the reflected edge of the leaf.

cquili. P. fronde supradecomposita : pinnulis lance$n a$. olatis acutiusculis : infimis pinnatifidis; superioribus minoribus.

P. Leaves more than doubly compound: leafits winged: wings spear-shaped; the lowermost wing-cleft; the upper ones small: Gr. 


\section{CRYPTOGAMIA. FILICES. Cyathea. $33^{\circ}$}

COMMON BRAKES. Heatis and Wocds; common.

P. July.

CYATHEA. Smith. 1133.

Fructif. sparsx, subrotundx, calici hemisphærico, apice dehiscenti absque operculo, insidentes.

Fructifications scattered, roundish, growing out of an hemispherical calyx, which bursts at the top without an operculum.

C. Tronde bipinnata: pinnulis pinatifidis in-fragilis. ciso-serratis, floribus sparsis, calyce lacero, rachi alata.

C. Wings spear-shaped; leafits with a few irregular leeth lowards the end: stem very slender and bristle.

Polypodiun fragile: With: 799 .

HRTTME CUP=ERR, Dry stany plares, on the

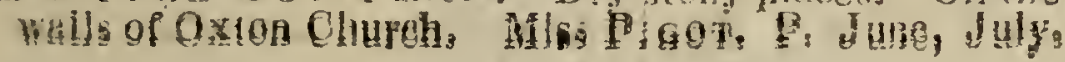

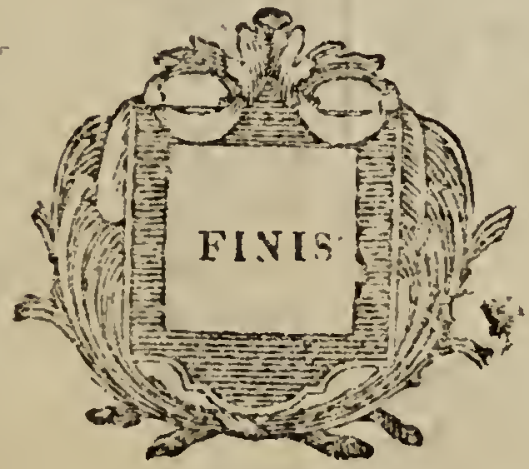

Printed by $S$. and $J$. Ridge, Nowank. 


\section{INDEX GENERUM LATINUS.}

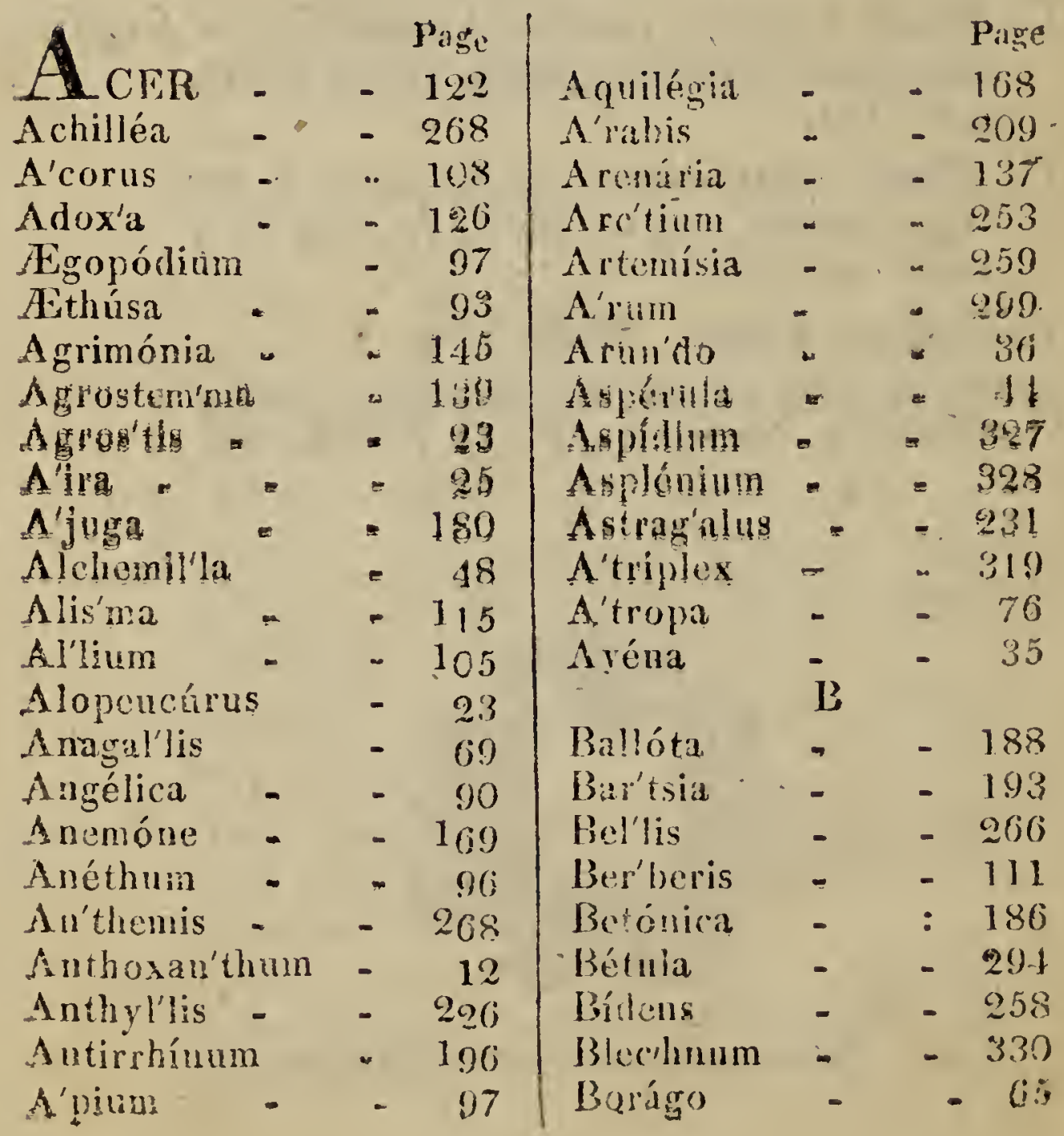




\section{INDEX GENWRUA LATINUS.}

$\begin{array}{lllr}\text { Bras'sica } & & & \text { Page } \\ \text { Brína } & - & - & 210 \\ \text { Brómus } & - & - & 30 \\ \text { Bryónia } & - & - & 33 \\ \text { Búnium } & - & - & 296 \\ \text { Bútomus } & - & - & 88 \\ & \text { C } & & \end{array}$

Callitriche .. $\quad 3$ Cal'tha - - 174

Campanula - $\quad-71$

Cardan'ine - $\quad$ - 205

Càriluus - $\quad$ - 254

Cárex - $\quad$ - 287

Carlína - $\quad-257$

Carpínus - $\quad$ - 301

Cúruin - $\quad$ - 96

Caúculis - $\quad$ - 87

Contauréa - $\quad-269$

C.rastium - - 1-10

Ceratophyllam - 297

Charophyllim - 94

Chára

- $\quad 2$

Cheliclónium - 165

Chenovódium - 82

Chirovia - - 77

Chlóra. - - 120

C'hrysan'themum - 266

Chrysosplénium - 132

Cichórimm - $\quad 253$

Cicúta - - 93

Circáa - - 7

Cistus - $\quad 167$

Clématis - - 170
Clinopódium $\quad-\quad 170$

Cochleária - - $\quad 201$

Col'chicum - - 114

Cómarum - $\quad 160$

Conímm - . 99

Convallária $\quad-108$

Convolivulus - $\quad 70$

Cony'za - - 261

Cor'nus - - 47

Corylus - - 309

Crépis _ . 251

Crócus - - 18

Cuscuta - - 55

Cyáthea - $\quad 331$

Cy'clamen - : - 67

Cynoglos'sum - $\quad 61$

Cynosúrus - $\quad 31$

D

Dac'tylis - $\quad-30$

Dalline - - 122

Daúcus - $\quad$ - 88

Diau'thus - $\quad-134$

Digitális - - 198

Dip'sacus - $\quad 42$

Drílsa - $\quad 202$

Diosera - -100

E

F'chium - $\quad-66$

Eimpet'rum - - 311

Empilóbium - 118

Equisétum - $\quad-323$

Eródium - - 21.4

Eríca - - - 121 


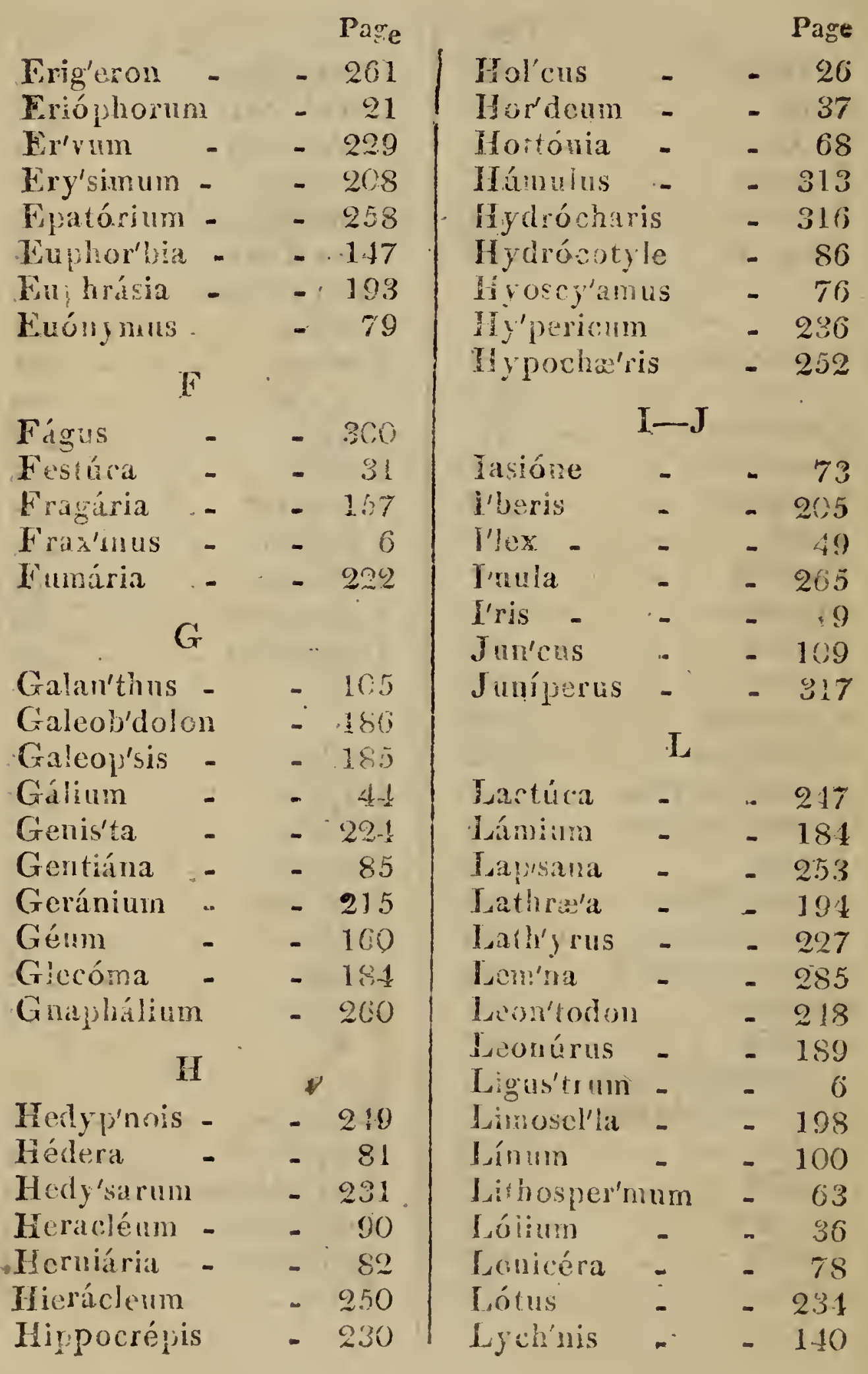




\section{INDEX GENERUM LATINUS.}

\begin{tabular}{|c|c|c|c|c|}
\hline & Page & Orig'anum & & 190 \\
\hline Lycopódium & - $\quad-326$ & Ornithógalu & & -106 \\
\hline Lycop'sis. - & - 65 & Ornithópus & & 230 \\
\hline Ly'copus - & 11 & Oroban'che & & 199 \\
\hline Lysimáchia & 68 & Or'obus & & - 227 \\
\hline Lyth'rum & 114 & Osmun'da & - & $-\quad 325$ \\
\hline $\mathrm{M}$ & & Ox'alis & & \\
\hline Mal'va & 217 & & 1 & \\
\hline Marrúbiam & - $\quad 188$ & Papáver & - & 165 \\
\hline Medicágo - & $\begin{array}{l}-235 \\
-\end{array}$ & Parictária & - & 48 \\
\hline Melampy'rum & $-\quad 194$ & Páris & & -125 \\
\hline Mélica . & 27 & Parnas'sia & & 99 \\
\hline Men'tha - & 182 & háca & & 95 \\
\hline Monyan'thes & - $\quad 63$ & Pediculáris & & -195 \\
\hline Mercuriális & - & Pep'lis & & -111 \\
\hline Mespilus - & $-\quad 152$ & Peucédanum & & 89 \\
\hline Mon'iia - & $-\quad 38$ & Phellan'drius & & 92 \\
\hline Myosótis - & - 63 & Phléum & - & 29 \\
\hline Myosúrus - & -101 & Pícris & - & -216 \\
\hline Myríca & $-\quad .913$ & inel'la. & . & 96 \\
\hline$v^{\prime}$, & -297 & Phiguir'cula. & - & 10 \\
\hline $\mathbf{N}$ & & Plantágo & & 46 \\
\hline N & & Póa - & & 28 \\
\hline arcis'sus - & $-\cdots 105$ & Polyogala & - & -223 \\
\hline Nar'dus & $-\quad 22$ & Poly'ganum. & & -123 \\
\hline Narthécium. & -107 & Polypótium & & .. 326 \\
\hline Népeta &.$\quad 181$ & Popinlus & - & $-\quad 31 t$ \\
\hline Nymphw'a & -106 & Potamogéto: & & 49 \\
\hline 0 & & Potentil'la & & -158 \\
\hline$=0$ & 12 & Potérium & - & -209 \\
\hline Oenanthe - & -.92 & Prenan'thes. & & -218 \\
\hline Onónis & $-\quad 225$ & Prímata & - & 66 \\
\hline Onopor'dum & -256 & Prunelya & - & $-19 \mathcal{Z}^{\prime}$ \\
\hline Ophioglos'sum & $-\quad 3 \% 5$ & Prínus & & -151 \\
\hline O'phrys & -275 & Ptóris & - & - 330 \\
\hline O. $i^{\prime \prime}$ chis & .272 & Py'rus- & & $=153$ \\
\hline
\end{tabular}




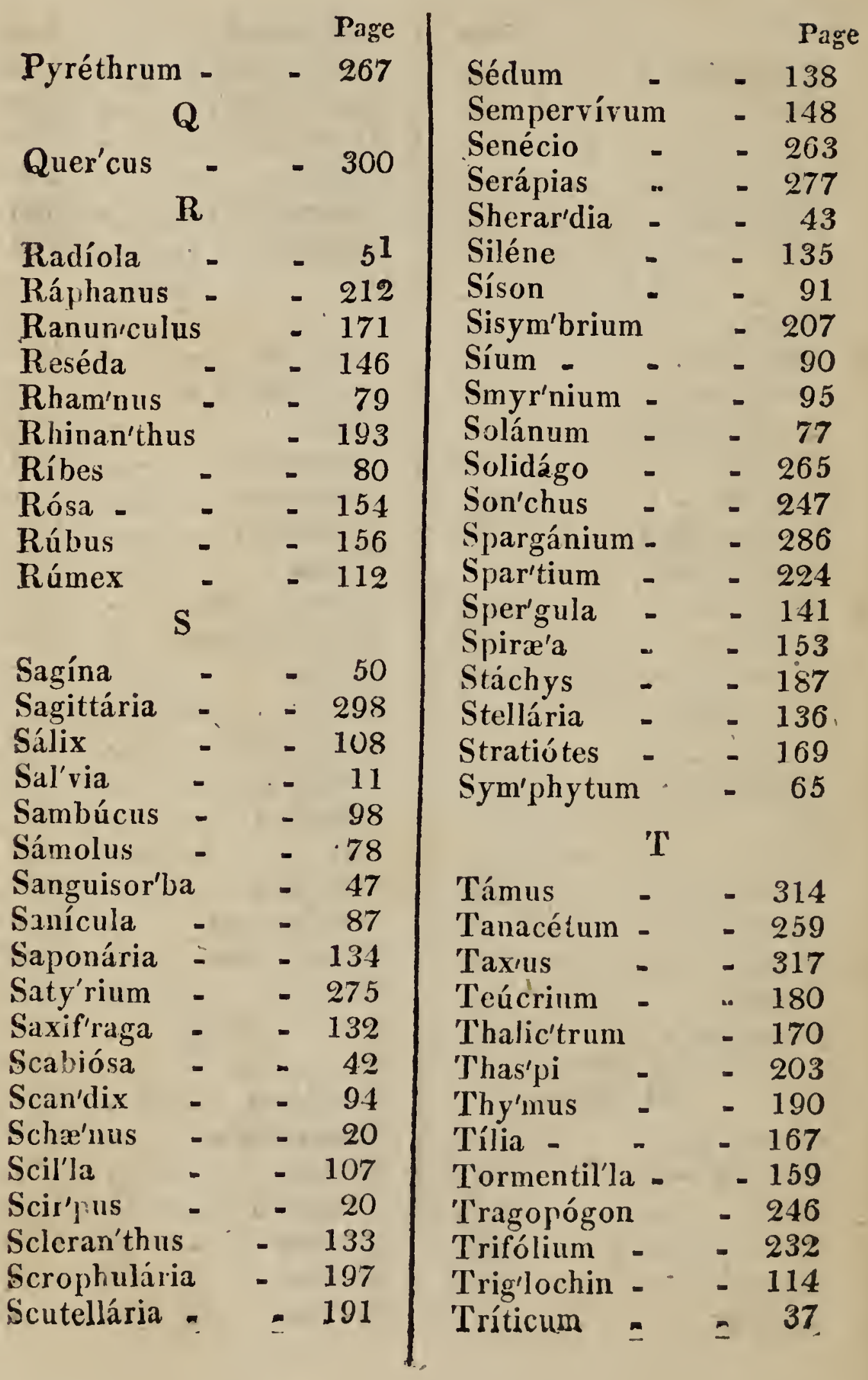




\section{INDEX GENERUM LATINUS.}

\begin{tabular}{|c|c|c|c|c|c|}
\hline & & Page & & & Page \\
\hline Turrítis & $\cdots$ & -210 & Valcriána & - & 17 \\
\hline 'Tussilágo & - & -262 & Verbas'cum & .. & 75 \\
\hline Ty'pha & - & -286 & Verbéna & - & 181 \\
\hline & & & Verónica & - & 7 \\
\hline U'lex & & 225 & Vibur'num & - & 98 \\
\hline Ui'mus & & 84 & Vi'cia & & 228 \\
\hline Urtíca & - & $\begin{array}{l}-295 \\
-\end{array}$ & in'ca & - & 81 \\
\hline Utriculária & & $-\quad 10$ & $\begin{array}{l}\text { V'ola } \\
\text { V'is'cum }\end{array}$ & - & $\begin{array}{r}73 \\
910\end{array}$ \\
\hline & & & & & \\
\hline cci'nium & & 120 & & & \\
\hline
\end{tabular}




\section{ENGLISH INDEX.}

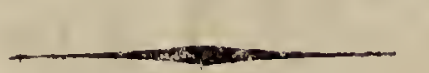

A DDFR's tongue 325 Agrimony - $\quad 146$ A.lder - - $\quad 295$ Alehoof - - 181 Alexanders - $\quad-95$ Allseed - .. 51 Alkanet - - 64 Angelica - $\quad$ - 99 Apple-tree - $\quad$ - $\mathbf{1 5 3}$ Archangel - $\quad 185$ Arrow-giass Arrow-head

- 114 Arsmart - . 124 Ash-tree - - 6 -mountain - 153 Asp - - $\quad-315$ Aspen-tree - 315 Asphodel - $\quad 108$ Avens - $\quad 160$ Abele-tree - 315 B
Barley-wall $\quad-\quad 37$ Barberry - 11 Bartsia - $\quad-.193$ Basil - $\quad 189$

Buenstraw - - 45 Beech-tree - - 301 Bell-flower - 71-79 Betony yauls - $8-187$ Bilberry - 120 Biudweed - 70-71-125 Birch - - 294 Bird's-foot 230 Bird's-rest - 276 Bistort - - 121 Bitter-sweet - 77 Bladder-snout - 1:-11 Black-crow - 312 Black-thorn - 152 Blinks - - , 38 Bitie-bottle - 270 Borage - 65 Box-tree - 295 Brakes - 331 Bramble - 157 Briony - 297-314 Briar wild - $\quad 156$ - swect - 156 Brooklime $\quad-\quad 8$ Brook-weed 78 
ENGLISH INDEX.

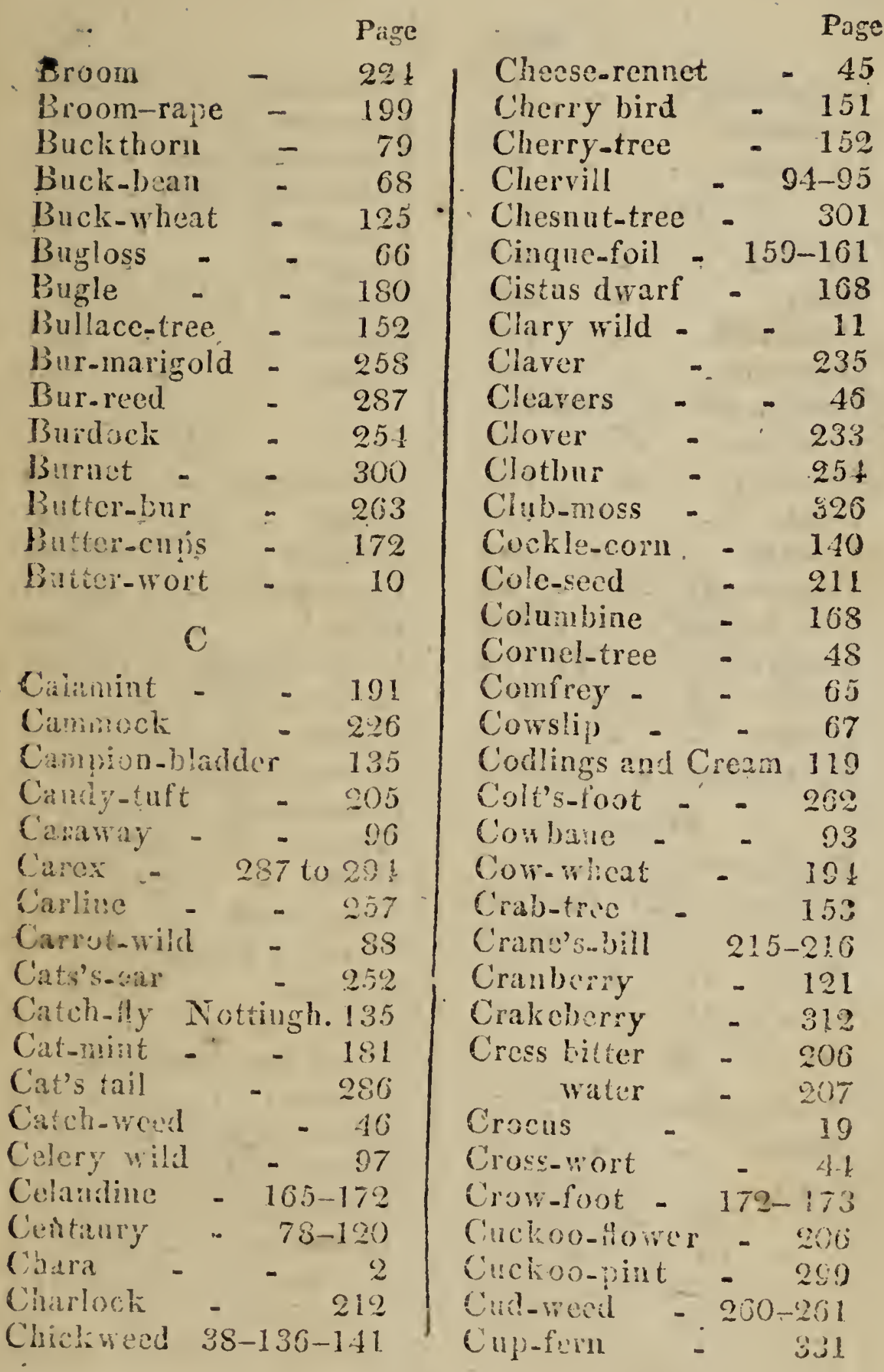


Page

Page

Gypsie-wort - $11 \mid$ Flea-bane - 262.265 Gurrants - $\quad 80$

Cyclamen - $\quad 67$

Flixweed - - 208

Flower..de-lace - 20

Flowering Rush - 128

D

Daffodil - - 105

Daisy - - 266

Dandelion - 219

Danewort $\quad$ - $\quad 99$

Dead-nuttle - 18t-186

Deril's-bit - 43

Dewberry - 157

Dock - 112-113

Dodder - - 85

Dog-wool - -48

Dove's-foot - -216

Drop-wort . $\quad 02-154$

Duck-weed - 285

Dwale - - 76

Dyer's-wee I - 146-224

$$
\text { E } \Rightarrow
$$

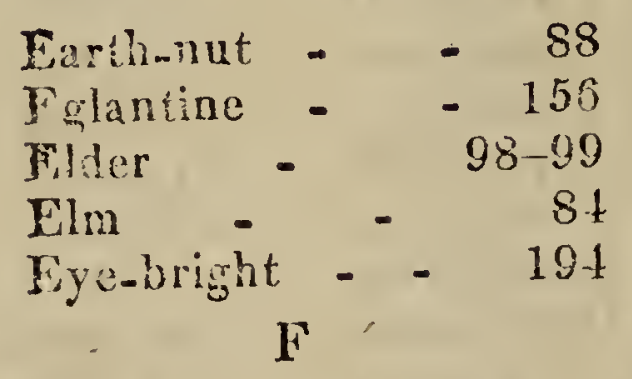

Trather-foil - - 68

Fennel - - 96

Firu - - 328

Hevefew - 267-268

Fimport - - 198

Fir-tree - - 509

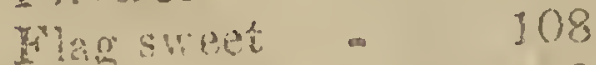

Frax puratizg - 100

Fluellin - - 198

Foxglore - - 196

Frogbit - - 317

Fumitory - $\quad 223$

Furze - - 225

\section{G}

Gale sweet - 313

Garlic - - 106

Gentian - 85-86

Germander - $\quad 9-180$

Gill - - 184

Goat's-beard - 246

Golden rod - 265

Goose-grass - 46

Goose-tongue $\quad-\quad 269$

Gooseberry - 81

Goose-foot 82-83-84

Gorse - . - 225

Gout-weed - 98

Crass of Parmassus 100

Crasses - 22 to 35

Gray-mill - 61

Grass Swowt scented

vernal - - 12

Crsass-ioly - 145

Gresnwaed - 224

Gromweil - 64

Grounisel - 263-261

Croundiry - 181

Girey irillit - 61

- Cuevider luse - 98 
Page

Iliatebell - 107

IIracinth wild - $10 \%$

Hart's-tongue - 330

Hawksbeard - 252

Hawkweed 250-251-252

Hawthorn - 153

Irazel - 81-302

Heart's-ease - 71

Finth - 121-122

Hotionea - 227

Hodypnois - $210-250$

Hoilebone 277-278

ilimlonk - 89-93

11.mp-1srimony 258

Jremp-Velte 185-180

I!nbilic . . 76

I1mbit.- - 10-185

Hep-tive - 150

Herb-twopence - 69

llerb-gerrard - 98

llerb-bennet - 160

Herb-Paris - 126

Herb-Robert - 210

ligh-taper - 75

Ilog-wed - 90

Ilolly-tree - 49

Honienort - 92

Hop - - 314

Horn.wort - 297

IIorn-beam - 302

Houry-suckle - 79

Hore-hound 11-1S9

IIorse-radish - 204

Horse-tail - 323.321

Hounds-tongue - 65

House-leer - 148

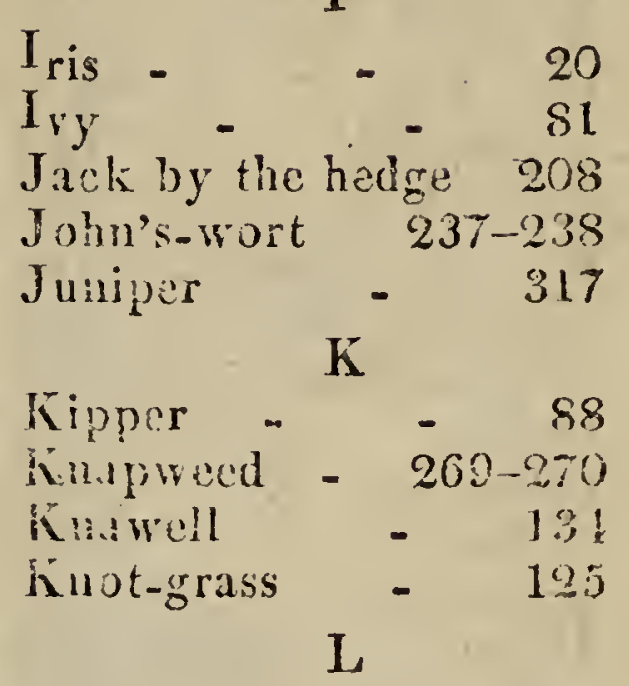

Ialles'finirer - 225

LAlies'-mantle - 49

Ladies'-smouk - $20 \%$

Lathyrus - 227-228

I sanrel spurge 129

Lettuce - - 18-218

Lilly of the valley $10 \mathrm{~s}$

Linden-tree - 167

Iime-tree - 167

Loose-strife - 09-115

louse-wort - 195

Incerne - 235

luligwort - 251

M

Maple - $\quad$ - 123

Madder - - 43

Maiden_hair - 329

Mallow - 217-218

Marjoram - $\quad-120$

Marygold corn - 267 
Page

Marigold marsh - 174

biay .. - 153

Nay-lilly - 108

May-weel - 263

Meadow-lychnis - 140

Mcadow-sweet - 151

Meadow-rue - 170

Meadow-vetchling 228

Miedick - $\quad 235$

Hercury - 316

Melilot - - 232

Mignonette .. 147

Mil-foil - 10-260-208

Milk-retch - 232

Missel toe

Mint

- $\quad 313$

$182-183$

Mill-wort - 223

Money-wort - 60

Moon-berins - 121

Moss-berries - 121

Aroschatell

Moon-wort

Mother-wort

Mouse-tail

Mudwort

Mugweed

Augwort

Mullain

Mustard

126

325.326

- 189

- 101

- 109

$-41$

- 200

75

- - 212

Nyrtle Dutch - 313

$$
\mathrm{N}
$$

Navew

211

Neelle green-weed

225

Nipple-wort
Nep

Netie - - 186-206

Nightshade - $7-76-77$

Nut-tree - - 302

$\mathrm{O}$

Oak - - 300

One-berry - - 126

Ophrys - 276.277

Orach - - 320

Orchis $272-273-271-275$

Orabis - - 227

Osier - . $\$ 11$

Osmund-royal - 326

Oxlip - $\quad 67$

Ox-rye - - -286

Ox-tumgur - - 216

$P$

Parsley - S8-0.;-95

Pasncp - 80-91-02-15

Pausy - - 7t

Par-tree - 153

Pearl-wort - $5 !$

Pa crerlasting - 228

Pellitory of t.e vall 18

Penny-crass - 20s

Pimy-royal - 183

Penny-wort - $\quad-86$

Periwintle - 81-8:

Persicaria - 121

Pitty-whin - 225

Pignat -. - 88

Pilewort - 172

Pink - - 134

Plantain - 46-17-115 
Prige

Page

Peter"s St. wort - 237

Plowman's Sulkenardeg!

Polypody - $\quad 3 \% 7$

Poplar - - 315

Poppy - - 166

Pond-weed - 49-50

Prickirood - 80

Jibn - - 6

Pimmose - 67

Print - - 6

Privet - 6

Purslane - 112

Pinpermel 69-70-78

Q

Quinkuntros - 153

I

\begin{tabular}{|c|c|c|c|}
\hline Ixlish & 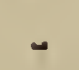 & & 212 \\
\hline lignoit & & & 205 \\
\hline IR 1 irgand-I & sti & & 110 \\
\hline Ramisons & & - & 106 \\
\hline leape & - & - & $2 ! 1$ \\
\hline lasplover & & - & 157 \\
\hline Roed & - & - & 36 \\
\hline Ravima & & - & 286 \\
\hline Rest-har & Jit & - & 220 \\
\hline liacket & - & & -207 \\
\hline Rose & - & & 1 \\
\hline
\end{tabular}

Rippture-wort - 82

Rush - 20-21-100-110

S

$\begin{array}{lr}\text { Sarron } & - \\ \text { Sage - } & 115 \\ \text { Sallarl corn } & 11-180 \\ & -185\end{array}$

S.How - - 310

Gaul-ront - 137-13s

Saint-foin - - 231

Sanicle - 10-87

Gatyrion - 275

Sulice-alone - 208

Saxifrage 89-97-132-133

Scabious - - 43

Scull-cap - - 192

Scurry-grass - 204

Siclf-heal - - 192

Septfoil - . 150

Shareagrass - 325

Shep'B-8cabious - 73

Sheep'robit - 7 :

Shephcrt'-needle - $9 t$

Shopherd"solurse - 201 Shomrita - 43

Simuson - - 263

Sloc-trec - - 152

Ginallage • • 97

minke-weed - 121

frap-dragon 190-197

Show-drop - 105

Sncezcivor - 209

Sorrel - - 111

Sow-thistle - 217

Sicarwort $\quad 171$

Sued we!l - 7-8-9-11

suindi-tice $\quad 80$

Sijlcen-wort - $329-330$

spurge • 117-118

Spuny . 142

Stanort. . 3

Star of Bathlohen . 107

Surgrass ? ? 


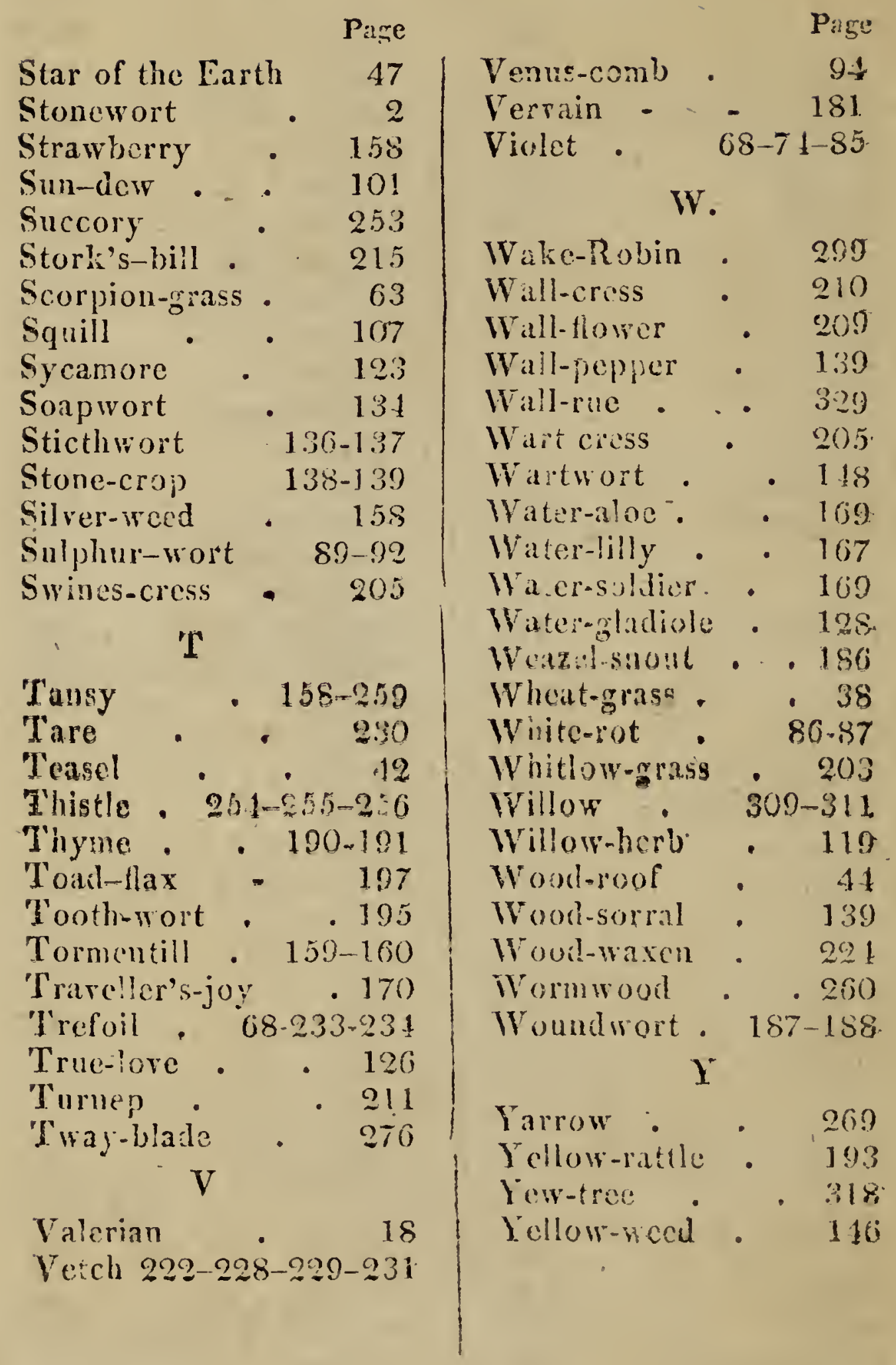





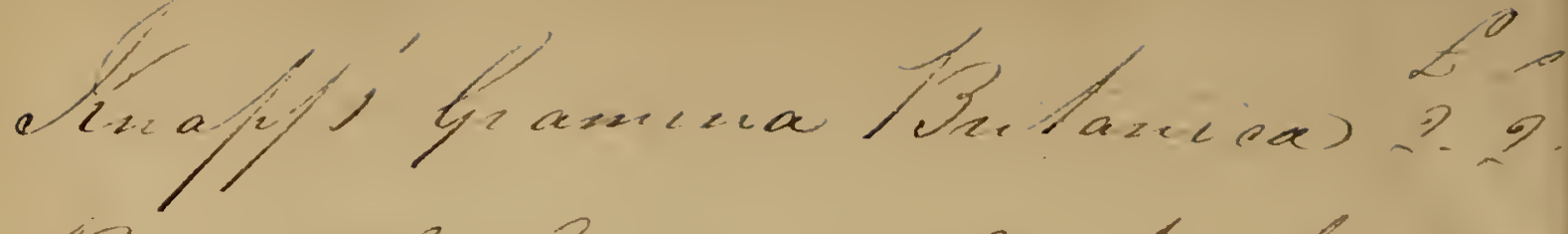

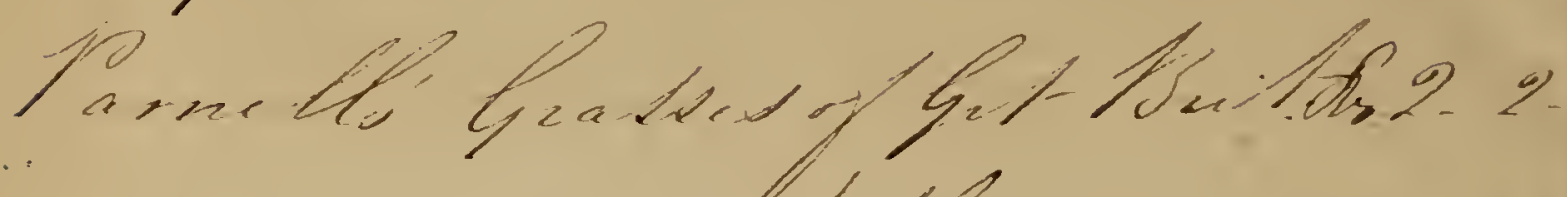

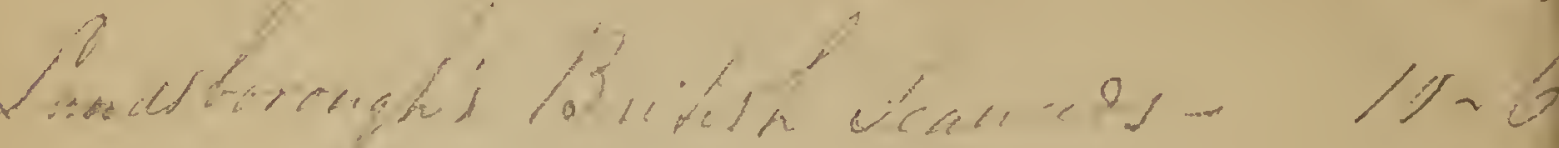




$3 x$
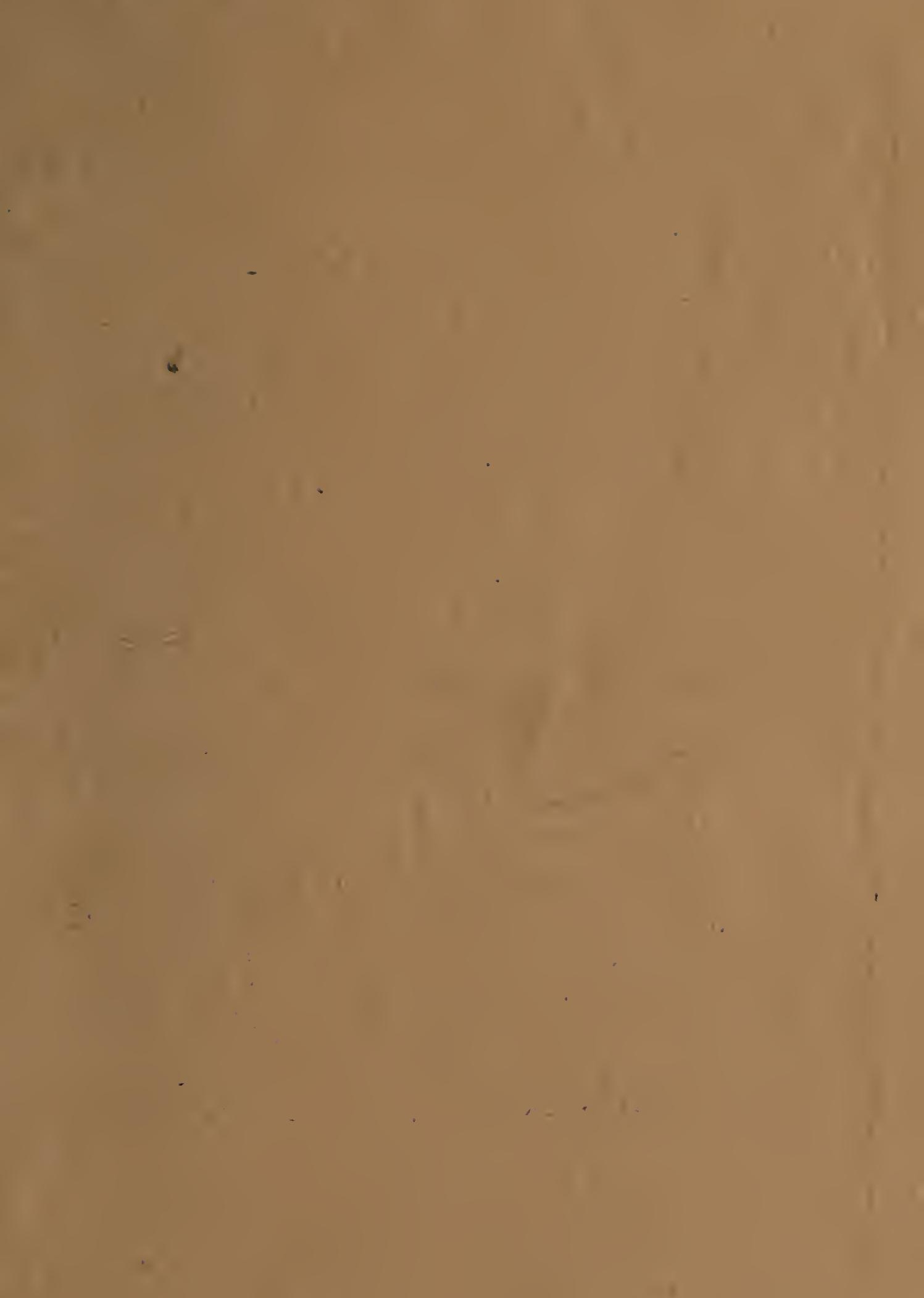

a n n

21

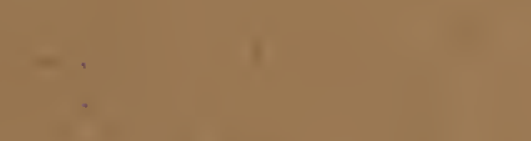


